Historic, Archive Document

Do not assume content reflects current scientific knowledge, policies, or practices. 



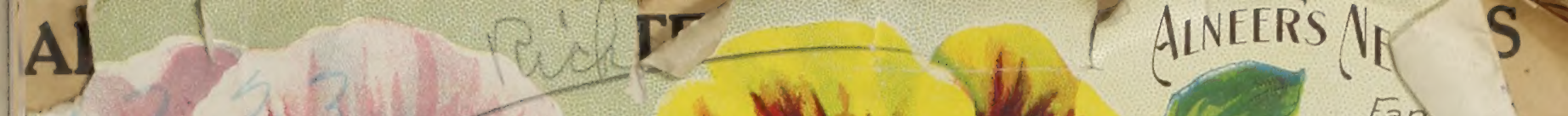

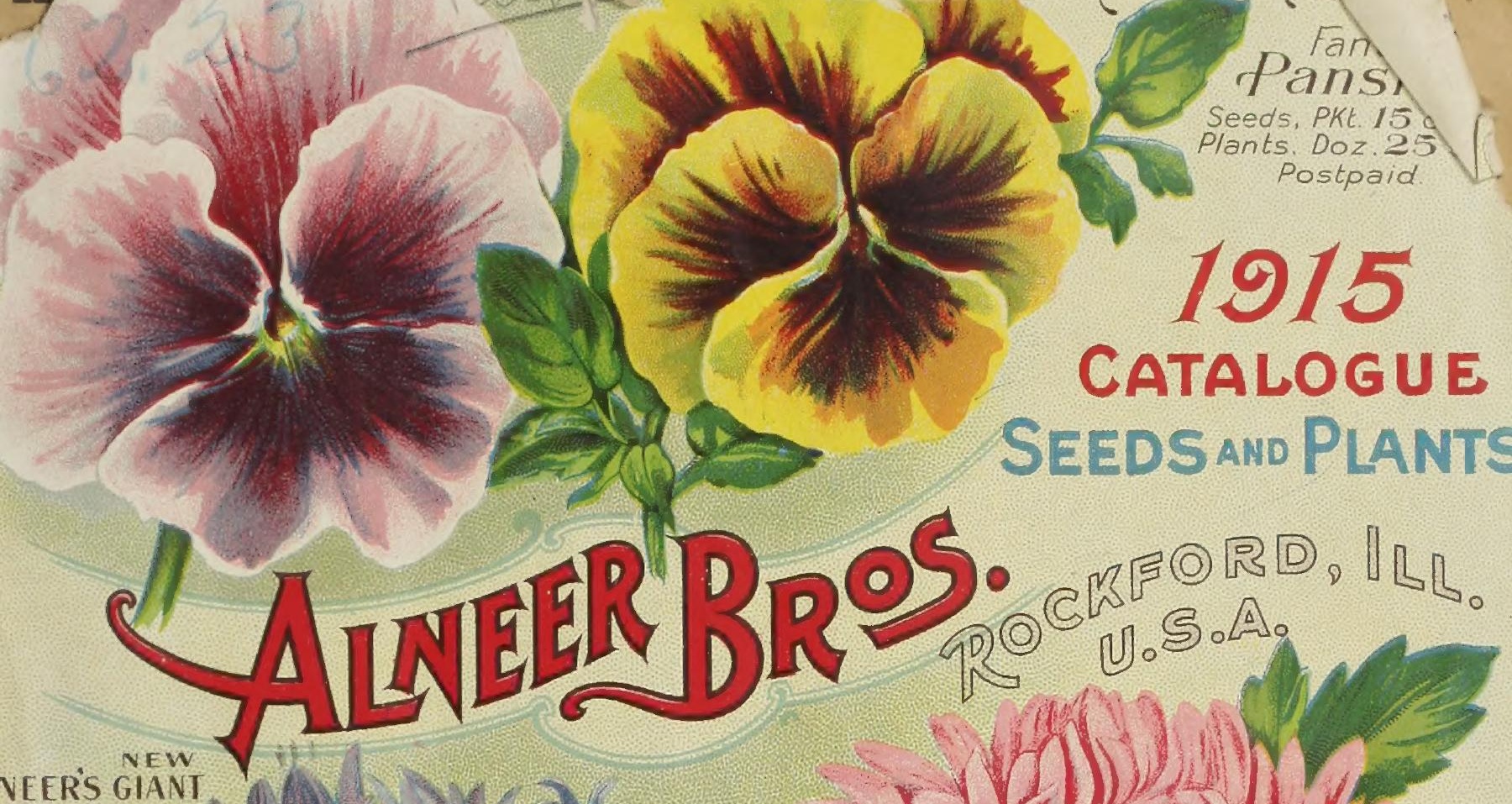
LNEER'S GIANT

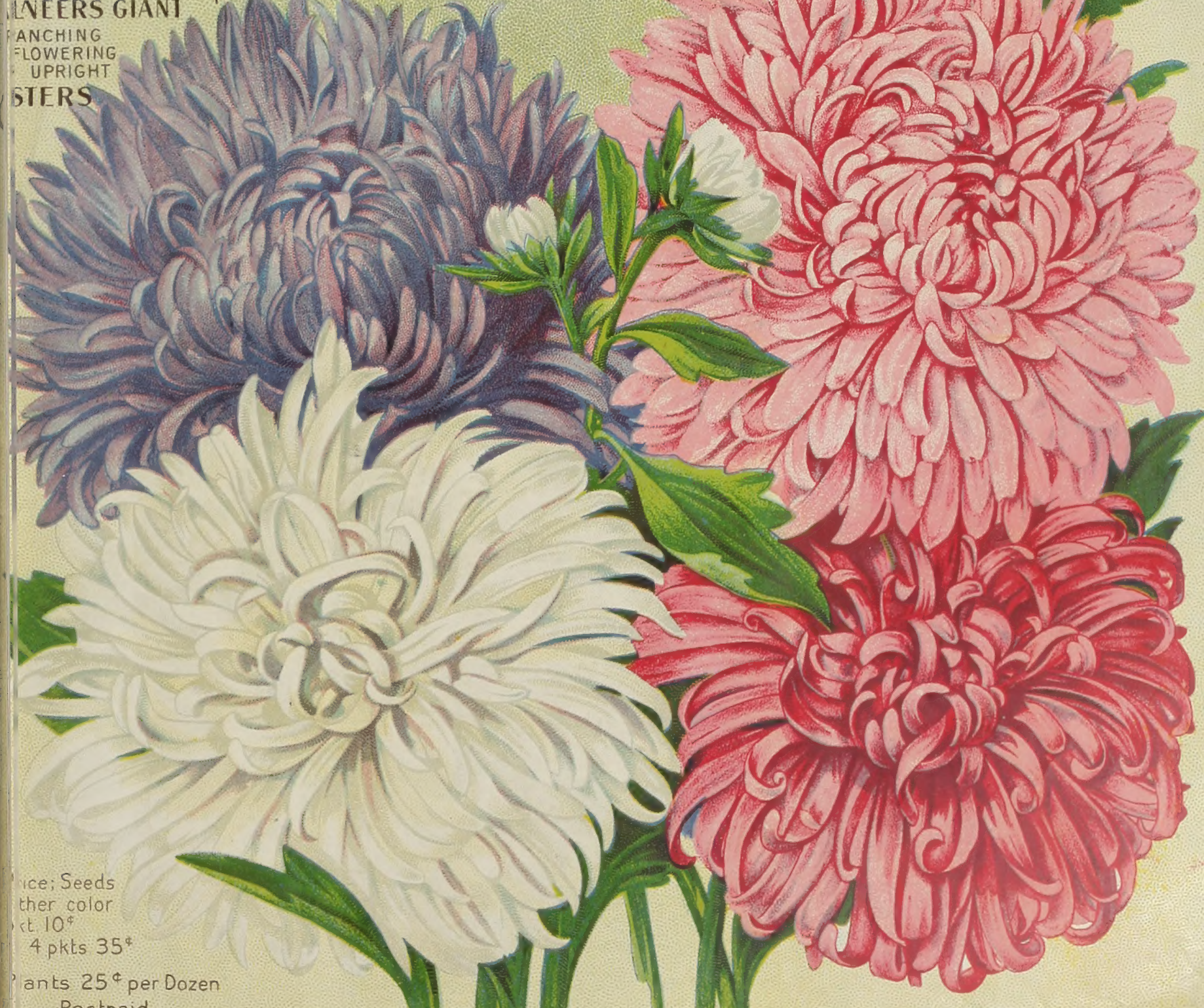




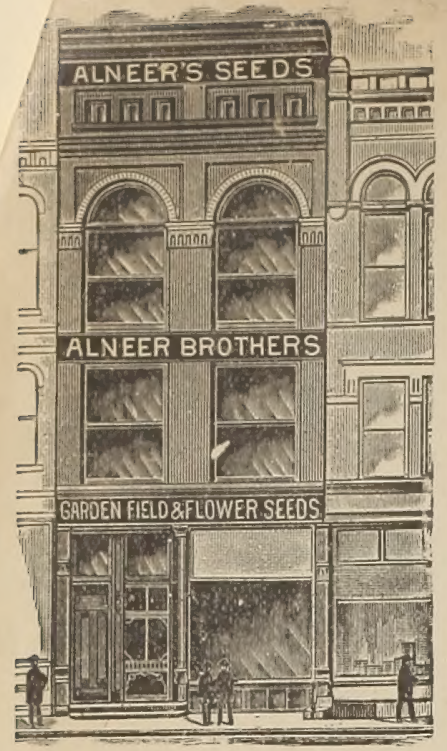

\section{Club Orders}

a Club

Positively, these

club rates.

Seeds Given Away, or Extras $\begin{gathered}\text { Every year we distribute } \\ \text { free to }\end{gathered}$ quantities of secd packets of choice and rare sorts. The larger the order as thrown in as a rule, exceptions Our Packets

What We Warrant
Friends and Patrons: A Happy New Year to you all! Again at the dawn of a New Year we send greeting to our friends and patrons, together with oun New Seed Book for 1915 of New and Reliable Seeds. We thank you all for very liberal orders given us in the past.

We greatly appreciate and want your orders. Plant Alneer's Reliable Seeds to be assured of large and bountiful crops. We have the finest and most select stock of seeds in the world, and sell them at prices that are right; no better seeds can be had at any price. We ask you to compare prices with others you may get, and by doing so you will find it to your advantage to buy from us; we save you money. Our motto is: Best Seeds Only. We have harvested a big bountiful crop this year of very best quality seeds and have placed prices very low for these fine seeds-come early and get your supply.

Thanking our friends and patrons for their kindness and liberal orders in the past, we solicit a continuance of the same. Send in your orders as early as possible, and induce your neighbors and friends to join their orders with yours, and all send for Alneer's Reliable High Grade Tested Seeds.

Yours very truly,

ALNEER BROTHERS.

\section{To All Planters of Seeds:}

We are highly gratified and thankful to our 80,000 patrons and friends for their liberal help and encouragement in our endeavor to produce and distribute high grade live seeds. We have been working at seed growing and seed selling for forty-four years, therefore, we feel sure that we KNOW SEEDS pretty thoroughly. We were determined from the start to grow and sell only high quality seeds and the fact that our customers "stick" to us and recommend thousands of new ones every year proves how well we have succeeded. Quality and again quality is our watchword.

fail no

Our Prices

Seeds, Bulbs and Plants Free by Mail (Parcels Post)

Market Gardeners and Truckers, send for Wholesale Catalogue

WE CAN SAVE YOU MONEY seeds by the $1 / 8$ bushel, (n)

列 How to Send Money by money must accompany the order, and can be sent safely We disclaim all responsibility when remit Name and Address Please remember to write your Name, Postoffice, County and State distinctly as possible especially the name, 2lso the nearest ExAddress All Letters and Make All Money Orders and Drafts Payable to ALNEER BROTHERS, Seedsmen 116 Kishwaukee Street, Rockford, Ilinois

CHOICE FLOWER 12 SEED PACKETS FOR 25 CENTS

$\begin{array}{lll}\text { Aster } & \text { Poppy } & \text { Pansy } \\ \text { Pink } & \text { Balsam } & \text { Mignonette } \\ \text { Cypress Vine } & \text { Phlox } & \text { Candytuft } \\ \text { Sweet Peas } & \text { Petunia } & \text { Ziscia }\end{array}$

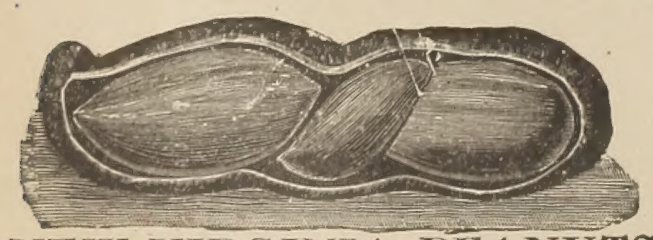

NEW VIRGINIA PEANUTS.

The Peanut$$
\begin{aligned}
& \text { quir } \\
& \text { tion. }
\end{aligned}
$$$$
\text { tim }
$$

\section{"Blue Ribbon" Vegetable Seed Collection}

\section{Packets Best Standard Sorts Postpaid, OnJy 50 Cents}

Eeans-Golden Wax Dwarf.
Bee-Lentz Early Blood Turnip.
Cabbage-All Seasons.
Celery-New Giant Pascal.
Eweet Corn-None Such.
Carrot-Alneer's Intermediate.
Cueumber-Green Prolific.
Lettuce-Farly Prize Head.
Muskmelon-Paul Rose.
Watermelon-Kolb's Gem.

Onion-Red Wethersfleld.

Onion-Yellow Danvers,

Parsnip-New Maltese

Radish-New Fire Ball.

Spinach-Bloomsdale Sayoy Leaf.

Squash-Summer Crookneck.

Squash-Hubbard.

Tomato-Royal Red.
Turnip-Purple Top Munich. 
ALNEER'S SELECTED VEGETABLE SEEDS

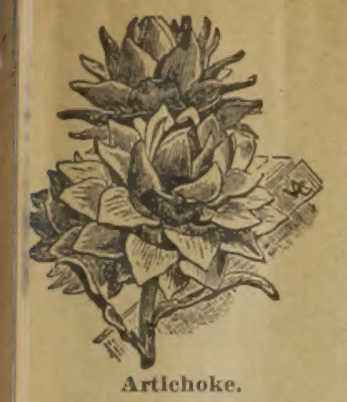

\section{Artichoke}

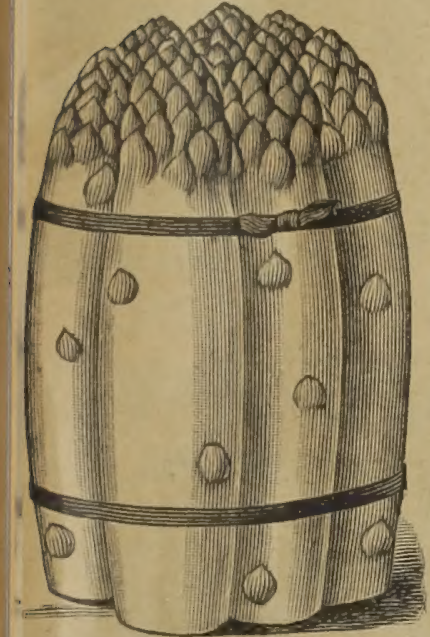

ASPARAGUS

Sow seeds early in the spring in well prepared ich ground, in rows a foot apart. Set the plants sut for a permanent bed the succeeding spring, n rows two by three feet, in very highly en-

Columbian Mammoth White.-A fine new variety, wonderfully productive and robust. The white color is of great advantage. Has been thoroughiy tried and is considered the best by all ib. $50 \mathrm{c}$.

Palmetto.-New, early and very large. The best and largest in cultivation and an enormous $25 \mathrm{c}, 1 \mathrm{~b}, 40 \mathrm{c}$.

Conover's Colossal. - The old standard sort, very

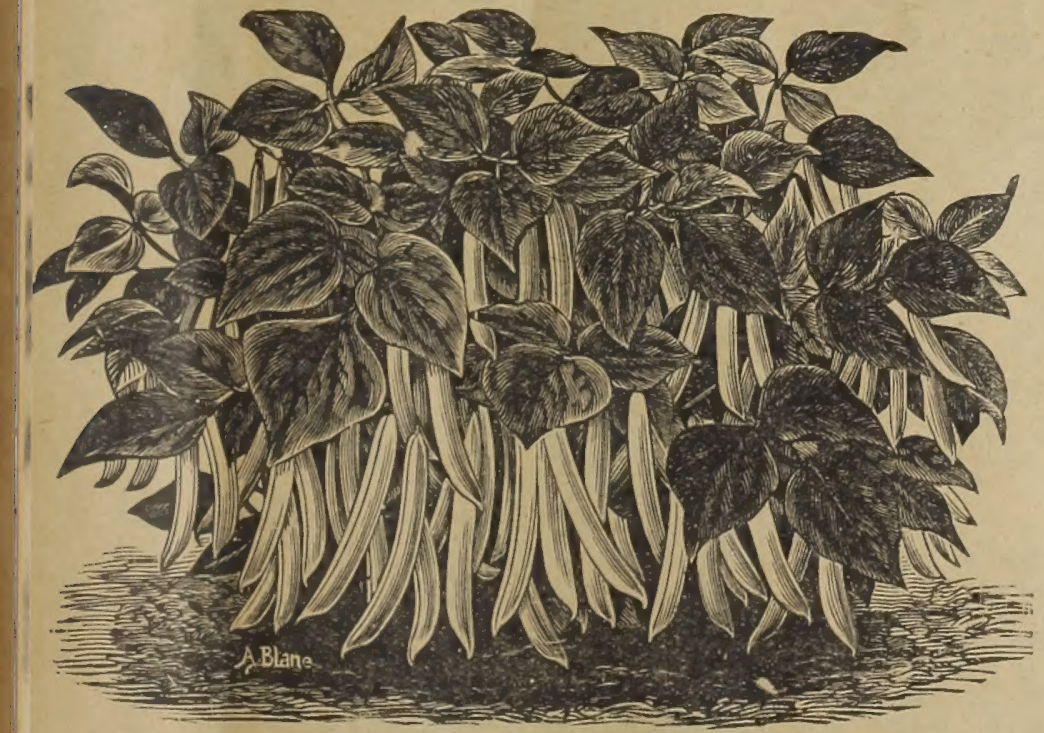

Alneer's Rust-Proof Golden Wax Dwarf Beans.

parent, yellow pods: fine
$1 / 8$ bu. $900,1 / 4$ bu. $\$ 1.75$. 5e, $1 / 2$ pt. $8 \mathrm{e}, \mathrm{pt}$
$\$ 2.60$, bu. $\$ 5.00$.
BEANS---Dwarf or Bush

The beans are very sensitve to frost and cold and should not

row. Our packets are full size and large as usual.

Prolific or Improved German Black Wax Dwarf.-Wa

Searlet Flageolet Wax Dwarf.-A splendid early variety, with long golden waxy stringless pod
qt. $38 \mathrm{c}, 1 / 8$ bu. $90 \mathrm{c}, 1 / \mathrm{s}$ bu. $\$ 1.75$.

Early Mohawk. - A good early green podded variety.

Improved Extra Farly Red Valentine,-Very early and one of the best green podded sorts; continuous in the green state
longer than most varieties. Pkt. 5c, $1 / 1 / \mathrm{pt}, 10 \mathrm{c}$, pt. 15e, qt. $30 \mathrm{c}, 1 / 3$ bu. $70 \mathrm{c}, 1 / 4$ bu. $\$ 1.35,1 / 2$ bu. $\$ 2.65$, bu. $\$ 5.25$.

Best of All.-A new valuable medium early variety, bears of fine fly $1 / 2$ pt. 10c, pt. 15c, qt. 30 e, $1 / 3$ bu. $70 \mathrm{c}, 1 / 4$ bu. $\$ 1.35,1 / 2$ bu, $\$ 2.60$.

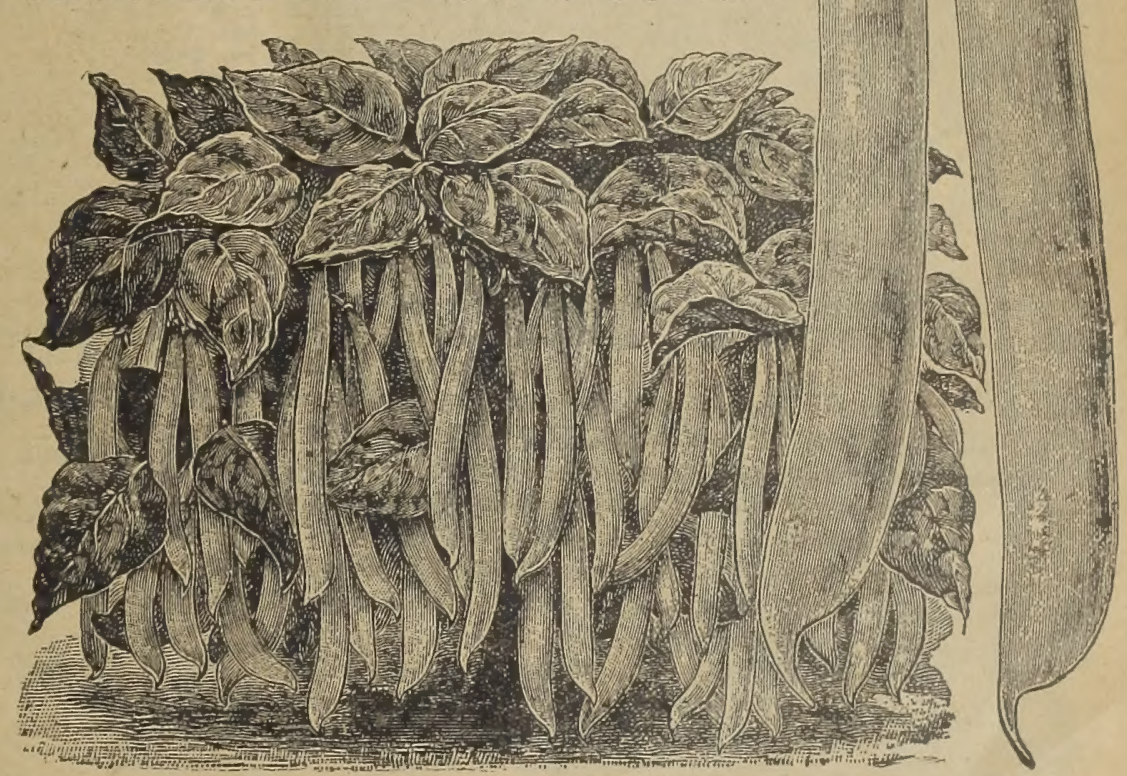

Eureka Ever-Bearing Wax Beans.

Eureka Ever-Bearing Wax is the most valuable dwarf wax

$1 / 4$ bu. $\$ 1.90$.

New Davis Wax Dwarf.-Pods waxy white, long, straight

ductive. Compact, upright growth. Pkt

Golden Wax Dwarf.-

10e, pt. 18

in tenderness and richness or flavor.

20c, qt. 35 c, $1 / 8$ bu. $90 \mathrm{c}, 1 / 4$ bu. $\$ 1.75$,

REMEMBER: Our packets are large, well filled with the best seeds that grow. 


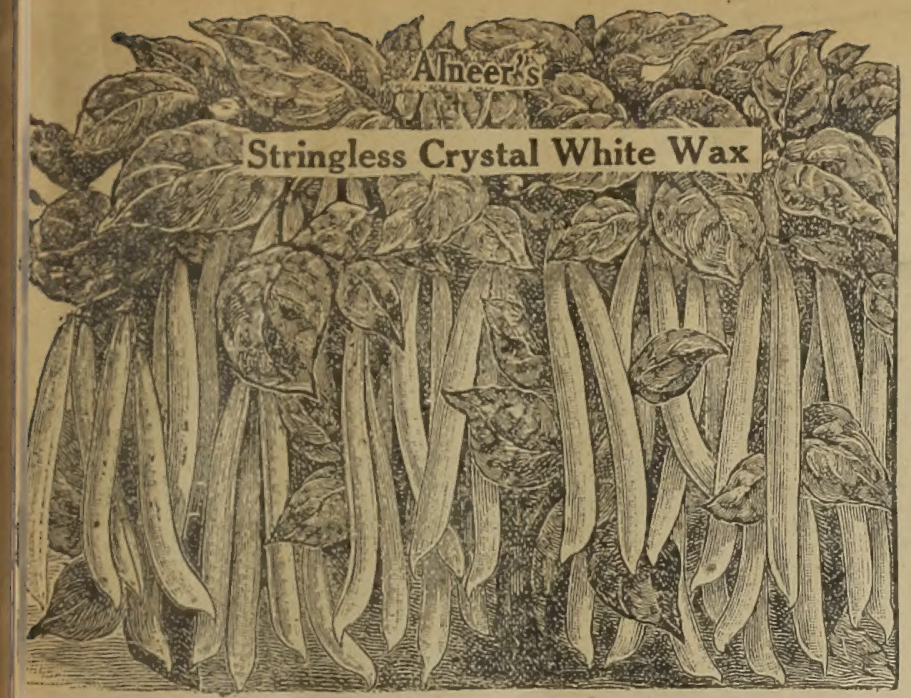

Nlneer's Crystal White Wax.-An exceptionally valuable new bean. Briefiy des

abundance and are very uniform in size and colo 5c, $1 / 2$ pt. 10c, pt. 20c, qt. 35e, 1/8 bu, 90e, $1 / / 4$ bu. $\$ 1.75$.
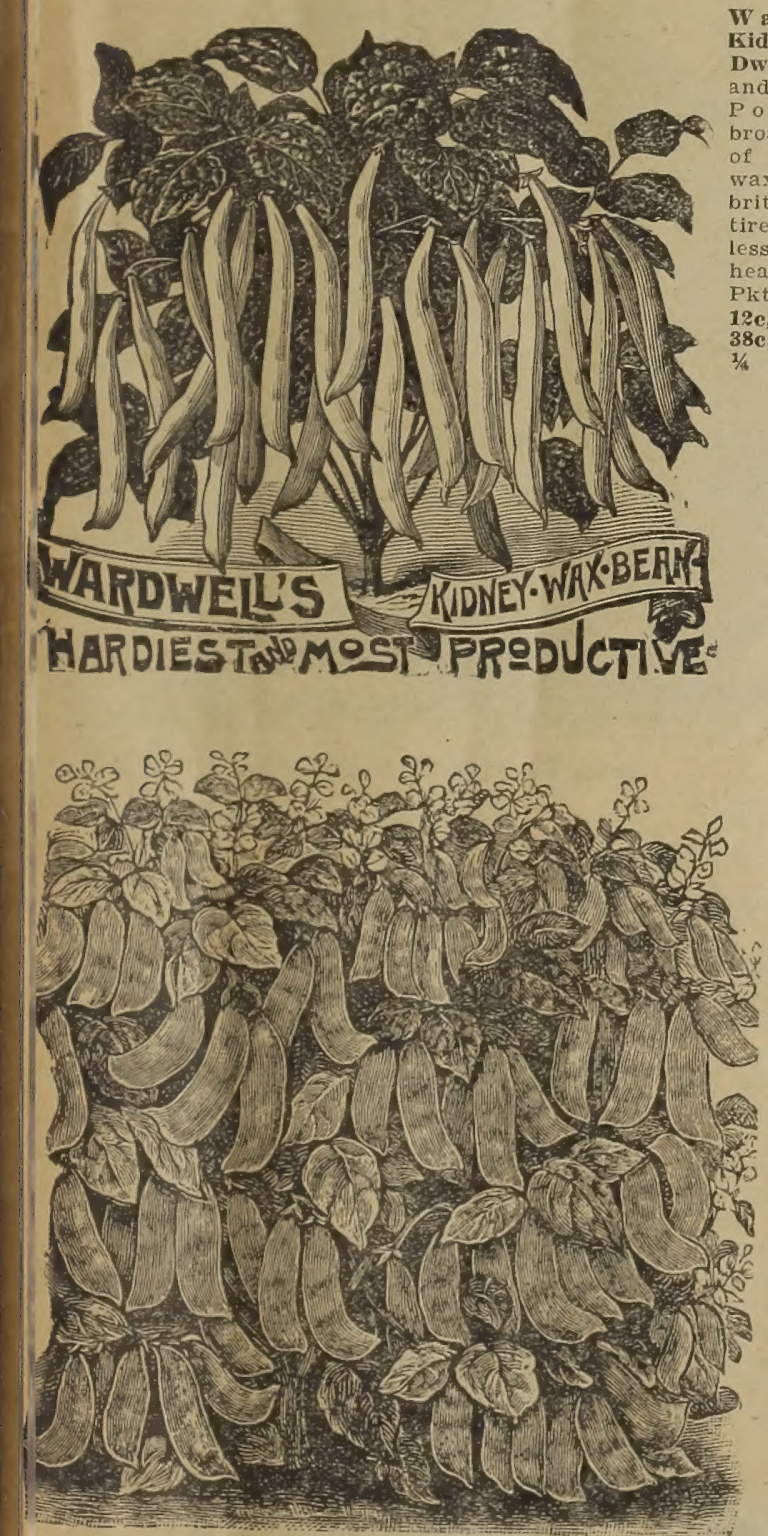

Dwarf or Busls Lima Beans.

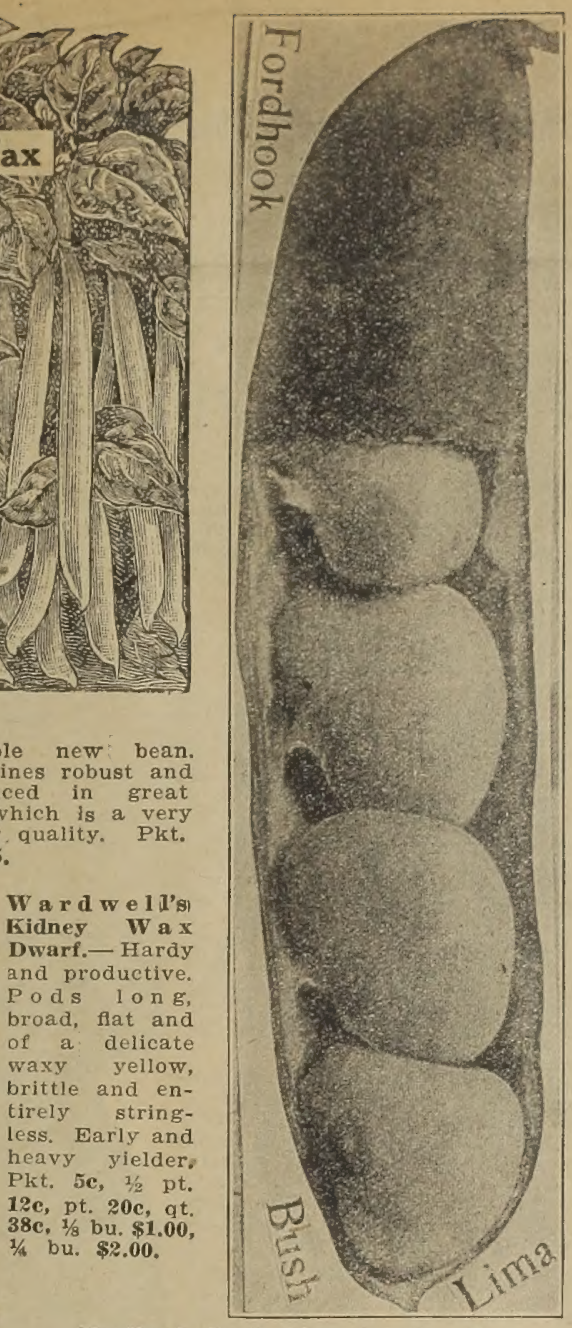

\section{BEANS}
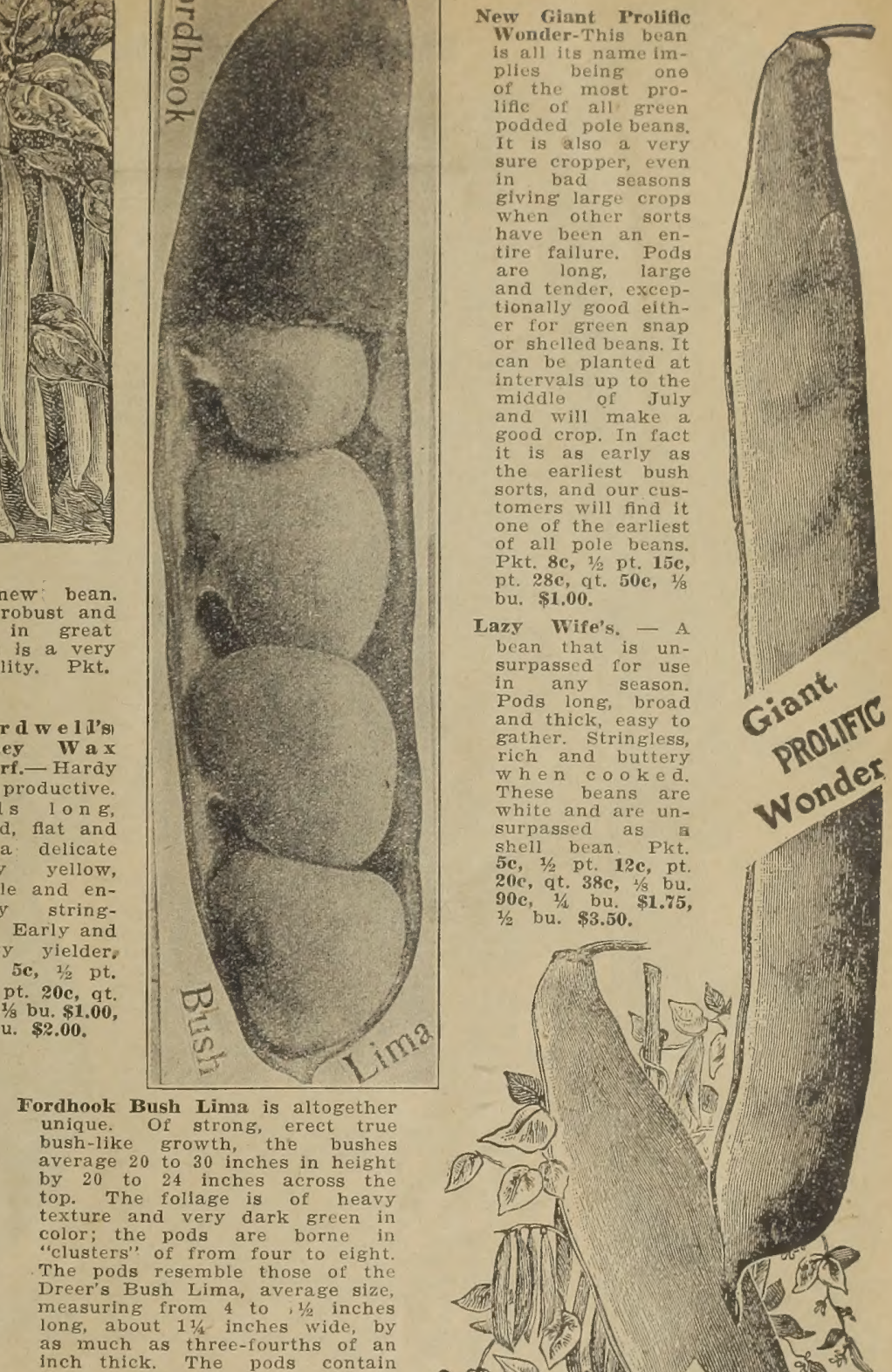

three to five large beans with an
average of four. Pkt. 5e, 1/2 pt.

Burpee's Bush Lima.-Is a perfect

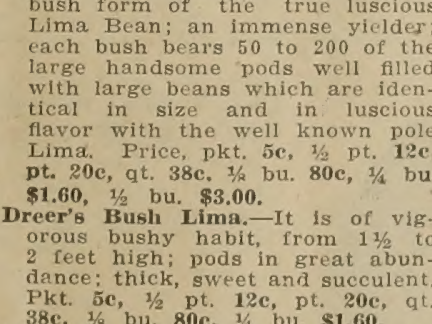

$38 \mathrm{c}, 1 / 8$ bu. $80 \mathrm{c}, 1 / 4$ bu. $\$ 1.60$.

Henderson's New Bush Lima.-The

Henderson's New Bush Lima
grows without the aid of stakes

form from 15 to 18 inches high.

and produces enormous crops of

$80 \mathrm{c}, 1 / \mathrm{s}$ bu. $\$ 1.60,1 / 2$ bu. $\$ 3.00$.

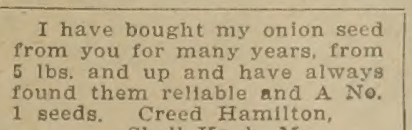
(19) की की 6. 16.

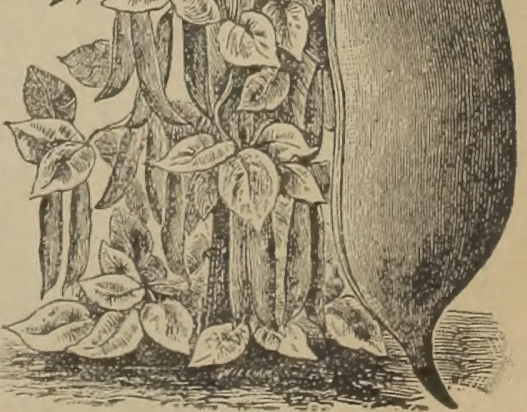



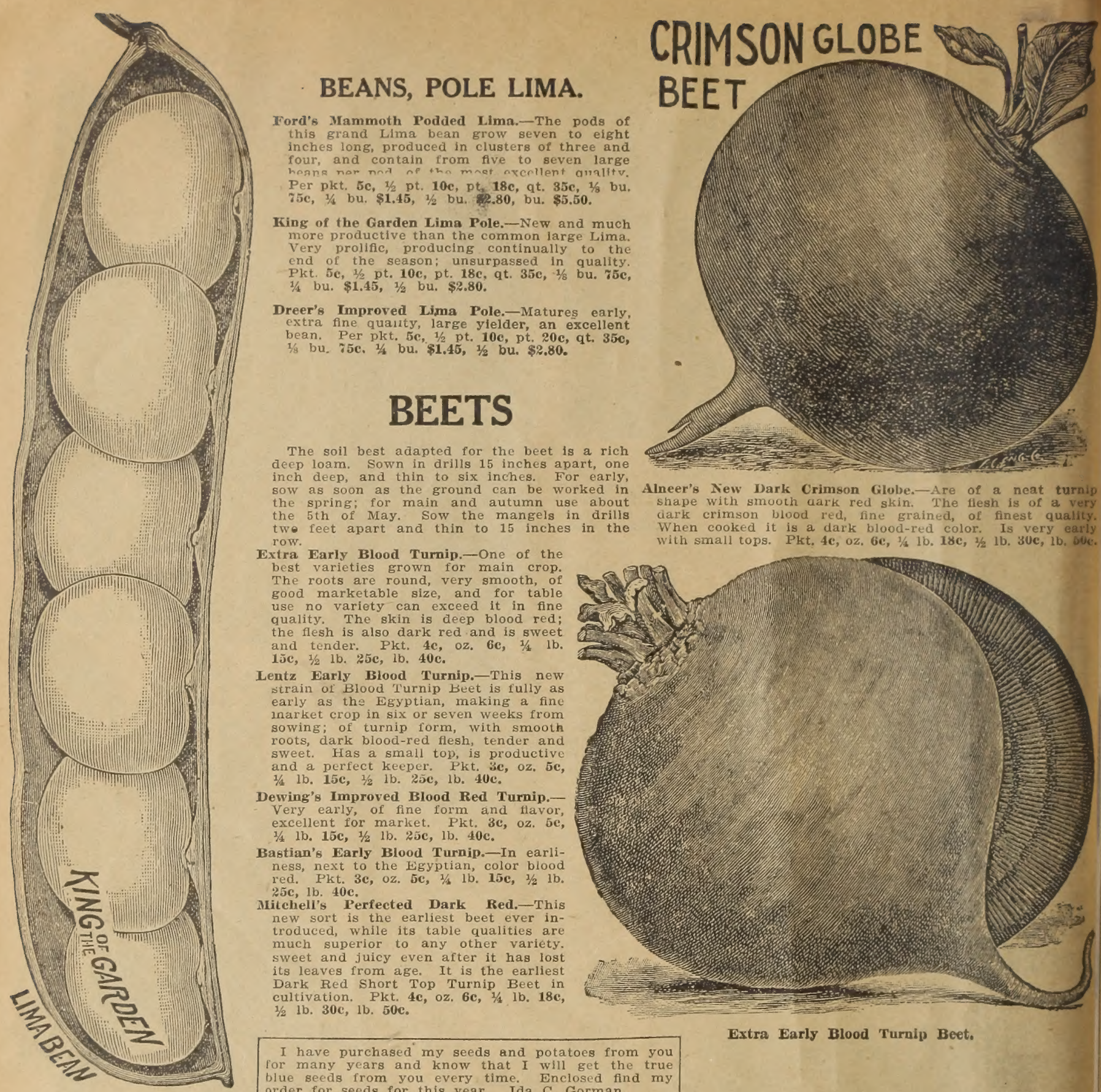

Ford's Mammoth Podded Lima.-The pods of this grand Lime bean grow seven to eight inches long, produced in clusters of three and four, and contaln from five to seven large Per pkt. 5c, $3 / 2$ pt. 10c, pt, 18c, qt, 35e, $1 / 3$ bu 75e, $1 / / 6$ bu. $\$ 1.45,1 / 2$ bu. $\$ 2.80$, bu. $\$ 5.50$.

King of the Garden Lima Pole.-New and muc more productive than the common large Lima. end of the producing continually to the Pkt. 5e, 1/, pt. 10c, pt. 18c, qt. $35 \mathrm{c}, 1 / 8$ bu. $75 \mathrm{c}$ $1 / 4$ bu. $\$ 1.45,1 / 2$ bu. $\$ 2.80$.

Dreer's Improved Lima Pole.-Matures early, bean. Per pkt. 5c, 1/\% pt. 10e, pt, an excellent , $20 \mathrm{c}, \mathrm{qt} .35 \mathrm{c}$ bean. Per pkt. 5c, $1 / 2$ pt. 10e, pt, 20c,
$1 / 8$ bu. 75 c. $1 / /$ bu. $\$ 1.45,1 / 2$ bu. $\$ 2.80$.

\section{BEETS}

The soil best adapted for the beet is a rich deep loam. Sown in drills 15 inches apart, on sow as soon as the ground can be worked in the spring; for main and autumn use about twe feet apart and thin to 15 inches in the

Extra Early Blood Turnip.-One of the best varieties grown for main crop. best varieties grown for main crop.
The roots are round, very smooth, of The roots are round, very smooth, of use no variety can exceed it in fine quality. The skin is deep blood red the llesh is also dark red and is sweet and tender, Pkt, 4c,

Lentz Early Blood Turnip.-This new al Blood Turnip beet is fully as early as the Egyptian, making a fine sowing; of turnip form, with smooth roots, dark blood-red flesh, tender and and a perfect keeper. Pkt $3 e^{2}, 0 z$, 50 1/4 $15 \mathrm{c}, 1 / \mathrm{b}, 25 \mathrm{c}, 1 \mathrm{~b}, 40 \mathrm{c}$

Dewing's Improved Blood Red Turnip.Very early, of fine form and flavor, $1 / 1 / 2$ lb. 15c, $1 / 2$ lb. 25e, 1b. $40 \mathrm{c}$

Bastian's Early Blood Turnip.-In earliness, next to the Egyptian, color blood red. Pkt, 3c, oz, 5e, $1 / 3,1 b, 15 c, 1 / 2,1 b$ Litchell's Perfected Dark Red,-This new sort is the earliest beet ever in-
troduced, while its table qualities are troduced, while its table qualities are sweet and juicy even after it has lost its leaves from age. It is the earliest Dark Red Short Top Turnip Beet in $1 / 2$ Ib. $30 \mathrm{c}, 1 \mathrm{~b} .50 \mathrm{c}$.

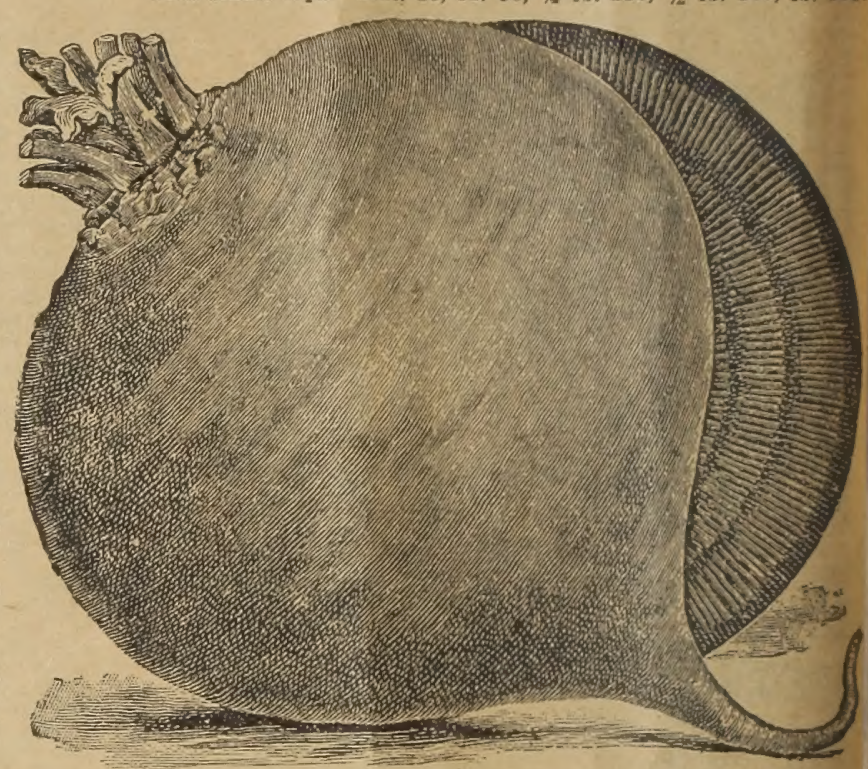

I have purchased my seeds and potatoes from you Extra Early Blood Turnip Beet. blue seeds from you every time. Enclosed find my order for seeds for this year. Ida C. Gorman,

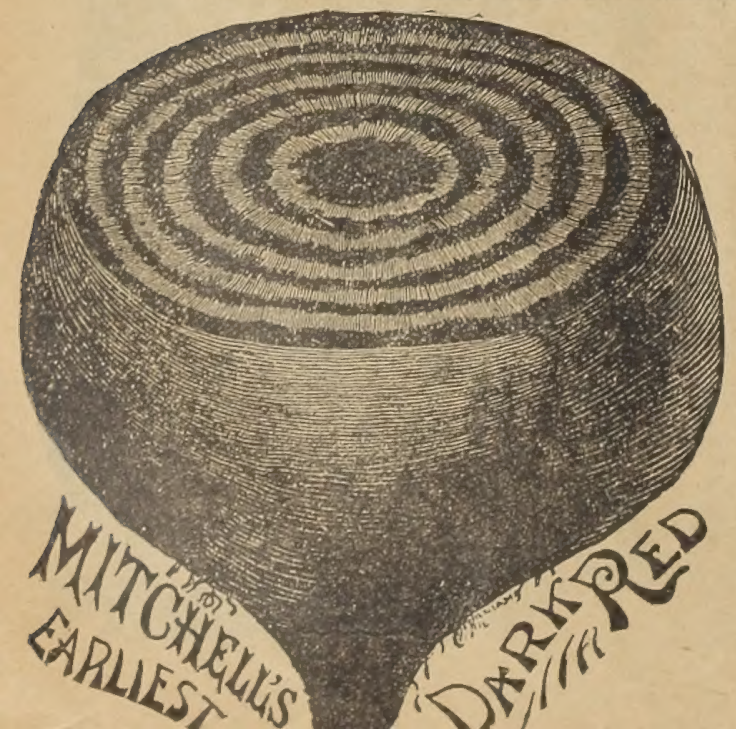

Alneer's Dark Red Meteor.This is indeed a model variety, extremely smooth and of symmetrical growth, fine rich color and desirable shape. It makes a rapid growth and matures very early. The shape is nearly round and color of flesh a rich dark blood red. In quallty it is most excellent. being sweet, tender and free from coarseness. It retain all the good qualities either when grown under glass or outside in the open garden. Pkt. 4c, oz. 7e, 1// lb. 20c, 1/2 1b. $35 \mathrm{c}, 1 \mathrm{~b} .60 \mathrm{c}$.

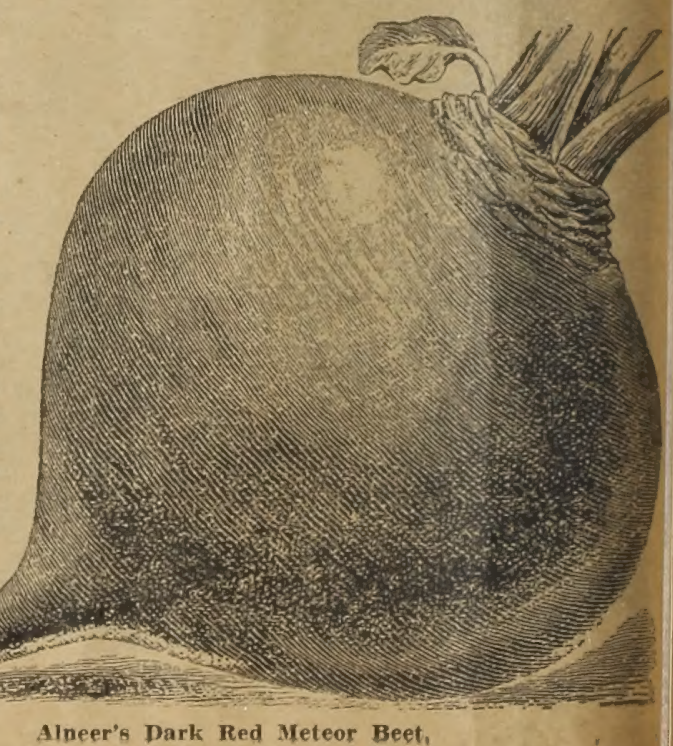



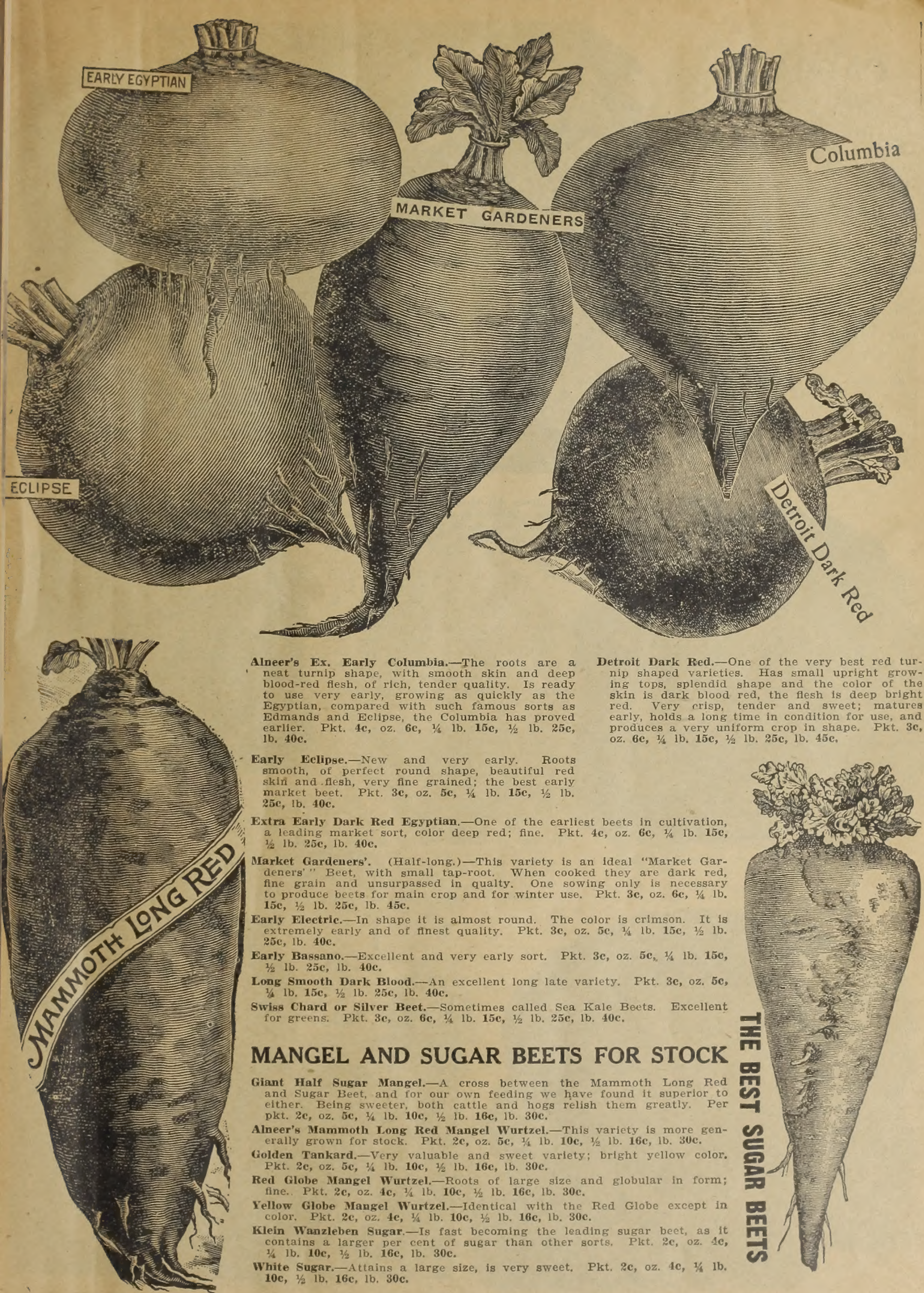

Alneer's Ex. Early Columbia.-The roots are a neat turnip shape, with smooth skin and deep blood-red flesh, of rich, tender quality. Is ready to use very early, growing as quickly as the Egyptian, compared with such famous sorts as Edmands and Eclipse, the Columbio has proved earlier. Pkt. 4c, oz. 6c, 1// lb. 15c, 1/2 lb. 25c, earlier.

Detroit Dark Red.-One of the very best red turing tops, splendid shape and the color of th skin is dark blood red, the flesh is deep bright red Very rrisp, tender and sweet; mature Velds a long time in conditio produces a very uniform crop in shape. Pkt. 3c,

Early Eclipse,-New and very early. Roots smooth, of perfect round very early. Roots skin and.flesh, very fine grained; the best early market beet. Pkt. 3c, oz, 5c, 1/1 1b. 15e, 1/ lb. $25 \mathrm{c}, \mathrm{lb}, 40 \mathrm{c}$

Extra Early Dark Red Egyptian -One of the earliest beets in cultivation, leading market sort, color deep red; fine, Pkt, $4 c, 0 z$. 6c, $1 / 4$ lb. $15 c$ $1 / 2$ lb. $25 \mathrm{c}, 1 \mathrm{~b} .40 \mathrm{c}$.

Market Gardeuers". (Half-long.)-Thjs variety is an ideal "Market Gardeners'" Beet, with small tap-root. When cooked they are dark red, fine grain and unsurpassed in qualty. One sowing only is necessary to produce beets for main crop and for winter use, Pkt, 3c, oz. 6c, 1/4 Ib. $15 \mathrm{c}, 1 / 2 \mathrm{lb}, 25 \mathrm{c}, 1 \mathrm{~b}, 45 \mathrm{c}$

Early Electric. - In shape it is almost round. The color is crimson. It is extremely early and of finest quality. Pkt, 3e, oz. 5e, 1/4 1b, 15e, 1/2 lb. $25 \mathrm{c}, 1 \mathrm{~b}, 40 \mathrm{c}$

Early Bassano,-Excellent and very early sort. Pkt, 3c, 0z. 5c, 1/4 1b. 15c, 1b. $25 \mathrm{c}, 1 \mathrm{~b}, 40 \mathrm{c}$

Long Smooth Dark Blood.--An excellent long late variety. Pkt. 3c, oz. 5c, $1 / 4$ lb. 15e, $1 / 21 \mathrm{~b}$. 25e, Ib. 40e.

Swiss Chard or Silver Beet,-Sometimes called Sea Kale Boets. Excellent for greens. Pkt, $3 \mathbf{e}$, oz. $6 \mathrm{c}, 1 / 4 \mathrm{lb}$.

\section{MANGEL AND SUGAR BEETS FOR STOCK}

Giant Holf Sugar Mangel-A cross between the Mammoth Long Red and Sugar Beet, and for our own feeding we have found it superior to either. Being sweeter, both cattle and hogs relish them greatly. Per pkt, 2c, oz, 5e, $1 / 4$ lb, 10e, 1/2 lb, 16c, lb, 30c

Alneer's Mammoth Long Red Mangel Wurtzel.-This variety is more generally grown for stock. Pkt. $2 \mathrm{c}, \mathrm{oz}$. 5e, $1 / 1 \mathrm{lb} .10 \mathrm{c}, 1 / 21 \mathrm{~b} .16 \mathrm{c}, 1 \mathrm{~b} .30 \mathrm{c}$. Golden Tankard,-Very valuable and sweet varlety; bright yellow color. Pkt. 2e, oz. 5e, 1/4 lb, 10e, 1/2 Ib, 16e, Ib, 30c.

Red Globe Mangel Wurtzel.-Roots of large size and globular in form; fine. Pkt. 2c, oz. 4c, $1 / 4$ lb. 10e, $1 / 2 \mathrm{lb}, 16 \mathrm{c}, \mathrm{Ib}, 30 \mathrm{c}$

Yellow Globe Mangel Wurtzel.-Identical with the Red Globe except in color, Pkt. 2c, oz, 4c, $1 / 4$ lb, 10e, 1/2 lb, 16e, 1b, 30c.

Klein Wanzleben Sugar.-Is fast becoming the leading sugar beet, as it contains a larger per cent of sugar than other sorts, Plst. Re, oz. Ac, dis $1 \mathrm{~b}, 10 \mathrm{c}, 1 / 2 \mathrm{lb}, 16 \mathrm{c}, 1 \mathrm{~b}, 30 \mathrm{c}$

White Sugar.-Attains a large size, is very sweet. Pkt. 2c, oz. 4c, 1// lb.

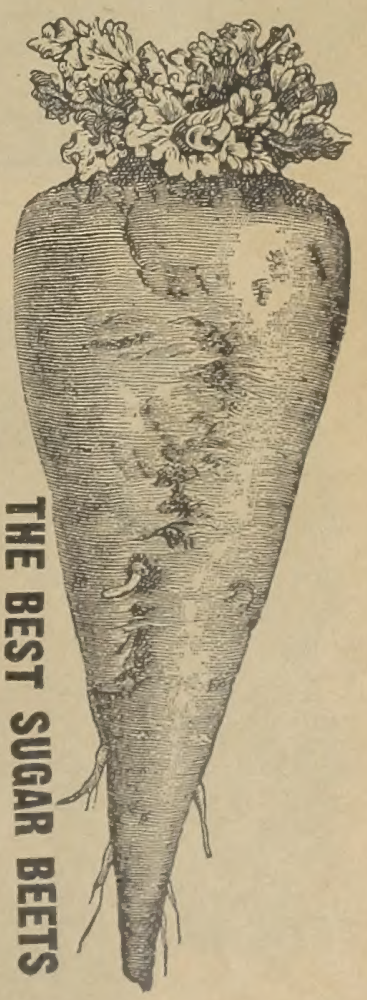




\section{CABBAGE}

American Grown Seeds.

For early use, sow seeds in hot beds rows and $21 / 2$ feet between the plants. Extra Selected Early Jersey Wakefteld. originators of the well known Jersey been hig.h Cabbase. This strain ha There is none better. Pkt. 5c, oz, 20c, seed such as is generaily sold. Pkt. 4c, oz.
$\$ 1.20$.

All Season'8. This excellent cabbage a its name indicates, is good for al early and late variety. It is remarkably sure for heading and makes a Pkt. 3e, oz. 12e, $1 / 4$ lb. 40e, $1 / 2$ lb. roc, lb. $\$ 1.30$. as possible in the ground about 18 $1 / 4$ lb, 60c, $1 / 2$ lb. $\$ 1.10,1 \mathrm{~b}, \$ 2.00$ Jersey Wakefield. Very
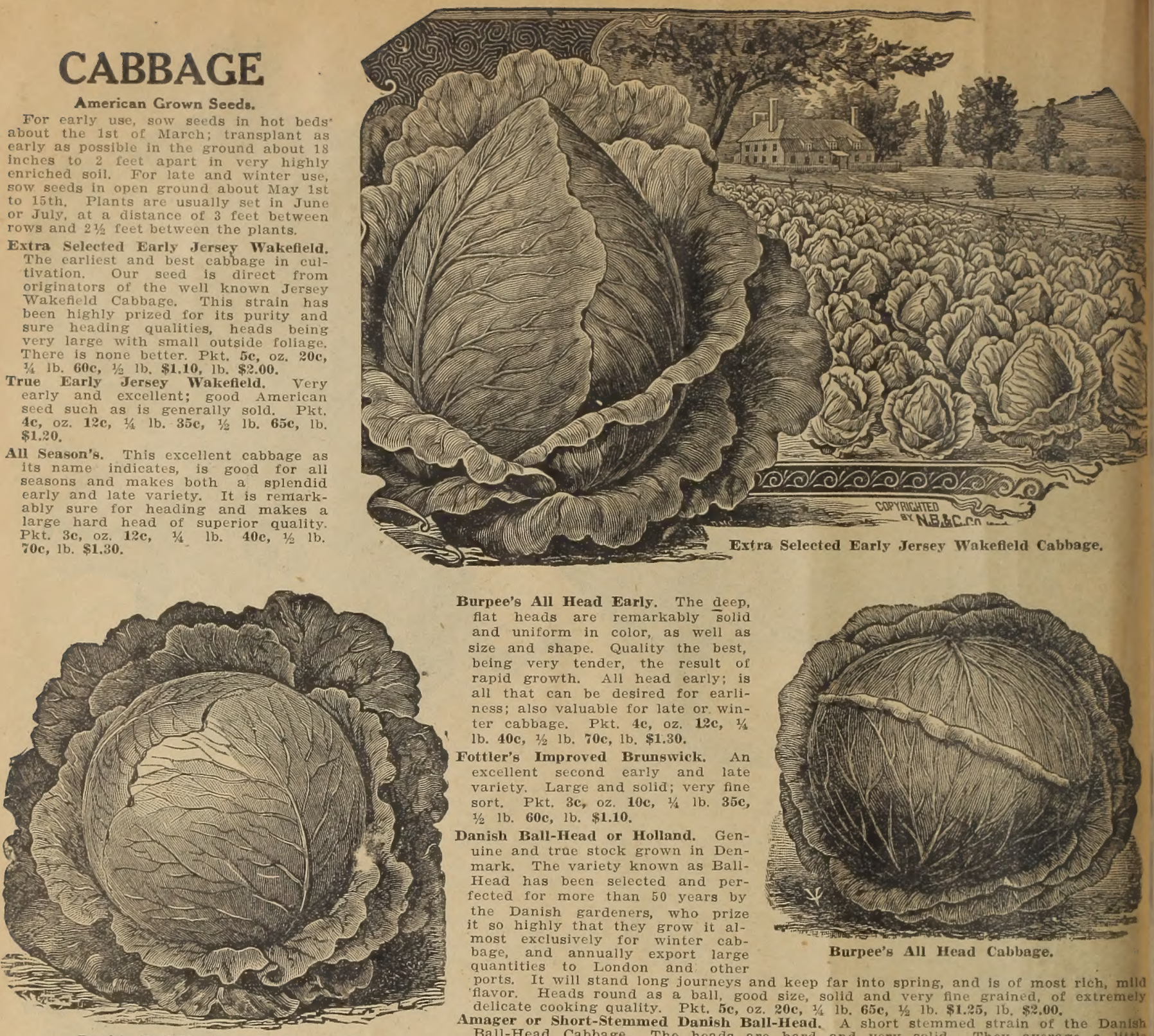

Burpee's All Head Early. The deep flat heads are remarkably solid and uniform in color, as well as she and shape. Quality the best, rapid vrowth ness; also valuable for late or win1b. $40 \mathrm{c}, 1 / 2$ lb. 70c, 1b. $\$ 1,30$.

Fottler's Improved Brunswick. An excellent second early and late sort. Pkt. 3c, oz. 10c, $1 / 4$ lb. 35e, $1 / 2$ 1b. $60 \mathrm{c}, 1 \mathrm{~b} . \$ 1.10$.

Danish Ball-Head or Holland. Gen-
uine and true stock grown in Den-
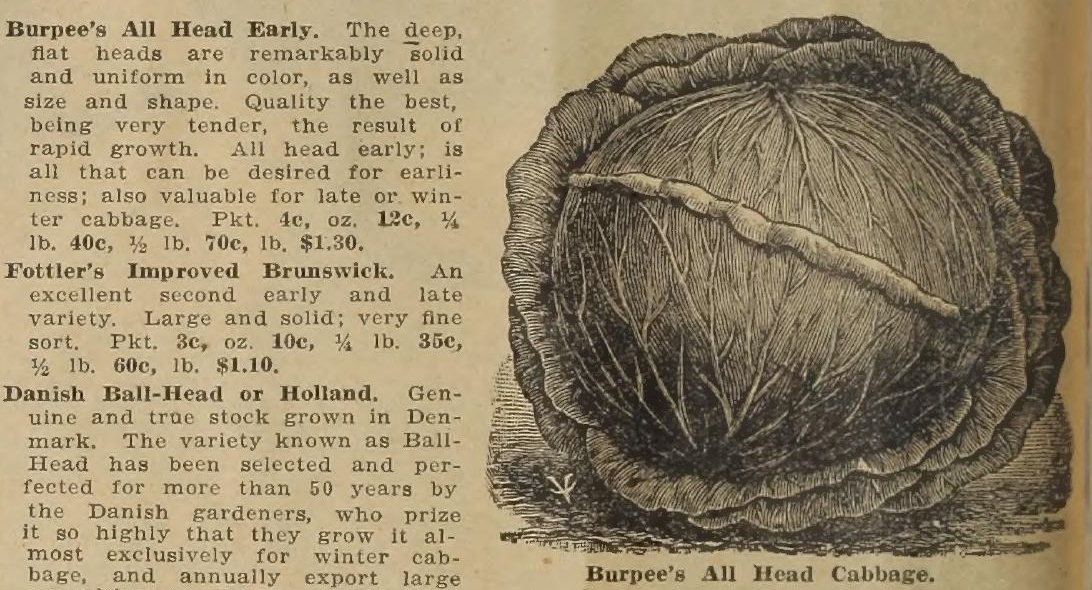

Burpee's All Head Cabbage.

ports. It will stand long fourneys and keep far into spring and is of most rich, mlle flavor. Heads round as a ball good size, solid and very f a ds of most ilch, mely delicate cooking quality. Pkt. 5c, oz. 20c, $1 / 4 \mathrm{~b}$. 65e, $1 / 21 \mathrm{~b} . \$ 1.25,1 \mathrm{~b}, \$ 2,00$.

mager or Short-Stemmed Danish Ball-Head. A short stemmed strain of the Danish Ball-Head Cabbage. The heads are hard and very solid. They average a little flavor, crisp and tender. It is less liable to blight and shows vigorous growth even in the hot summer. Preferred by some to the long stemmed. They are splendid
keepers. Pkt. 5c, oz. 20c, 1/4 lb. 65̃c, $1 / 21$ lb. $\$ 1.25,1 b . \$ 2.00$.

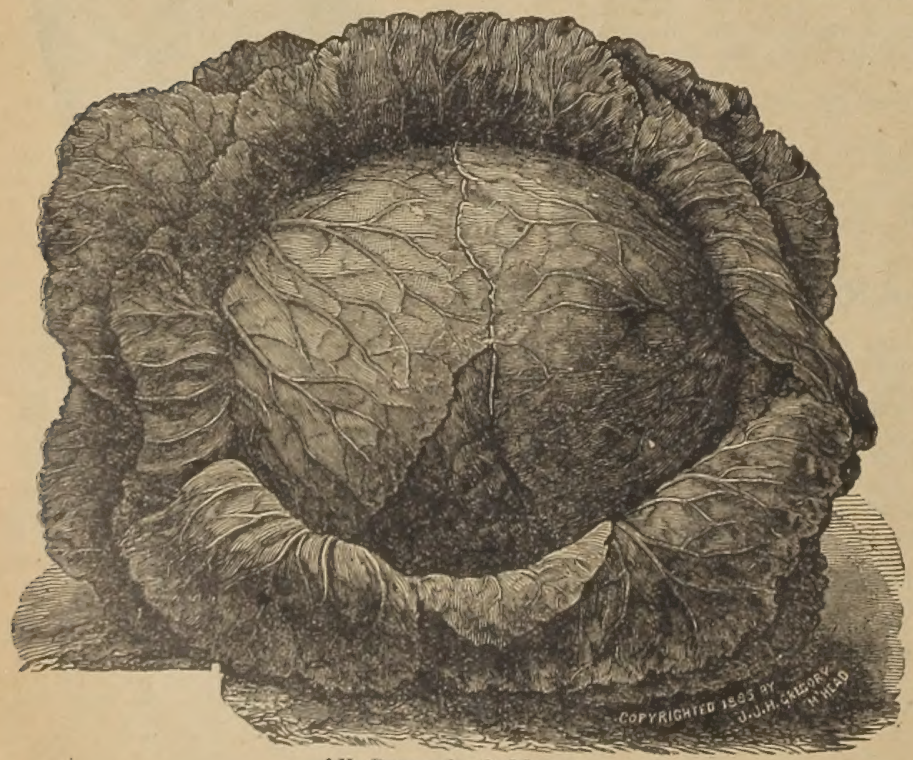

All Season's Cabbage,

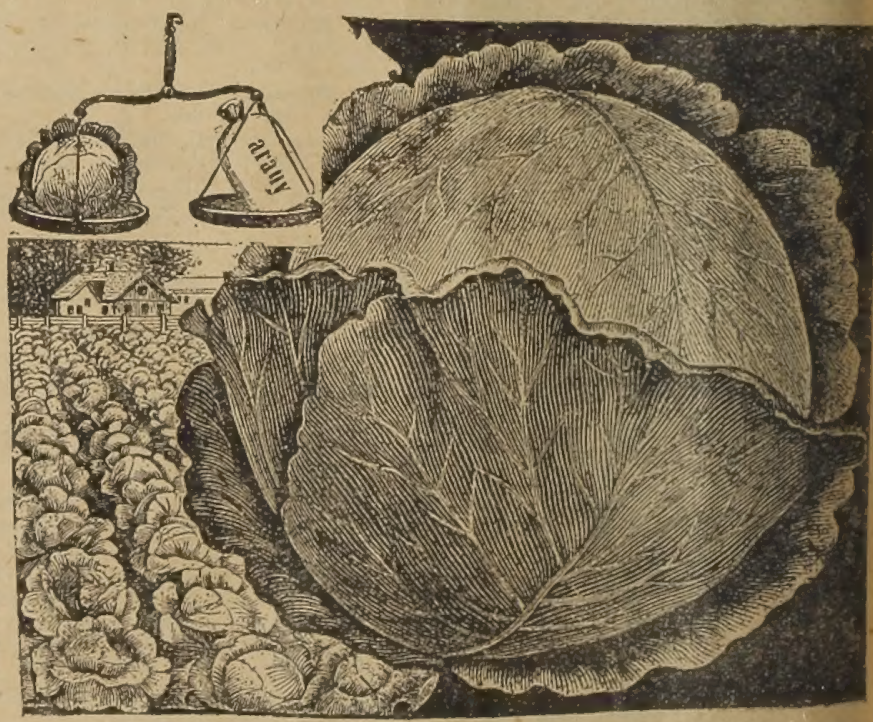

Amager or Short-Stemmed Danish Ball-Head. 

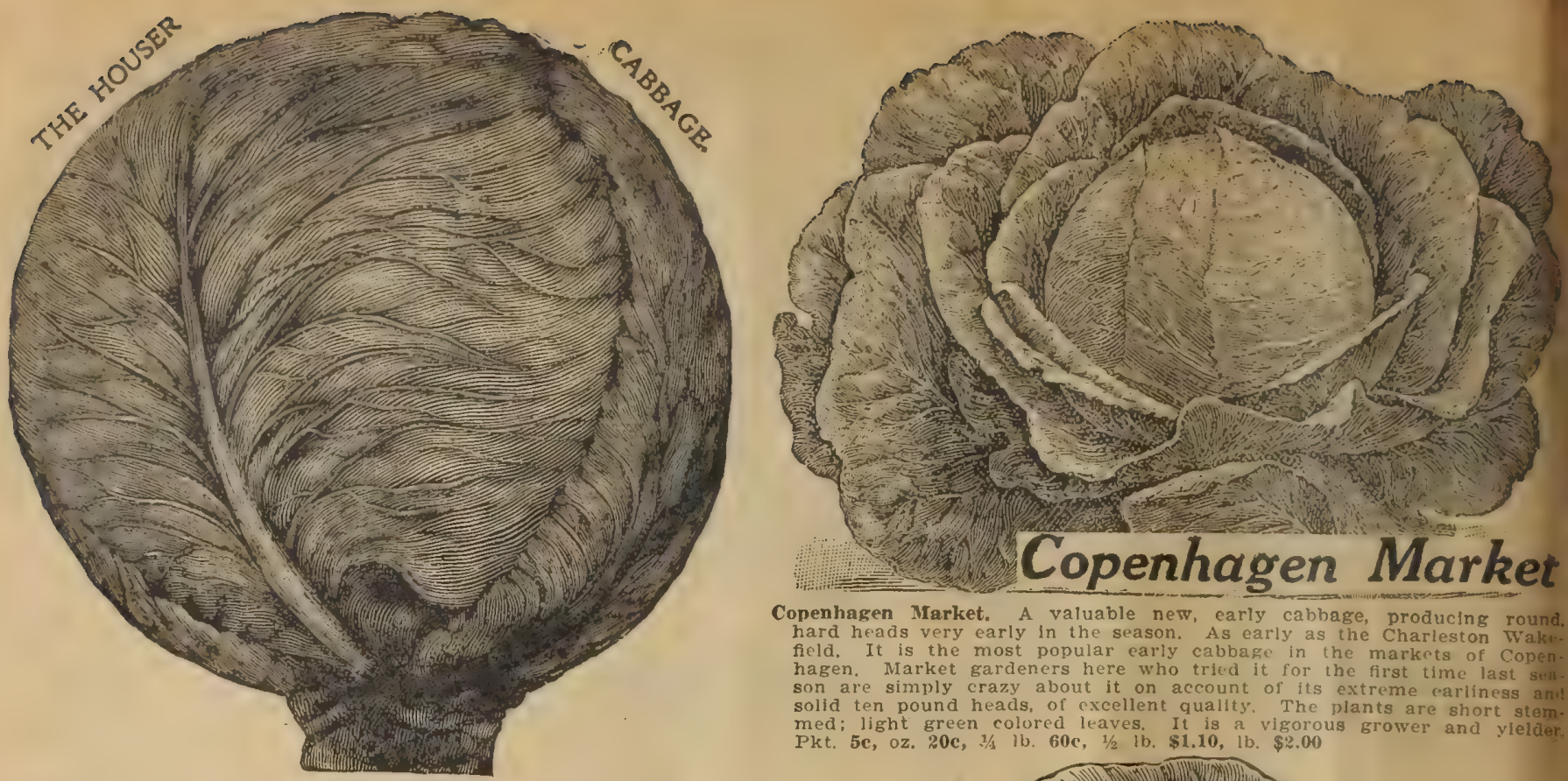

Copenhagen Market. A valuable new, eariy cabbso, producin round hard heads very early in the season. As early as the Charleston Wake hagen. son are simply crazy about it on account of its extreme earliness an med; light green colored leaves. It is a vigorous grower and vielder Houser. The striking engraving made from a photograph gives

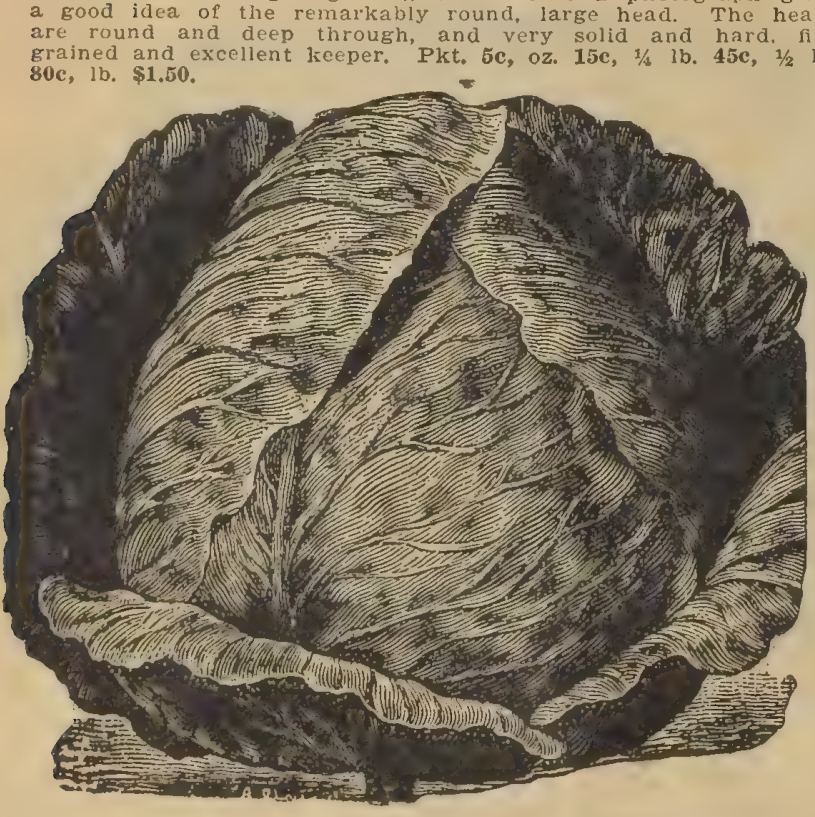

Alneer's Earliest of All Cabbage.

Alneer's Earliest of All. A grand new early cabbage being a week earlicr

than the Wakefela, but smaller, a most destrable sort for the eariest

Pkt. 5e, oz. 15e, 1//2 lb. 55e, $1 / 2$ lb. $\$ 1.00,1 \mathrm{~b}, \$ 1.75$.

and largely grown for winter use. Pkt, 3e, oz, 10c, 1/1 $36.35 c, 1 / 21 b .60 c$ 1b. \$1.10.

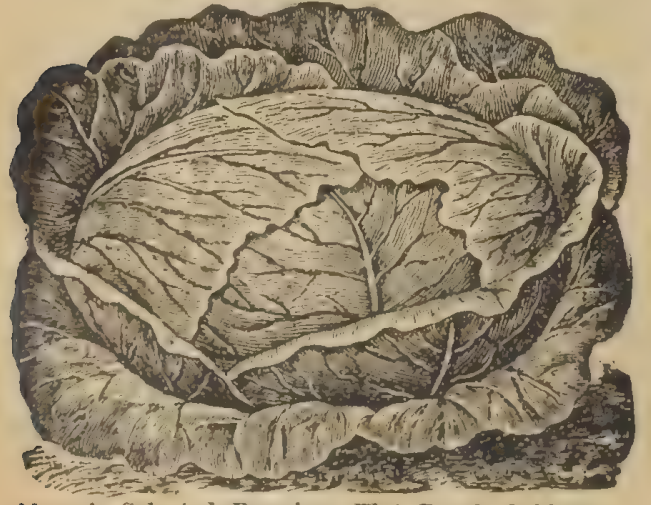

Alneer's Safe Crop. Is

Alneer's Selected Premium Flat Dutch Cabbage. a large late strain of

cabbage. It is a sure

header. The heads are

firm, with but few

short, foliage compact
and of a beautiful

green color. Pkt. 5c,

1b. $75 \mathrm{c}, 1 \mathrm{~b}, \$ 1.40$.

American Drumhead

Savoy. The largest

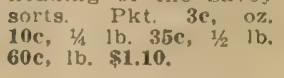

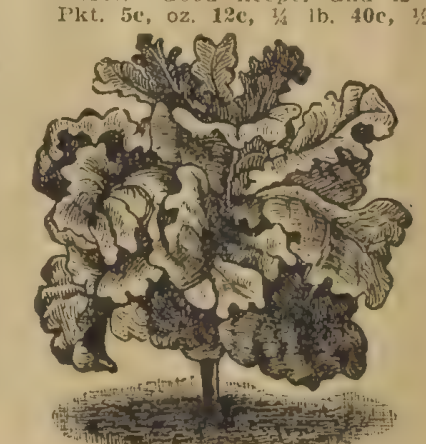

TRUE GEORGIA COLLARDS.

\section{COLLARDS}

Georgin or Creole.-This

in the South. Forms a larke

leaves on a tall stem.

\section{CHICORY}

The leaves are used as stiad

thelr natural state or blanch mix with or be substituted coffee. Large Rooted Magde. 18c. 


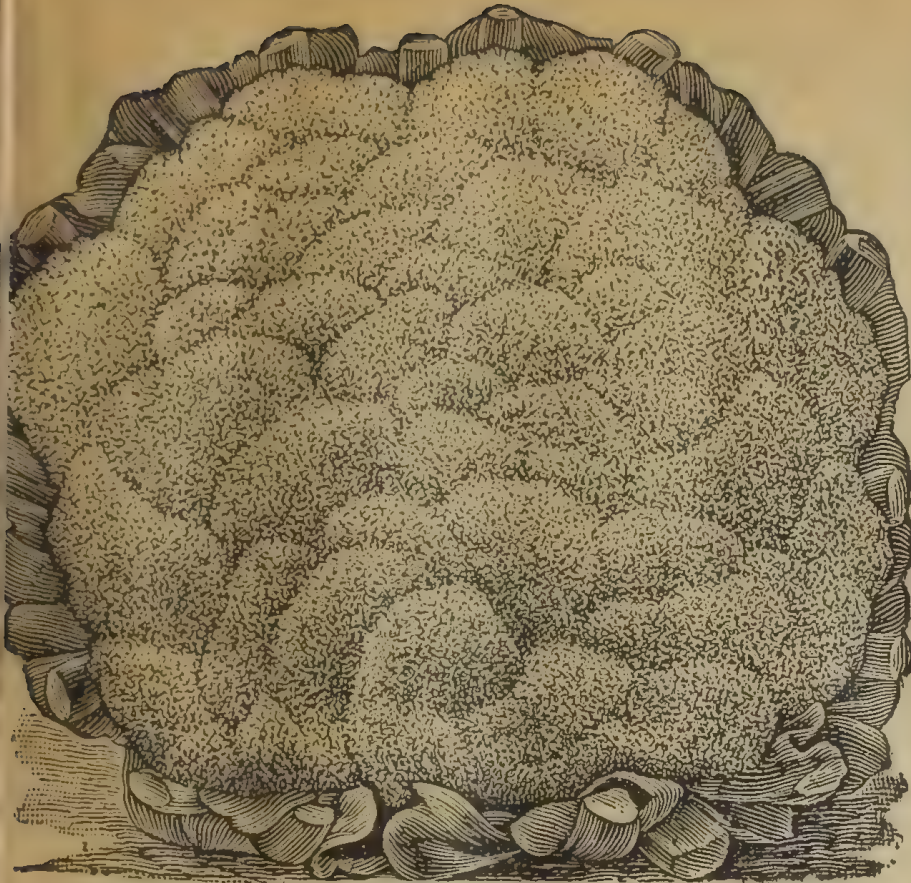

Alneer's Earlient Sure-Head Snowball Cauliflower.

\section{CAULIFLOWER}

neer's Earliest Sure-head Snowball. A grand new fine early Cauliflower grown and perfected by the most careful growers of cauliflower in DenFine gralned and of very best quality. It is the peer of all cauliflowers. Pkt. 15e, 1/2 oz. \$1.30, oz, \$2.50.

enderson's Early Snowball. (True,) A very early dwarf variety, producing fine white hearls of best quality, every plant forming a perfect head can be planted as close as 18 inches apart. Our seeds are genuine headquarters stock. Pkt. 10r, 1,18 oz. \$1.15, oz. \$2:00.

ifra Seleeted Larly Dwarf Erfurt. First quallty seed grown in Europe, One of the very best in cultivation; sure to head. Pkt. 10c, $1 / 2$ oz. $\$ 1.15$, oz. $\$ 2.00$

ib. $\$ 1.00$

Normand's Sloort Stemmed.
Pkt, 5e, oz, 30e, $1 / 1$ lb. $\$ 1.00$

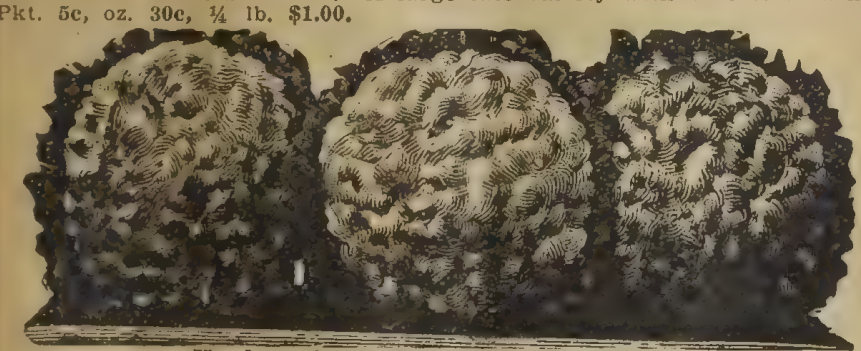

Henderson's Early Snowball Caulifower.

$$
\text { DANISH DRY WEATHER. }
$$

In Danish Dry Weather Caulifower we have a strain that is particularly dapted for growing away from water, and will succeed where others fail. t makes fine, large, solid heads. The Danish Dry weather Cauliflower can ven be grown in such dry-weather states as Arizona. Pkt, 15e, 1/2 oz. \$1.30,

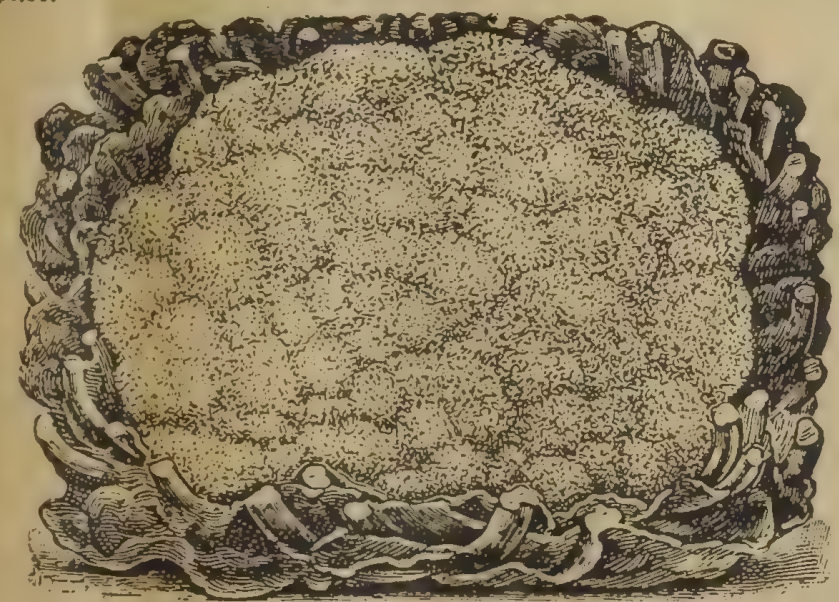

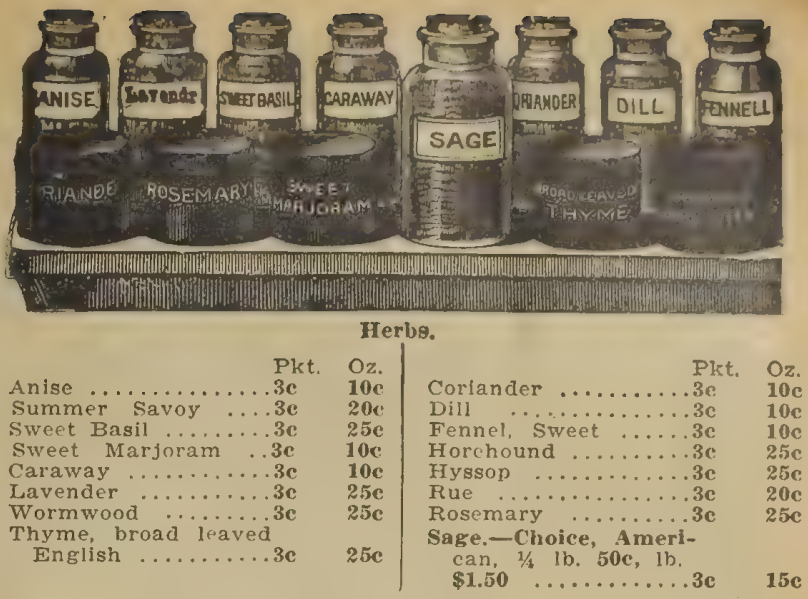

\section{ENDIVE}

Green Curled.

French Moss Curled,-Most beautifully curled, Pkt, 3c, oz. 6c,

Broad Leaved Batavian.-The broad, thick, slightly wrinkled leaves form a large head which
soups. Pkt. 3c, oz, 6e, $2 / 4.1 \mathrm{~b}, 18 \mathrm{c}$.

\section{BRUSSELS SPROUTS}

Brussels Sprouts. Resembles cabbage, excellent fine flavor. Sow seeds in April. The small heads or spro
by frost. Pkt. 3c, oz. 7c, 1/4 lb. 20c.

\section{CRESS or PEPPERGRASS}

Used for salads: of pungent taste.
Extra Curled. Very fine. Pkt, 2c, oz. 5c, $1 / 4$ b. 12c, 1/2 1b. 20e,

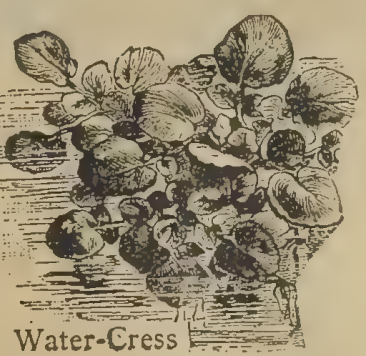

\section{WATER CRESS}

Water Cress. The pleasant and

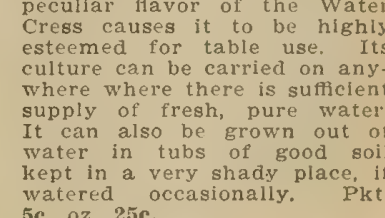

\section{DANDELION}

Dandelion

Thick I.eaved.
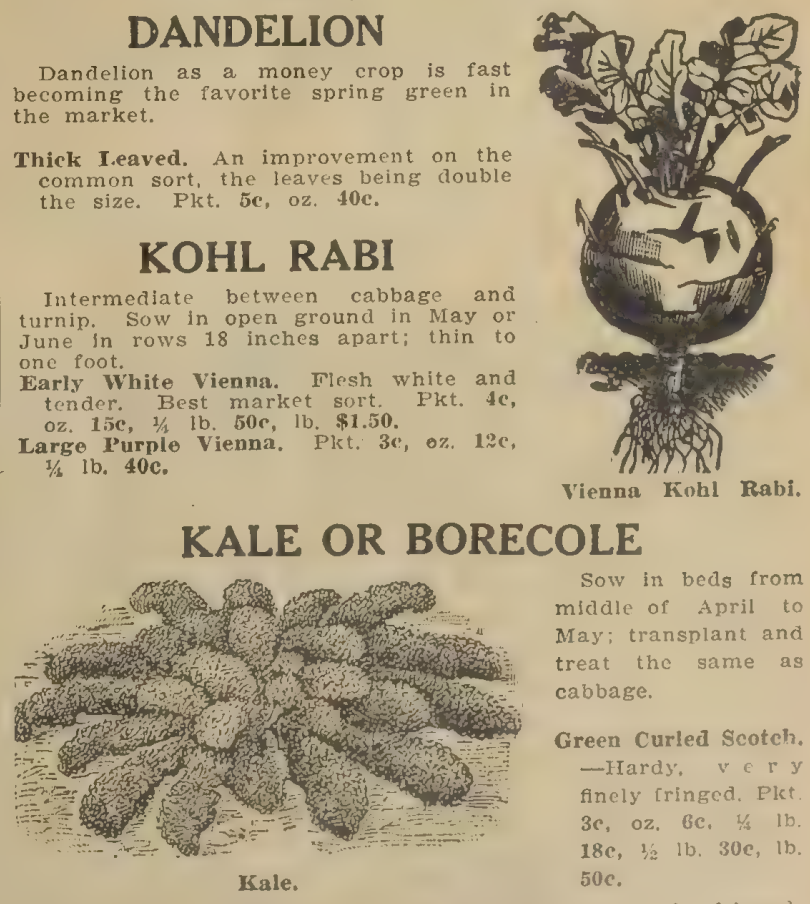

Vienna Kohl Rabi. 


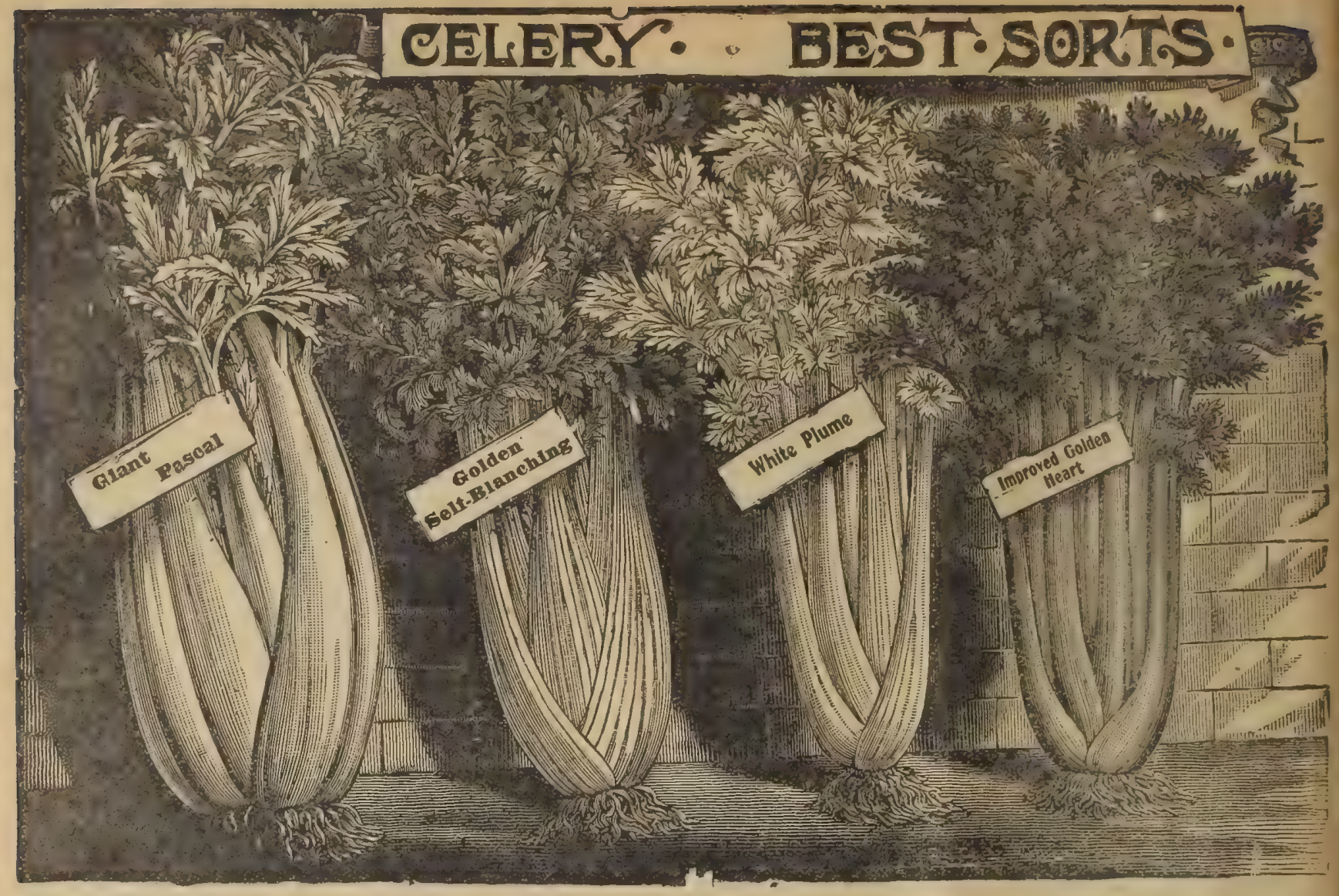

\section{CELERY}

(iolden Self-Blanching (True Paris Gulden). Grows to a very large size and is

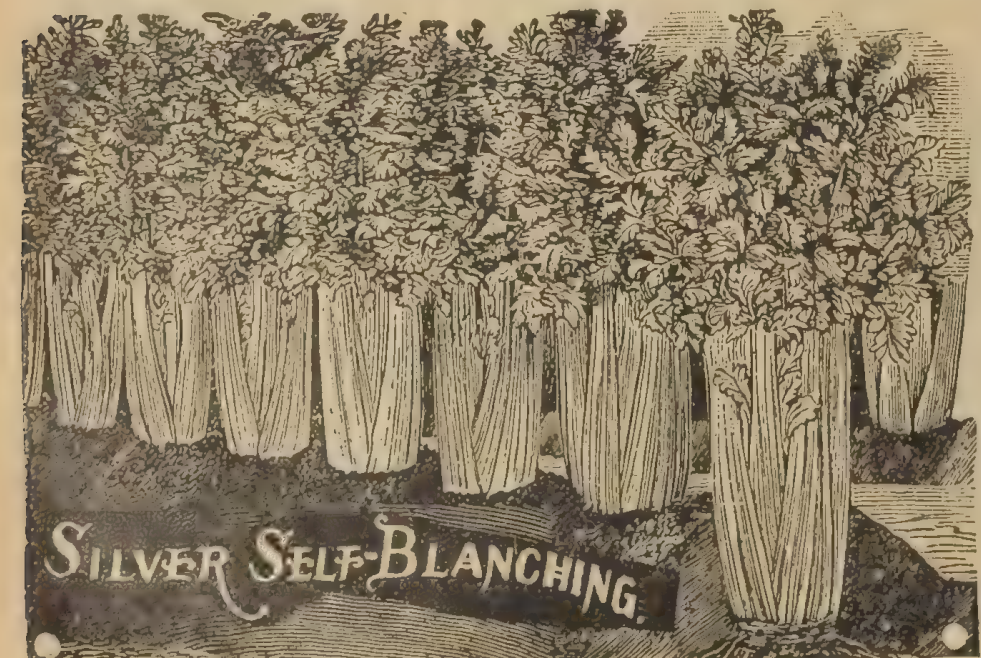

Henderson's Pink Plume. A perfect white plume in charact

Pkt. 4c; oz. 12c; $1 / 1 / 1 \mathrm{~b}, 40 \mathrm{c}$.

Improved Golden Meart. One of the best; heart of beautifu full, is of a waxy golden yellow. Fine flavor, excelle

Christmas Queen.

perfectly solid, crisp

nutty flavor, and wil
keep longer than any
other variety. Pkt.

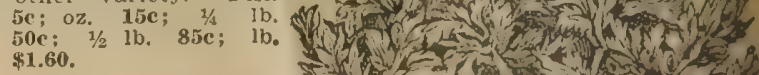
Perfection Heartwell, Evell

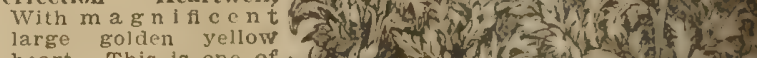
heart. This is one of $3(x)$ tr.t.

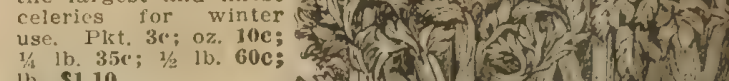

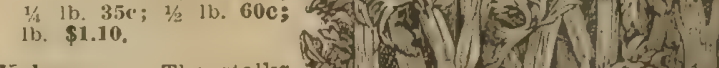

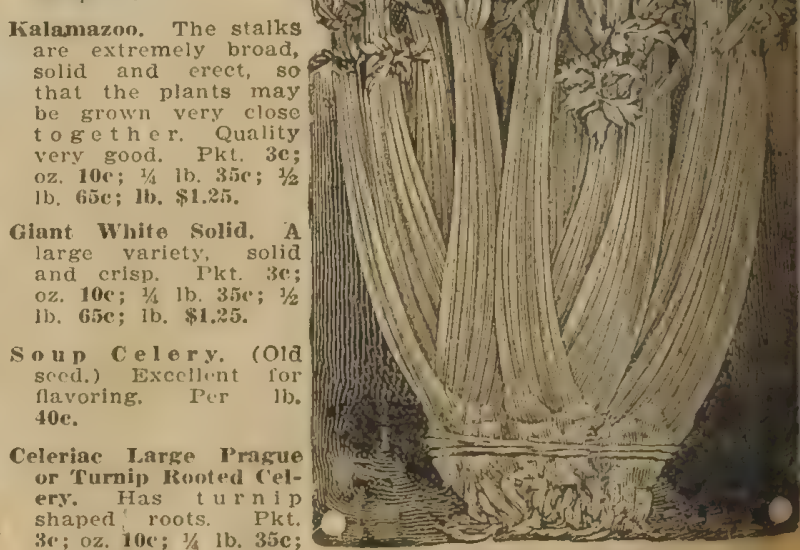
$1 / 2$ ib. $60 \mathrm{c}$ Christmas queen. 


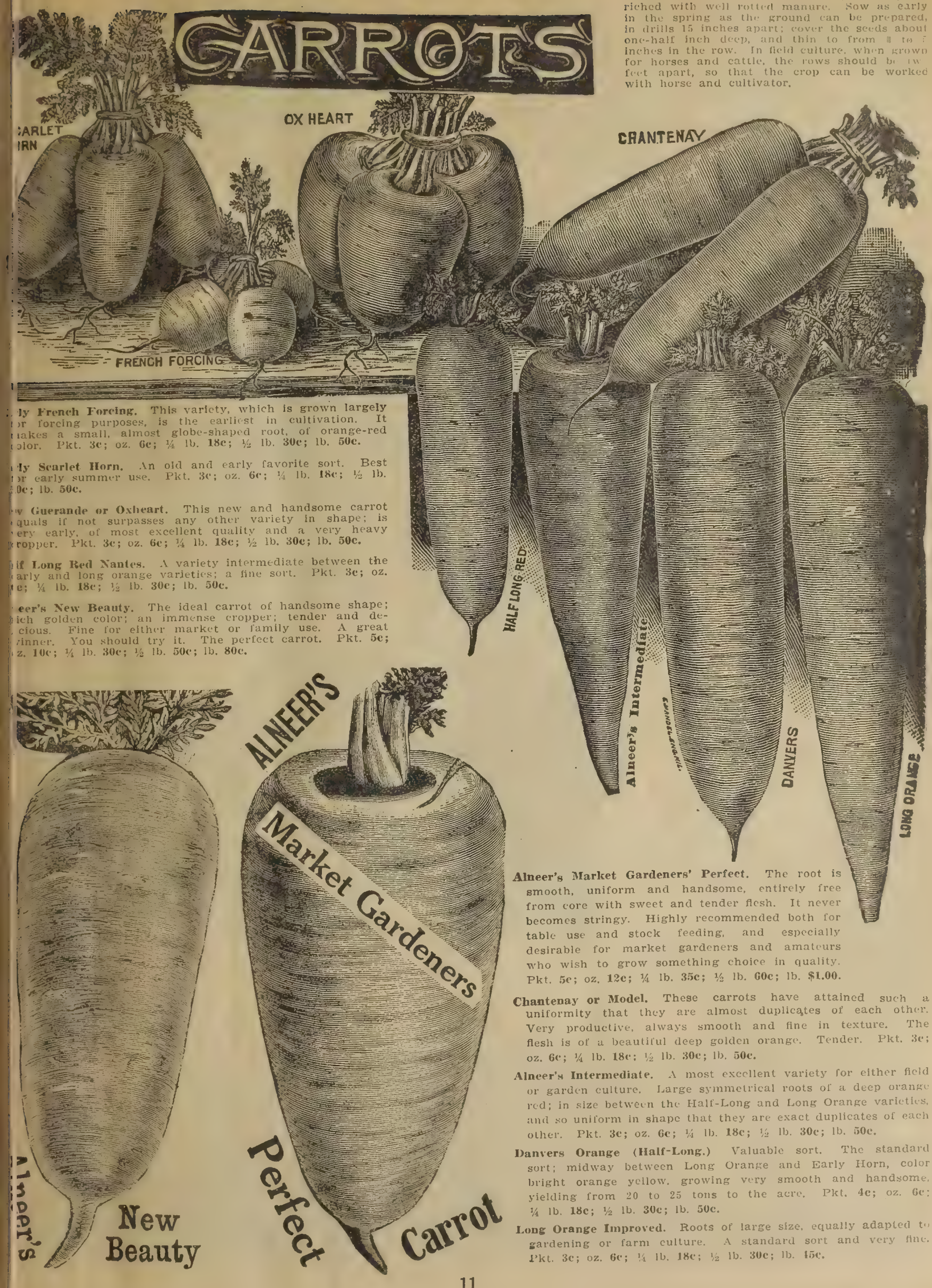




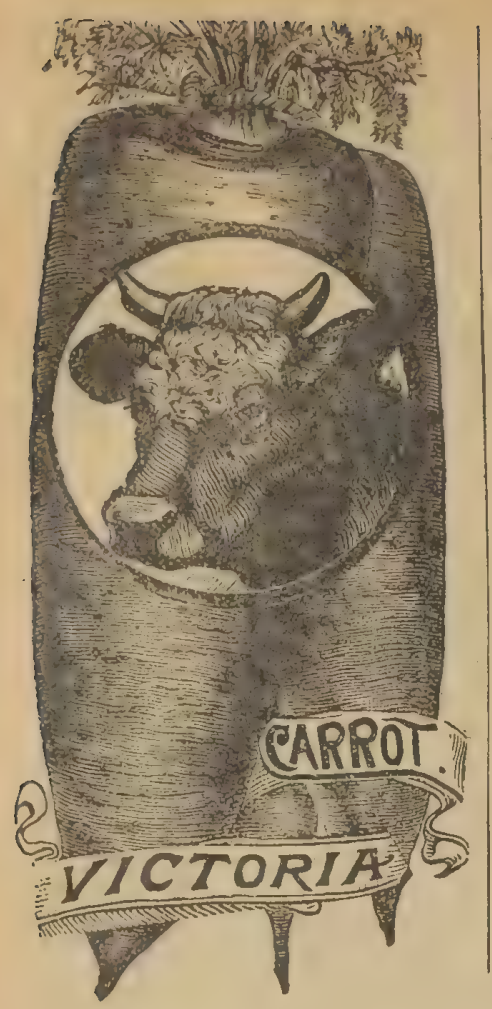

CUCUMBER

best in

arm, rich ground. They round until settled warm each way, when all danleaving three or four of
strongest plants to the Fordhook pickling.

Fordhook l'ickling. it wifontinue to bear pickles plentifully alter the others have ripened their fruit and ce
to produce. It is straight, crisp and tender. Pkt. 4c; oz. 6e; $1 / 6$ ib. $20 c ; 1 / 21 b .35 c ; 1 b$. 60c.
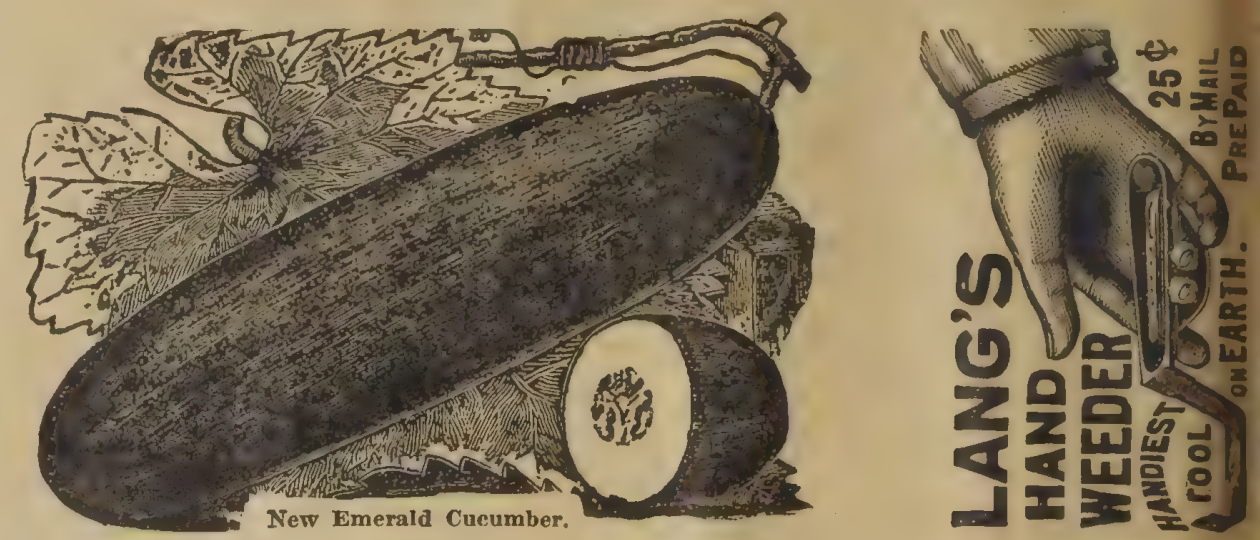

New Emerald. A handsome cucumber of a rich dark gresen color. Is strictly an eversteon. retaining its color until ripe. Has long, straight, handsome fruit, is crisp and tend. T and of the best flavor. Equally good for slicing or pickles.

C.IRROTS-For Stock Feeding.

Mastodon. 'The heaviest cropping carrot grown.

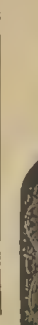

\section{CUCUMBER}

Early Russian. The earliest variety. It sets in 3b. ธ̄0c

Giant Pera. This magnificent variety was brought

Alneer's Exira Long Green Giant. This fine in longth and is of superior quality. Vines are

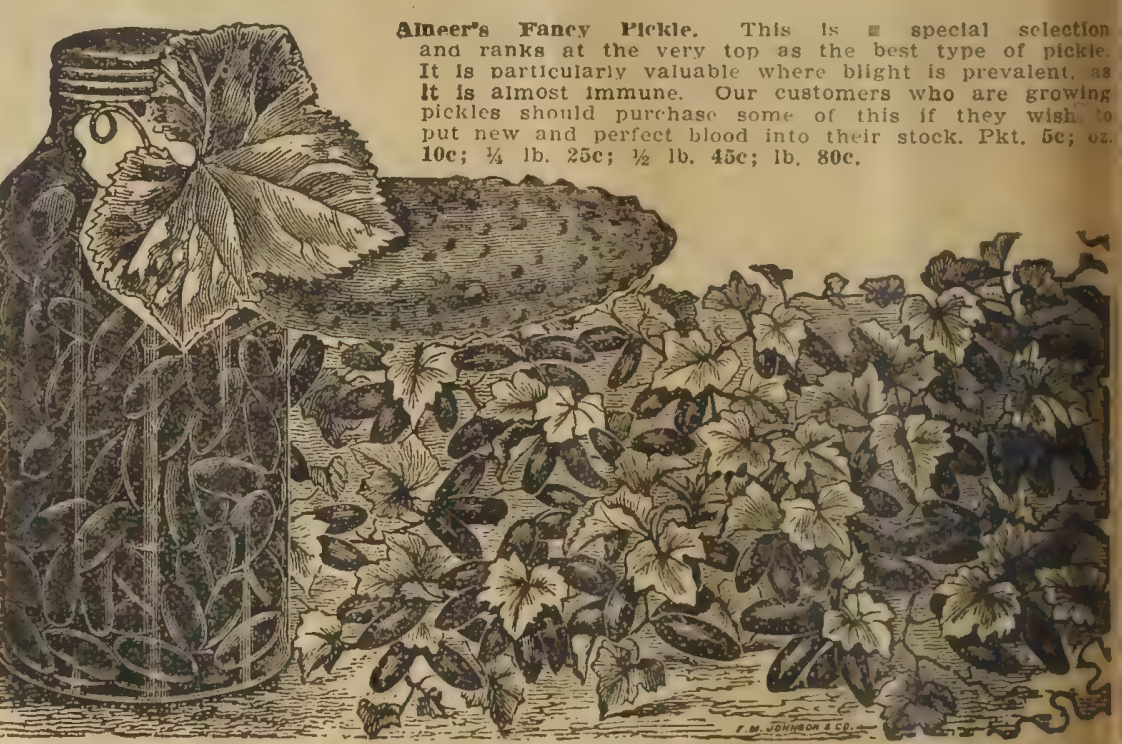

Alneer's Fancy pickle Cucumber.

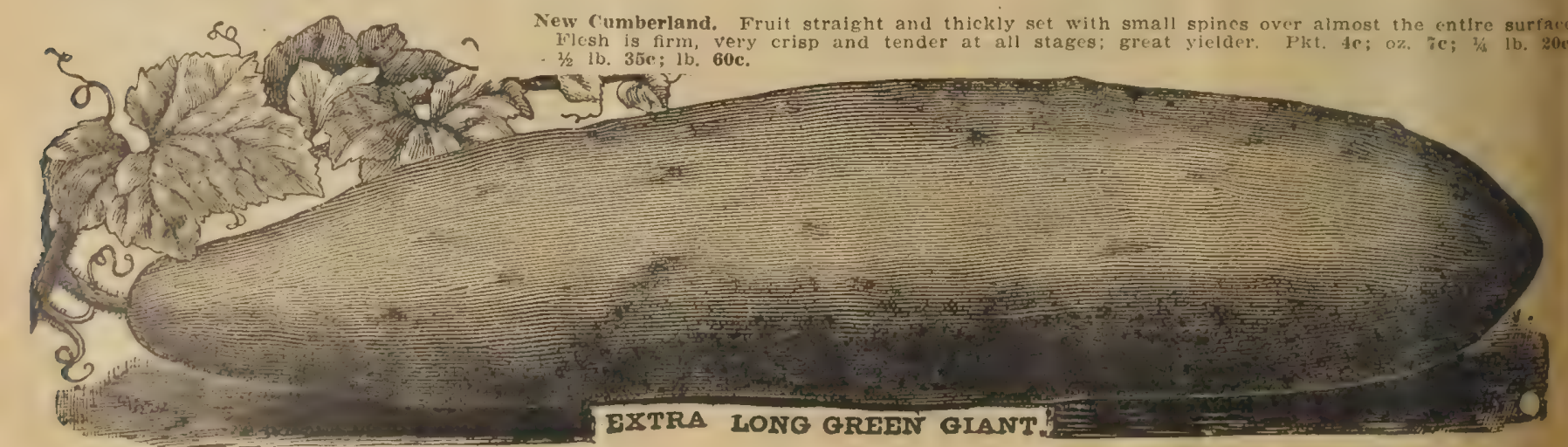



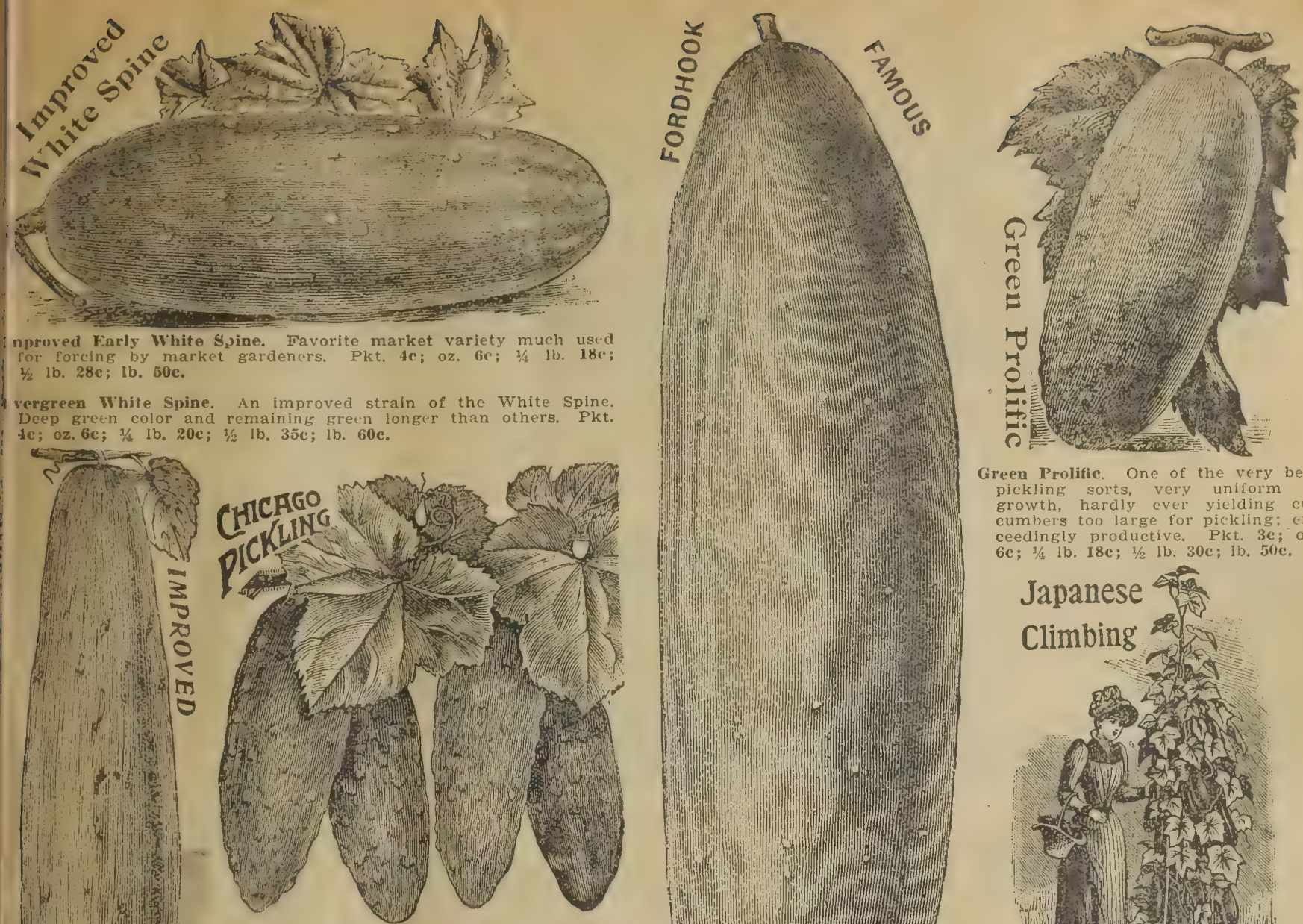

Westerfield's Chicagn Pickle. I very fine, good pickle variety used largely in chicago pickling houses.
$28 \mathrm{e} ; 1 \mathrm{~b}$. $50 \mathrm{e}$.

Improved Iong Gireen. Excellent quality: rruit long, dark, green; fine and crisp. Pk

Fordhook Famous. This new extra long White Spine cucumber produces periectly smooth, very dark green, handsome straight fruit, measuring 12 to 17 inches long. They are always solid, flesh being a greenish white, firm, crisp and of most delicious flavor. It is a great cropper and fruit is full of flesh with but few seeds. Fruit a beatiful green, $1 / 2$ lb. $45 \mathrm{c} ; 1 \mathrm{~b} .80 \mathrm{c}$.
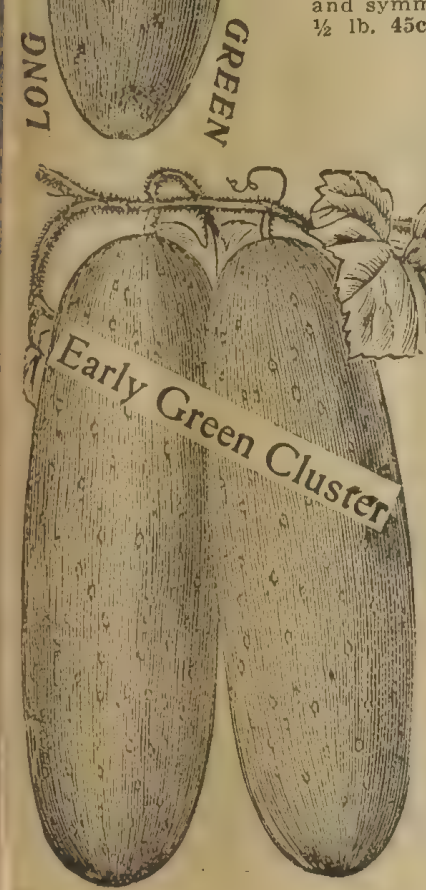

New Paris Pickling. Entirely distinct from all other sorts. It is decidedly the best of all in quality for pickling. So crisp and brittle are they that they snap freely, and when fruit is of unusually rlark green color, Pkt. 4c; oz. 8e; $1 / 4$ Ib $25 \mathrm{c}$; $1 / 2$ lb. $45 \mathrm{c}$; Ib. $80 \mathrm{c}$.

Early Cluster, A short, carly variety, growing in clusters. Pkt. 1e; oz. 6e; 1/ lb. 18c; 1/ 1b. 28e; lb. 50e.

Farly Frame or Short Green. A mopular varicty of medium

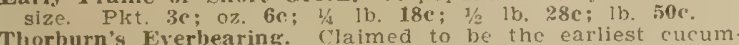
ber in cultivation, and will continue to blossom and bea rruit the entire seasnn, cood for carly us.

Davis Perfect. The shape is ireal. It is almost secdless onethird of its length. An ideal forcing sort of a rich dark

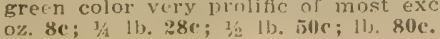

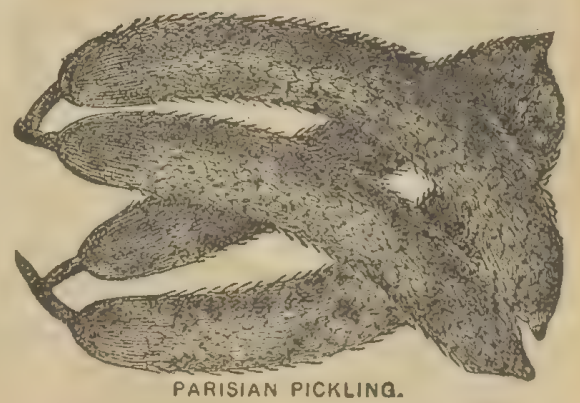

Green Prolific. One of the very best pickling sorts, very unlform in cumbers too large for pickling; exceedingly productive. Pkt. 3c; oz

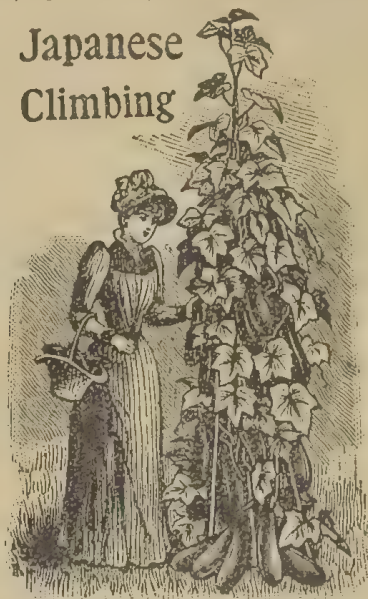

New Japanese Climbing. Entirely distinct, being much more rugged in its constitution and less suscep cucumber, and is immensely more prolific, each vine producing from 25 to 30 cucumbers, even on poo soil. The quality is splendid. Pkt. 5e; oz. 10c; $1 / 1 / 4$ lb. $30 \mathrm{c} ; 1 / 2$ lb. 55e; 5e; $0 \mathrm{z} .10 \mathrm{c} ; 1 / 4$ lb. $30 \mathrm{c}$; $1 / 2$ lb. $55 \mathrm{c}$;
1b. $\$ 1.00$. 


\section{SWEET CORN}

more dwarl varieties should be planted our packets are full size and large as usual.

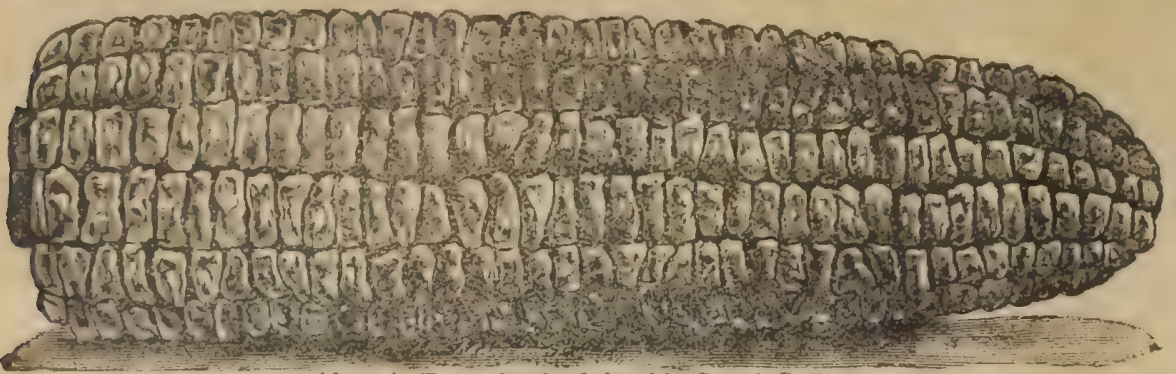

Alneer's Extra Early Columbia Sweet Corn.
Aneer's Extra Early Columbia. The above illustration, made true from Nature, gives some Aneer's Extra Larly Columbia. The above lllustration, made true from Nature, gives some great length, The color is a beautiful crcamy white. In quality, sweetness and flavor it is
superior to any early sort known and is also a heavy yielder. Aineer's Extra Early Columbia
corn is the best and largest corn is the best and largest early sweet corn ever offered
qt. $35 \mathrm{c} ; 1 / 8$ bu. $60 \mathrm{c} ; 1 / 4$ bu. $\$ 1.00 ; 1 / 2$ bu. $\$ 1.80 ;$ bu. $\$ 3.50$.
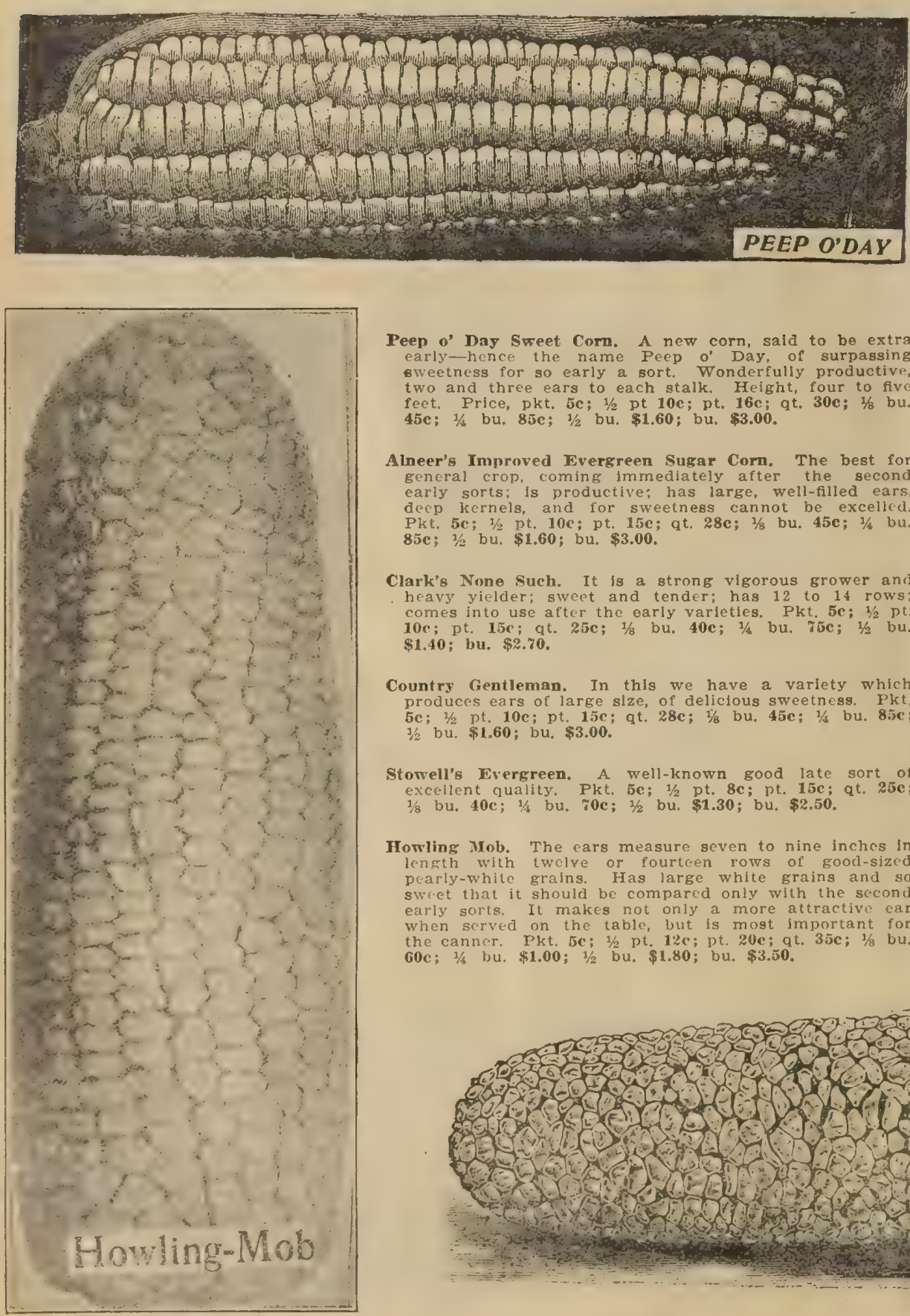

Peep o' Day Sweet Corn. A new corn, sald to be extra early-hence the name Peep $\circ^{\circ}$ Day, of surpassing sweetness for so early a sort. Wonderfully productive, feet. Price, pkt. 5c; $1 / 2$ pt 10e; pt. 16c; qt. 30e; $1 / 8$ bu. $45 \mathrm{e} ; 1 / 4$ bu. $85 \mathrm{c} ; 1 / 2$ bu. $\$ 1.60$; bu. $\$ 3.00$.

Alneer's Improved Evergreen Sugar Corn. The best for general crop, coming immediately after the second deep jornels productive; has large, wet be excelled Pkt. $5 \mathrm{c} ; 1 / 2$ pt. $10 \mathrm{c}$; pt. $15 \mathrm{c}$; qt. 28c; $1 / 8$ bu. $45 \mathrm{c} ; 1 / \mathrm{s}$ bu.

Clark's None Such. It is a strong vigorous grower and

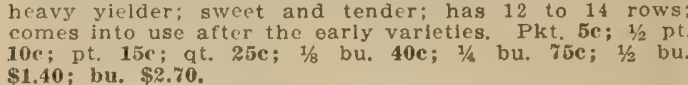
Country Gentleman. In this we have a variety which produces ears of $5 \mathrm{c} ; 1 / 2$ pt. $10 \mathrm{c} ;$ pt. $15 \mathrm{c}$;
$3 / 2$ bu. $\$ 1.60 ;$ bu. $\$ 3.00$.

Stowell's Evergreen. A well-known good late sort of

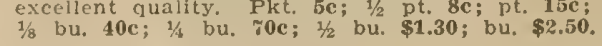

Howling Mob. The ears measure seven to nine inches in pearly-white grains. Has large white grains and so then scrved on the table, but is most important for G0c; $1 / 3$ bu. $\$ 1.00 ; 1 / 2$ bu. $\$ 1.80 ;$ bu. $\$ 3.50$.
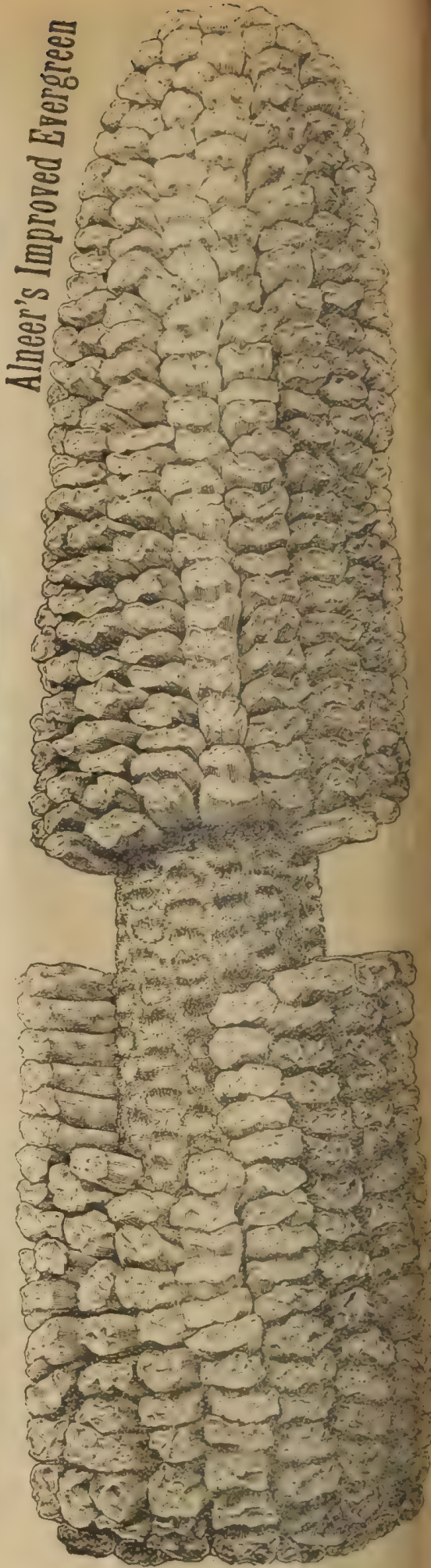

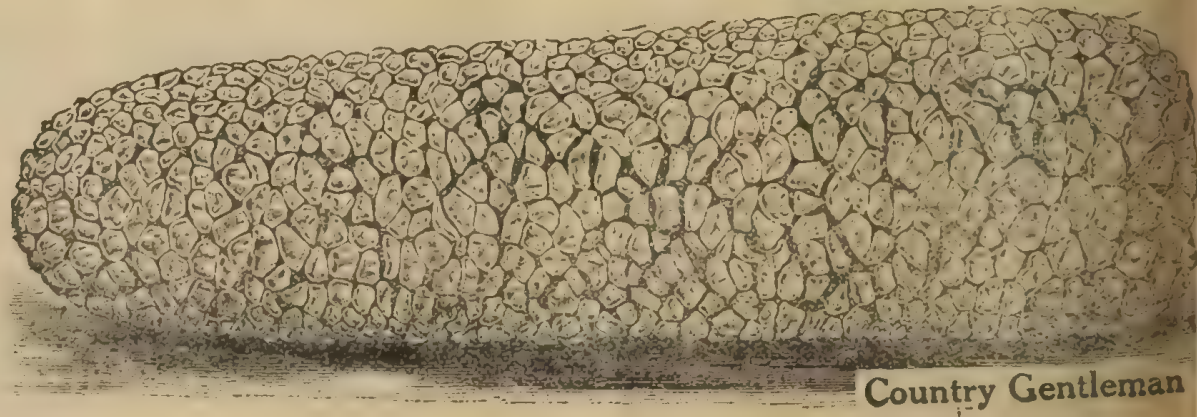




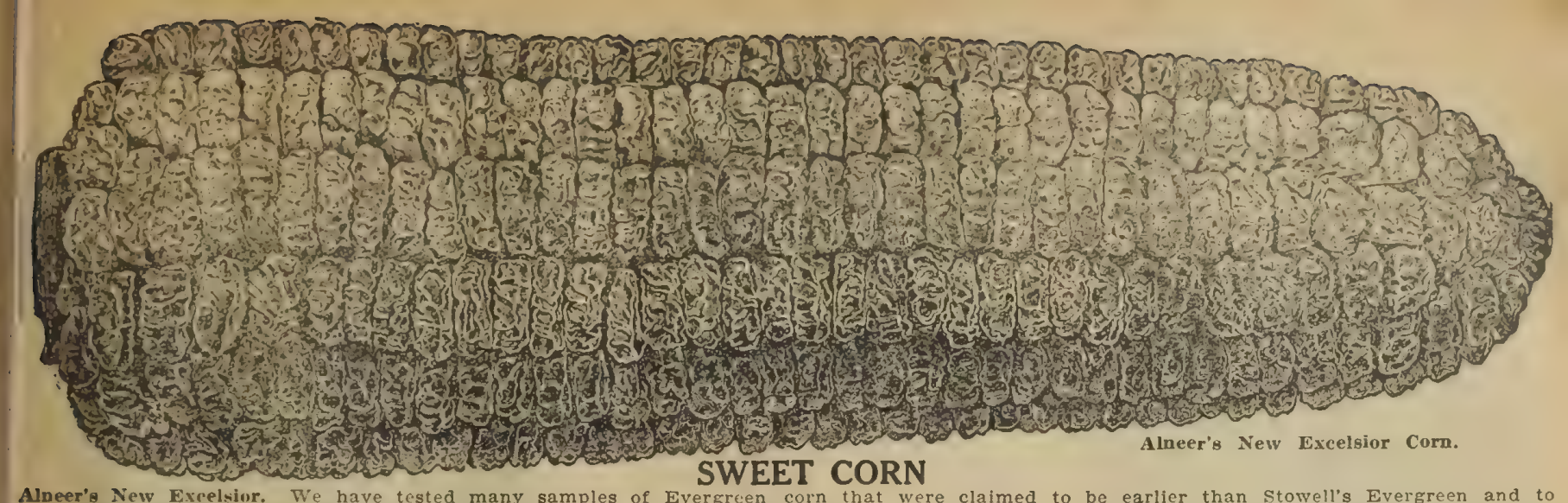

Alpeer's New Froelsior.

\section{SWEET CORN}

trlal grounds and in the fie to

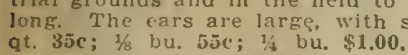

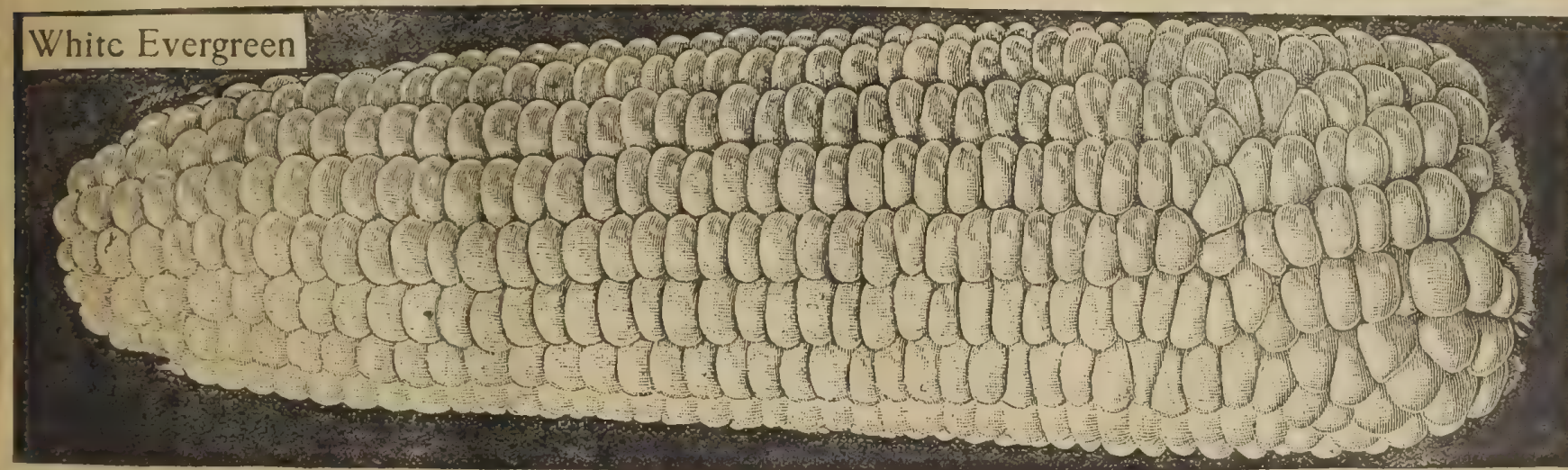

Now White Evergreen. The stalks are of a strong, vigorous growth, 6 to 7 feet high. Ears are very large, well flled to the lip, with long slender grains of the purest whiteness and
most dellcious flavor. Pkt. 5c; $1 / 2$ pt. 10c; pt. 16c; at. 30c; 1/8 bu. 45c; $1 / 4$ bu. 85c; $1 / 2$ bu. $\$ 1.60 ;$ bu. $\$ 3.00$.

Early Golden Bantami. Of extreme hardiness, and can be planted earlier than any other true from three and a half to four feet in height and produce one or two good ears on each are a bright golden yellow. The flavor is exceptionally rlch and
Pkt, 5c; $1 / 6$ pt. 12c; pt. 20c; qt. 30c; $1 / 8$ bu. 55 c; $1 / 4$ bu. $\$ 1.00$.

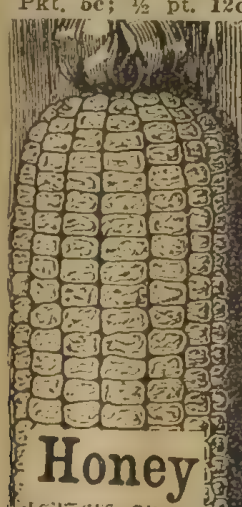

Sweet

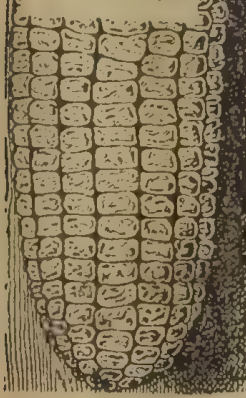

Black Mexican. This corn, when in condition for the table, cooks surpassed by non New

$1 / \mathrm{pt}, 10 \mathrm{c}$ :

Kendel's Early Giant.

measure 8 to 10 inches lon

$25 \mathrm{c} ; 1 / 8$ bu, $40 \mathrm{c} ; 1 / \mathrm{s}$ bue $70 \mathrm{c} ; 1 / 2$ bu. $\$ 1.30 ;$ bu. $\$ 2.50$.

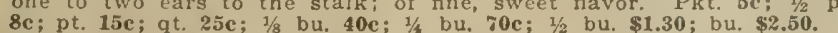

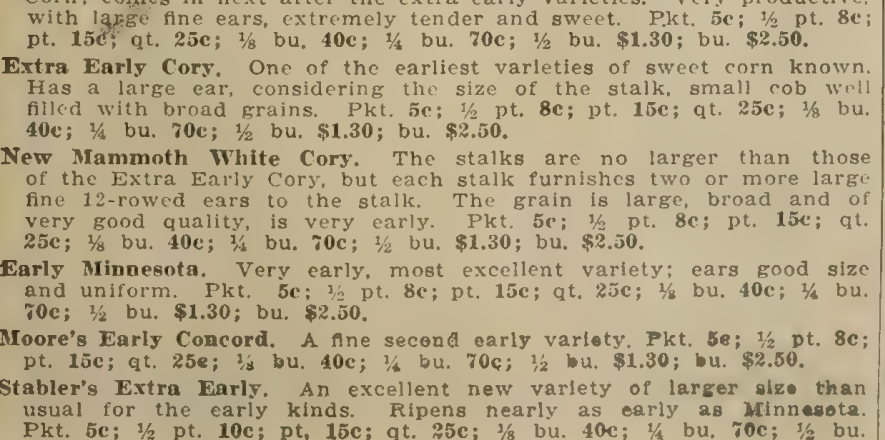

Pkt. 5e; $1 / 2$ pt. 10
$\$ 1.30 ;$ bu. $\$ 2.60$. Early Chicago Market or Ballard.
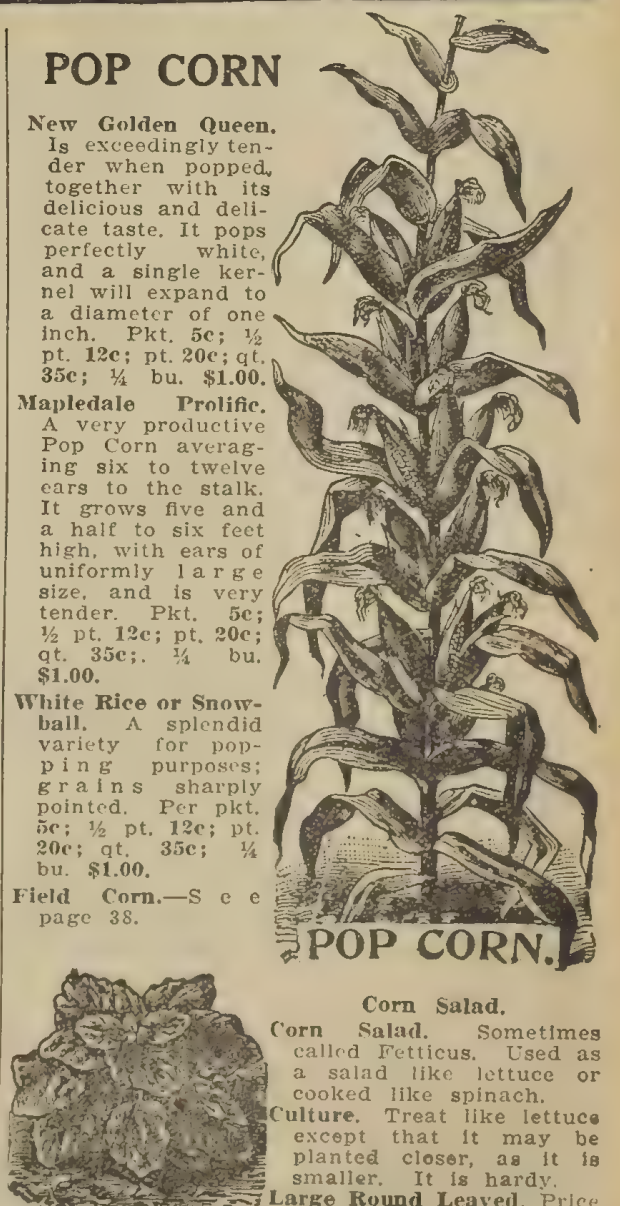

Corn Salad.

CORN SALAD. 


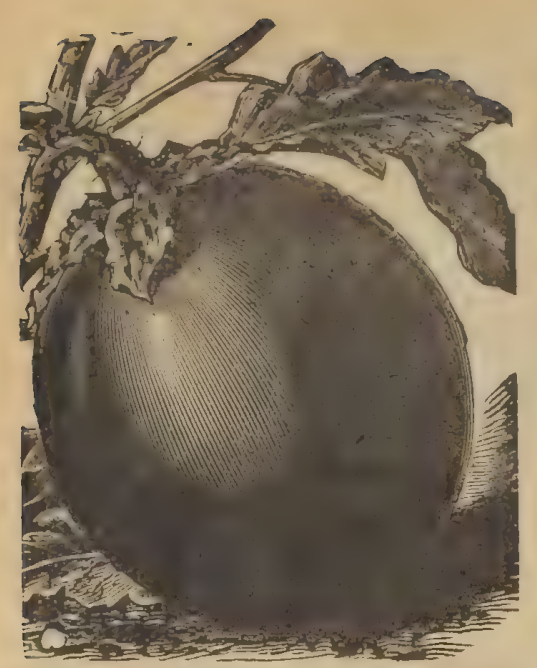

New York Improved Spineless Igg Plant.

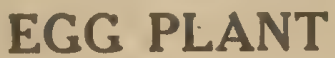

A tender plant Sow in hotbed or

as

New Tork Improved Spineless. The

$18 \mathrm{r}, 1 / \mathrm{k} \mathrm{lb} .66 \mathrm{c}$

Black Pekin. Round, handsome iruit. jet black. Pkt. 4c, oz. $25 \mathrm{c}, 1 / 4 \mathrm{lb}$. 90c.

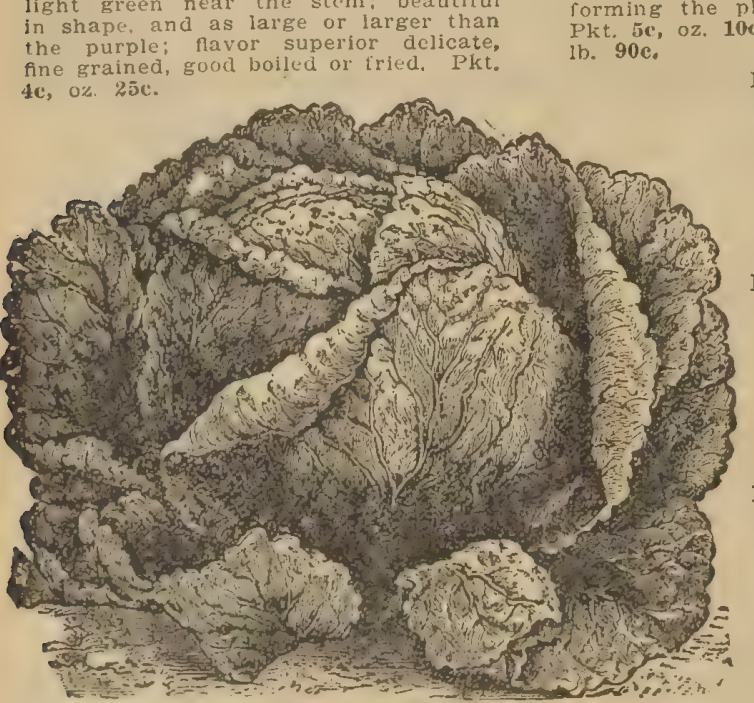

May King Lettuce.

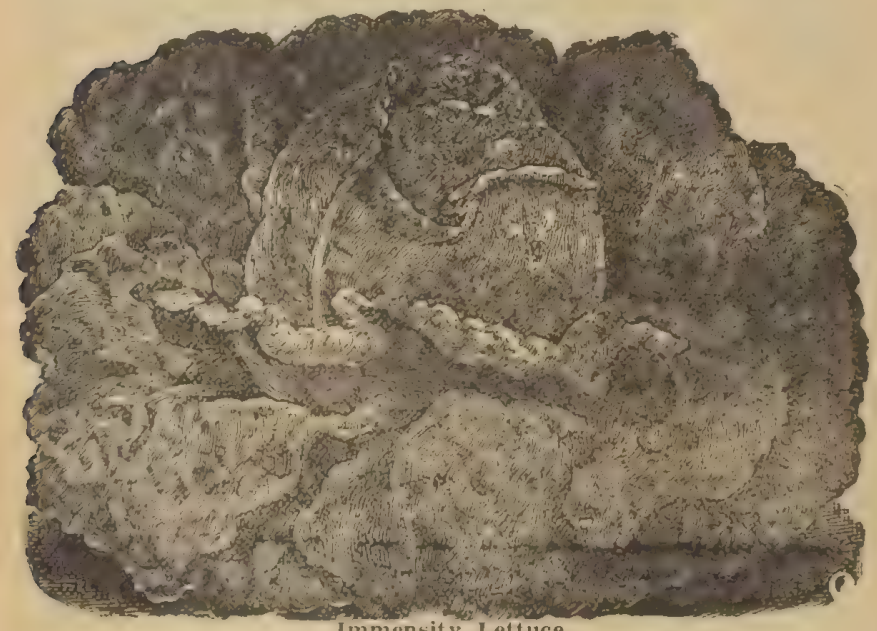

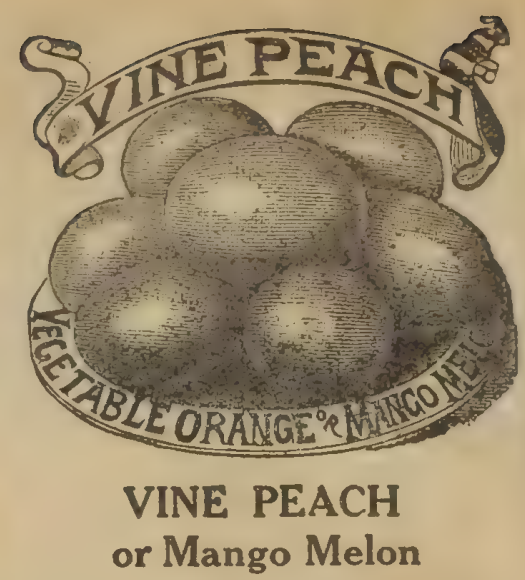

After ripe a short time they become
mellow; for use in any shape. Fine for

\section{LETTUCE}

\section{rich, moist soil Sow}

be prepared, in rows from 12 to 18 inch-

Iay King. A large light green heading lettuce of excellent quality and deor outdoors, It is extremely hardy row six to seven inches in diameter. $1 / 4 \mathrm{lb} .30 \mathrm{c}, 1 / 21 \mathrm{~b}$. 30c, Henderson's New York. A cabbage lettuce that is It forms large solid from 3 to 4 pounds each. It is very crisp and tenBig Boston. Resembles the but is nearly twice as cold frames and for out
door planting. Pkt. 3c
oz. 8c, $3 / 4$ lb. 25c, $1 / 2$ Immensity. Of enormous solid heading, crisp, de Plet. 5e, oz: 8c, $1 / 1 / 1 \mathrm{~b}$ $25 \mathrm{c}, 1 / 2 \mathrm{lb} .40 \mathrm{c}, 1 \mathrm{~b} .75 \mathrm{c}$

California All Heart. Its shape is very distinct, heading a pointed ilmost as solid: of pretty light green shade, almnst white, rich and hutfor both spring and summer use. Plet.5e. oz. 10e, GLIFORNIA
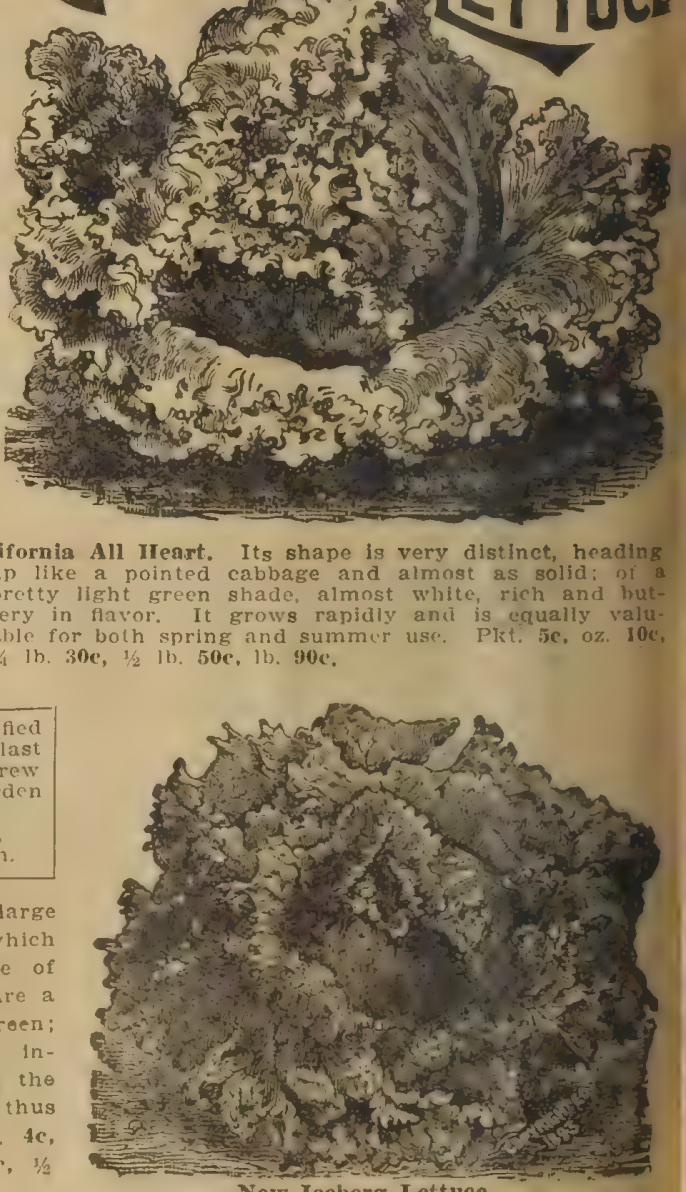

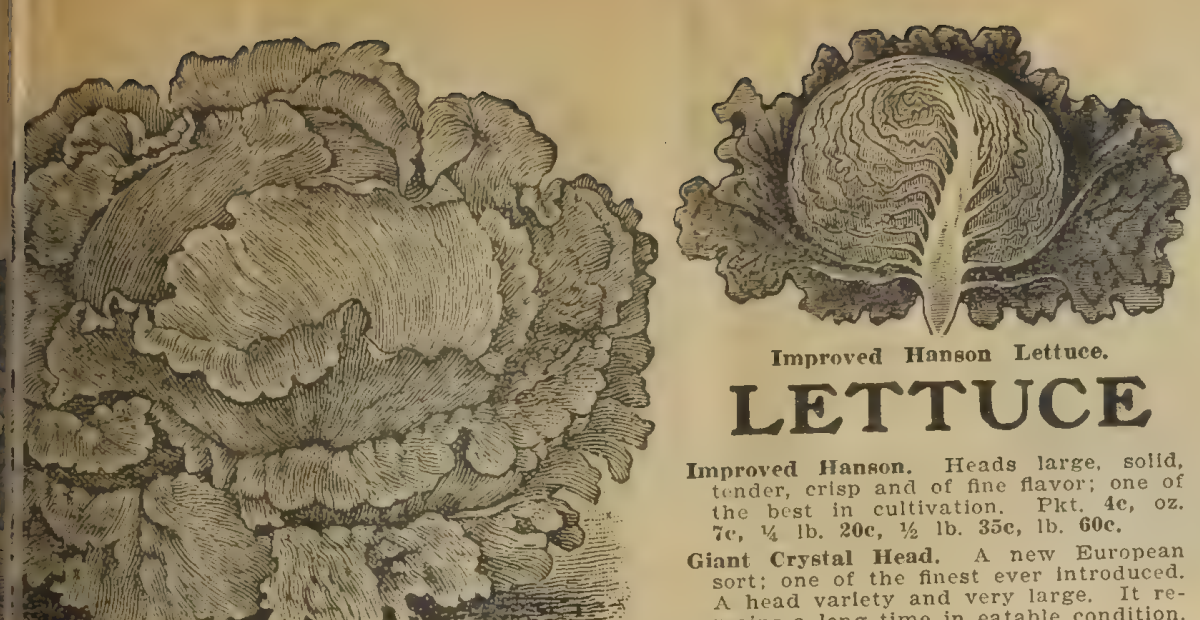

LETTUCE

Improved Ianson Heads larter solid,

Giant Crystal Head.

mains a long time in eatable condition.

Market Gardener's Forcing. Of quick

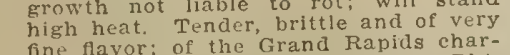

$4 \mathrm{c}$, oz. 8c, $1 / 4 \mathrm{lb}$. 25c, $1 / 2$ lb. $40 \mathrm{c}$, ib. 70c.

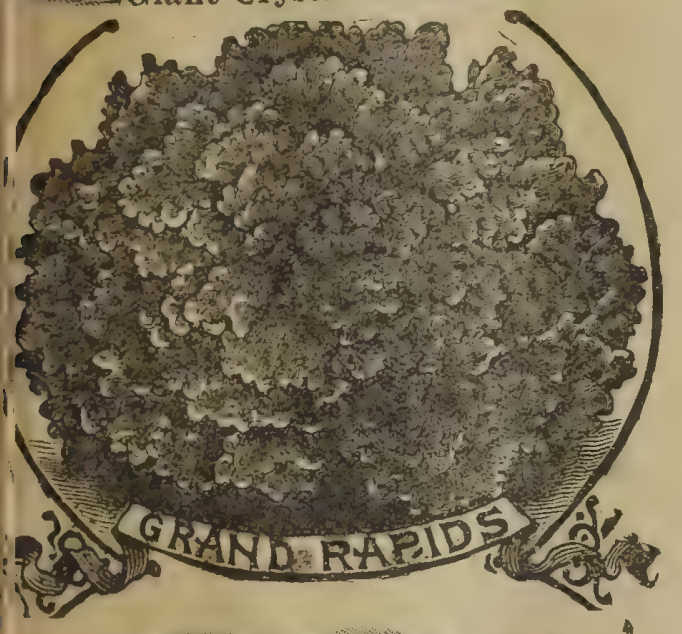

outer leaves are crisp and tender and
remain so throughout the season. Pkt.
3 c, oz, re, $1 / 4$ lb. 20 , $1 / 2 \quad$ lb. 35 , ib. 60c.

Grand Rapids. Of tine quality

cellent forcing sort; a very desirable

ground. Pkt. 3c, oz. 7c, $1 / / 41 b .20 c, 1 / 2$
lb. $35 c$, lb. 60c.
Crisp as Ice. A most beautiful sort. The

heads are solid, of immense slze. The

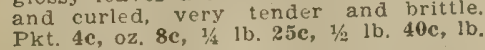

Farly Curled Simpson. The earliest and

lb. 18c, $1 / 2$ lb. 30c, lb. 50c.
Burpee's Tomliannock. The leaves grow very crisp and tender. Is of finest
quality. Pkt. 3c, oz. 6c, 1// 1 b. 18c, $1 / 2$
lb. 30c, 1b. 50c.
California Cream Butter. A head letbest; is crisp and tender. Pkt. 3e, oz. 6c, $1 / 4 \mathrm{lb}$. 20c, $1 / 2 \mathrm{lb}$. 35e, $1 \mathrm{~b}$. 60c.
Self-folding or Paris White Cos. One $\begin{array}{lll}\text { of the best upright sorts, tender and } & \\ & \end{array}$ lb $35 \mathrm{c}, 1 \mathrm{~b}, 60 \mathrm{c}$

Alneer's New Tenderheart. A grand new

large early head lettuce. The large

waxy cream colored heart: leaves o

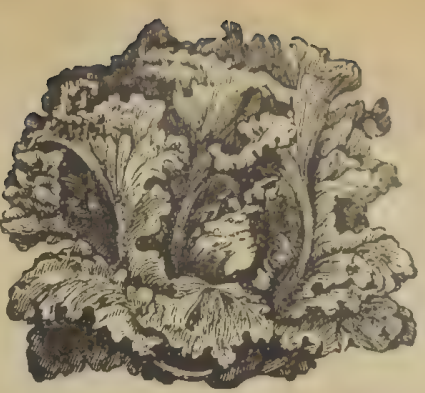

Market Gardener's Forclng.

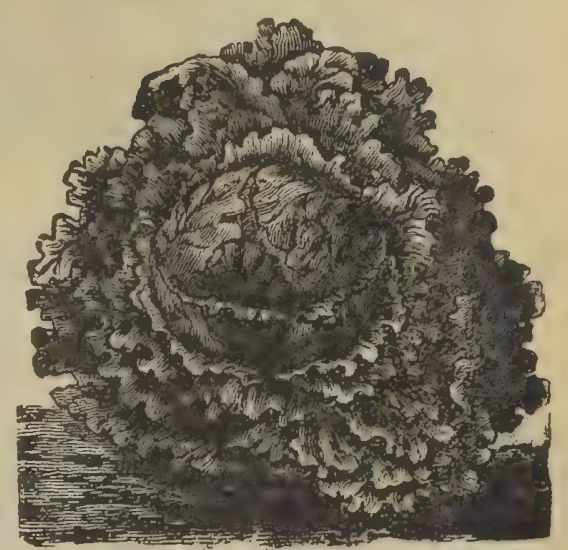

Early Prize Head Lettuce.

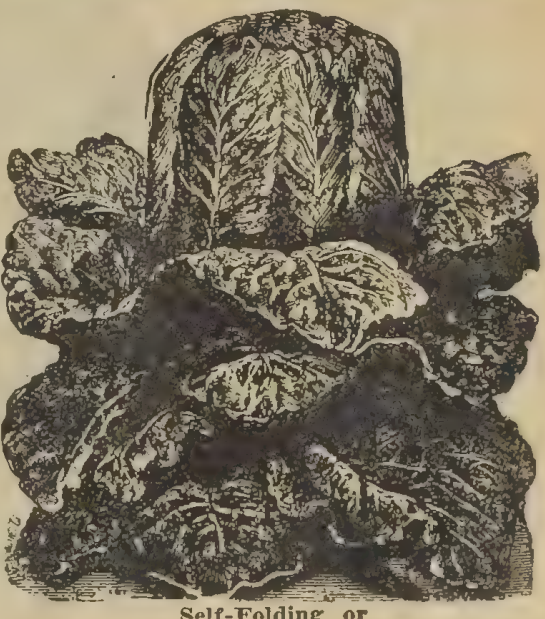

Paris White Cos. Lettuce.

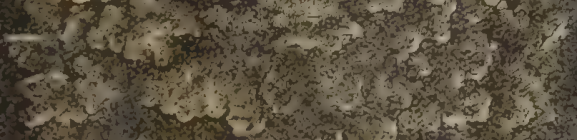

$x^{2}+5,5$

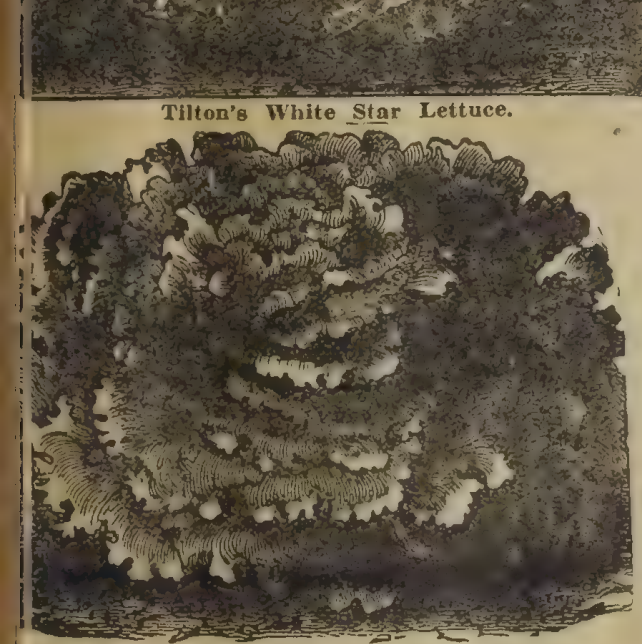

Black Seeded Curled Simpson Lettuce,

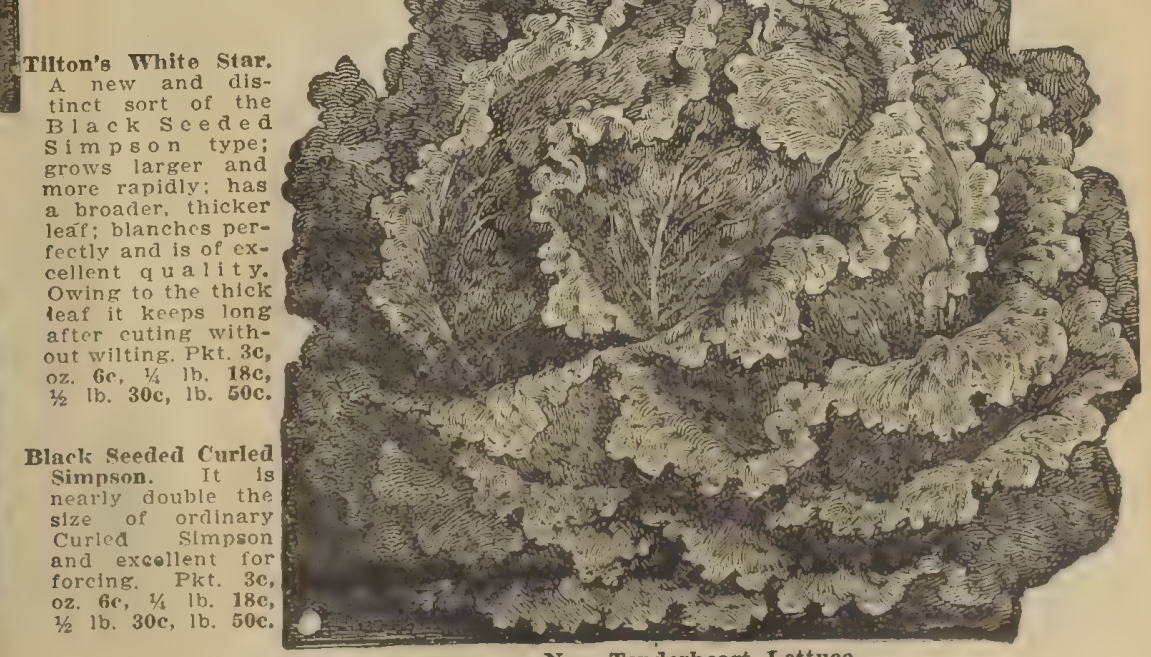

Now Tenderbeart Lettuco, 


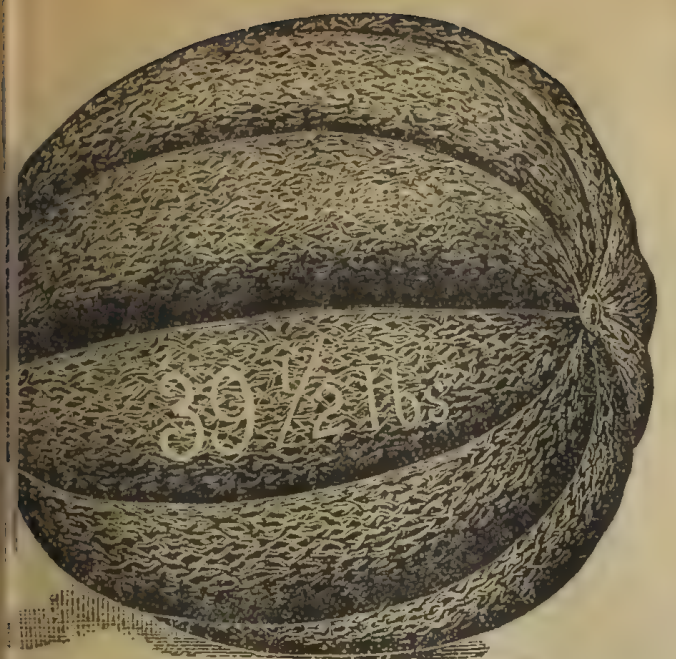

Honey. Grows very unl shape and welghing from 3 to 4 pounds each, skin green and thick ly netted. They are very thick meated, flesh of a light-green color, the inslde surface, when cut open, being of a beautlful green color. In guallty and navor they are superlor, being uniformly rich, sugary and luscious. They are extra Pkt, 5c; oz. 8c; lb. $22 \mathrm{c}$; $1 / 2$ lb. $40 \mathrm{c}$; $1 \mathrm{~b}, 70 \mathrm{c}$ Alneer's Improved Large Nutmeg. Nutmeg shape; flesh green: dellclous flavor, skin finely netted Pkt, 4c; oz. 10c; $1 / 4$ lb. $25 \mathrm{c} ; 1 / 2$ 1b. $45 \mathrm{c}$ 1b. $80 \mathrm{c}$.
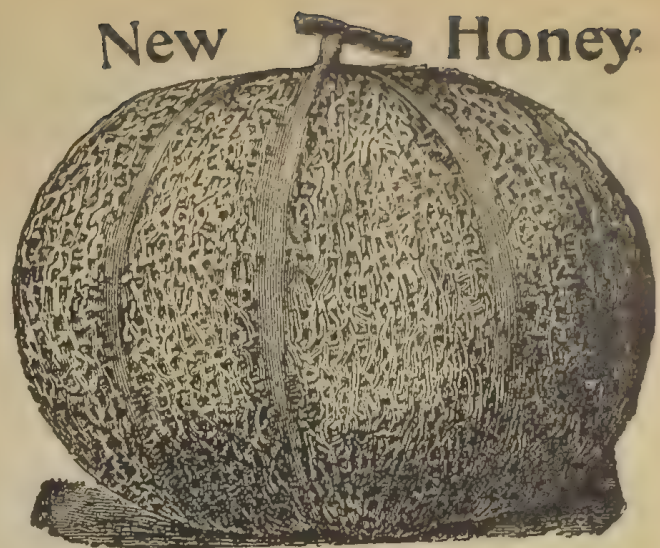

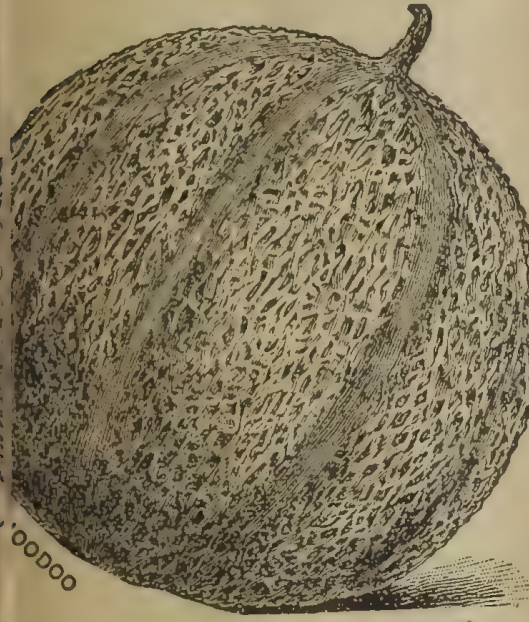

odoo. An ldeal basket and crate melon of nedium size, round, heavily netted, flesh very hick, of rich orange color, handsome appeare ince and of the $11 / 2$ pounds. The seed cavity s mall and the rind is very tough, making fb, $85 \mathrm{c}$; ib. $60 \mathrm{c}$

,-Top. This melon is distinct in appearance. Jur first clalm for it is that it stands at the very tip-top for quality, Sweet, julcy, finest havor; firm but not hard fleshed; very attracUnexcelled in productiveness. Pkt. 4c, oz. 7c; 2/ Ib. 20c; 1/2 lb. 35e; 1b. 60e.
Alneers Improved Large Nutmeg.

Princess. The Princese in shape is nearly round, with heavy netted dark green skin, the flesh is of a rich color, thick, sweet and luscious. Ripens early and grows to good slze. Pkt. 3c: oz. 6c; $1 / 4$ lb. 20c; $1 / 2$ lb. $35 \mathrm{c}$; $1 \mathrm{~b}, 60 \mathrm{c}$

Emerald Gem, The skin is an emerald green the flesh is light red or salmon; very thick, juicy and of the most luscious favor, $20 \mathrm{c}$

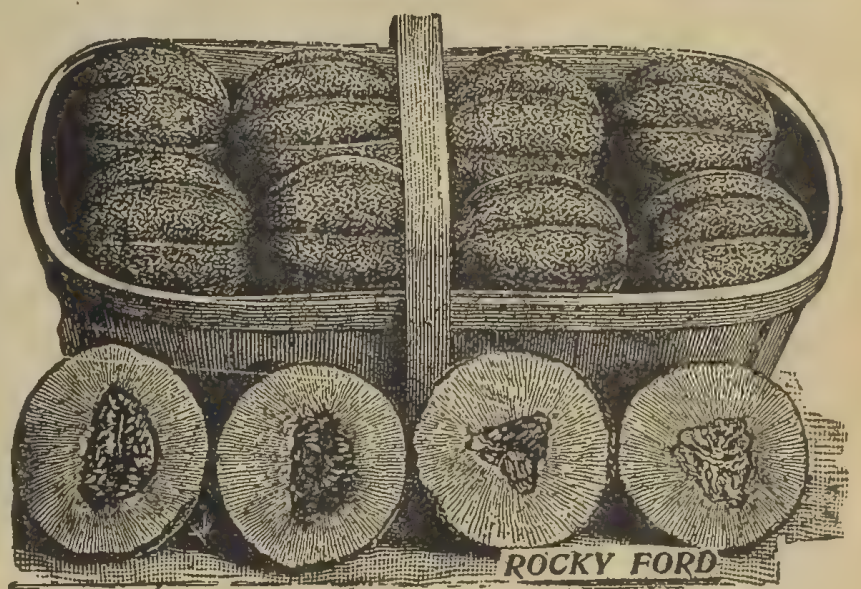
lb. $35 \mathrm{c}$; $1 \mathrm{~b} .60 \mathrm{c}$

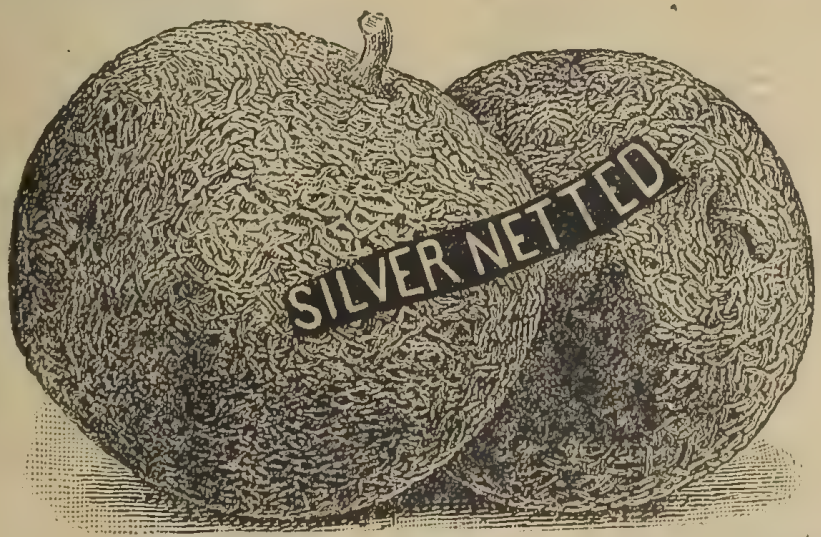

Rocky Ford. Is a greatly imetalning all its good fea tures and growing large and even more armmetrical In shape. Is used largely in hotels and finest Wher have ket Pkt $3 \mathrm{c}$ : $0 \mathrm{z}, 6 \mathrm{c}: \mathrm{y}$ 1\%c; $1 / 2$ ib. $28 \mathrm{c}$; $1 \mathrm{~b}$. 50c. Grand Rapids. A new extra of handsome shape. It is the gardeners on account earliness Pkt. $3 \mathrm{c} ; \mathrm{oz}$. 7c 60c.

Miller's Cream. The flesh Silver Netted Nutmeg. The illustration represent exactly the handsome, heavily sllver netted appearance of this fine melon. The green flesh is verin sweet and melting, $0 \mathrm{c}, 7 \mathrm{c} ; 3 / 4 \mathrm{lb}, 20 \mathrm{c}$ lb. $60 \mathrm{c}$.

Golden Netted Gem. A small early green fleshed variety; very sweet and fine. Pkt. $3 \mathrm{c} ;$ oz, $6 \mathrm{c} ; 1 / 4$ lb. $18 \mathrm{c} ; 1 / 2$ lb. $28 \mathrm{c} ; 1 \mathrm{~b}$. $50 \mathrm{c}$.

\section{MUSHROOM}

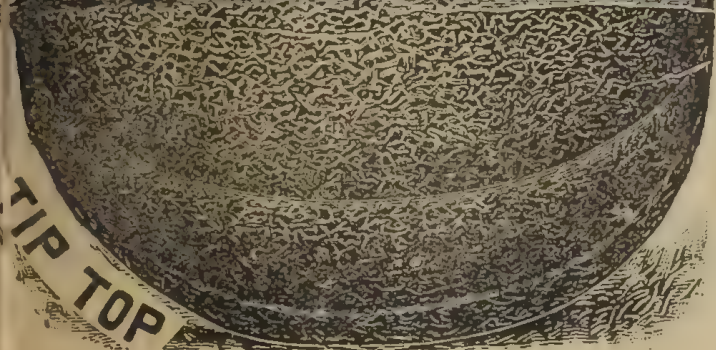
sons, and it is profitable crops to grow.

\section{English Mushroom Spawn}

It come in pressed bricks welghing about 20 ounces. These are broken into pleces the size of a wainut and put into the bed lght inehes apart each way. pald.

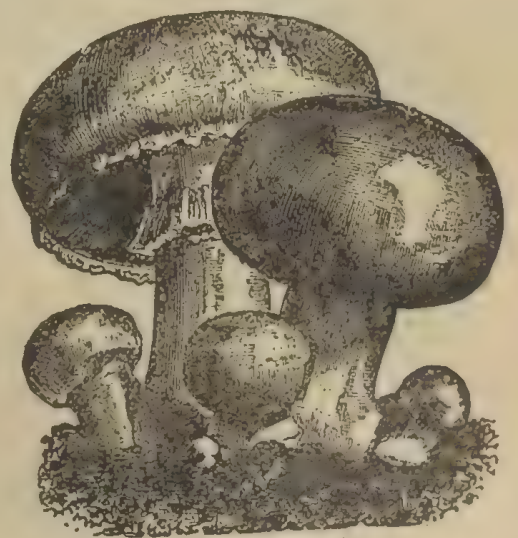

MUSHROOMS 


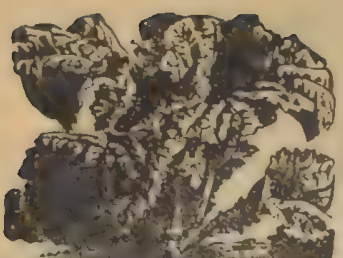

कीजि

GANESE SAUSTARO

\section{MUSTARD}

A pungent salad. Sow thickly in rows six inches

two Inches high.

White London, Pkt. 2c, 15c, $1 \mathrm{~b}, 25 \mathrm{c}$.

Chinese New Giant. Also called "Southern Curled," An excellent new sort.
Pkt. 3c, oz, 6e, 1/4 ib. 18c X/3 Jb. $30 \mathrm{c}, 1 \mathrm{~b}, 50 \mathrm{c}$.

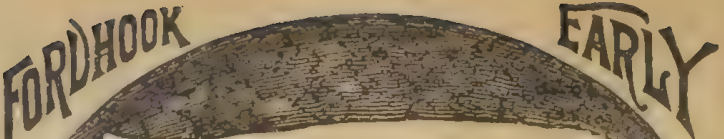

Fordhook Early. Flesh of a deliclous sweet llavor, bright red in color. valuable shipper, Quite similar to Ice Cream, but has a tougher rind. Pkt. $3 \mathrm{e}$,
lb. $40 \mathrm{c}$.

True Ice Cream. (White Seeded.) Medium size oval shaped, flesh bright scarlet, solld, sweet and very delicious. One of the best. $3 \mathrm{c}, 0 z$. 5c, $1 / 4$ lb. 15c, $1 / 21 \mathrm{~b} .25 \mathrm{c}, 1 \mathrm{~b}$ 40e.

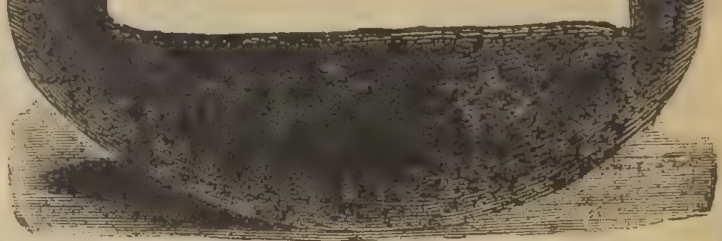

MELON---WATER

Watermelons require a rich, sandy soil. Cultivate as for muskmelon, except that the hills should be six feet apart, each way.

Harris' Earliest. A new early, large melon. Very sweet, delicious and attractive, Has beautiful red core, sweet and melting. Exceedingly productive, Pkt. 4c, oz. $6 \mathrm{c}, 1 / 6 \mathrm{~b}$. $15 \mathrm{c}, 1 / 2 \mathrm{lb}, 28 \mathrm{c}, \mathrm{lb}$. 50c.

Halbert Honey. This new melon equaling in flavor and as handsome in color as Kleckley's Sweets, but more regular in form. They average 18 to 20 inches in length. The fesh is a beautiful crimson, of luscious quality, melting and sweet as horey. Pkt. 3c, oz, 6c, 1/4 lb, 15c, 1/2 lb, 28c, 1b. 50c.

New Columbia, or Dixie. This new melon has a remarkably thin, tough rind, and as a keeper and shipper has no equal. Its productiveness is unequaled. The melons are of a dark green color, oblong in shape, and beautifully striped. Flesh bright scarlet, of flne quality almost down to the skin. Most productive, finest eating best shipper ever introduced. Pkt, 3c, oz. 5c, $1 / 41 \mathrm{~b} .15 \mathrm{c}, 1 / \mathrm{k} 1 \mathrm{~b} .25 \mathrm{c}, 1 \mathrm{~b} .40 \mathrm{c}$.

McIver's Wonderful Sugar. This new watermelon was introduced by Col. E. R. Mclver, the seed coming originally from the West Indies. Of large size and superior quality; sweet as sugar; also extremely
productive and hardy. Pkt. 3c, oz. 5c, $1 / \mathrm{h}$ lb. 15e, $1 / 2$ ib. 25c, 1b. 40c.

Duke Jones, of Jumbo. Color of skin solid green, the flesh is very bright red, particularly sweet, juicy and melting. It grows to a large slae, sometimes attaining the weight of 80 pounds. In shape It resembles Kolb's Gem, and like that variety, is one of the best shlpping sorts, Pkt. 3c, oz. $5 \mathrm{c}, 1 / 41 \mathrm{~b}$. 15c, $1 / 2$.

Sweet Heart (New). Vigorous and productive, ripening its fruit early; frult large, oval, very heavy, uniformly mottled light and dark green; rind thin but firm, flesh bright red, firm, solid, very tend
melting and sweet. Pkt. 3c, oz. 5c, 1/4 1b. 15c, $1 / 2,1 b .25 c, 1 b .40 c$. Improved Kolb's Gem. Skin dark green, marbled delicately with lighter shades: size large an- unlform, weighing from 35 to 70 pounds, although selected spccimens reach greater weights; flesh tender, melting and of uns
oz. 5c, $1 / 4 \mathrm{lb}, 15 \mathrm{c}, 1 / 2 \mathrm{lb} .25 \mathrm{c}, 1 \mathrm{~b} .40 \mathrm{c}$.

New Triumph. The New Trlumph is a cross between the Duke Jones and Kolb Gem, having the handsome dark green color of the former and fine shipping qualities of the latter; early 50 to 75 pounds. Pkt, 3c, oz, 5c, 1// lb, 15c, 1/2 lb, 25c, lb. 40c. Gypsy, or Georgia Rattlesnake. Very large, nislong, striped; flesh

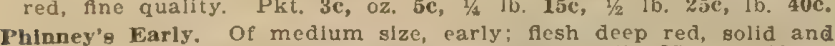
Pkt. 3c; 0z. 5e; $1 / 3$ lb. 15c; $1 / 2$ lb. 25e; $1 \mathrm{~b} .40 \mathrm{c}$

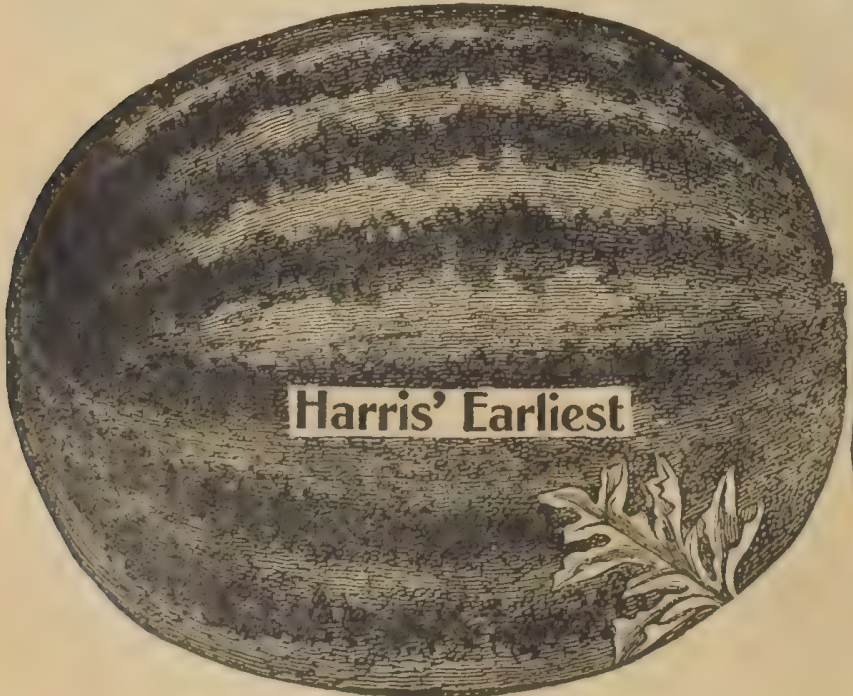

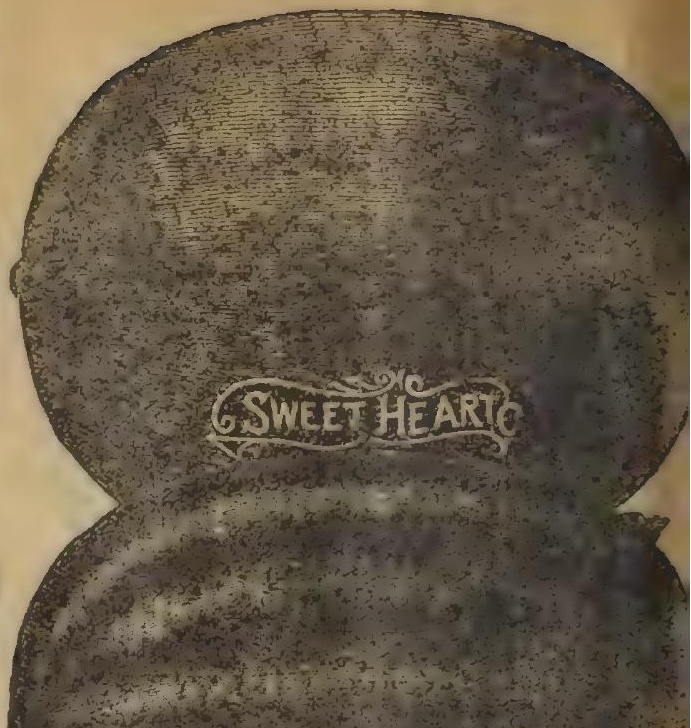

6.

C.

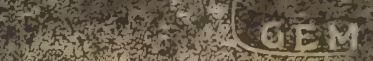

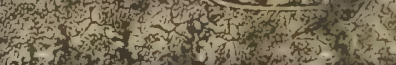

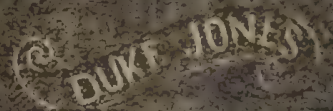

\section{Halbert Honey}




\section{KLECKLEY "SWEETS"}

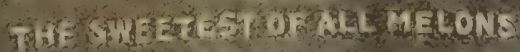

Mountain Sweet. Fruft oblong, sweet Pkt. $3 \mathrm{c} ; 0 z .5 \mathrm{c} ; 1 / \mathrm{kb}$.

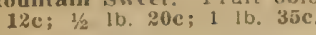

Mammoth Gray Monarch. Attalns a welght of 60 pound gray color: shape Pkt. 3e; oz. 5e; 1/4 1b. 15e; 1/2 1b. 25e; $11 \mathrm{~b} .40 \mathrm{c}$.

Semiole. Flesh is a brilliant carmine, very solld, of a rich

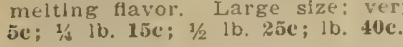

Cltron. Esed for making preserves and sweetmeats. Pkt. $3 \mathrm{c} ;$ oz. $5 \mathrm{c} ; 1 / 4$ Ib. $15 \mathrm{c} ; 1 / 2$ b. $25 \mathrm{c} ; 1 \mathrm{~b} .40 \mathrm{c}$.

The Wonderful Japanese Pie Melon. Makes dellclous preserves and savory ples, requining very litele sugar. Pkt. $3 \mathrm{c} ;$ oz. 5c; $3 / 1 / \mathrm{lb}$. 15c; $3 / 2$ lb. 25e; $1 \mathrm{~b} .40 \mathrm{c}$.

Iammoth Ironclad. They grow uniformly very large, nesh is extremely $5 \mathrm{c} ; 1 / 4 \mathrm{lb}$. 12c; $1 / 2 \mathrm{lb}, 20 \mathrm{c} ; 1 \mathrm{~b}$. $35 \mathrm{c}$.

Watson

ileckley's Sweets" Watermelon. Are the T010 long shape, dark green skin; bright red flesh, always solid and of the most lusclous flavor imaginable. The only fault we discover is that the rind is too tender for the melons to ship well to distant markets, but for the home garden and local market no other melon can equal the "Kleckley Sweets," Pkt. 4c; oz. 7c; 1/4 lb. 17c; 1/2 lb. $28 \mathrm{c} ; 1 \mathrm{~b} .50 \mathrm{c}$.

abama sweets. A grand new melon. It is a large, beautifil shaped melon, the skin is tough and is not injured by hand:ing, nor shipping. It is one of the best and sweetest sorts ever grown. It is well adapted to the north because it is not as late as many of the large varieties. Plst. sc; oz. $6 \mathrm{c} ; \mathrm{y} / \mathrm{lb}$. $15 \mathrm{c} ; 1 / 2 \mathrm{lb}$. 25c; $1 \mathrm{~b} .40 \mathrm{c}$.
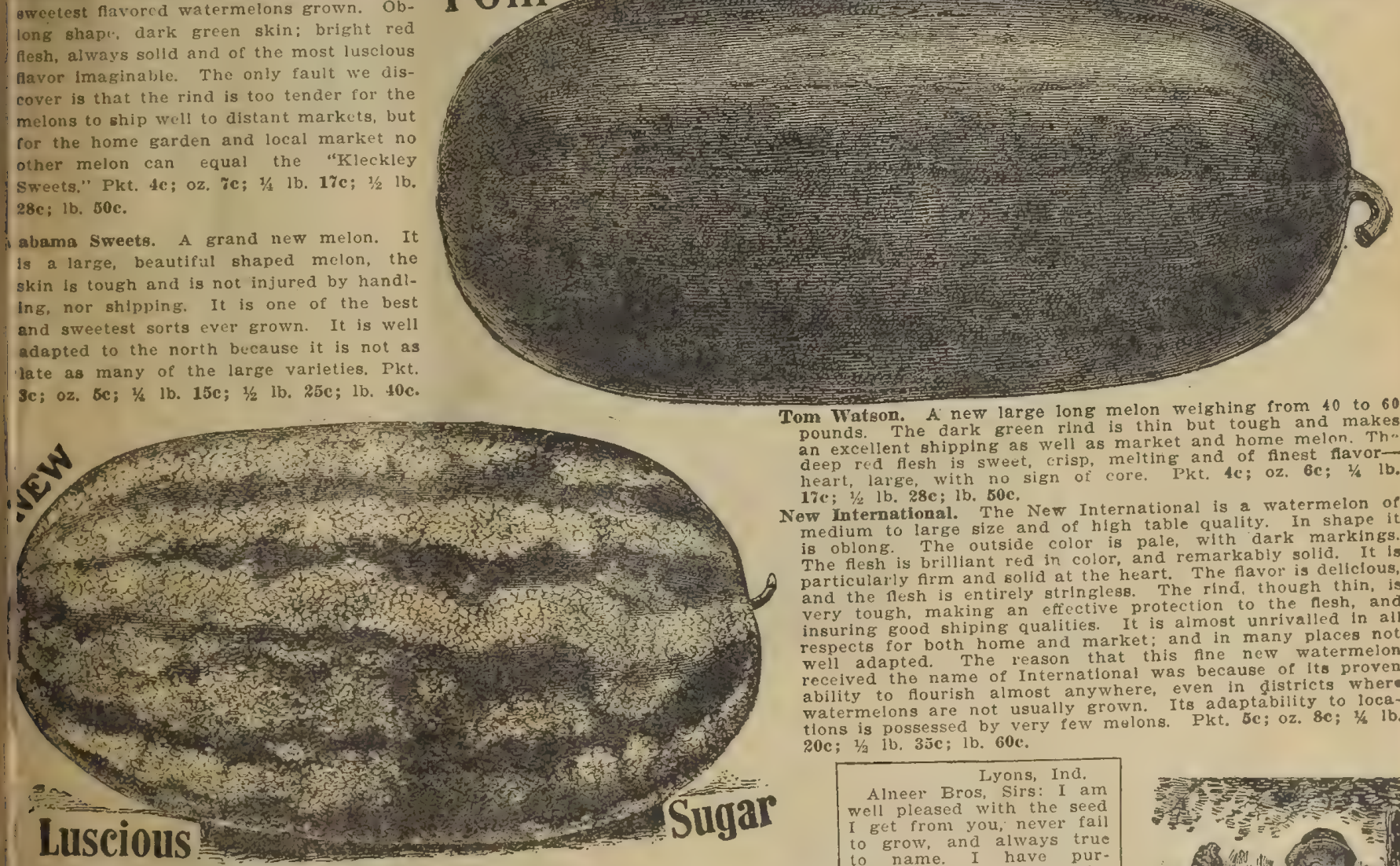

Tom Watgon. A new large long melon welghing from 40 to 60 pounds. The dark green rind is thin but tough melon. Th. an excelient shipping as well as market and home mel flavorheart, large, with no sign of core. Pkt. 4c; oz. 6c; $1 / 4$ lb. 17e; $1 / 21 \mathrm{~b}$. 28c; $1 \mathrm{~b}, 50 \mathrm{c}$.

New International. The New International is a watermelon of medium to large size and of high table quality. In shape it is oblong. The outside color is pale, with dark markings. The flesh is brilliant red in color, and remarkabiy solld. It is The fiesh is frm and solid at the heart. The flavor is deliclous, pand the flesh is entirely gtringless. The rind, though thin, is very toun making an effective protection to the flesh, and insuring good shiping qualities. It is almost unrivalled in all respects for both home and market, and in many places not well adapted. The reason that this fne new watermen recelved tho name of International was because of ist ability to flourish almost anywhere, even in aisility to locawatermelons are not usually grown. Its $5 \mathrm{c} ; 0 \mathrm{z}, 8 \mathrm{c} ; \mathrm{H} / \mathrm{lb}$ $20 \mathrm{c} ; 1 / 3$ 1b. $3 \mathrm{jc}$; $1 \mathrm{~b} .60 \mathrm{c}$

few Luscious Sugar. This splendid large melon, as shown in this Illustration, is oblong in shape. The tough skin is very dark green, with lighter strlpes; flesh is dark red in color, fine grained; sweet and luscious, entirely free of stringness. A first class shipper; under good cultivation they grow to a very large size, frequently weighing from 30 to 60 pounds, and commanding the very hlghest prices in the market. Pkt. 5c; oz. $8 \mathrm{c} ; 1 / 4$ lb. $20 \mathrm{c} ; 1 / 2$ ib. $35 \mathrm{c}$ Ib. $60 \mathrm{c}$.

Juban Queen. Grows to a mammoth size, not unusual for specimens to reach 80 pounds, and is an enormous yielder. The skin is beautifully striped light and dark green; flesh unsurpassed, bright rea, solid and of most de 25c; $1 \mathrm{~b}, 40 \mathrm{c}$.

Florida Favorite. A new early melon, Size medium to large; sweet and delicious In flavor, $1 / 61 \mathrm{~b} .15 \mathrm{c} ; 1 / 2$ lb. $25 \mathrm{c} ; 1 \mathrm{~b} .40 \mathrm{c}$.

Black Diamond. Most distinctive point is its color, rich dark green aimost black. Uniform shape, everaging from 35 to 50 pounds each, very productive. Flesh bright red and delicious flavor
Pkt. 3c; oz. 5c; $1 / 1 \mathrm{~b}, 12 \mathrm{c} ; 1 / \mathrm{s}$, $20 \mathrm{c} ; 1 \mathrm{~b}, 35 \mathrm{c}$.

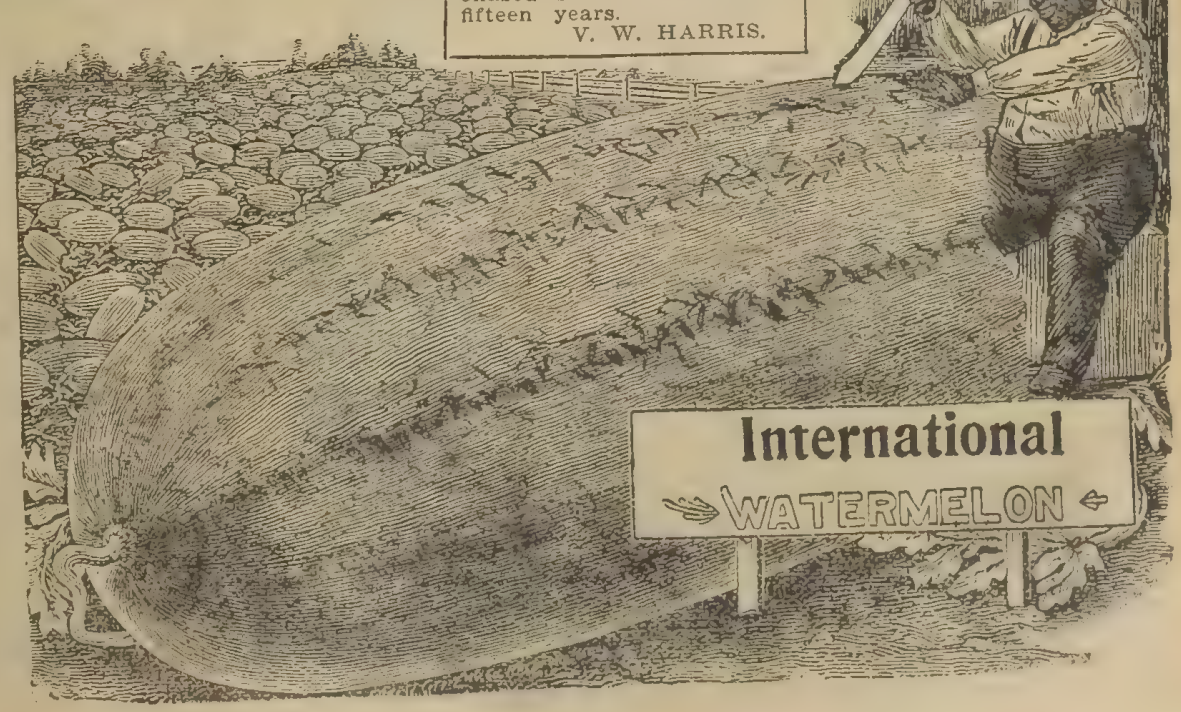




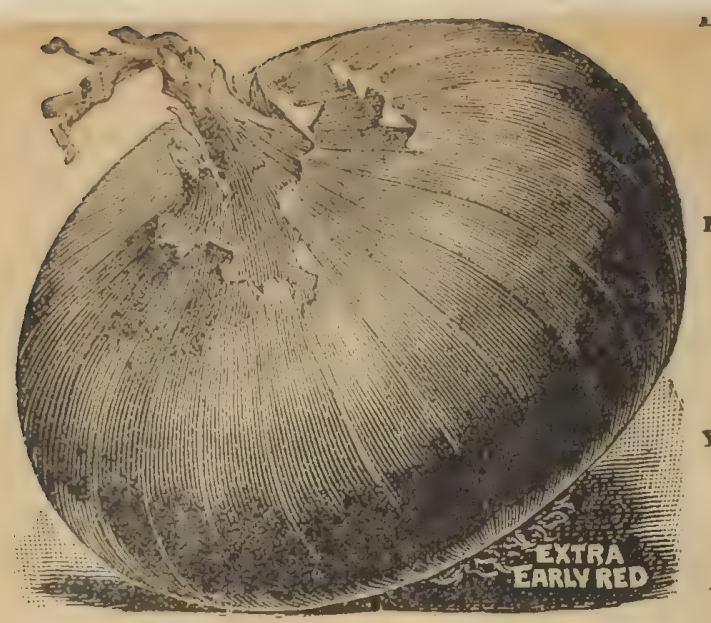

warge nea weineranela.

The staple variety of

the red sorts; large

deep in color:

$4 c$; oz. $7 \mathrm{c} ; 1 / 4 \mathrm{lb}, 23 \mathrm{c}$;

$1 / 21 \mathrm{~b}, 40 \mathrm{c} ; 1 \mathrm{~b}, 75 \mathrm{c}$.

Round Yellow Danvers.

A fine straw-colored sort of mild flavor, rlpens early; good keeper. The staple sort. Pkt. 3c; oz. 8c; 1b. $80 \mathrm{c}$.

Yellow Danvers Globo. Form globular; beaucolor, mild flavor and a good keeper. One of the best taple sorts. Pkt, $3 \mathrm{c}$; oz. 8c; Ib. 800 .

\section{ONIONS}

In the spring as early as the ground can be prepared, sow seeds in drllls 15 inches apart. When the young plants are strong enough thin apart. Four pounds of seed or more are usually sown to the acre. As soon Keep clean until ripe.

\section{Alneer's Superior Onion Seed} Wo make ontons one of our grown from selected bulbs only. Vitality critically tested before sent out, hundred bushels of fine, large, handsome onions to the acre. Take no buy from us and get the best that grow

Extra Early Red. Ripens about ten days earlier than the Wethersfield,

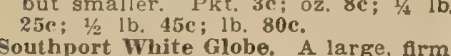
Southport White Globe. A large, firm globe-shaped variety, white skin
fne flesh, handsome shape and good keeper, Pkt. 4c; oz. 12c; $1 / 4 \mathrm{lb}$ $45 \mathrm{c} ; 1 / 2$ lb. $80 \mathrm{c} ; 1 \mathrm{~b} . \$ 1.50$

Alneer's Selected Yellow Globe Danvers. The finest, largest and best onion of the yellow sorts. Form low color, mild flavor, large size 800 bushels to the acre. Seeds are all grown from selected bulbs. Pkt. $9 \mathrm{c} ; 1 / 4 \mathrm{lb} .30 \mathrm{c} ; 1 / 2 \mathrm{lb} .50 \mathrm{c}$
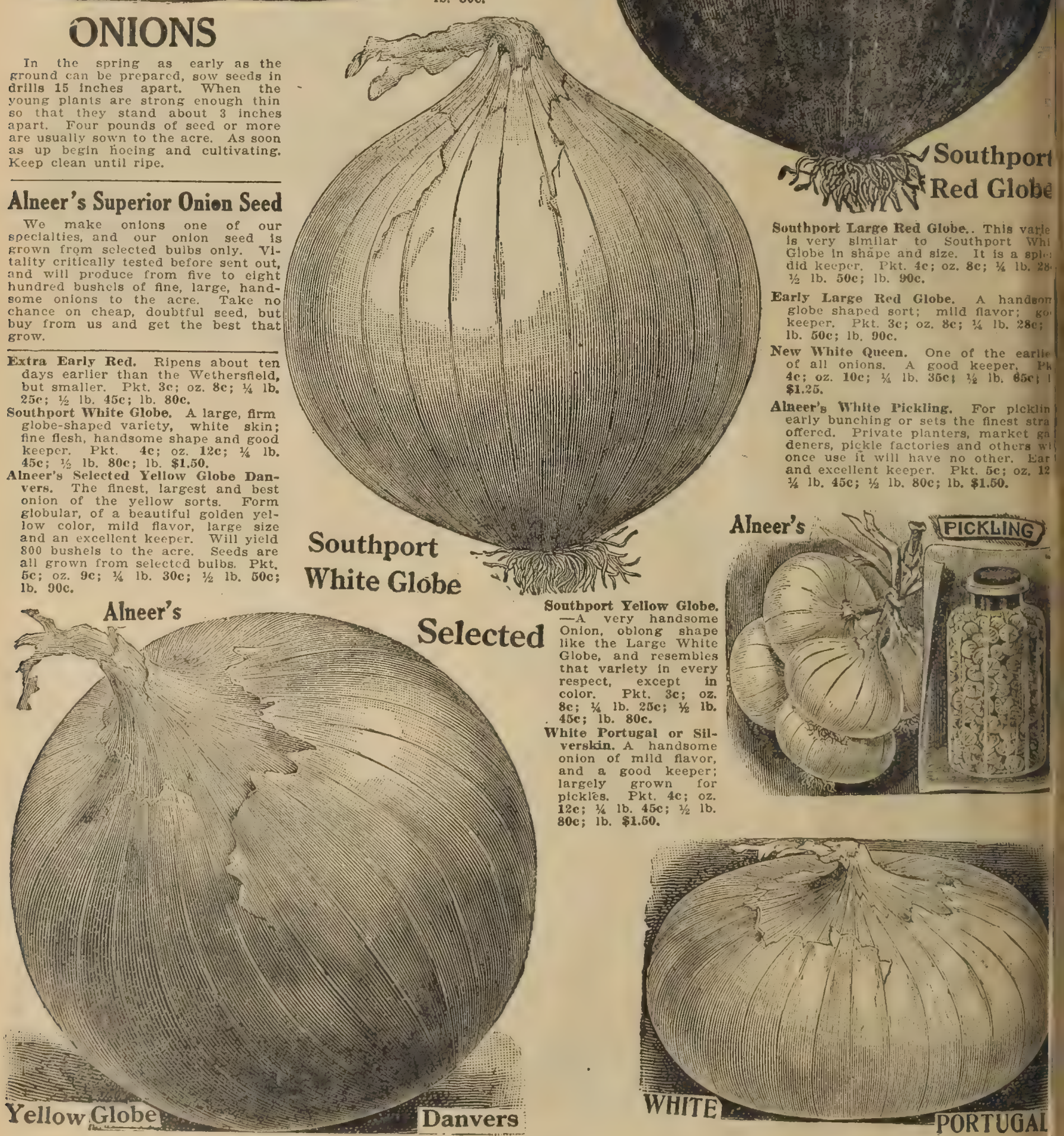

Suthport Large Red Glube. This varte is very simllar to southport tWhi did keeper, Pkt. 4c; oz, 8c; 1/4 1b, $2 b$. 1/2 1b. 50c; Ib. $90 \mathrm{c}$

Early Large Red Globe. A handson keeper, Pl sort; mild flavor: s 1b. $50 \mathrm{c} ; 1 \mathrm{~b}, 90 \mathrm{c}$

New White Rueen. One of the earlis of all onions. A good keeper ph

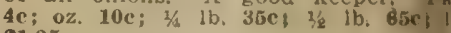
$\$ 1.25$.

Alneer's White Pickling. For plcklin early bunching or sets the finest stra offered. Private planters, market ga once use it wlll have no other. Lar and excellent keeper Pkt 5e: oz 12 $1 / 4$ lb. $45 \mathrm{c} ; 1 / 3$ 1b. $80 \mathrm{c} ; 1 \mathrm{~b}, \$ 1.50$.

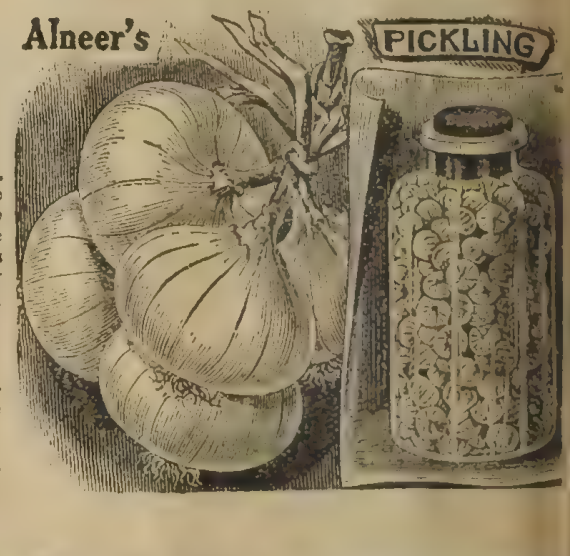

Southport Yellow Globe.

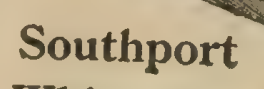

Southport

White Globe

- A very handsom like the Large White Globe, and resembles that varlety in every respect, except in $8 \mathrm{c} ; 1 / 4 \mathrm{lb} .2 \mathrm{be} ; 1 / 2 \mathrm{lb}$. $45 \mathrm{c}$; 1b. $80 \mathrm{c}$.

White Portugal or Silvershin. A handsome onion of mlld flavor. and a good keeper largely grown for pickles Pkt 12c; $1 / 6$ lb. $45 \mathrm{c} ; 1 / 2 \mathrm{lb}$ $80 \mathrm{c} ; 1 \mathrm{~b} . \$ 1.50$.

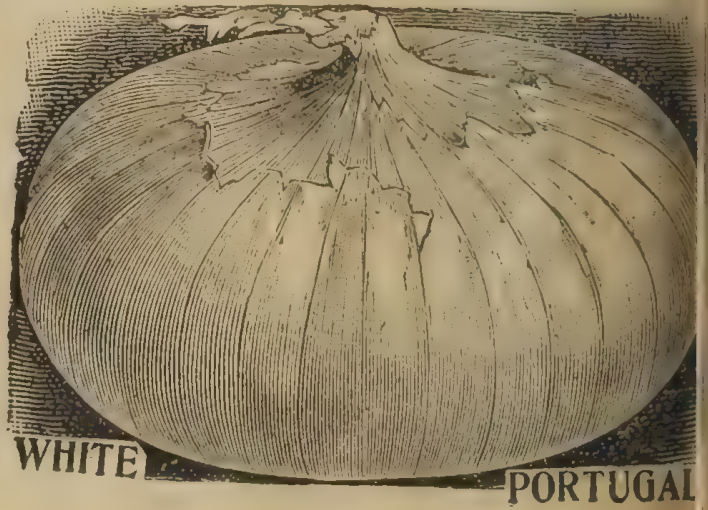




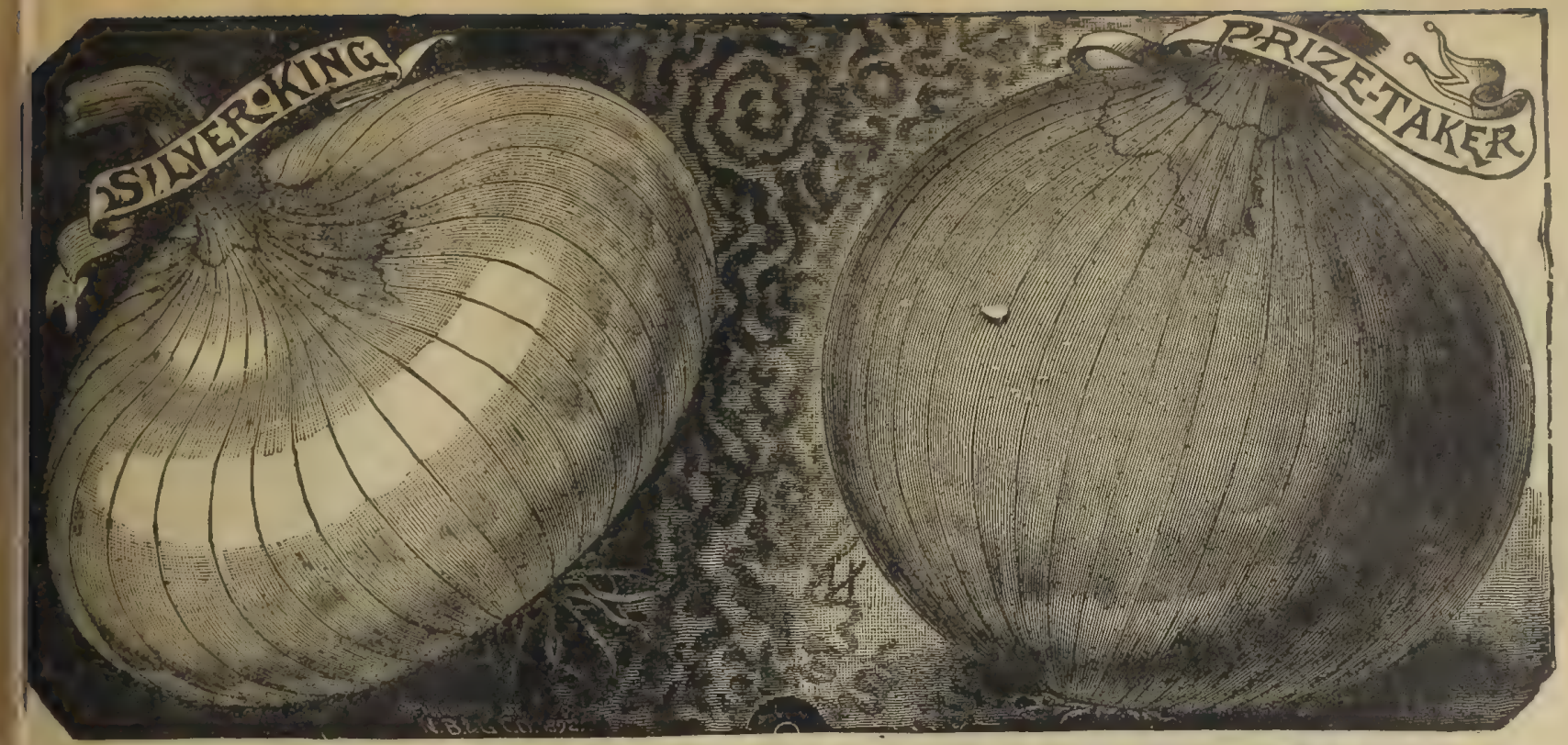

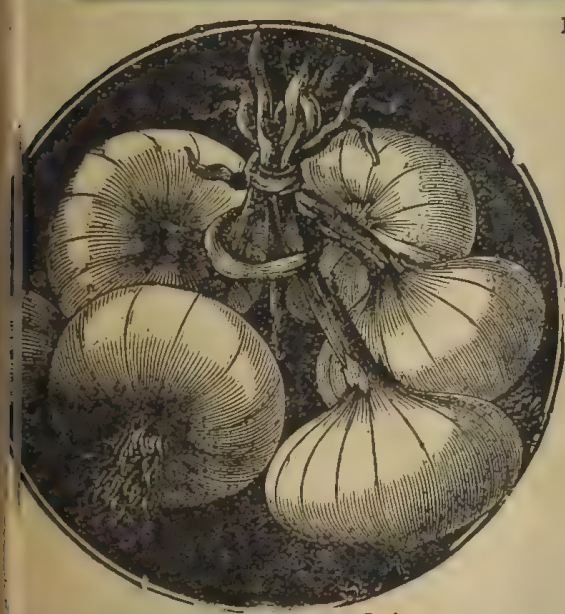

Early White Barletta Onion. early pure white variety. The onions have a very lellcate sllver skin; flesh is firm and mild in flavor, But its greatest mert. others is its extreme earliness. Pkt. 4c, oz, 10c, 1/4 1b. 35e, 1/2 1b. 65e, $1 \mathrm{c}$, $\$ 1.25$, onion; neer's Selected Large Red Wethersfleld. Our cholcest selection of ths I'kt. 5c, oz. 8c, 1/ carefully selectea: will pro

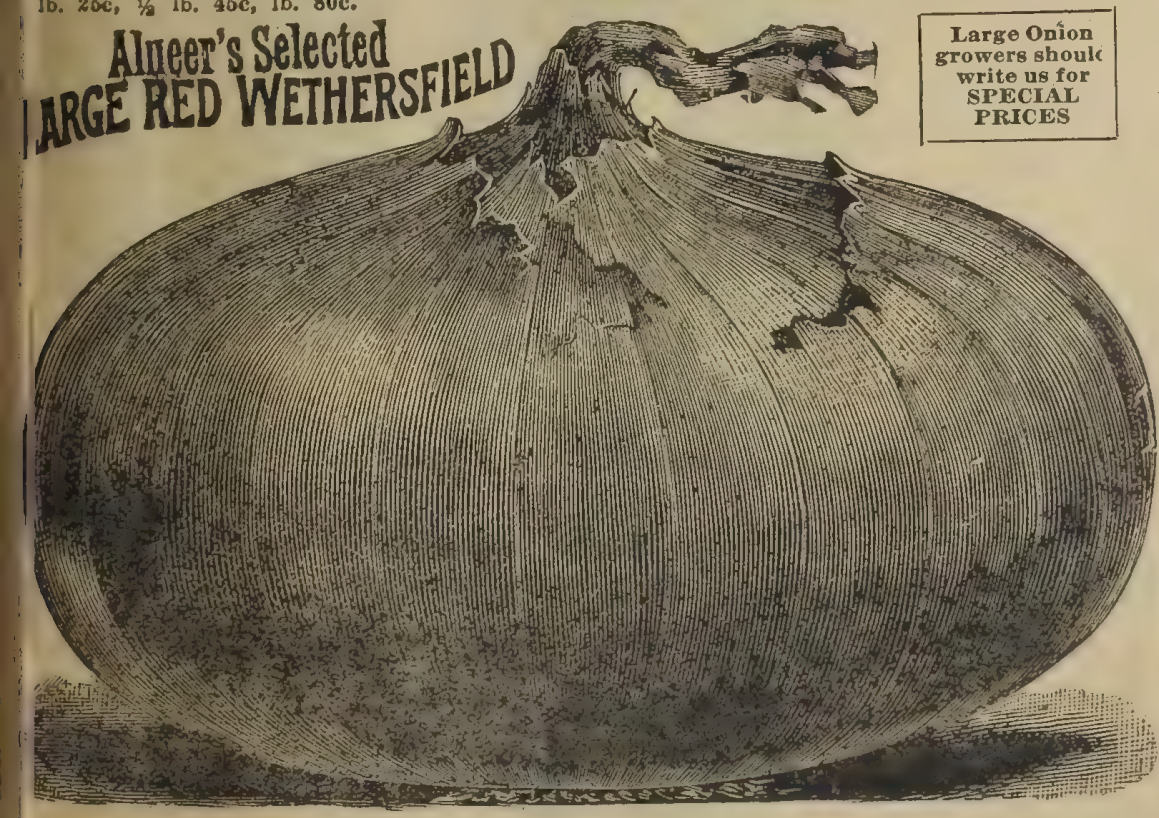

Gentlemen: Having had very good success with all your seedg that we have used, Gentlemen: Having had very good guccerethin irand.-Mrs. George Dayton, Toronto, Kan.

Mammoth Prize Taker. This is the large beautiful Spanish onion that is offered for sale in the fruit are of enormous size, averaging from fourteen to sixteen inches in circumference. Althoug very good winter keeper. Tho outside skin is of a rich yellow color, while the flesh is white, sweet and tender. In marreadily at hish prices. Pkt, 4c, oz, 9c, $1 / 4$ lb. $30 \mathrm{c}, 1 / 2 \mathrm{lb} .50 \mathrm{c}, 1 \mathrm{~b}, 90 \mathrm{c}$.

Mammoth Silver King. Of mammoth size, single bulbs often attain three or fou ful silvery whity the flesh is snowy white and particularly mild and pleasant flavor. It cannot be too highly recommended. $\$ 1.25$.

Mammoth Spanish King, The outside skin is of a rich yellow color, while the flesh is white, and so sweet, mild an an apple. that they can be a package of the wonInclude at least a pang in your order. Pkt. derful Spanish King in $1 / 2$ lb. 50c, 1b. 90c. 4c, oz. 9c, $1 / 41$ b. $30 \mathrm{c}, 1 / 2$ lb. 50c, $1 \mathrm{~b}$.

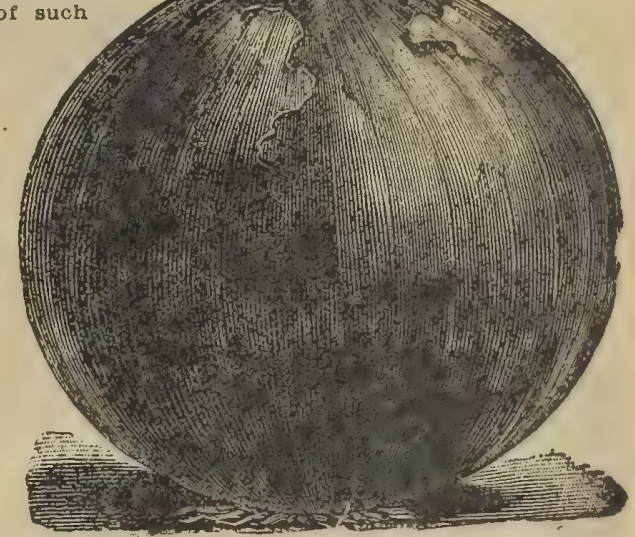

Alneer's New Crimson Globe.

Alneer's New Crimson Globe. The skin of this beautiful onlon is a glossy, deep purplish red color: flesh close-grained, sparkling white; mild and tender. It grows to an immense size. It is keeper the most hardy onions grown ander good culture from 800 to 1,000 bushels per acre. Large 1b. 38e, $1 / 2$ lb, $75 \mathrm{c}, 1 \mathrm{~b}, \$ 1.40$. ustralian Brown. Introduced from Australia. Is of medim size, wondertet: wlll keep in good most attractive for market, other onion known. condition is a almost indefinitely. The Pkt, 3c, oz. 8c, $1 / 41 \mathrm{~b}, 25 \mathrm{c}$, $1 / 2$ lb. $45 \mathrm{c}, 1 \mathrm{~b}, 80 \mathrm{c}$.

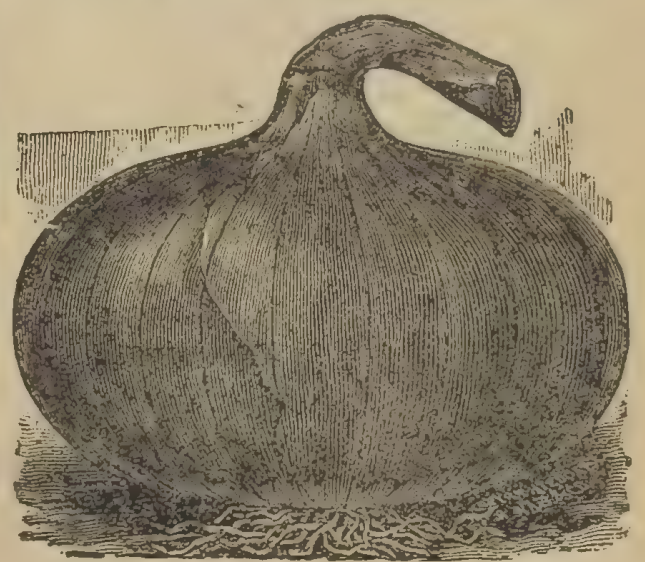




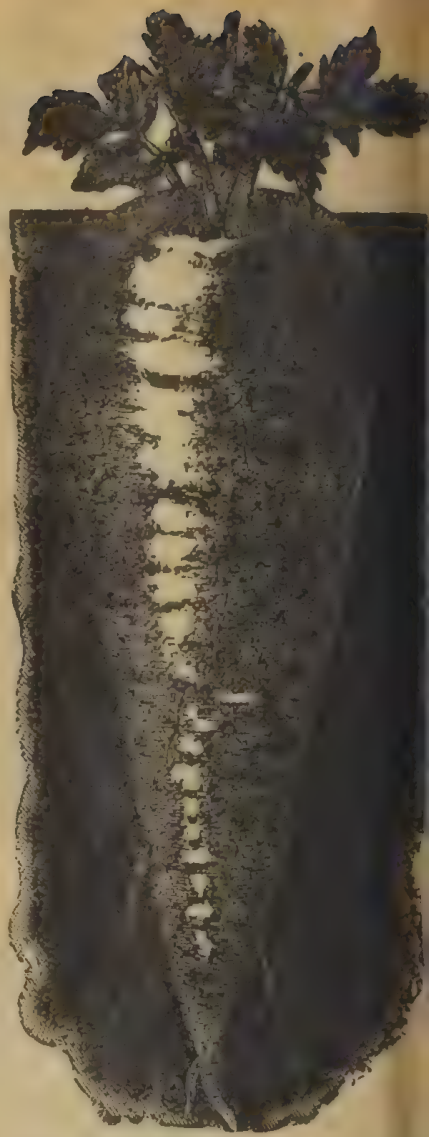

ONION SETS

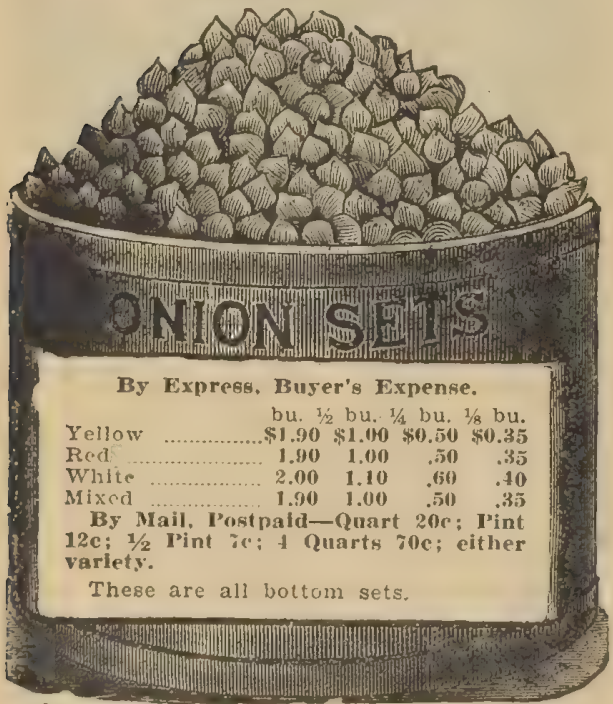

\section{PARSLEY}

Alneer's Fmerald Beauty. Prettlegt curled fringed Bort growing.

Double Moss Curled. A fine dwarf variety, excellent for garnlshing.

Ferm-leaved. Beautiful fern-leaved varlety, very the for table decoration.
$25 \mathrm{c} ;$ ib $1 \mathrm{~b} .45 \mathrm{c}$; lb. $80 \mathrm{c}$.

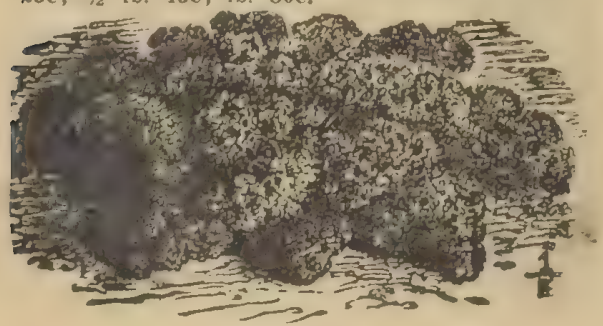

Parsle:

\section{PARSNIP} arly in spring as weather will admit, in rows 15 inches anart. When the plants are two inches high uable for the table or feeding

tong White Sugar or Hol-

low Crown. One of the

15e; $1 / 2$ lb. $22 \mathrm{e} ; 1 \mathrm{~b} .40 \mathrm{c}$.

Improved Guernsey or Cup. Shorter and thicker than the Hollow Crown: roots smooth lent flavor. Pkt. 3c; 5e. 1 it ib 15e: $22 \mathrm{c} ; 1 \mathrm{~b}, 40 \mathrm{c}$.

Maltese Half Iong. Shortcr than Irollow Crown, grite shallow $22 \mathrm{c}$; $1 \mathrm{~b}, 40 \mathrm{c}$.

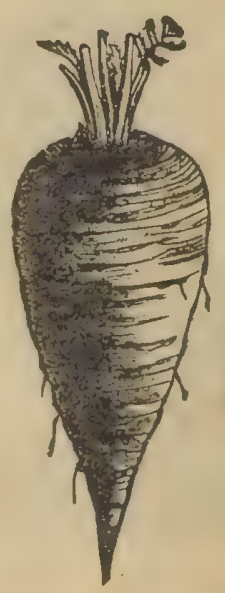

Maltese Parsnip.

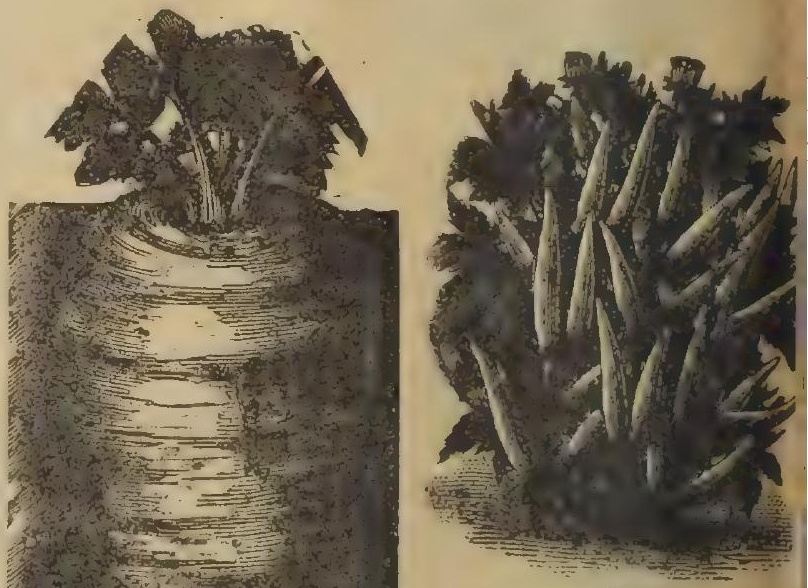

Okra.

OKRA or GUMBO straln, half-long parsnip from. many, largely grown by the $B$ and quality to any other gnet.

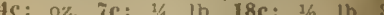
Ib. $50 \mathrm{e}$. 


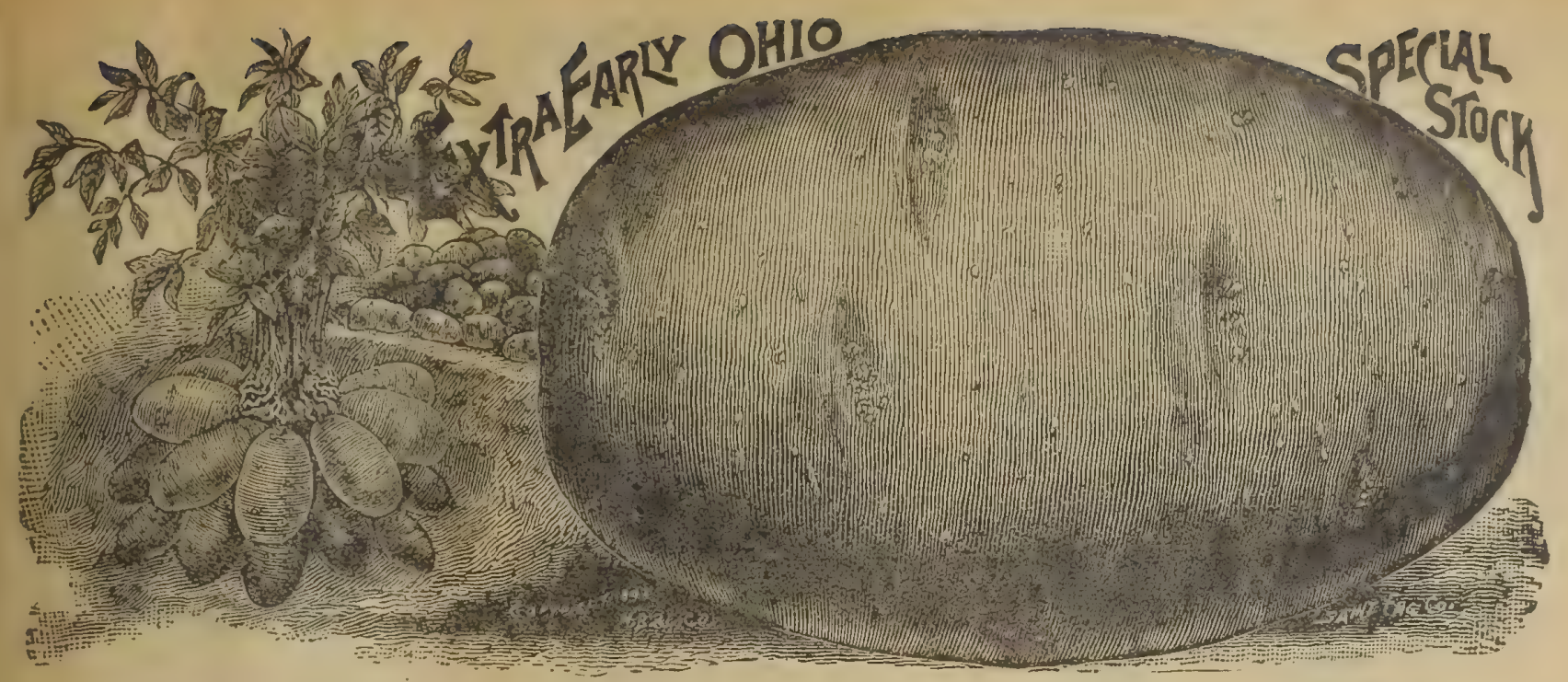

\section{SELECTED SEED POTATOES}

Potatoes by Mail. Any of the following varieties sent by mail postpaid, at $25 \mathrm{e}$ per $1 \mathrm{~b}$, three pounds 60c,

carefully labeled and packed.
Early Six Weeks Market. Grows medium to large size, resembles Early Ohio. Is very early. The tops and tubers grow so rapidly that in six weeks from planting the potatocs are fine marketable size, and reach maturity in 72 days. A fine table potato, not excelled by any other sort, oblong to round in shape, calored ylelders: $2 / 4$ bu. 50e: bu. $\$ 1.60$ : barrel $\$ 3.90$.

Early Ohio. A widely known and popular sort; is very early and has the advantage of being fit for use and sale even before fully ripe. All our potatoes are grown in the extreme north and are free from gcab. $1 / 4$ bu. 50c; bu. $\$ 1.50$; barrel, $\$ 3.80$.

Acme. Claimed to be the earliest potato grown. It can be marketed ten days before the top dies. Hills of new potatoes of fit size for table use can be dug in five weeks from tlme of planting, and top thoroughly ripened in $S$ or 9 weeks with crop fully matured. The tubers are flesh-colored and oblong in shape, of fine quality and extra large yielder. $1 / 4$ bu. 50e; bu. $\$ 1.50$; barrel $\$ 3.80$.

Irish Cobbler A World Wide Favorite. It is a most excellent extra early variety, maturing good slze tubers seven weeks from time of planting. It has also the remarkabl characteristic of producing very few, if any small potatoes, all the tubers being of marketable size The vines make short, upright growth, so that the hills may be wily a short distance apart. The flesh is pure white, with a clean, smooth, Splendid keep rs. and a first-cliss sort. $3 / 1 /$ bu, 50c; bu. $\$ 1.60$; barrel $\$ 3.90$.
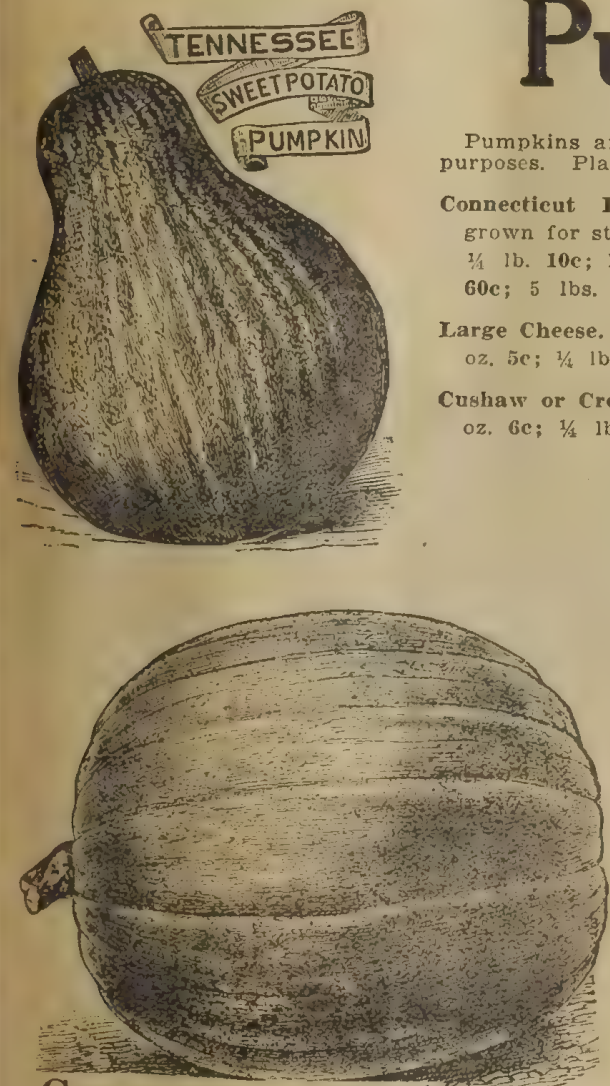

Connecticut Field.

\section{Pumpkins}

Pumpkins are principally cultivated for a gricultura purposes. Plant seeds in May in hills 8 feet apart.

Connecticut Field. Large yellow, very productive, grown for stock, very good for pies. Pkt, 2c; oz, 5c Ib. 10c; 1b. 30c. By express, not prepaid, 3 lbs. $60 \mathrm{c} ; 5$ lbs. $90 \mathrm{c}$.

Large Cheese. The best variety for cooking. Pkt. $3 \mathrm{c}$; $02.5 \mathrm{c} ; 1 / 2 \mathrm{lb}, 18 \mathrm{c} ; 2 / 2 \mathrm{lb}, 30 \mathrm{c} ; 1 \mathrm{~b}, 50 \mathrm{c}$

Cushaw or Cream, A rich and popular sort pkt, 3 : oz. $6 \mathrm{c} ; 1 / 1 \mathrm{lb} .18 \mathrm{c} ; 1 / 2 \mathrm{lb} .30 \mathrm{c} ; 1 \mathrm{~b}, 50 \mathrm{c}$.

King of the Mammoths.

weights. The heaviest grown since its introduction was 245 lus. Skin of light salgrain: excellent quality: splendid for pics and table use, hea
oz. 10c; $1 / 4$ lb. $30 \mathrm{c}$.

Large Tours or Mammoth. Is of immense size, often weighing 150 lbs. Pkt, 5e; oz. 10c Small Sugar. Very prolific: 8 inches in diamwell. Pkt, 3c; oz 6c; $1 / 4$ ib, 18c; $1 / 2$ ib. 30e: Tennessee Sweet Potato Pumplin. Excellent creamy white, finc grained; sweet and deJapanese Pie. keepers, and weigh is to 20 pounds cach The flesh is a rich salmon color, unusually
fine grained. For making pics, custards. 4c; $0 z$ the certainly have no equal. Per p

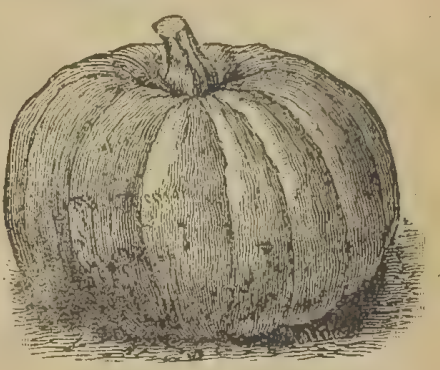

SMALL SUGAR PUMPKIN.
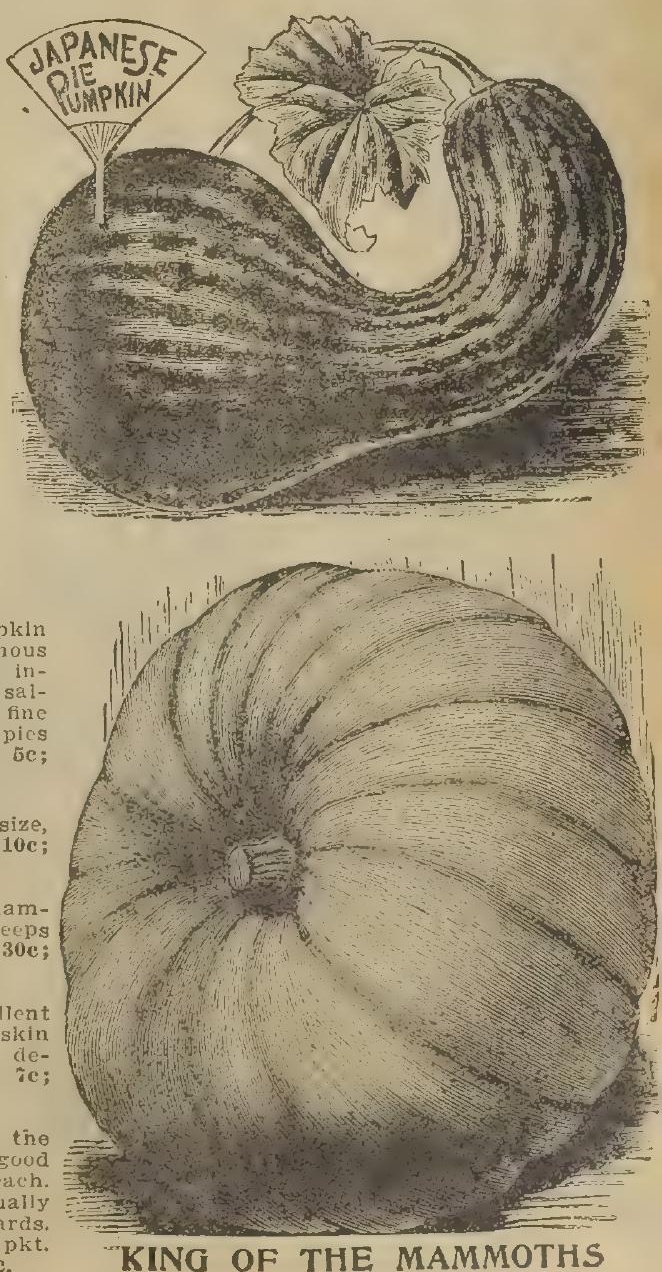

KING OF THE MAMMOTHS 


\section{(HINESE}
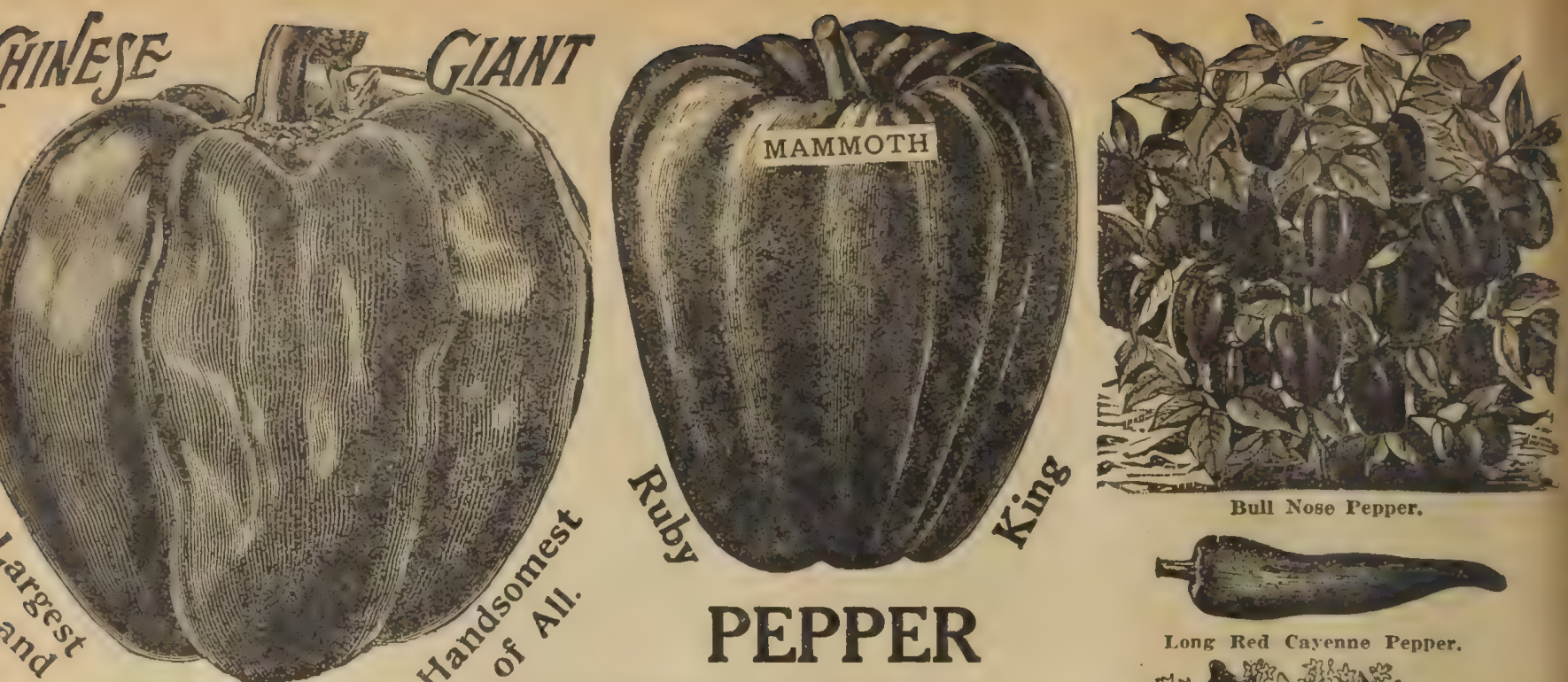

PEPPER

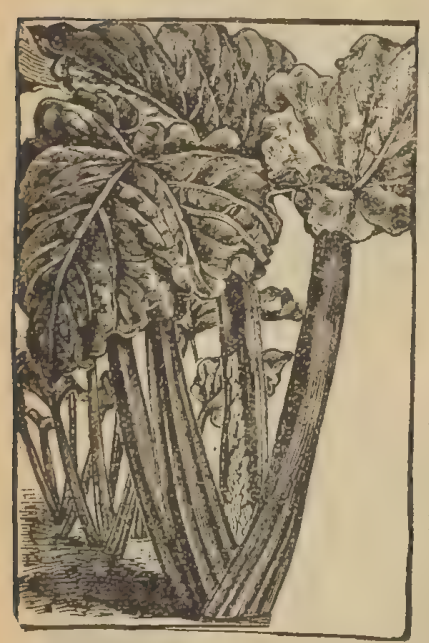

RHUBARB, or Pie Plant.

Ib. $25 \mathrm{c}, 1 / 2$ lb. $45 \mathrm{c}, 1 \mathrm{~b} .75 \mathrm{c}$.
victoria. Is very large. Later
Sow seed early in April in hotbed, and transplant to

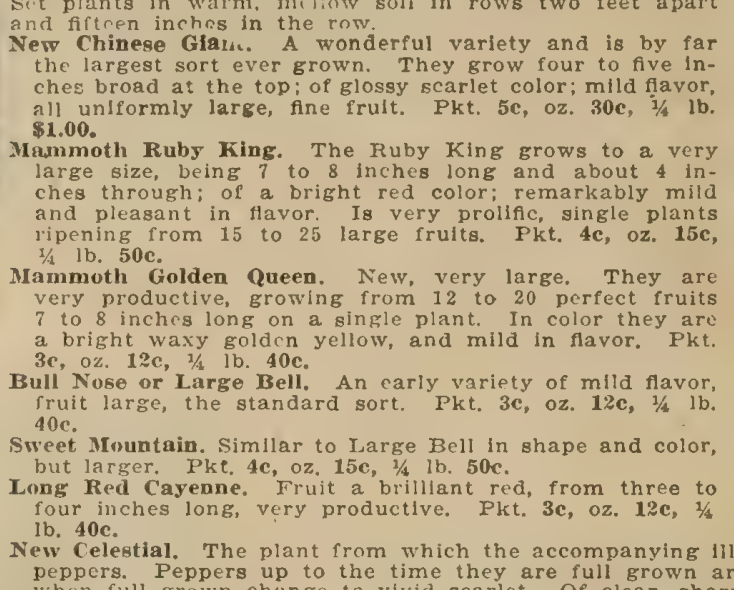

\section{PEAS}

Carter's Daisy or Dwarf Telephone. This splendid varicty of medium early Peas is excellent very productive, plants frequently bearing from flve to seven pods. no tendency to sport,

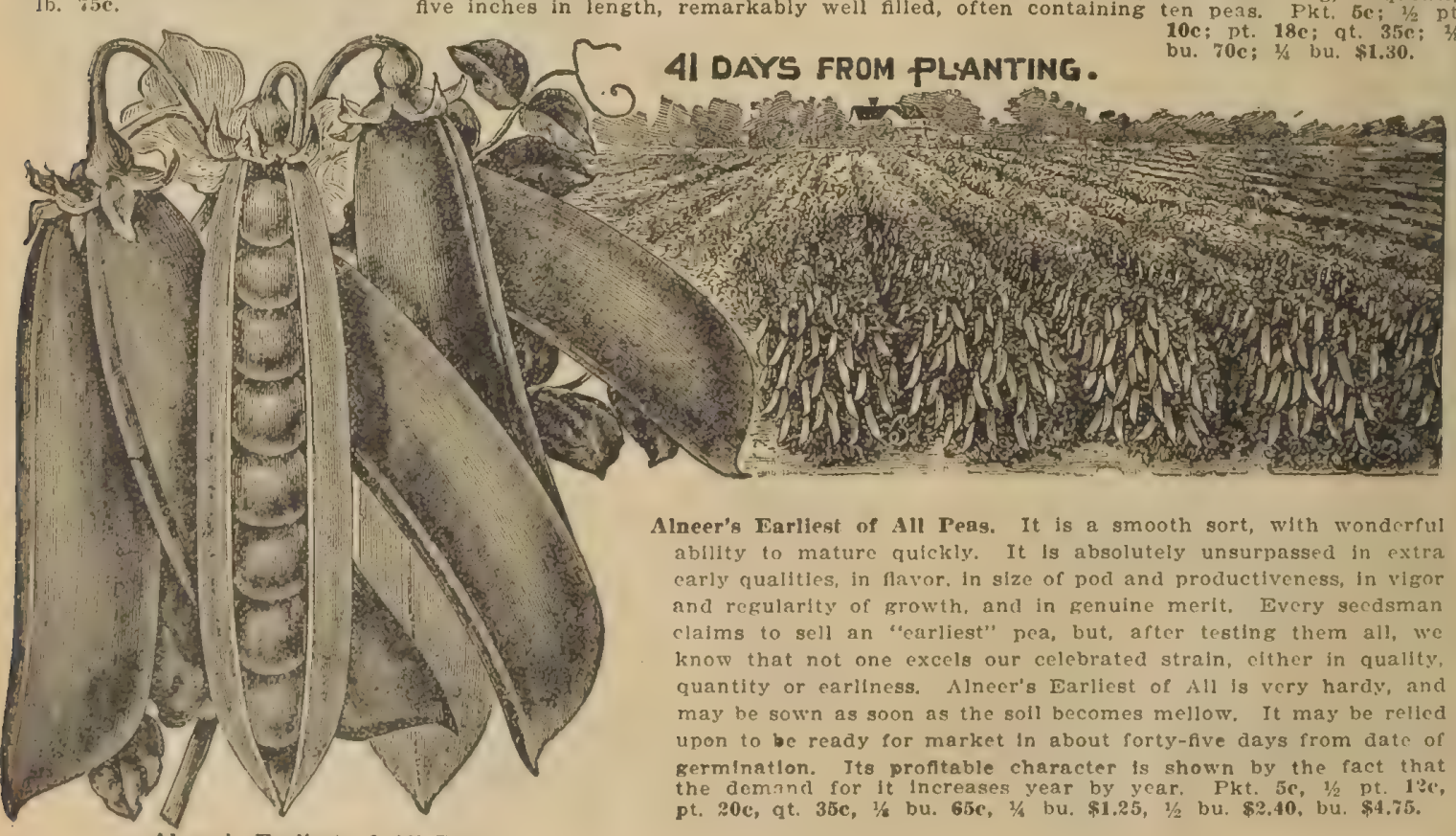

Long Red Cayenne Pepper.

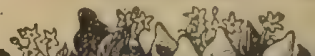

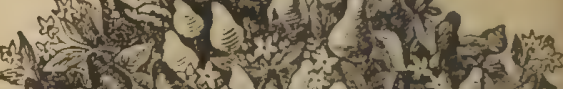

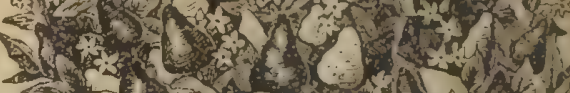

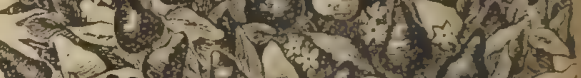

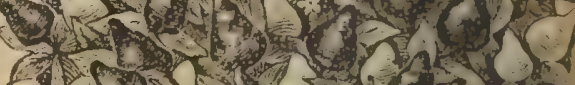

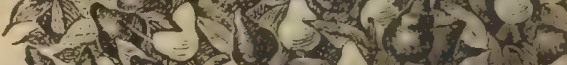
Ex

New Celestial.
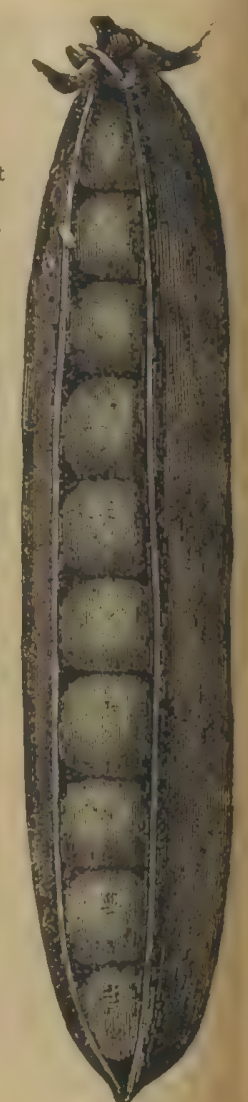

Daisy Peas, 


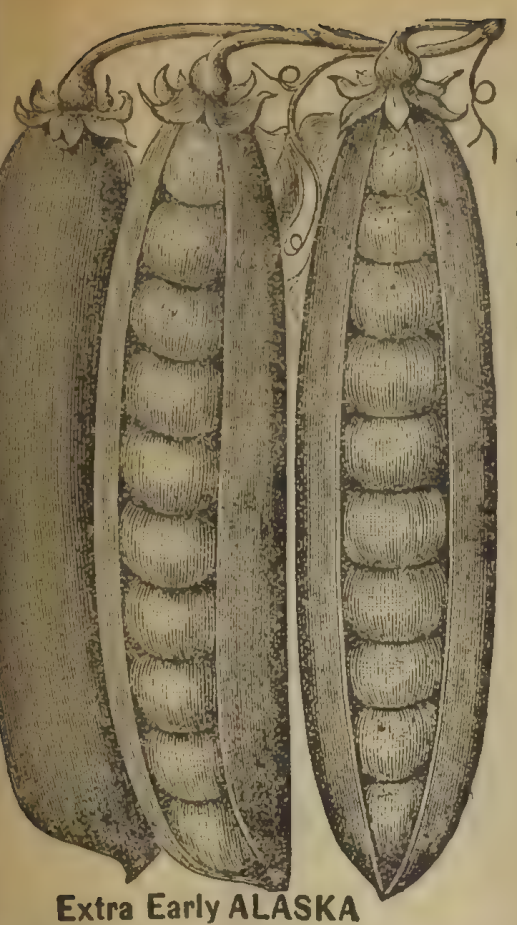

Extra Early ALASKA

utton's Excelsior. This tha Pea is so hardy that it may safely be planted as early as the hard-seeded "Extra Earines. high, exceedingly productive, and the quality is pods of any of the low-growing wrinkled Peas, but bears broader pods, and the foliage is a
lighter shade of green. Pkt. $5 \mathrm{c}$; $1 / 2$ pt. 10c; pt. 18e; qt. $35 \mathrm{c} ; 1 / 3$ bu. roc; $1 / 4$ bu. $\$ 1.30 ; 1 / 2$ bu. $\$ 2.50 ;$ bu. $\$ 4,90$.

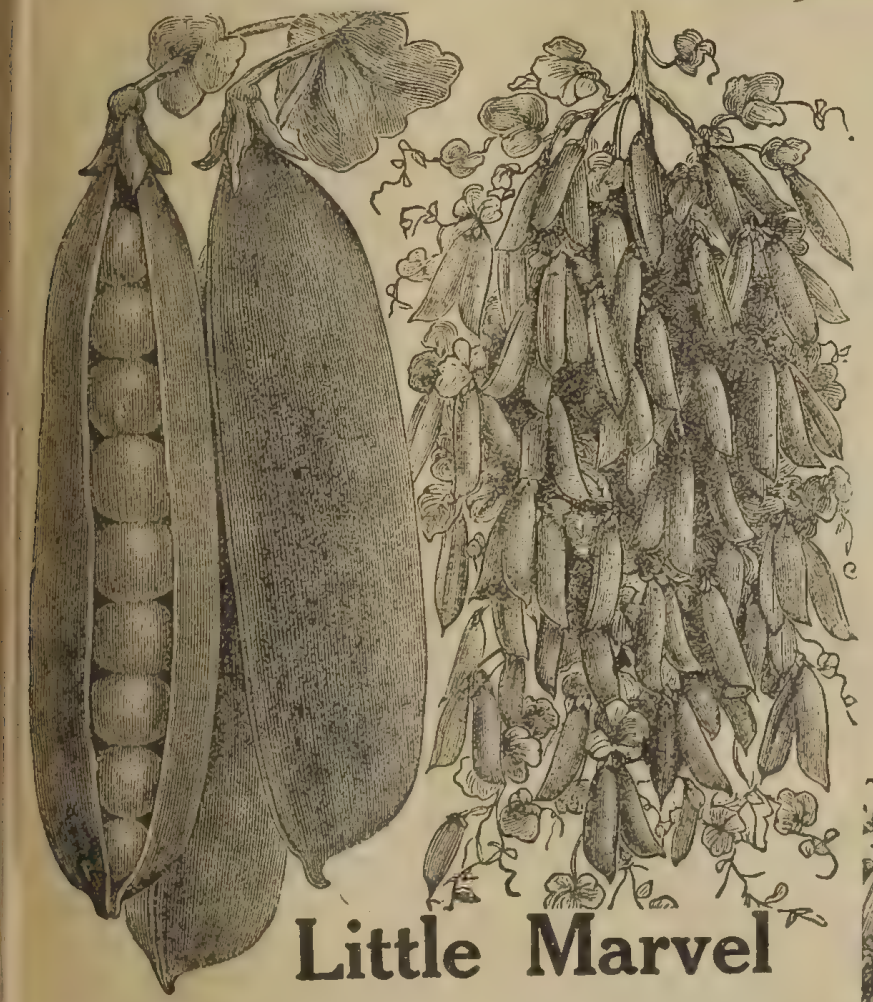

Little Marvel. A new dwarf first-early pea of unusual value, But recently on the market. The demand among marke (n) largenty borne in pilis. The pods contain from 6 to week later than most other varieties. This variety is as much larger pod. Pkt. 5e. A pt. 12c: pt. 20e; qt. 350 ; $1 / 3$ bu $85 \mathrm{c} ; 1 / 4$ bu. $\$ 1.60 ; 1 / 2$ bu, $\$ 3.10 ;$ bu. $\$ 6.00$.

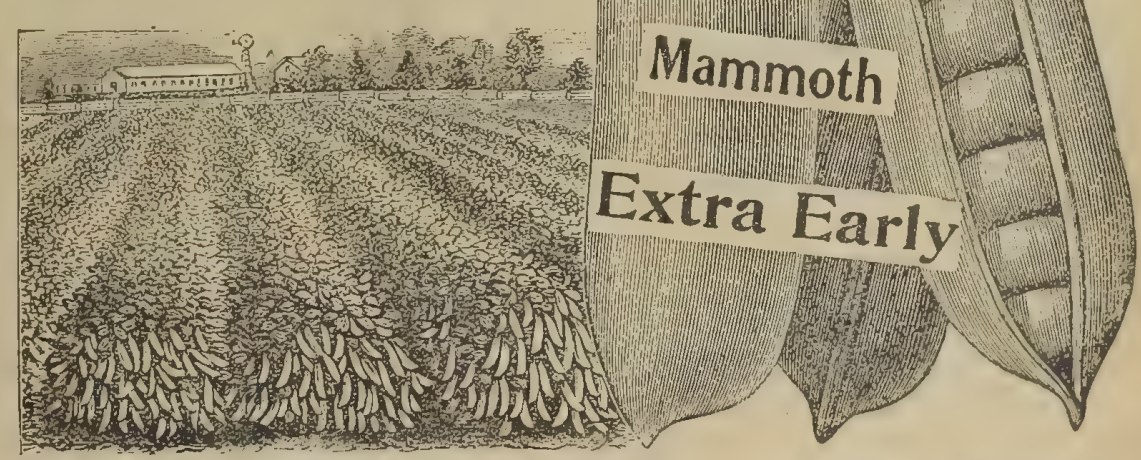

Tom Thumb. Very dwarf and
early; fine quality. Plkt. 5c;
$1 / 2$ pt. 12c; pt. 20c; qt. 35c; $1 / 8$ bu. roc; $1 / 3$ bu. $\$ 1.35$.

McLean's Little Gem. A äware

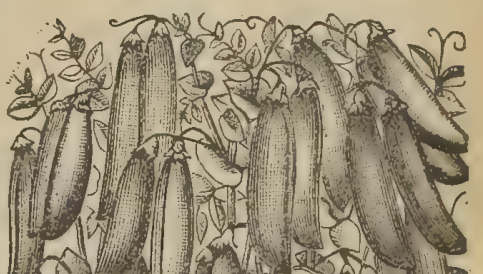

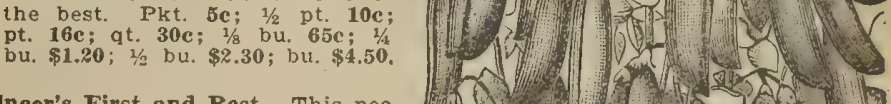

Alneer's First and Best. This pea is unsurpassed in extra earliness; a heavy ylelder. Pods good-sized and well filled; of inches to two feet. It is a splendid pea for market gardeners Large pkt. 5c; 1/2 pt. 10c; pt.

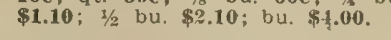
Blisa American Wonder. One of best of the wrinkled sorts. In ity, they are unsurpassed. They growing from 10 to 14 inches high. Pkt. 5c; $1 / 2$ pt. 12c; pt. $\$ 1.20 ; 1 / 2$ bu. $\$ 2.30$; bu. $\$ 4.50$.

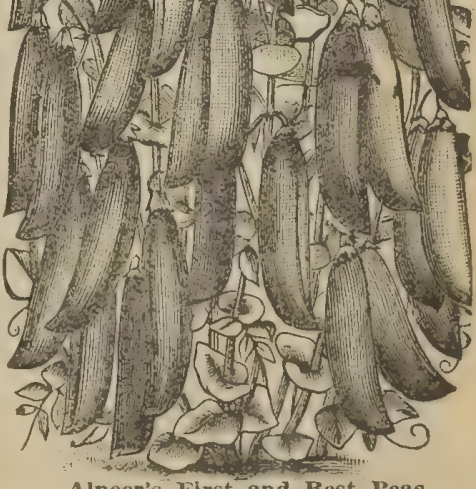

Alneer's Flrst and Best Peas.

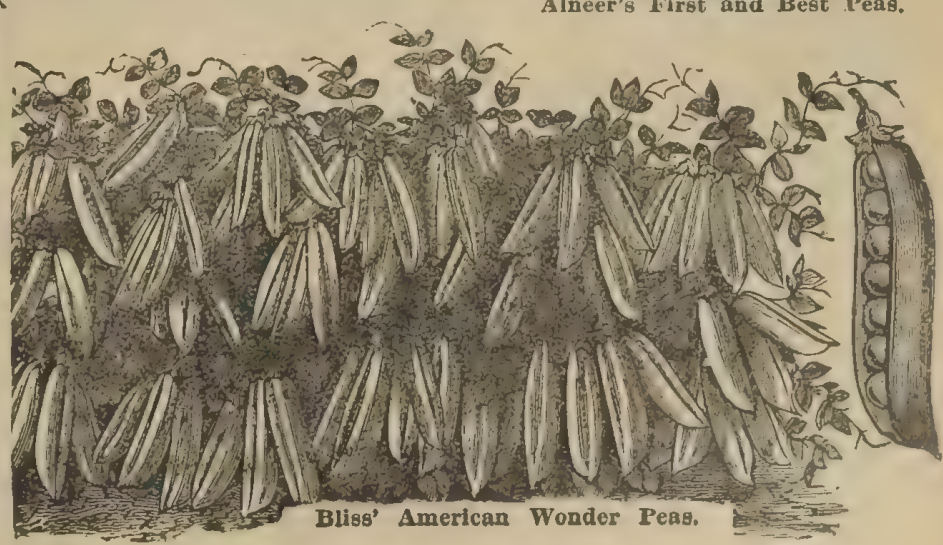




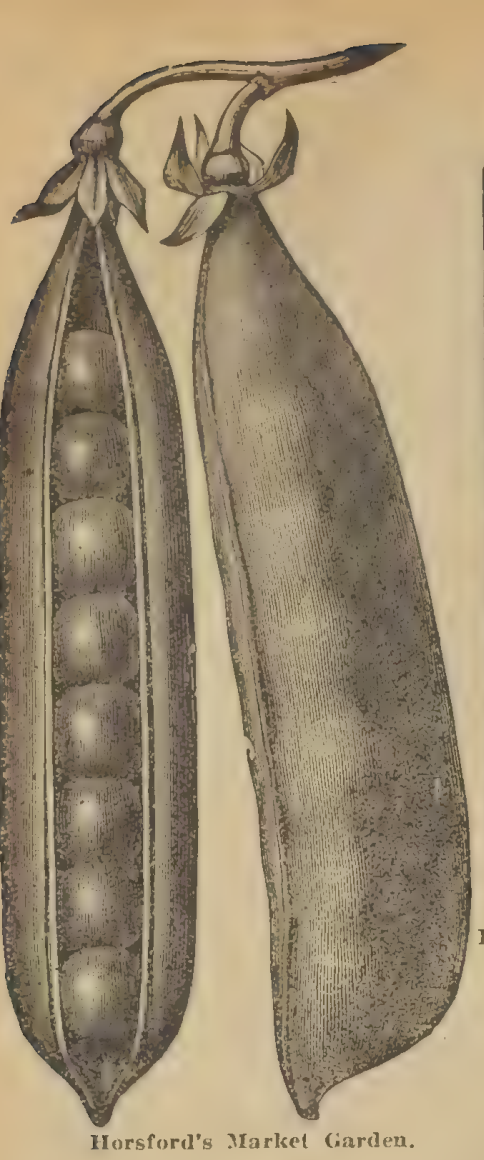

mincmarere

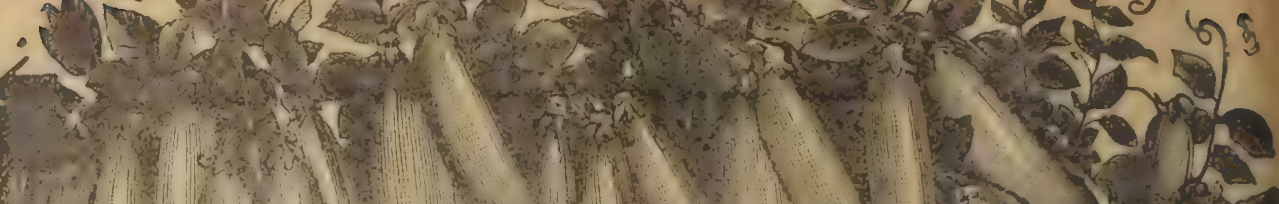

Horfford's Market Garden. A grand wrinkled variety, com-

high; is very stocky and requires no brushing. It is
extremely prolific, and always bears its pods in pairs. A

good market pea. Pkt. 5c: $1 / 2$ pt. 10e; pt. 16,

McLean's Adrancer. An excellent second early, wrinkled

$1 / 4$ bu. $\$ 1.10 ; 1 / 2$ bu. $\$ 2.10$.

Champion of England. One of the best late sorts. Pkt. $5 c$; $1 / 2$ pt. 10r: pt. $16 r:$

Telephone. Large, wrinkled sort: second early, an excellent pea. Pkt. $5 \mathrm{w}^{2} ; 1 / 2$ pt. 10c; pt. $160 ;$
bu. $\$ 1.20 ; 1 / 2$ bu. $\$ 2.30 ;$ bu. $\$ 4.50$.

Nott's Excelsior. This is an parly dwarf wrinkled pea, usually round sorts. It grows about derfully productive. The even, regular habit of the plant Pkt. 5e; $1 / 2$ pt. $120 ;$ pt. $20 e$;
$\$ 1.20 ; 1 / 2$ bu. $\$ 2.20 ;$ bu. $\$ 4.50$.
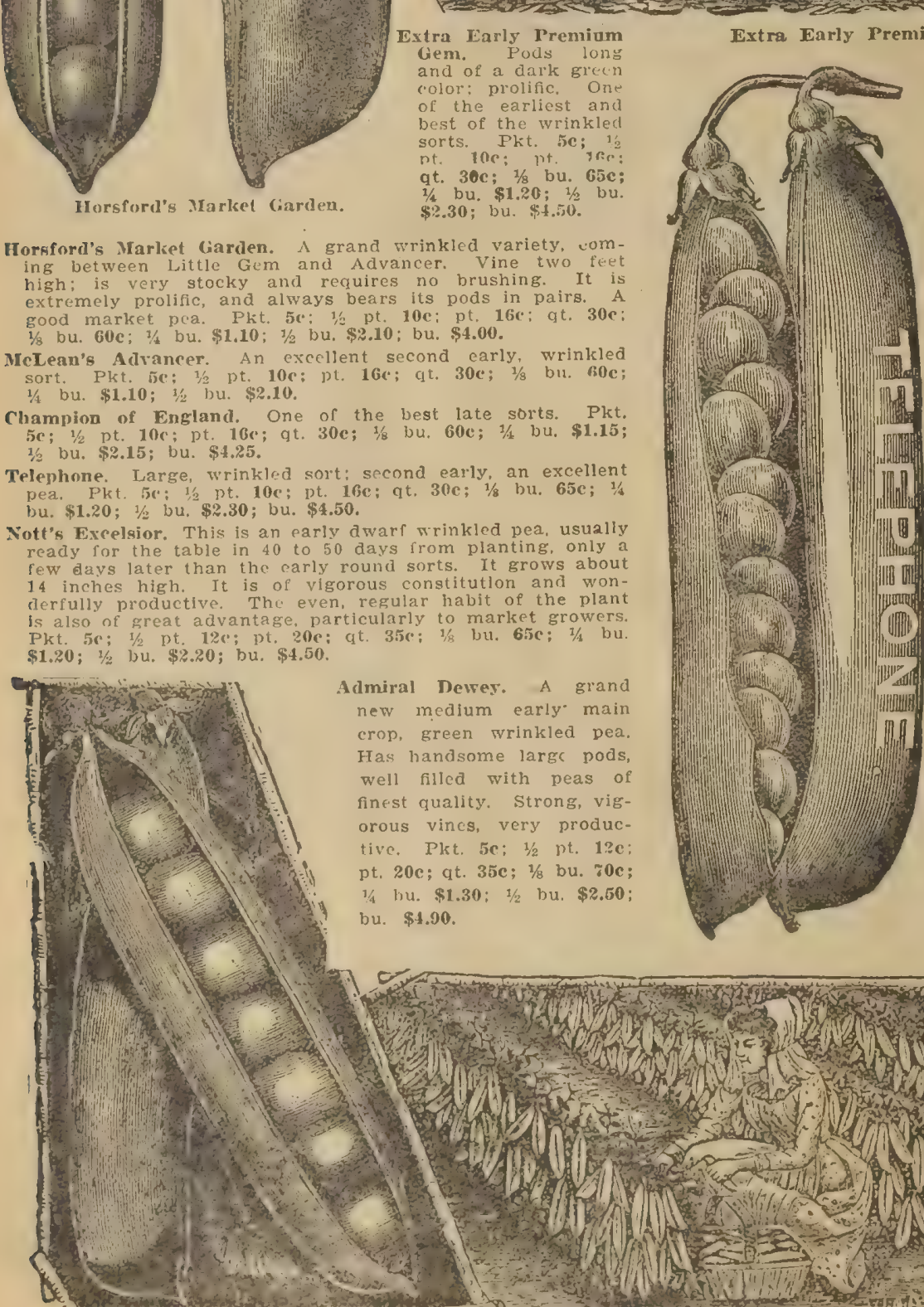

um Gem Peas.

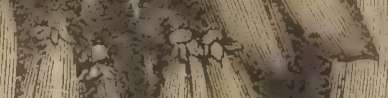

(1) 1111

(1)

L W

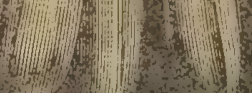

. 1 

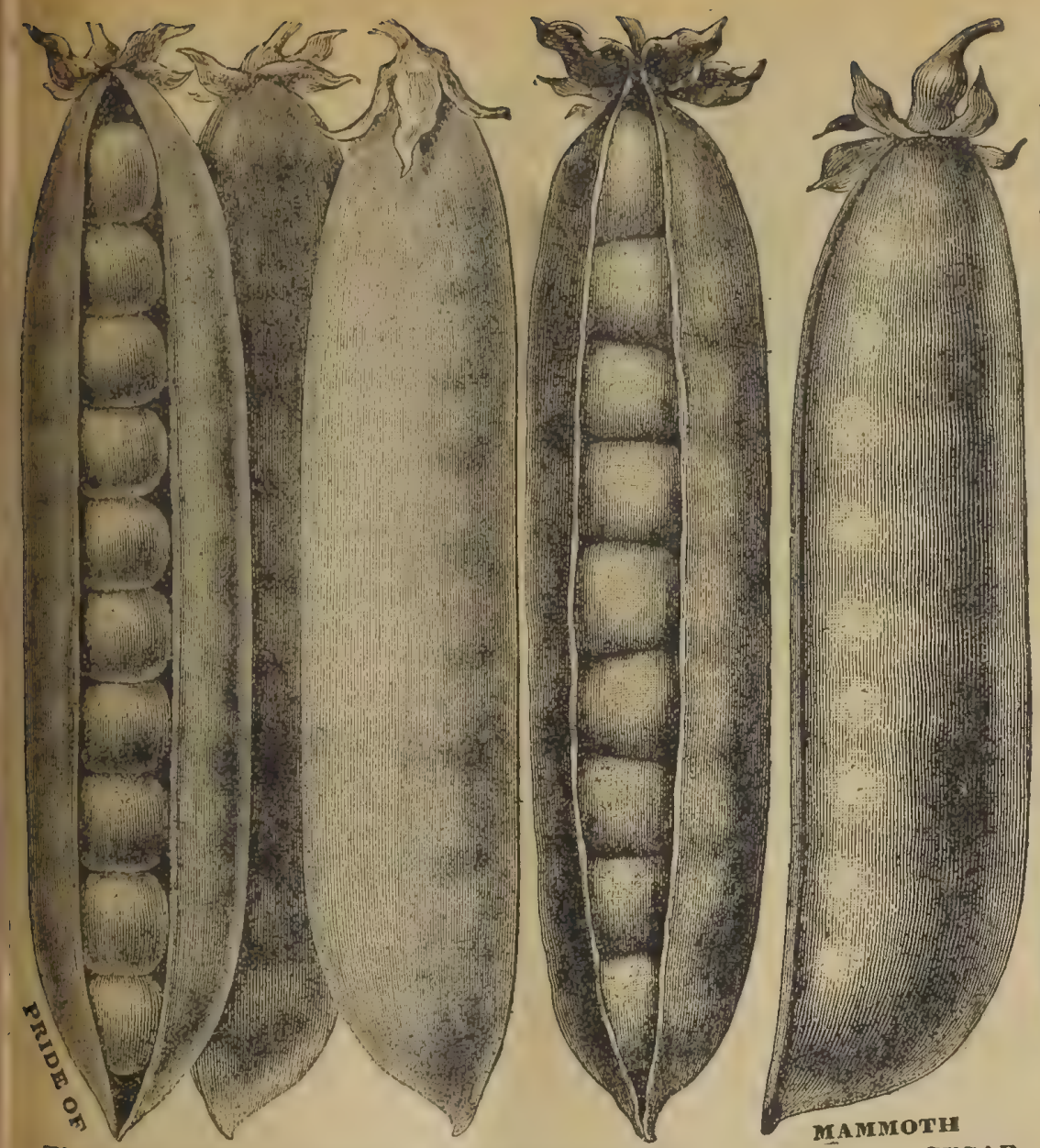

THE MARKET IMPROVED STRATAGEM. HEROINE.

MELTING SUGAR.

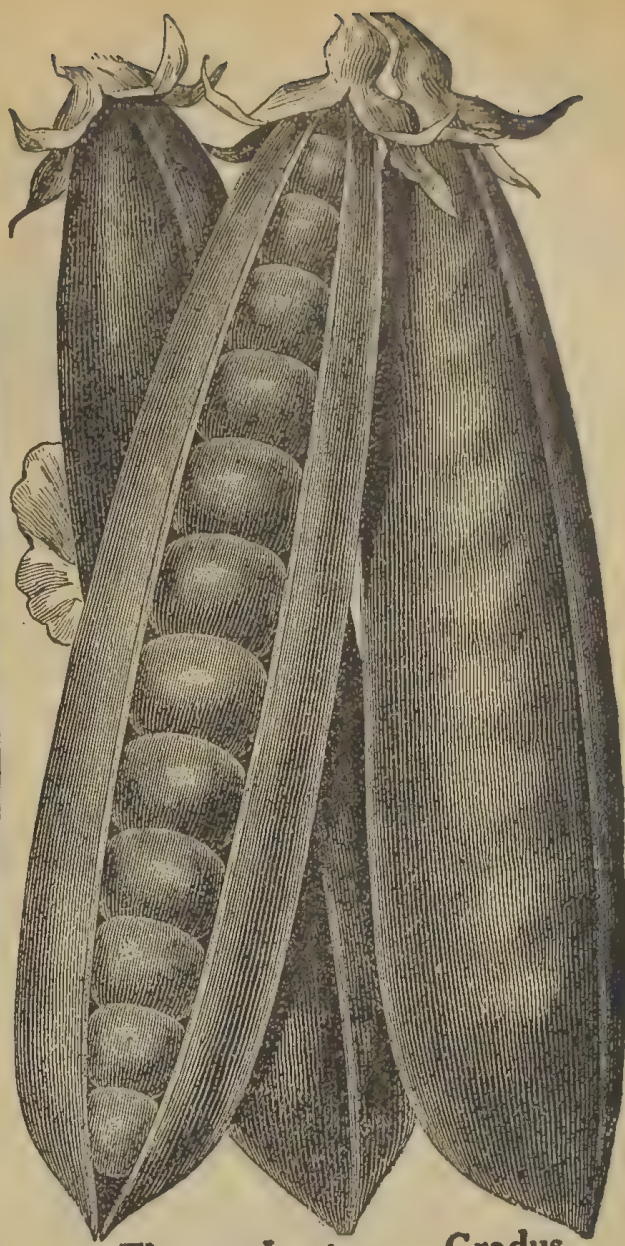

Thomas Laxton Gradus

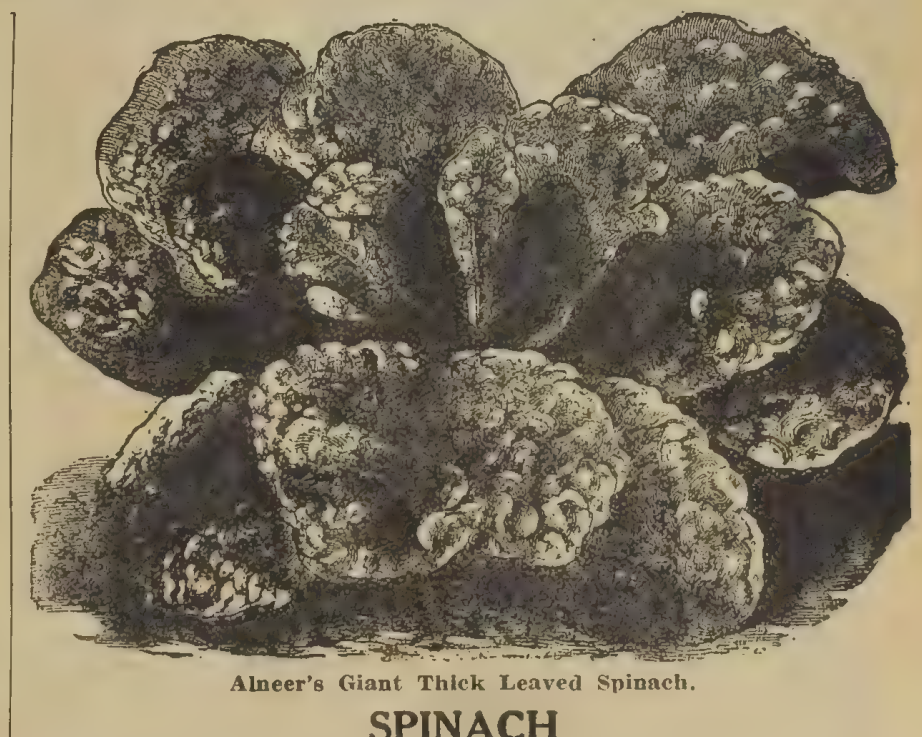

green pods of finest qualfty. Pkt. $5 \mathrm{c}$; $36 \mathrm{pt} 12 \mathrm{c}$; pt. 20c: qt, $35 \mathrm{c}$ bu, 70c: 1/4 bu, \$1.35; 1/2 bu \$2.60; bu, \$5.00.

Gradus or Prosperity Pea. A new early and hardy wrinkled varlety; is a vigorous grower; light green color. Pods large, producthe beautiful t/a pt. 12c: pt. 20c; at. 35e; $1 / 3$ bu, r0e: $1 / 4$ bu. $\$ 1.30 ; 1 / 2$ bu. $\$ 2.50$ bu. $\$ 4.90$.

mproved Stratagem. One of the very best of the wrinkled sorts. Pkt sc; $1 / 2$ pt. $10 c$; pt. $16 c$; qt. $30 c ; 1 / 2$ bu. $70 c ; 1 / 4$ bu. $\$ 1.30 ; 1 / 2$ bu. $\$ 2.50$ bu. $\$ 4,90$

leroine. Is a medium early, green wrinkled pea, and grows uniformly two to two and a half feet high. It bears a profusion of ten pt. 10c; pt. 16e; qt. 30c; $1 / 8$ bu. 65r; $1 / 4$ bu. $\$ 1.20 ; 1 / 2$ bu. $\$ 2.30 ;$ bu

ammoth Melting Sugar. This new variety is ahead of all other gar Peas in the size of pod and prollf bearins also for its delicious flavor. It grows to the height of $3 \frac{1}{2}$ feet; bears a profusion of very generally found in patrs and so brittle that they pos. Which are Swet and pat, 5c: $1 \%$ pt. $12 \mathrm{c} ; \mathrm{pt}, 20 \mathrm{c} ; \mathrm{qt}, 38 \mathrm{c} ; 1 / 8$ bu. $80 ; 1 / 4$ bu. $\$ 1.50$.

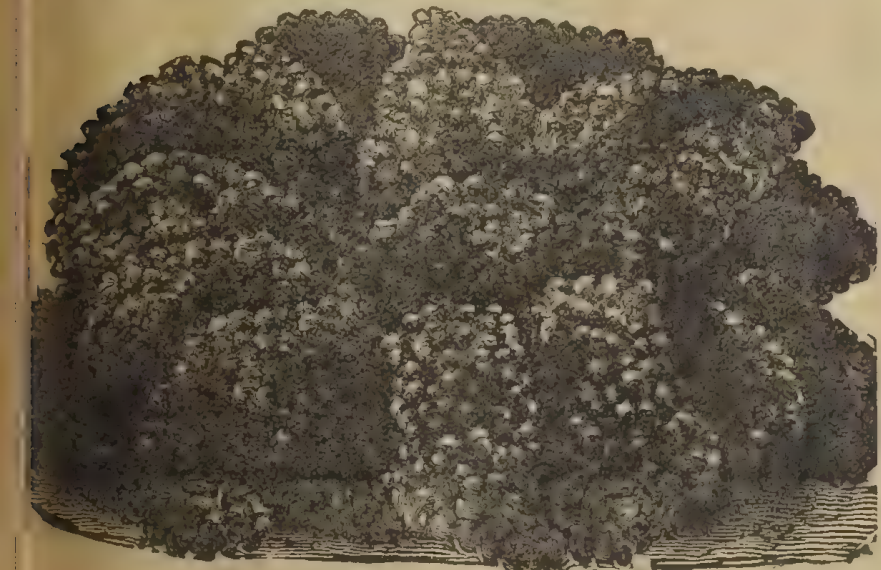



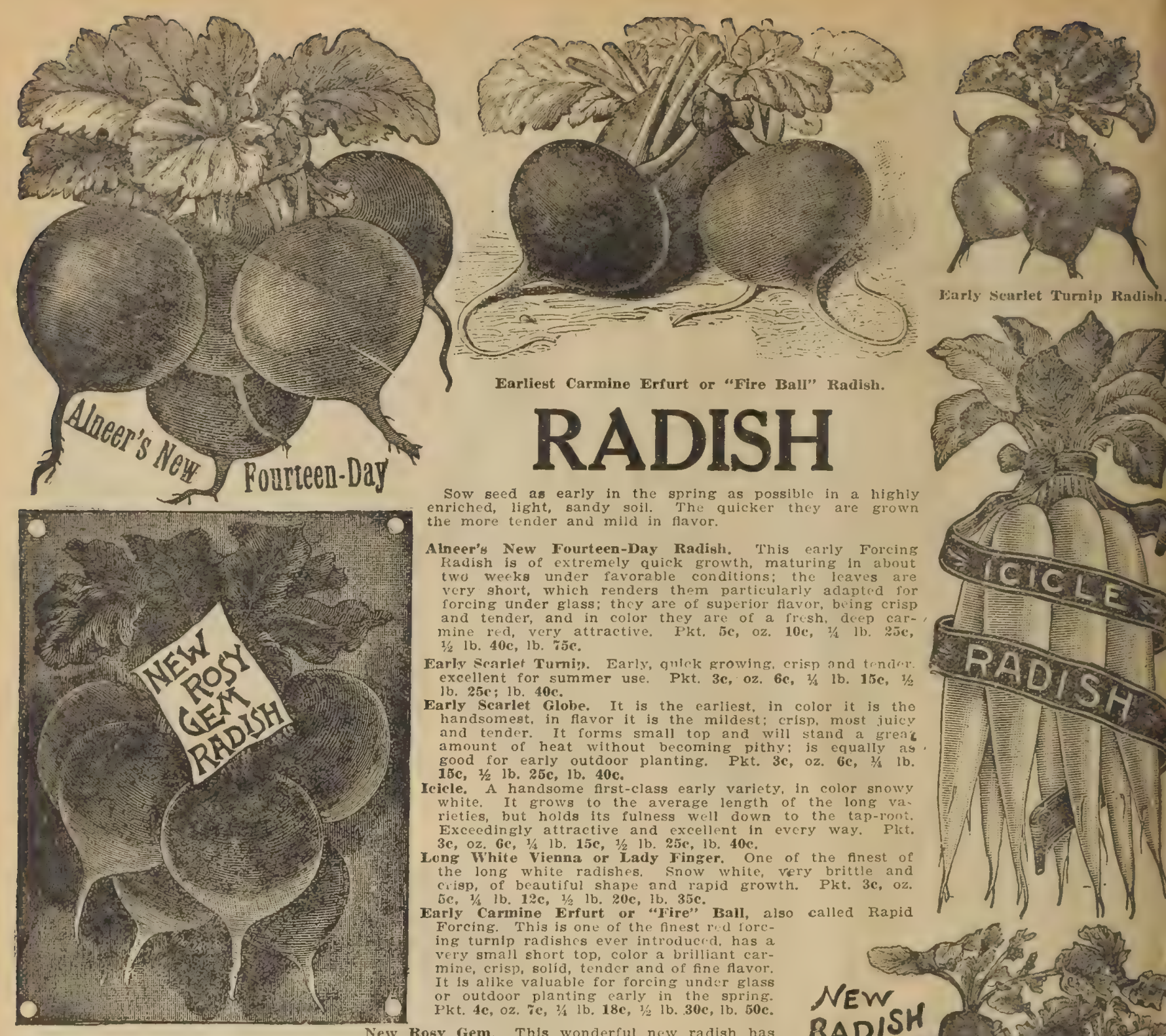

Sow seed as early in the spring as possible in a highiy Alneer's New Fourteen-Day Radish. This early Forcing Radish is of extremely quick growth, maturing in about two weeks under favorable conditions; the leaves are
very short, which renders them particularly adapted for forcing under glass; thcy are of superior flavor, bing crisp mine red, vkt. 5e, oz, 10c, 1/1 lb. 2Je, Tarly $40 \mathrm{c}, 1 \mathrm{~b} .75 \mathrm{c}$.

. ib. $25 \mathrm{c}$; $1 \mathrm{~b}$. $40 \mathrm{c}$.

Early Scarlet Globe. It is the earliest, in color it is the handsomest, in flavor it is the mildest; crisp, most iuicy amount of heat without becoming pithy: is equally as good for early outdoor planting. Pkt. 3c, oz. 6c, $1 / 3$ lb. 15c, $1 / 21 b .25 c, 1 b, 40 c$

Icicle. A handsome first-class early variety, in color snow. rieties, but holds its fulness well down to the tap-ront $3 \mathrm{c}$, oz. 6e, $1 / 4 \mathrm{lb}, 15 \mathrm{c}, 1 / 2 \mathrm{lb}$. 25e, lb. 40c. Long White Vienna or Lady Finger. One of the finest of cisp, of beautiful shape and rapid growth. Pkt, 3c, oz. Early Carmine Erfurt or "Fire" Ball, also called Rapid
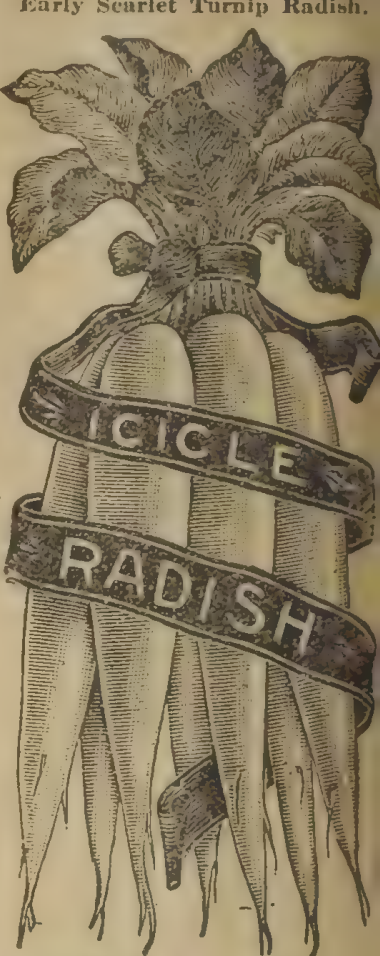
Forcing. This is one of the finest rud forcmine, crisp, sholid tep, color a brillant car or outdoe valuable for forcing under glass Pkt. 4c, oz. 7c, $2 / 4 \mathrm{lb}$. 18c, $1 / 2 \mathrm{lb} .30 \mathrm{c}, 1 \mathrm{~b}$. 50c.

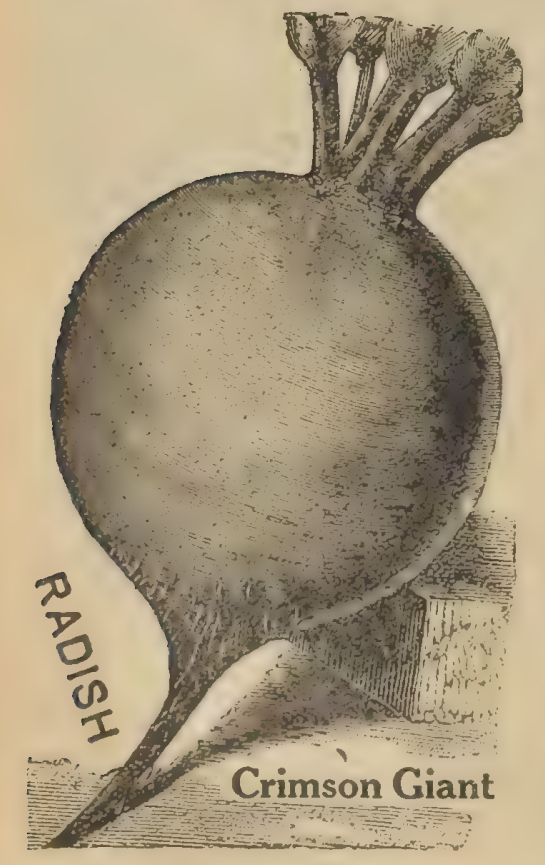
won golden opinions in all sections of the coun-

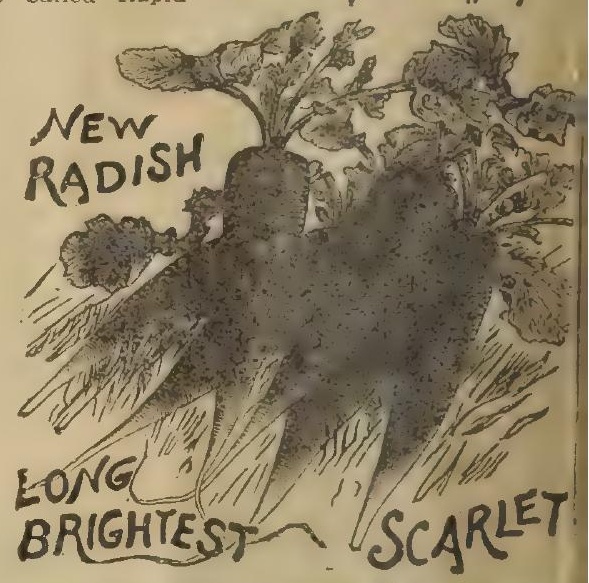

rong Searlet Short Top. The standard long va$3 \mathrm{c}, \mathrm{z}, 5 \mathrm{c}, 1 / 4 \mathrm{~b}$ market or private use. Pkt. Jong Brightest Scarlet White Tipped. The bright

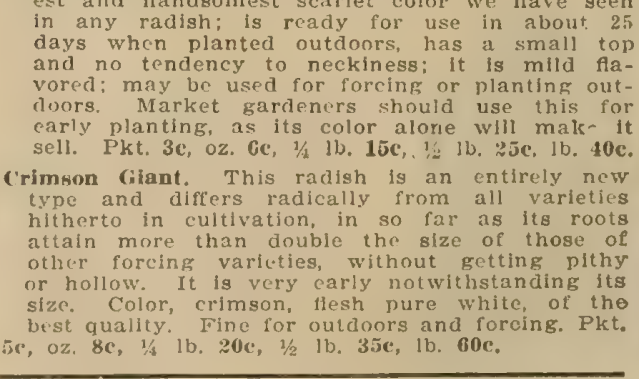

Gentlemen: Your Fourteen-Day Radish beats courtecin days. I recommend all to send to Alnecr's for high grade full of life seeds.

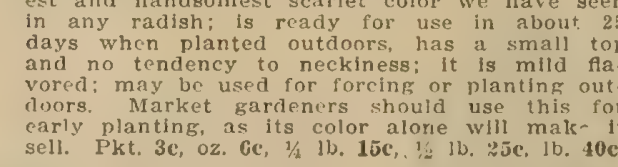
Crimson Giant. This radish is an entirely new
Pkt, 3c, oz, 6c, 1/4 lb, 15c, 1/2 lb, 25c, lb, 40c

New Model White "Box" (Also called Crrstal distinct. Phis variety is much superior and top, rapid grower, perfect turnip shape, extras the quality. and especially ht for growing under glass.
lb. $35 \mathrm{c}$.

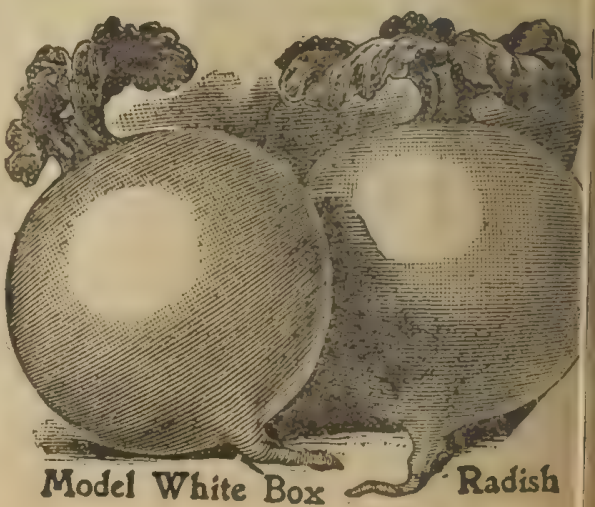




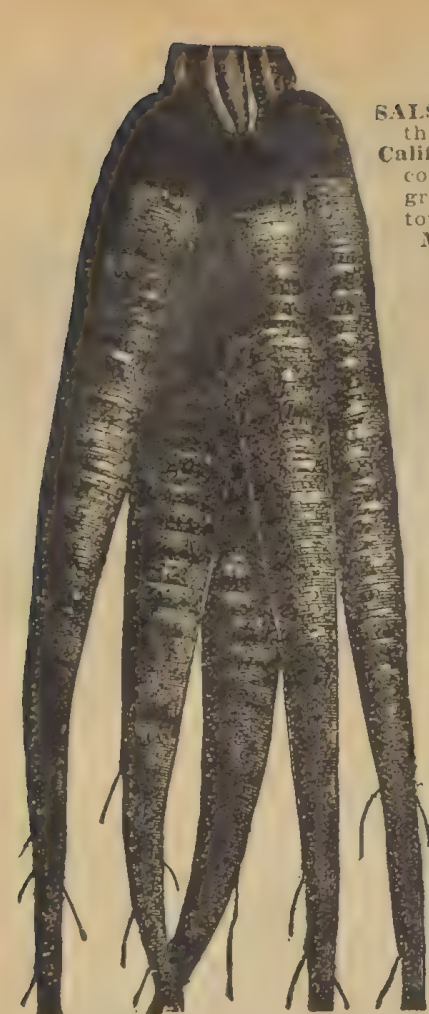

SAI.AIFY or Vegetable Osster. Sow the secd early in the spring in rich, deep soll in arllls fifteen inches ap California White Giant. This is the largest, smoothest and $m$ st proftable in cultivation. IRoots pure white color. three times larger than the ordinary salsify, of very superior quality and fine flavor, flesh very

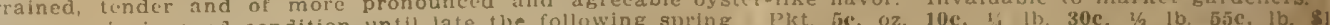

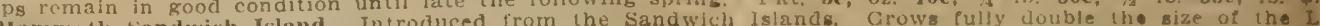

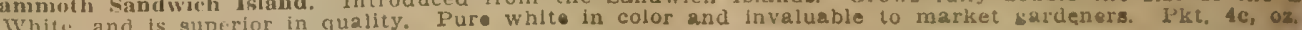

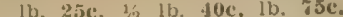

\section{SQUASH}

Plant seeds arter settled

weathor, in hills;

bush varietics two or three

ies, six to eight feet apart.

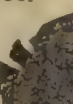

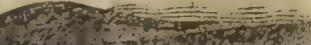

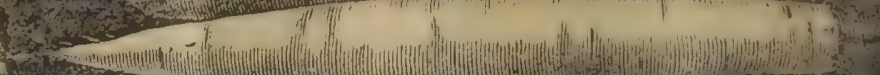

True Hubhard. A gencral favorite; is more largely Mammoth Sundwich Island Salsify. grown for winter use than any other variety; dry and excellent flavor. Our stock is true and very 1h. $50 \mathrm{c}$.

American Turban. A fine table sort; flesh orange yellow and. well flavored. Pkt. 3c, oz. 6c, 1/4 lb. 18c, $1 / 2$ lb. 30c, Ib. 50c.

Marblehead. Resembling the Hubbard but nesh lighter in color, a fine variety: good flavor. Pkt. 4c, oz 7c, $1 / 6$ lb. $20 \mathrm{c}, 1 / 2$ lb. 35e, Ib, 60e.

White Pineapple. A fall and winter variety. The skin and flesh are of a pure creamy white color. Pkt. 3c, Cal. White Giant Salsify. oz, 6c, $1 / 4$ lb. 18c, $1 / 2$ lb. $30 \mathrm{c}, 1 \mathrm{~b} .50 \mathrm{c}$.

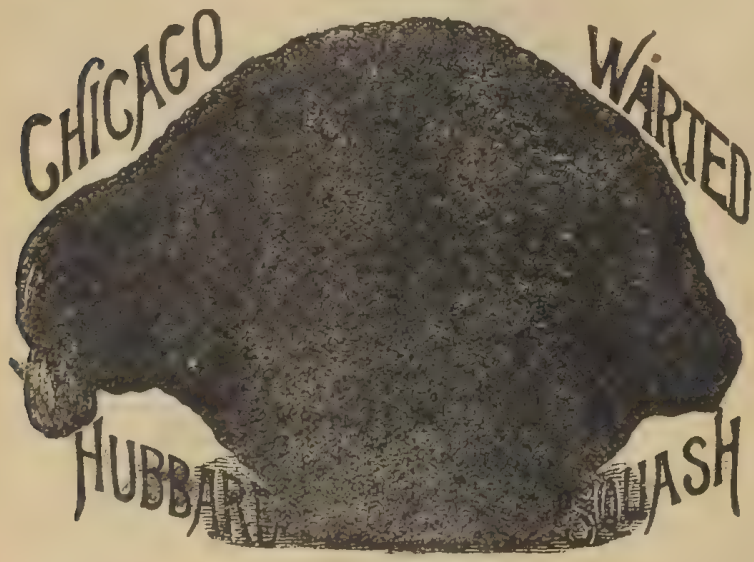

Chicago Warted IIubloard. It combines the fine points of the original strain with increased size, rougher shell, improved quality, thick llesh.
$1 / 2$ lb. 30e, $1 \mathrm{~b}$. 50c.

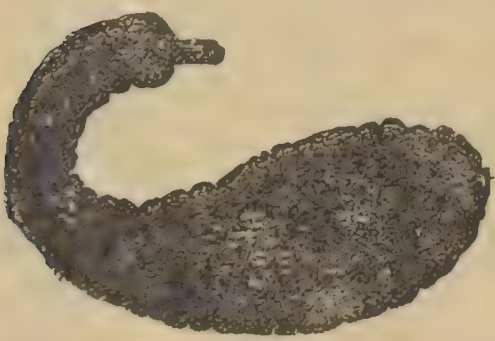

Giant Golden Summer Crook-Neck. Early and good quality, iruit of orange yel$1 / 2$ ib. $30 \mathrm{c}, 1 \mathrm{~b}, 50 \mathrm{c}$.

White Bush Scalloped, $18 \mathrm{c}, 1 / 2 \mathrm{lb} .30 \mathrm{c}, 1 \mathrm{~b}$. $50 \mathrm{c}$

Yellow Bush Scalloped. Similar to the 7c, $1 / 61 \mathrm{~b} .18 \mathrm{c}, 1 / 21 \mathrm{~b} .30 \mathrm{c}, 1 \mathrm{~b} .50 \mathrm{c}$.

Fordhook. The nesh is dry and sweet, It reeps in in June. Pkt. 3c, oz. $y_{c}, 1 / 4$ lb, 20e.
Prolife Orange Marrow. The skin is of deep

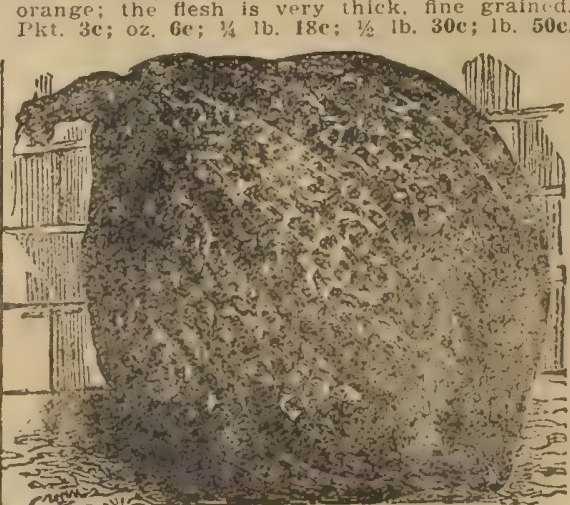

PROEWTO ORANCE MARROW BQUASU.

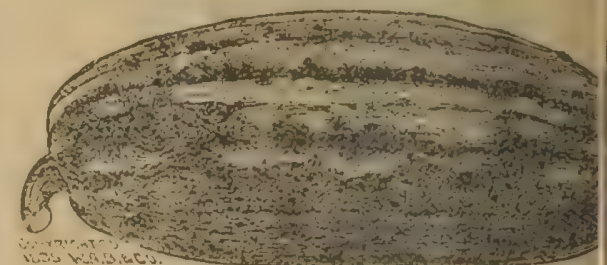

THE DELICATA SQUASM

Delicata. Early and very prollfic: of oblong Ground color nrange-yellow, splashed and B with very decp green. Although of small giz squashes are very solld and heavy, whlle the q

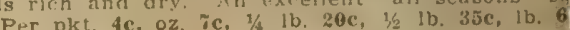
Escex Mybrid. It is a cross between the Turba Hubbard the nesh is very thick and solid, a goor keeper. $3 \mathrm{c}, 0 \mathrm{z}, 0 \mathrm{C}, 1 / \mathrm{s}$ ib. $18 \mathrm{c}, 1 / \mathrm{s} / \mathrm{b}, 30 \mathrm{c}, 1 \mathrm{~b} .60 \mathrm{c}$ 


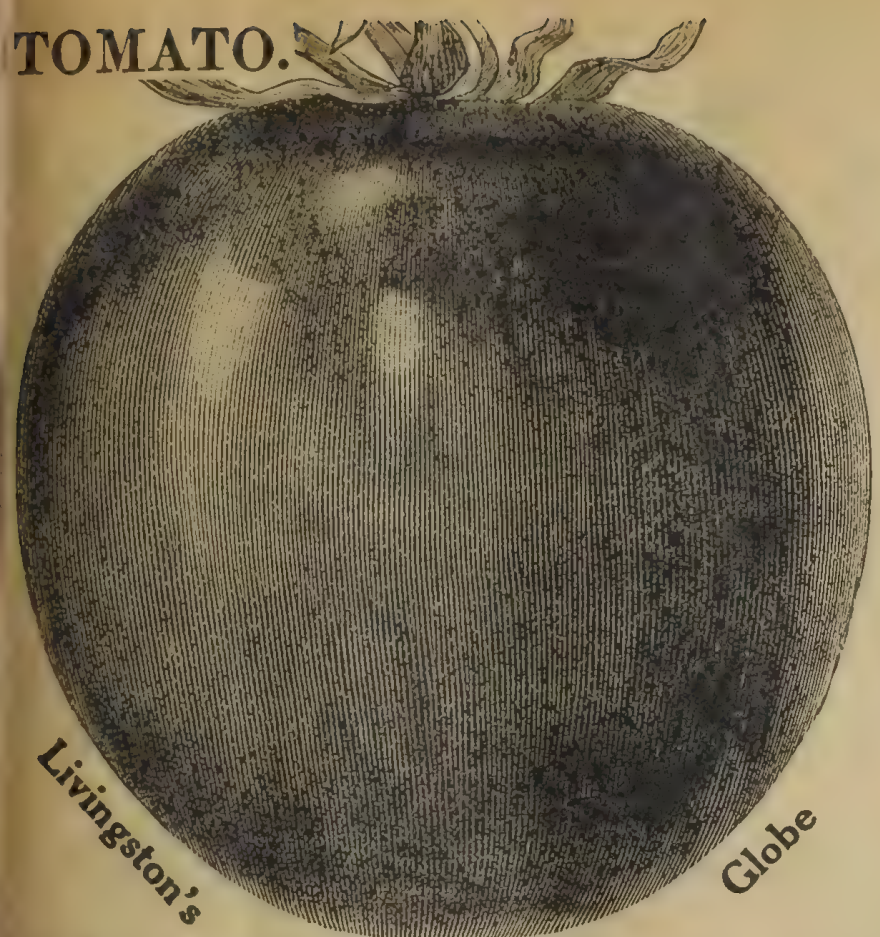

I. Avingaton's Globe. A new variety of exceptional merit. It is of beautiful globe shape, which permits of a greater number of slices beIng taken than from flat rruited sorts. Among the first to ripen, although of large slze, very smooth, firm fleshed, few seeds, ripens evenly; color a beautiful glossy
$1 / 4 \mathrm{lb}, 60 \mathrm{c}, 1 / 2 \mathrm{lb}$. $\$ 1.10,1 \mathrm{~b}, \$ 2.00$

Ponderosa, No. 400. The vines are strong and vigorous and easily carry their enormous weight of fruit. Tomatoes weighing nearly four pounds are or common occurrence. Pkt. 5c, oz. 20c, $1 / 4$ 1b. 70c.

Earliest June Pink. This is a new variety, slmilar in hablt to the famous "Earliana," differing only in its color which is pink in color instead of red. The plant is neat and compact, branching freely, with fruit hanging in clusters. Under exactly the same conditions as Earliana, the June heavy yielding, are its main characteristics. An excellent shipper on account of its reasonably tough skin. Will take a place at the $h$
the pink sorts. Pkt. $5 c, 0 z .20 \mathrm{c}, 1 / 1 / 1 \mathrm{~b}, 60 \mathrm{c}, 1 / 21 \mathrm{~b}$. $\$ 1.00,1 \mathrm{~b} . \$ 1.75$,

Crimson King. Is more symmetrical in shape than the Ponderosa and is much thlcker through from stem to blossom-end; in fact, so marked is this characteristic that it is frequently almost round. up almost completely to the stem. The Crimson IKing, like the Ponderosa is almost seedless. The fiesh is firm and meaty, solid as beetrosa, lo al of superb quallty. It is enormously prolific and early tor so large a tomato. Pkt. 5c, oz. 20c, 1// 1b. 70c, $1 / 21 \mathrm{~b}$. $\$ 1.25,1 \mathrm{~b} . \$ 2.40$.
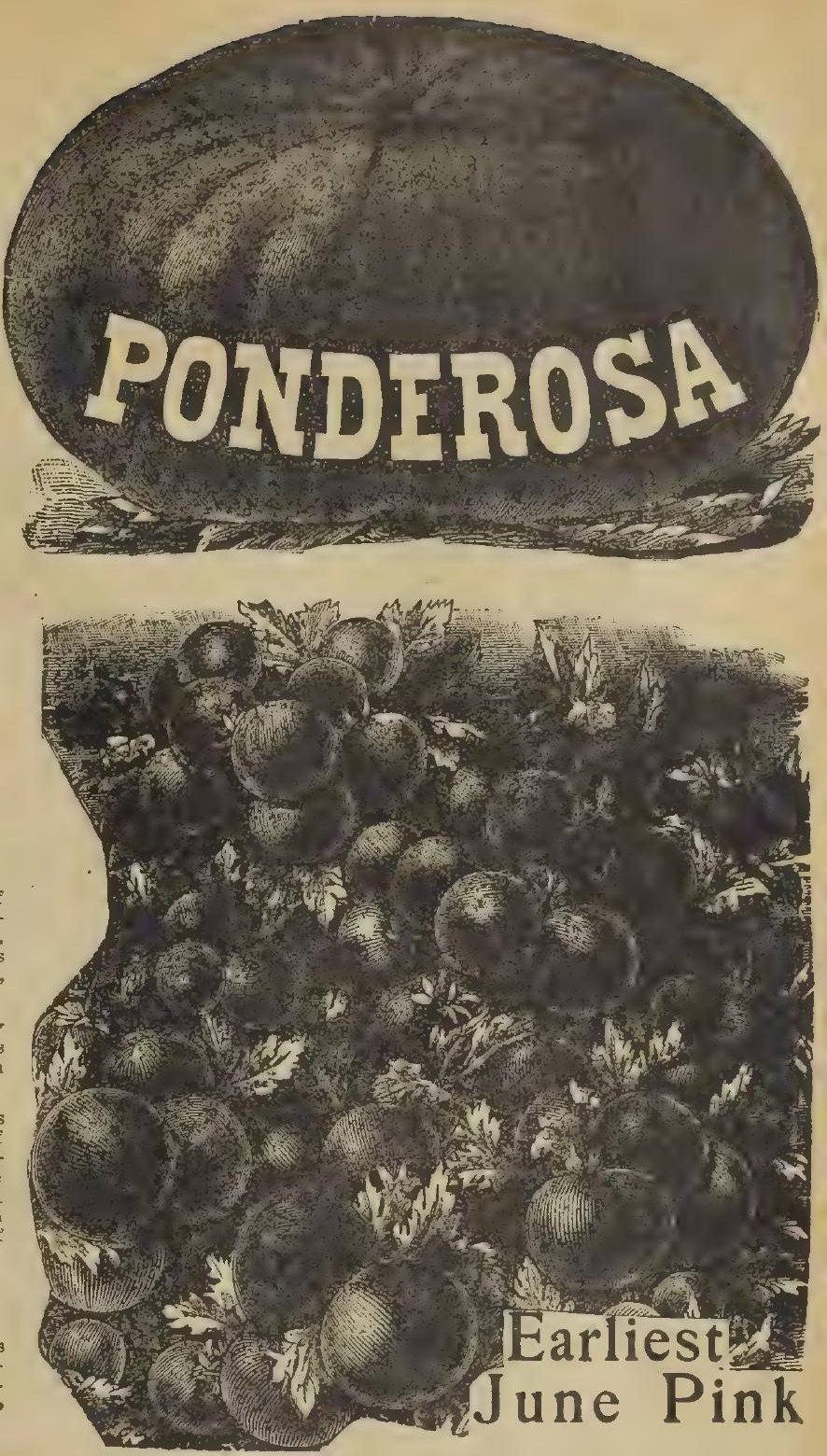

Alneer's Great Giant Tree Tomato. A new to15 feet high, trained on trellis fromit medium to large size, of meaty and luscious flavor Immense bearers, from 50 to 100 lbs. Don't Iresitate to Plant the Beat.

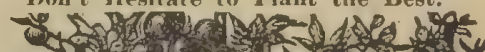

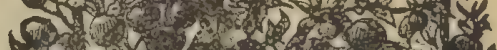

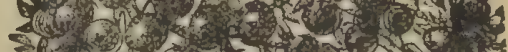
सैं

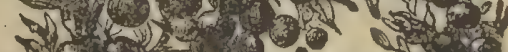

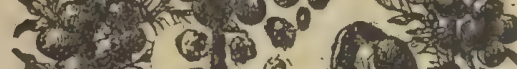
\%

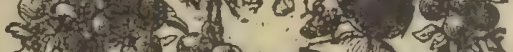

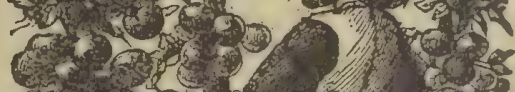

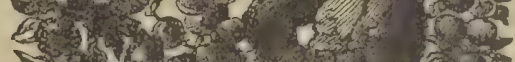

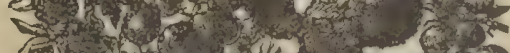
colvent

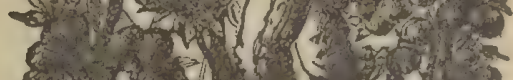
$y_{1 y}^{2} y^{2}$ Alpeer's GRATETOWATO 


\section{TOMATO}

Tomatoes do best in warm. moderately rich soll. Suw sceds early in March in hot bed or house, in ahallow boxes. About May 15 to 20 in this latitude the plants should lo set out in the open ground, in rows four feet apart each way. All serds we offer are from eritically silected specimens of

Spark's Earliana. This new tomato is claimed by the originator to be very early, of large size, for so early a sort. Handsome shape, uniform size, of a quallty. Price, pkt. 5c, oz, 18c, $1 / 4 \mathrm{lb}, 50 \mathrm{c}, 1 / 3 \mathrm{~b}, 80 \mathrm{c}, 1 \mathrm{~b}, \$ 1.50$.

Alneer's Dwarf Champion Bush. It is of pecullar growth and habit, dwarf and compact, with thick, stiff stems self-supporting, upright growth, allowing it to be planted much closer together than other varieties. It is very early; in ract, It being the carliest tomato we have ever grown. The frult is of handsome and of fine quality and very productive. Pkt. 5c, 0z. 15c, 1/4 lo. $50 \mathrm{c}, 1 / 2 \mathrm{Lb}, 80 \mathrm{c}, 1 \mathrm{~b}, \$ 1.50$.

Chalk's Early Jewel. The large, handsome fruits are very solid and decp through, befing aimost round. very early and productive: the plants are flavor. Pkt. be, oz. 18c, $1 / 4 \mathrm{lb}, 50 \mathrm{c}, 1 / 2 \mathrm{lb}, 80 \mathrm{c}, 1 \mathrm{~b}, \$ 1.50$.

Iivingston's Beauty. The color is quite distinct, being a very dark crimson, shading in purple, the color alone bringing it Into favor. It grows in clusters chipping lb. $40 \mathrm{c}, 1 / 2 \mathrm{~m}$ lb. $70 \mathrm{c}, 1 \mathrm{~b}$. $\$ 1.35$.

I.ivingston's Royal Red. A first-class main crop tomato for the shipper, market and private gardener. The beautiful red color of both skin and flesh of
the Royal Red is of special value for canners. Pkt, 4c, oz. 15c, $1 / 41 b .40 c$, the Royal Red is of
$1 / 2$ Ib. roc, $1 \mathrm{~b} . \$ 1.35$.

New Stone. The New Stone Tomato ripens for main crop; it is very large and f a bright scarlet color: exceedingly solid and firm fleshed. an excellent shipper: very best quality; fine for canning. Pkt. 3c, oz. 12c, 1/4 lb, 40c $1 / 2$ 1b. \%0c, $1 \mathrm{~b}, \$ 1.35$.

Iivingston's New Dwarf stone. A new fine sort. The strong upright growth permits of close planting, as near as 18 by 24 inches apart. Fruit large, beautiful shape, smooth, solid and of most excellent quality. Pkt. 4c, oz. $15 \mathrm{e}, 2 / 41 \mathrm{~b} .50 \mathrm{c}$.

Livingston's Aristocrat. This fine new variety in habit of growth and foliage resembles the Dwarf Champion, but the color is a glossy red. Medium sized, solid, productive, smooth and fine flavor. Pkt. 3c, oz. 15c, $1 / 41 \mathrm{~b} .50 \mathrm{c}$ Acme. One of the earliest and handsomest varieties introduced. Fruit medium son. Pkt, 3c, oz. 12e, $1 / 1 / 1 \mathrm{lb} .40 \mathrm{c}, 1 / 2 \mathrm{lb}$. 70c, 1b. \$1.35.

Paragon. A fine sort; deep red; one of the best; a valuable market sort. Pkt. $3 \mathrm{c}, \mathrm{Oz}, 12 \mathrm{c}, 1 / \mathrm{k}$ lb. $40 \mathrm{c}, 1 / 2 \mathrm{lb}$. $60 \mathrm{c}, 1 \mathrm{~b}, \$ 1.30$.

Perfection. Fruit medium large, almost round, enormously productive, is solid; has lough skin: very valuable for shipping. Pkt, 3c, oz, 12c, 1/4 lb. 40c,

Itlantic Prize. It is the most valuable market variety ever introduced. The fruit is borne in immense clusters, each vine producing from 60 to 80 large fruits, very solic

Early Ruby. Its style of growth is very open, the fruit being produced close to the main stem, hence its great earliness. Pkt. 4c, oz, 15c, 1/4 1b. 50c.

Livingston's Favorite. Large, uniform, early tomato, deep red, very solid, fine shipping solt. Plst. 3c, az. 12c, 1/1 1b, 40c, 1/2 1b, 70c, 1b. $\$ 1.30$

Vellow Pearshaped, Lised for preserving and pickling. Pkt, 3e, oz, 15e, $1 / 4$ 1). 50 (te

New Peach Tomatp. The rruit resembles the form and co'or of the peach; of a beautiful deep rose, blended with amber. Finf for eating out of the hand. Very productive. Pkt. 4c, 0z. 15c, $1 / 5.1 \mathrm{~b} .50 \mathrm{c}$

Ground Cherry, Husk or Strawberry Tomato. This is very much liked by many yellow Ground Cherry and is very prolific. Pkt. $4 \mathrm{c}$.

$7^{y}$

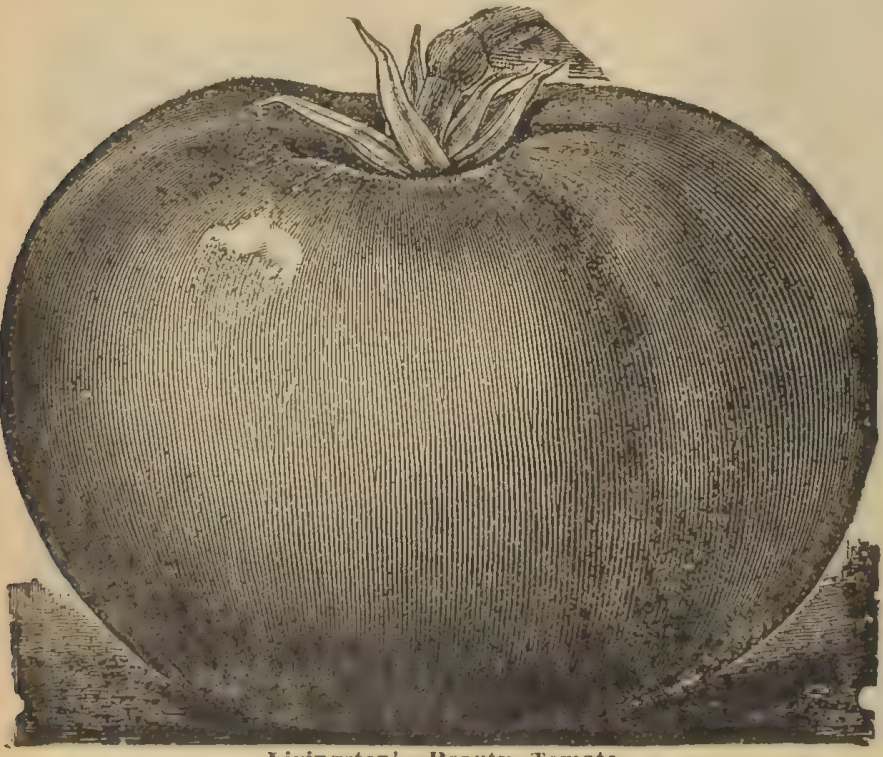

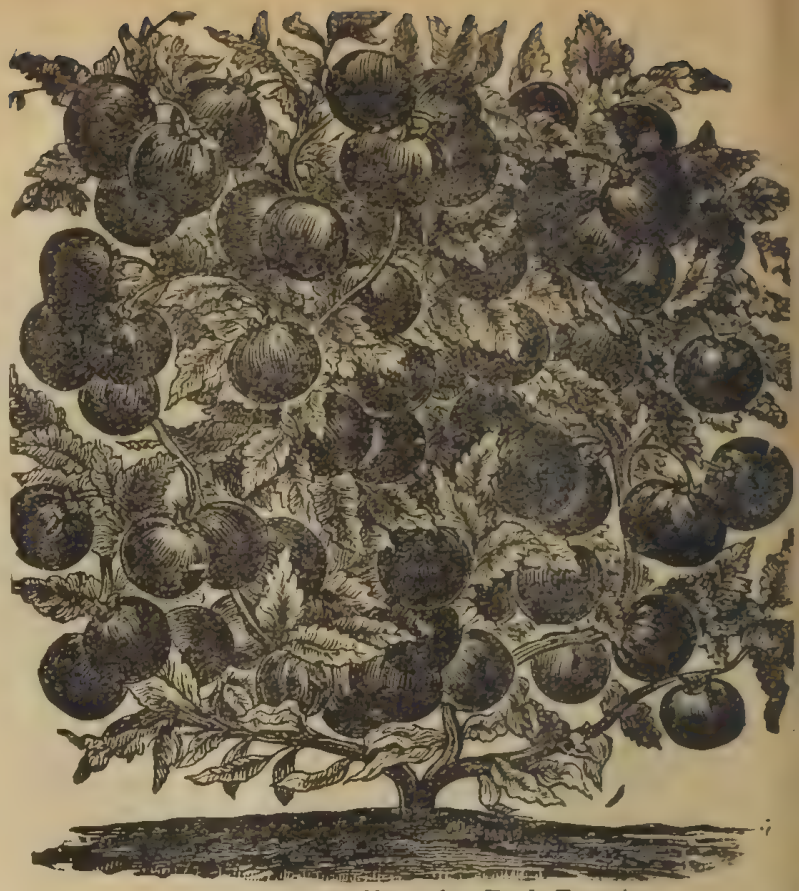

Alneer's Dwarf Champion Bush Tomato.

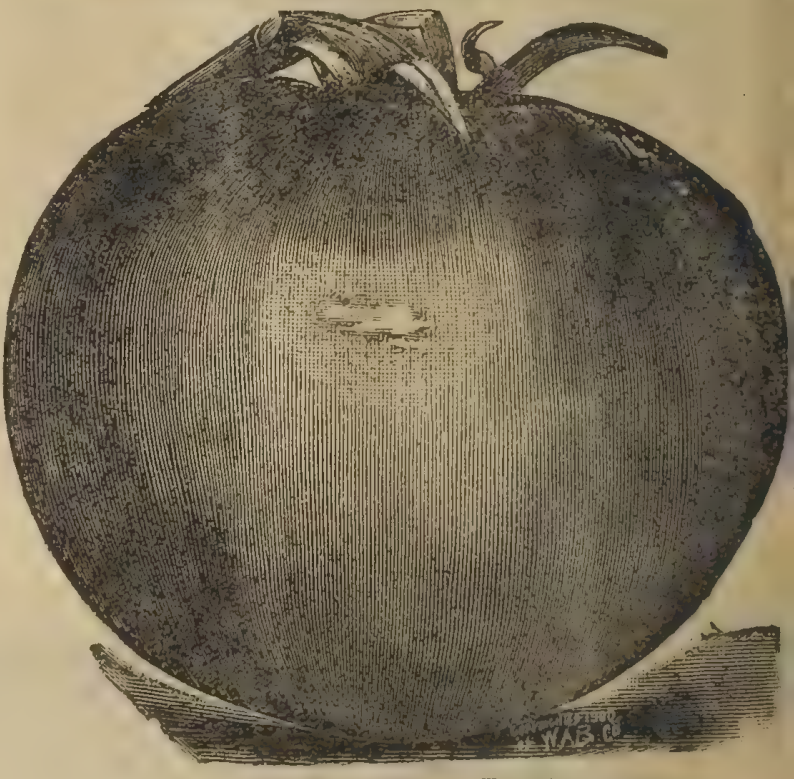

Chalk's Early Jewel Tomato.

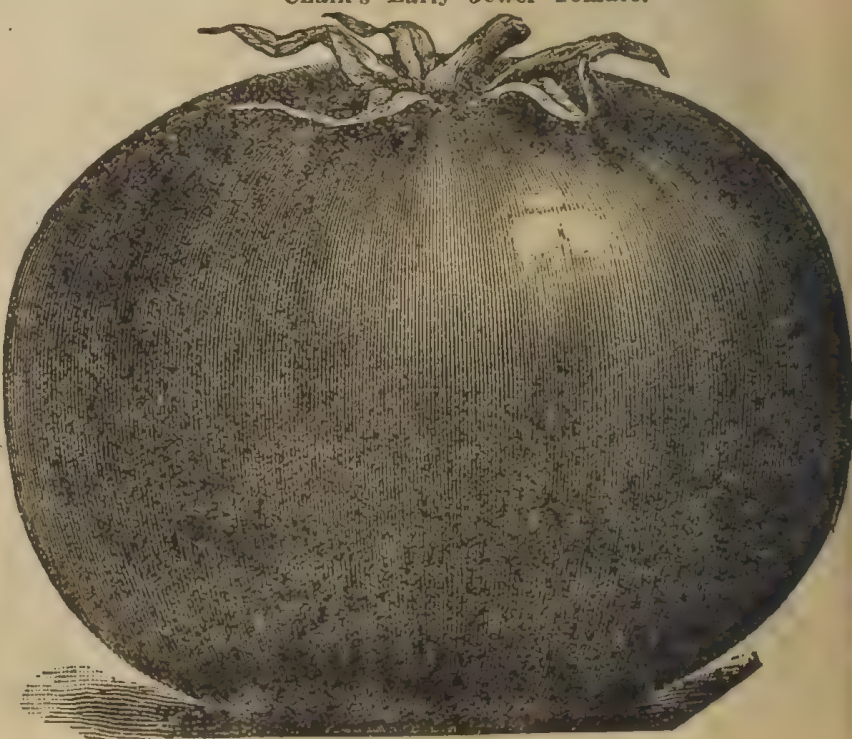

Spark's Earliana Tamato. 


\section{TOBACCO}

Connecticut seed reap. Pkt, $3 c$, oz. 20c, 1/s lb. $60 \mathrm{c}$.

Virginia Broad Leaf. Pkt. $3 c$, oz

Importei

Prize Mammoth Sunflower

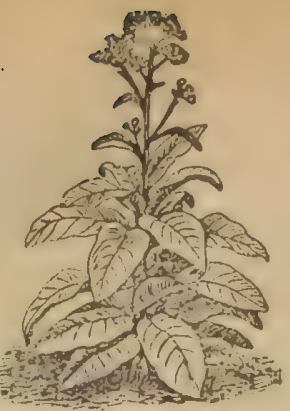

b. 20c. By express $1 / 8$ bu. $30 c$ $1 / 4$ bu. $50 \mathrm{c}$.

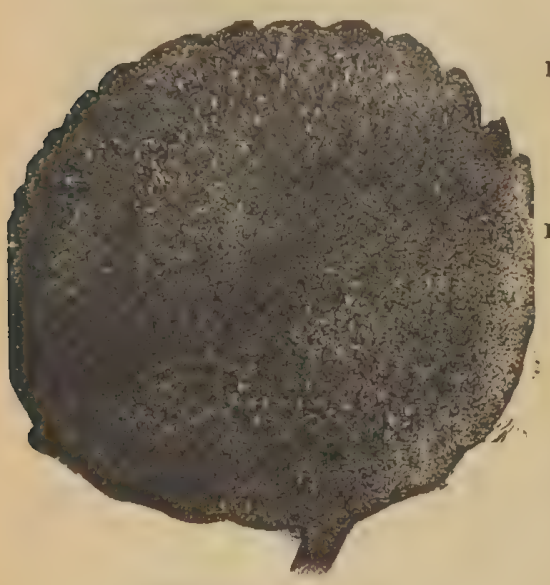

\section{SOR GHUM, or SUGAR CANE}

Improved Early Amber. The earliest varlety almost invariably

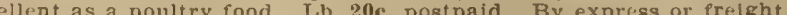

\section{BROOM CORN}

Broom Corn, Improved Evergreen. This is the most popular ra light ereen colorin when properly cure By express or freight, 10 lbs 60c, 25 lbs. $\$ 1.35 ; 100$ lbs, $\$ 4.00$.

\section{TEOSINTE}

Recommended as the most prolific forage intro duced The stalk, containing much gaccharine nutritious ing enormously. One cee will sometimes produce 20 to 60 stalk or shoots, and the warmer the climate the better it ylelds. not be planted until the soll is perfectly warn in the 3 feet apart, and 2 or 3 seeds every 12 inches in drill. Oz. 10c Mammoth Sunflower.
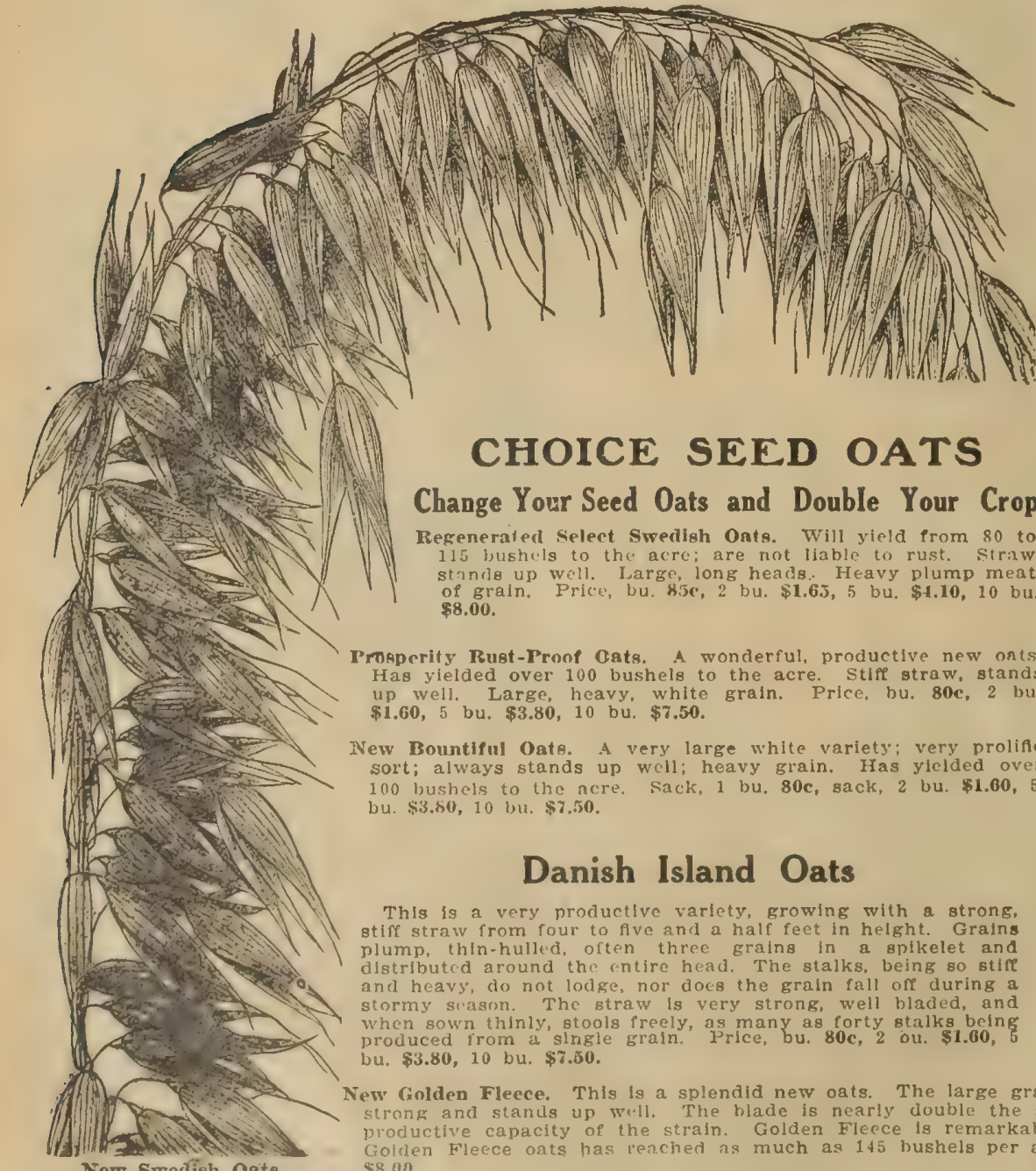

CHOICE SEED OATS

Change Your Seed Oats and Double Your Crop Regeneraied Select Swedish Oats. Will yield from 80 to stindla up well. Large, long heads. Heavy plump meat of grain. Price, bu. \$5c, 2 bu. \$1.65, 5 bu. \$1.10, 10 bu. $\$ 8.00$.

Prosperity Rust-Proof Cats. A wonderful, productive new ont Has ylelded over 100 bushels to the acre. Stiff straw, stands $\$ 1.60,5$ bu. $\$ 3.80,10$ bu. $\$ 7.50$.

New Bountiful Oats. A very large white variety; very proliffe sort; always stands up well; heavy grain. Has yiclded over bu. \$3.80, 10 bu. $\$ 7.50$.

\section{Danish Island Oats}

Now Swedish Oats.

productlve vartety, growing with a strons. thelght. Grains and heavy, do When sown thinly, stools freely, as many as forty stalks being $\$ 8.10$.

Calhan, Colo.
Gentlemen:
I have bought
seeds of you for
twenty years and
have a I w y 8
found them first-
class, and there-
for will be glad
to recommend
you to all of my
nelghbors.
Jacob Samson.

\section{VETCHES}

Sandvetch. (Winter Vetch. Another forage plant fro Europe, highly esteeme there. The Sandvetch pros pers in the most barren soil on those too poor to grow th Winter tare. Six tong pi been harvested in one cl in poor silicious soils wit gecond cut for seed in Ai cust alone or with a ceres ye preferred, as this vetc 5 feet, and must have a 3 u port. Sow 60 to 75 poun gere. If good growth b ore winter, it may be cu and azain by March 15 30c. at buyer's expense: lus. \$1.2.5, 25 ibs. \$3.10. lbs. \$6.00, 100 lbs, \$12.00.

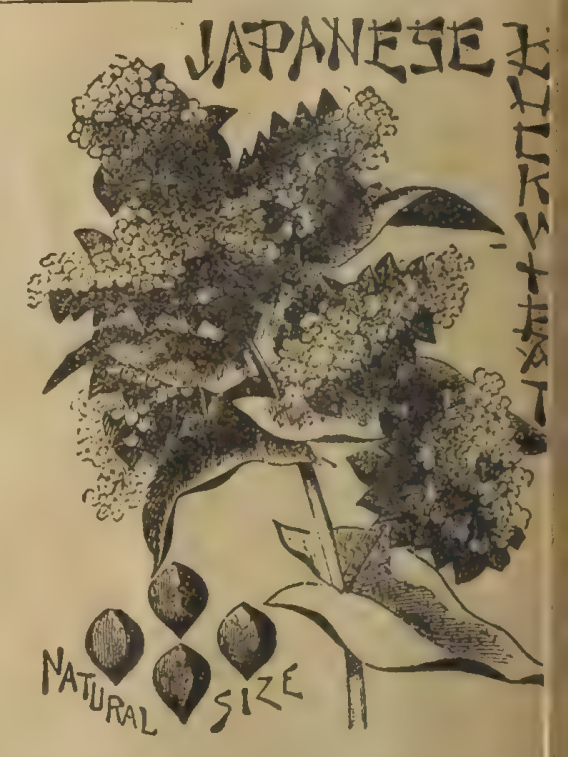

Burkwheat-New Japaneae. Should be :0 the middle of June, using from one tor th prcks of seed per acre. This now sort proven to be much earller and more prod tive than any other variety. Grains vi large and of rich brown color. It excels bu. $30 \mathrm{c}, 1 / 4$ bu. $50 \mathrm{c}, 1 / 2$ bu. $85 \mathrm{c}$, bu. $\$ 1.60$.

New Golden Fleece. This ls a splendid new oats. The large graing are plump and handsome. The straw is productive capacity of the strain. Golden Fleece is remarkable for Its grcat stooling capacity. The yleld 


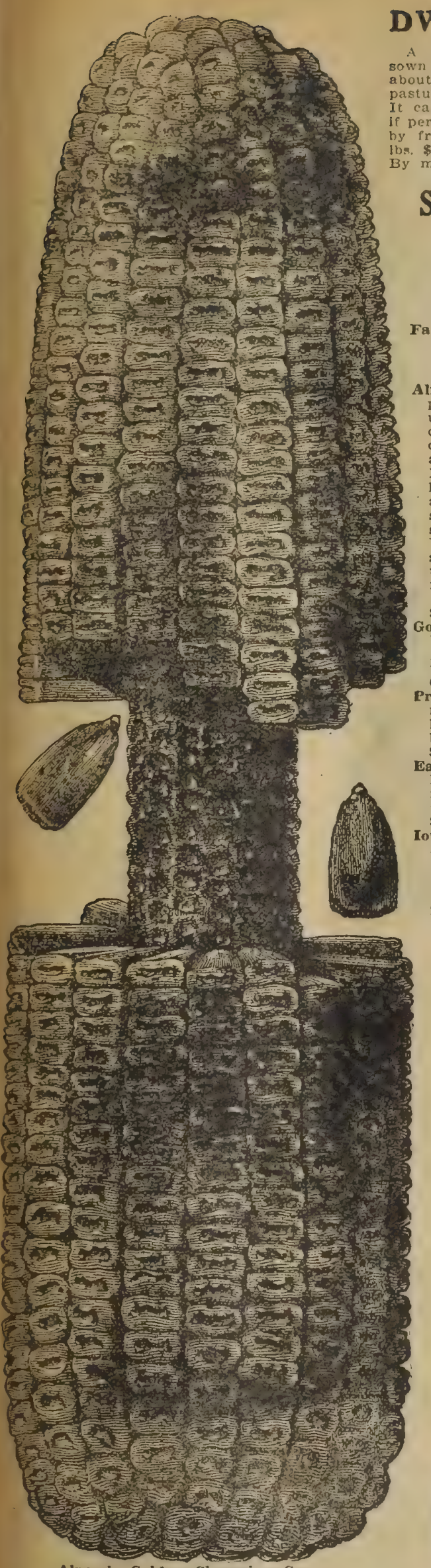

Alneer's Golden Champion Corn.
DWARF ESSEX RAPE

$\$ 8.50 ; 50$ lbs. $\$ 4.30 ; 25$ lbs. \$2.25; 10 Ibs. $\$ 1.10$

\section{SELECTED FIELD CORN}

QUARTS POSTPAID.

Fand Plcked, Tipped, and Butted.

Northern Grown.

Farmers, Change Your Seed Corn and Raise Big Crops.

\section{Alneer's Golden Champlon. The great}

ular and most uniformly distinct type

careful selection has resulted in remark-

able evenness in appearance of ears.

lows: Ears accurately described as rol-

per 18 to 24 rows with narrow

the well flied at butt and tip.

trown from pedigree seed selecin competition. Price shelled, qt. 25e; $\$ 3.90$.

Gold King Corn. Decldedly the finest New grain: corn. Has large, fine ears, deep money maker. Price, qt. 25c; $1 / 4$ bu. Pride of the North. Yellow Dent. Eighteen rowed; ears elght to nine inches in bu. 60e: $1 / 2$ bu, $\$ 1.10 ;$ bu, $\$ 2.00 ; 2$ bu. bu. 60c; $1 / 2$ bu, $\$ 1.10$; bu. $\$ 2.00 ; 2$ bu. Early Mastodon. (Grown by originator.) New Yellow Dent, largest and earliest to the acre, Qt, 25c; $1 / 4$ bu, 60c; $1 / 2$ bu. $\$ 1.10$; bu. $\$ 2.00$; bu. $\$ 3.90$.

Iowa Gold Mine. Early; ears of good size and symmetrical, color bright golden yelwo pounds ear corn makes sixty pounds $\$ 1.10$; bu. $\$ 2.00 ; 2$ bu. $\$ 3.90$.

Iowa Silver Mine. (White Dent.)

derful producer has pure white kernel and a very small white cob. Ears contain bear two ears. Matures in about 100 days. Qt. 25c; $1 / 2$ bu. 60c; $1 / 2$ bu, $\$ 1.10$; bu. $\$ 2.00$ 2 bu. $\$ 3.90$

strain of this splendid variety to
this season. It is a very strong
with heavy fodder and largo ears.
grain has white cap with lemon
body. An enormous ylelder. bu. 60c; $1 / 2$ bu. $\$ 1.10$; bu. $\$ 2.00 ; 2$ bu. $\$ 3.90$ Improved Leaming. Dent variety. Ears of ears to each stalk tures early; a good yielder. Qt, 25e: 1/ Early Yellow Yankea Flint Corn. Fias lon makes nlce roasting ears. Is a fine mill Ing sort. Qt.
$\$ 1.10 ;$ bu. $\$ 2.00$.

Calieo. A beautiful and most remarleabl color type of corn, being red-amber, foldears, good yielder, $1 / 1$ bu. $60 \mathrm{c}$; $1 / 2$ bu. $\$ 1.10$; bu. $\$ 2.00$; 2 bu. $\$ 3.90$.

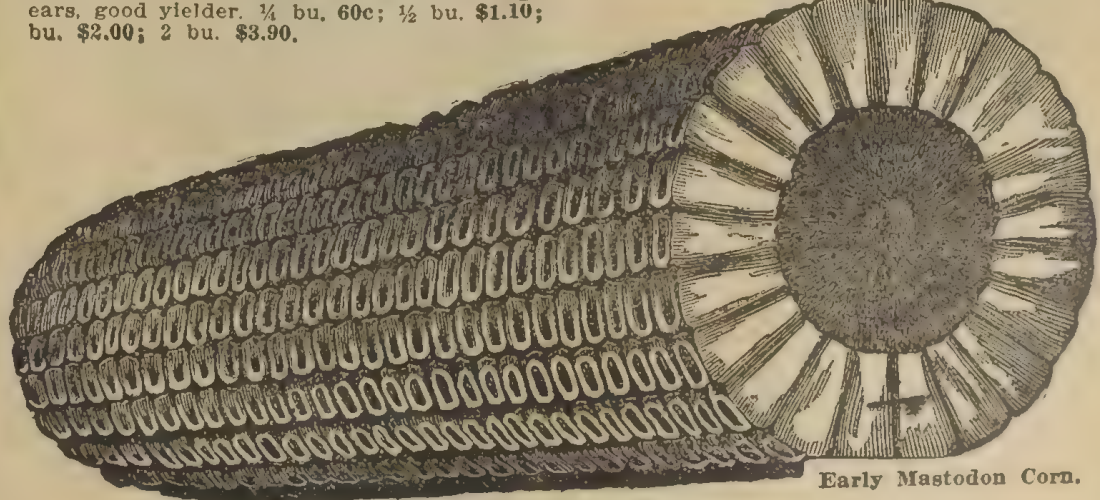




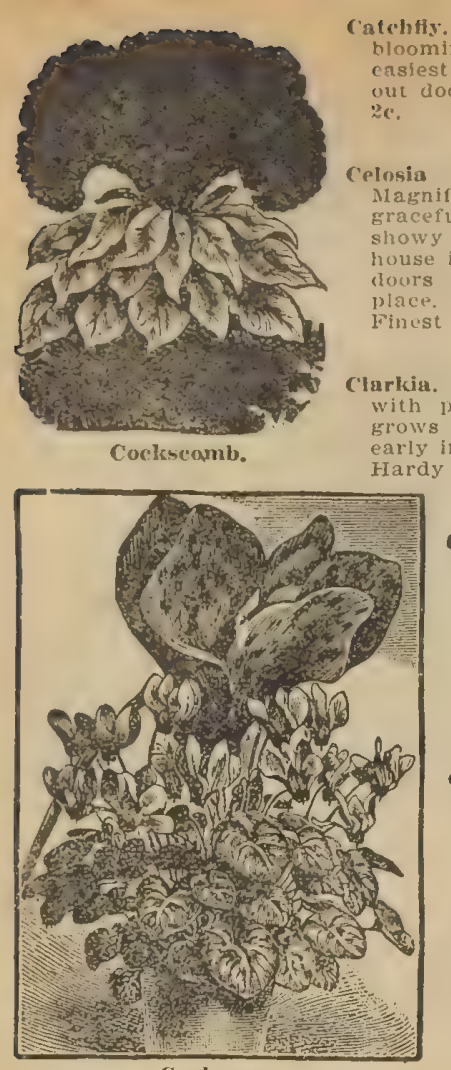

Cyclamen.

Centranthus. Free-flow-

ing plants with num-

erous clusters of pink

Hardy annual. Mixed

pkt. 2e.

Cotton. Fine curiosity

blossom freely, and

will ripen the pods

started early and set

out in warm weather.
They look masnificen

in the garden as soon

as they open the bolls

Crclamen. One of the choicest of all the

greenhouse or window plants. Root bulbous
in shape; foliage rich and beautiful"; flow-
ers bird-like and fragrant. Colors, white,
pink, crimson, etc. Should be sown in light

Persicum. Choice mixed. Pkt. 10c.

Cacalia. (Tassel Flower.) A fine and profuse

low tas plant, producing scarlet and yellow tassel shaped flowers, treat
Hardy annuals. Mixed pkt. 2c.

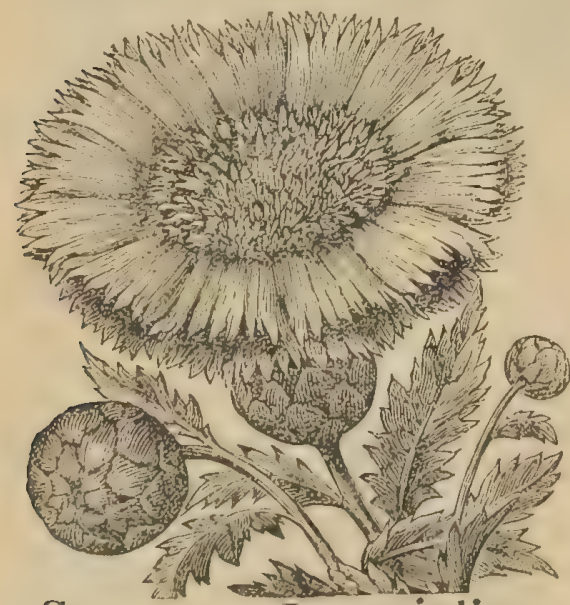

\section{Centaurea Imperialis.}

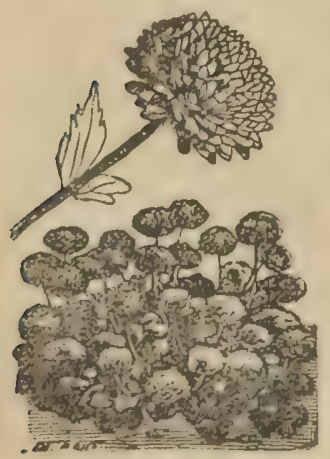

Double Daisy,
Coleus. Easily grown from seed. Choicest varietics. Mixed, pkt, 8c. Cypress Vine. Finc ornamontal climber, with delicate fern-like
follage. Sow secd in March. transplant to open ground in May. follage. Sow secd in March. transplant to open ground
Half hardy annuals. Scarlet, pkt. ke. Mixed, pkt, 3e.

Daisy-Shasta. A hardy perennlal bearing large pure white nowers, sometimes four inches in diameter, in grcat profusion on long stiff

Daisy-Double. (Bellis Perennis.) A well known and favorfte Start in house In April. Half hardy annuals. Cholcest Double Start in house In April. Half hardy annuals. Cholcest Double
Mixed, pkt. 5c. New African Golden-Orange Daisy. The single dalsy llke flowers
are $21 / 2$ inches in diameter, has glossy terra cotta orange flowers very brillant and showy. A bed in full bloom is truly a magnificent sight. Will bloom the entire summer. Pkt. 5c.
Convolvulus vajor. ( T' a 11 Morning and blonm freely in almost any sit untion. Soty seced about open ground Tall, mixerl colors. Pkt. 3e; oz. 10e.

Convolvulus Minor. (I) w a $r$ H Mrning (ilory.) MIIxed

Clematis Jacknami. Very large llowers (4 to 6 inches) etc. The popular hardy elimber, an old favorite. Plkt.

Clematis Paniculata. glossy, green leaves, never troubled by ins sunshine or shade. Small star llke fragrant fowers, grows to a height of 30 feet. Packet,

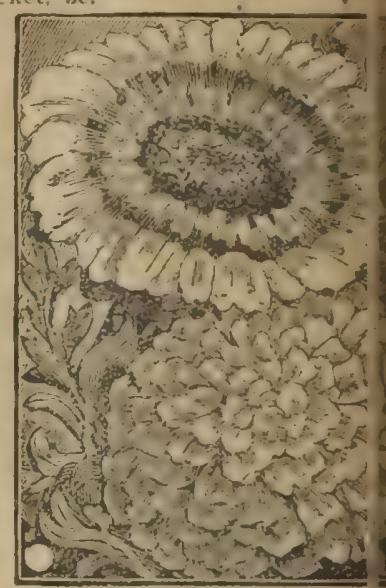

Chrssanthemum Mixed.

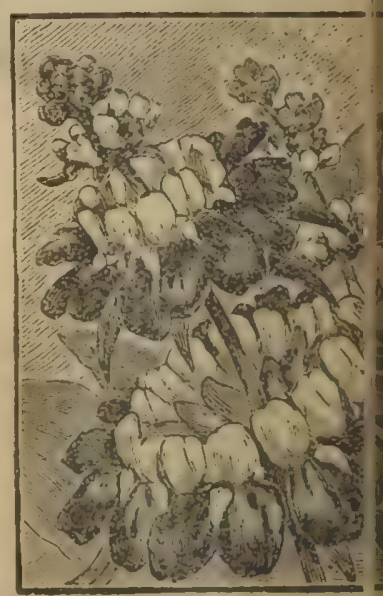
Cowslip.

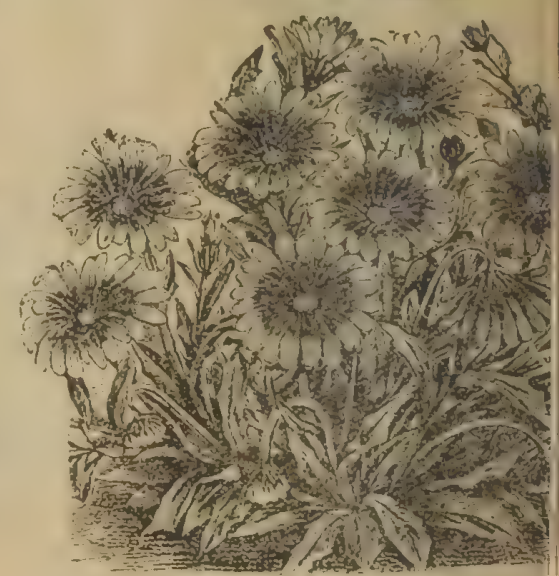

New African Golden-Orange Daisy. 

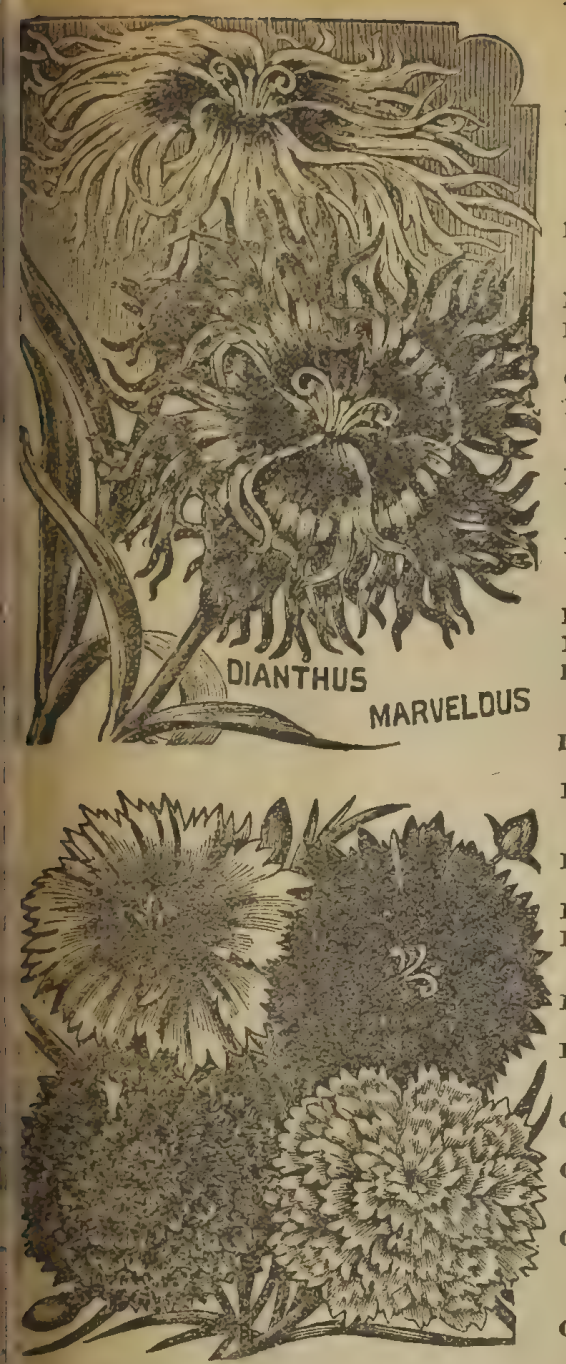

Dianthus-Mixed Pinks.
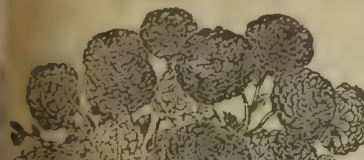
first and sccond seasons; unsurpassed in brilliancy of color and proruslon of bloom. Sow seed in house in AprIl; out of doors in May. Hardy annuals.

Marvelous. (Dianthus Laciniatus Mirabilis.) The flowers are single with exceptionally large decply fringed petals measuring two and one-half to three inches across the fower. The fringed edges are to richest crimson. Fer pkt. 10c.

Diadematis. Dladem Pink.. True; fine extra double. Our strain of this beautifui pink is unrivaled in slze of flowers and variety of colors. Pkt, 10c.

Heddewigii. Double Mixed, pkt. Sc

Laciniatus Flore Pleno. Beautiful double fringed variety; very fine. $5 \mathrm{c}^{\circ}$

Cboicest Mixed, pkt. 4c.

Perpetual-Flowering Pinks. (Plumarius Flore Pleno.) The old fashdouble hardy varietics, having a stron clove fragrance pkt 10c.

Datura Wrightii. (Trumpet Flower.) Hardy annuals, with purple and white trum
Pkt. 3c.

Dahlia. Seeds saved from a large collection of best Dahllas and are plant out in garden about May 15 th. Half hardy perenmials.

Double Finest Mixed, pkt. $8 c$.

New Single Mixed, pkt, 5c.

Delphinium. (Larkspur.) Delights in cool soil and shade; in many varicties and color
Mixed, pkt. 3 c.

Digitalis. (Fox Glove.) Exceedingly showy and ornamental plants of stately growth and varied colors. Hardy perennials. Fine mixed, pkt. $3 \mathrm{c}$.

Erysimum, Very showy, free-flowering plant with yellow flowers effectlve in beds and mixed borders. Hardy annuals, $2 \frac{1 / 2}{2}$ feet high.

Eschscholtzia. (California Poppy.) Exceedingly profuse blooming low flower. Sow in open gruund in May. Hardy annuals. Pkt. $3 \mathbf{c}$.

Eschscholtzia (Burbank's Crimson.) Pkt, 10c.

Echinocsstis Lobeta. (Wild Cucumber,) Quick growing and pretty climbir; great favorite for covering trellis, stumps, etc. Pkt. 4e; Fererfew Double White. (Alba Plenissima.) The finest pure white Feverfew. (Pyrethrum Roseum.) The flowers of this kind are gathder." dried an

Gilia. Pretty dwarf annuals; will bloom in any situation: good for massing. Fine mixed, pkt, 2c.

Globe Amaranth. (Gomphrena.) Handsome, everlasting, with showy flowers. The flowirs should be cut in summer and preserved for winter bouquets. Half hardy annuals. Pkt. 3c.

Geranium. These well known favorites are indispensable for outdoor as well as indoor decorations. Sow seed in shallow boxes in March; when large enough transpe mixed, pkt $10 \mathrm{c}$

Godetia. Handsome and showy annuals, bearing freely large flowers three to four inches across, of exquisite colors that glisten in the sun like satin. Fine mixed, pkt. 3c.

A bulbous rooted plant, producing in great profusion; has large well shaped mixed, pkt. 10c.

Gaillardia. One of the most showy and brilliant of garden flowers, fine for bedding and cutting, producing large flowers of

Grasses (Ormamental). The ornamental grasses are very showy and pretty, and when dried and arranged in connection with everlasting flowers mak when dried and arranged in connection with everlast

attractive winter bouquets. Sow in open
All Varieties Grasses. Mixed; large pkt. 5c.

GOURDS. Ornamental fine and curious.

GOURDS. Ornamental, fine and
fences, etc. Mixed, pkt. 4c.

Luffa or Dish Cloth. The peculiar lining of this lastic and durable makes a natural dish

\section{(ong; the vine is very ornamental, with clusters of}

ladies prefer this dish cloth to any other. Pkt. bc.

ugar Trousta

True Japanese Nest Egg Gourd

rapid grower, Pkt. 4c.

Dipper Gourt, A valuable ho and necks grow straisht pkt 4c.

Irelianthus (Double Dwar Sunfower). edding put kown seed for use fowering habit, excellent for

Double Dahlias.

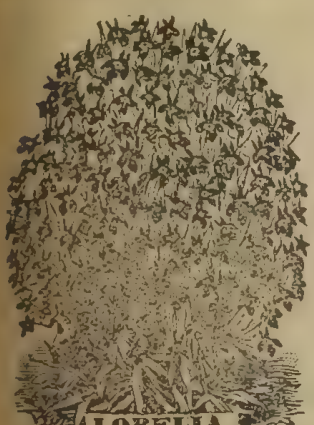

ne mixed; pkt. 5c.

Iollyhock. A most splc

louble as roses, of every shade and

Where they are to binest double mixed; pkt. 5e.

Helipterum. (Sanfordi,) Everlasting flower. Pkt. 3c.

llelichrysum. (Everlasting Flower.)

Menstrisum, Double Mixed; pkt, $3 \mathrm{c}$

Ice I'lant. (Mesembryantliemum,) A fine littlo trailing plant with star-ifke flowers in great a

Ipomolsis. (Tree Cypress.) Handsome, free-flowering plant with spikes o deepest orange and scarlct flowers. Tike heads, color very brilliant and constantly changing in

Linum (

Cow seed in the open ground. Pkt. 2e.
Lobelia. Very fine growing plant, admirable for front lines of ribbon borders and vases and hanging baskets. Flowers deep blue and
glass. Half hardy perennlals. Cholce mixed; pkt. $3 c$.

Crystal Palace Compacta. Rich, deep blue, with dark follage. bedding. Pkt. 5c.

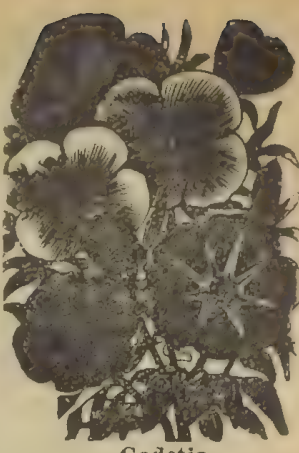

Godetia.

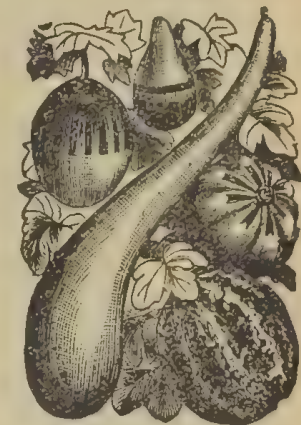

Mixed Gourds.

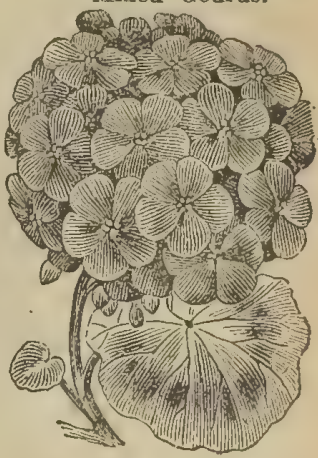

Geranium.

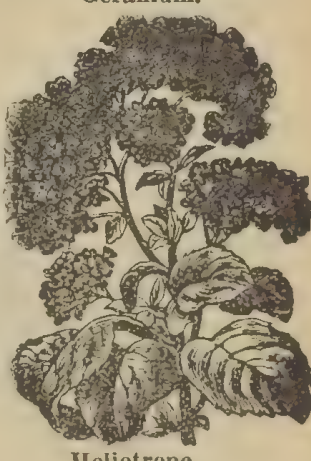

II eliot rope.

(a) $3 y^{7}$ 40 ? 3 ?

$3 y$ ind

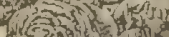

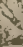

(t)

m.

$4=3,4=1$,

tin

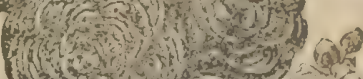

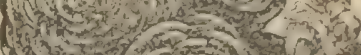

(1)

Double Hollyhoek. 


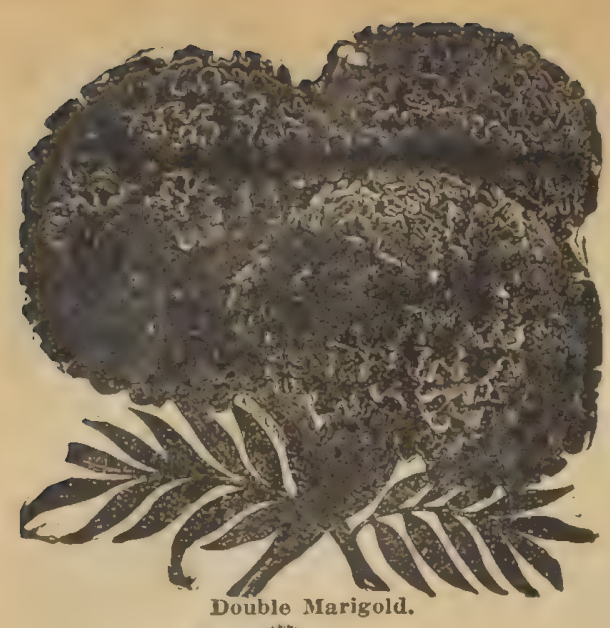

long and A rroef howering plant, bearin

and varied colors Hardy annuals.

Iychnls. Very handsome, useful per

May in partial shade. Choice mixed:

pkt. $3 c$

Marigold. A well known free nowering

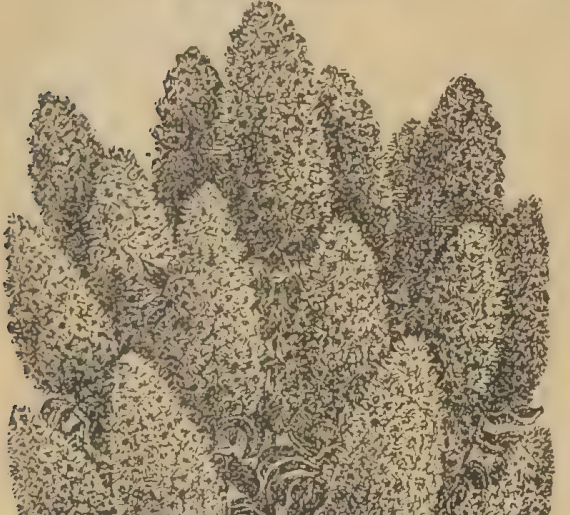

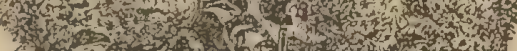

40 and

\&.13. IMIGNONETTE

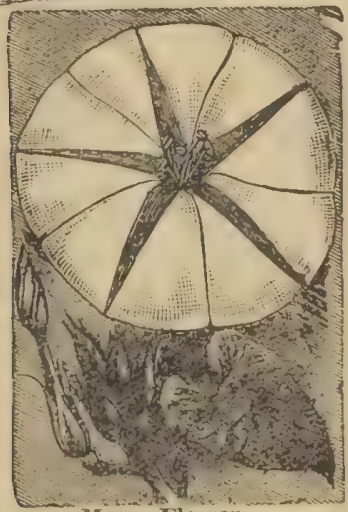

Moon Flower.

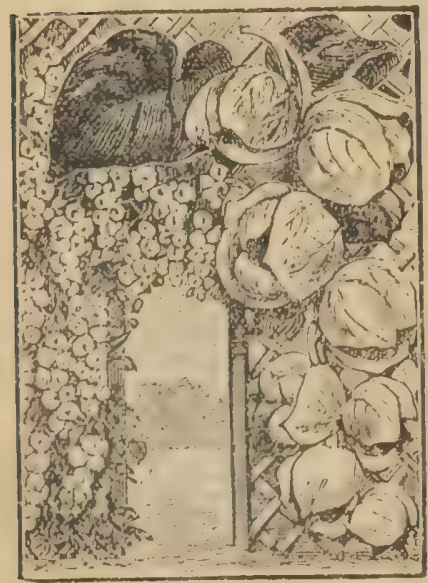

Moon "Flower (Ipomoca Noctiflora or Evening

Marvel of Peru. (Four O'Clock.) Beautiful both

inganding in the evening, wlthering next morn-
ing; color white, yellow, variegatcd; two feet.
Mixed; pkt. 3c.
Mountain Beauty. Tender Perennial Climber. Antigonon handsome climber of Mexican origin.

Flowers of brightest
clusters. Pkt.

Nicotiana Sanderae. The plants form a cluster of rich dark green leaves, from which strings o

covered with brilliant flowers which continue until

Fer pkt. 10c.

ering plant, admirably adauted for rock work. Sin

Alneer's New Giant Flowering. Eripipe.

Fmpress of India. Dark foliage with crimson and dark

Nasturtium. Dwarf; mixed colors. Pkt, 3c; oz, 6c: 1/s lb.
$20 \mathrm{c} ; 1 \mathrm{~b}$. 65c.

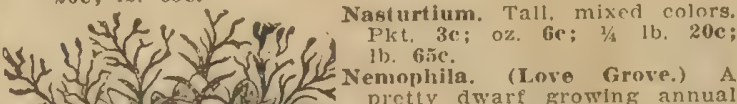

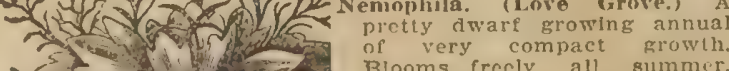

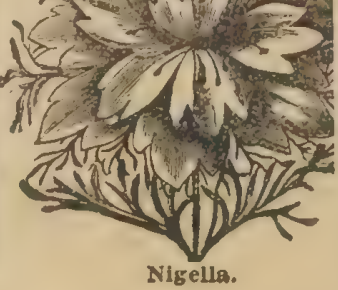

Hardy annuals. Fine mixed:

Nierembergia. Very fine plants:
adapted for baskets and edgIngs. Pkt, 5r,
(Love in a Mist.) Cur lous free flowering plants have most interesting looking
flowers. Will grow in any flowers. Will grow in any
goll. Sow in open ground in May. Half hardy annuals. Mixed; per pkt. 2c.

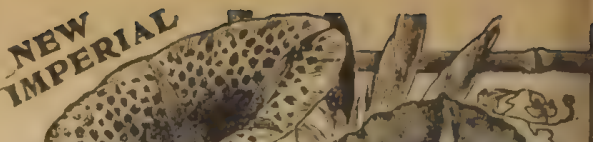
(a)

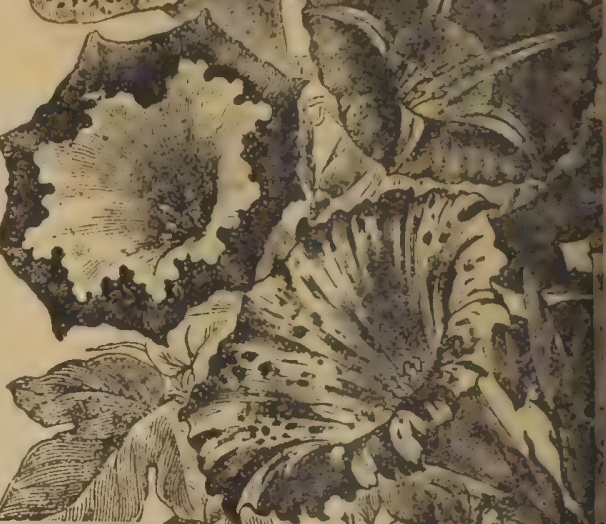

JAPANESE MORNING GLORIIES.

Iorming Glory, Imperial Japunese. The surpast charm of these improved Imperial Japanese Morr size of the flowers, they measuring from 4 nches across. The colors of the flowers, shac nature of such incomparable beauty that de tions are inadequate. Are of easiest culture. early to good rich soil. All colors; finest mi Iorning Glory. Finest mixed, 20 feet. Pkt. $3 \mathrm{c}$; oz. flower; a great favorlte for baskets and wh loaming. Per pkt. $4 \mathrm{c}$.

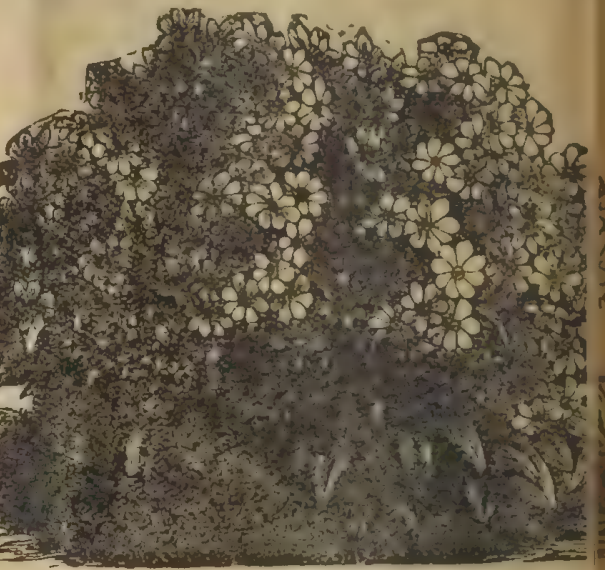
lorget-Mes-Not.

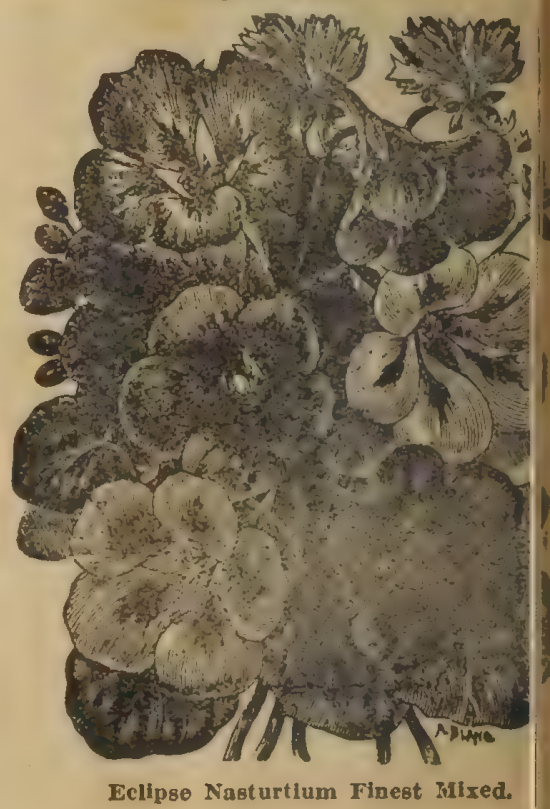





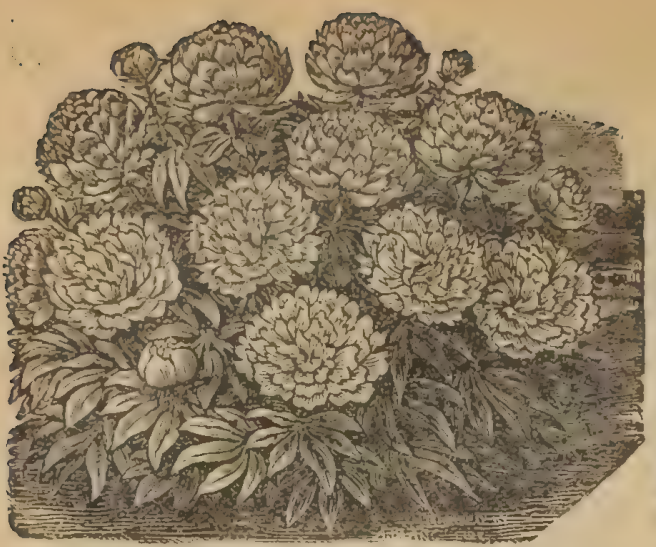

Paeony Double Mixed.

Paeonies. (Paeonia Herbacea Chin(ensis.) Well known herbaceous perennial pla
Erown either beauty that they should have a thrce feet high. Double mixed;
pkt. $8 \mathrm{c}$.

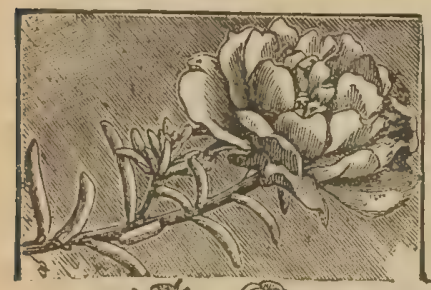

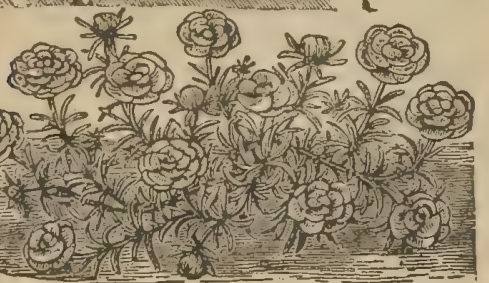

Double Rose-Flowered Portulaca.

Portulaca. A most brilliant and profuse

Ricinus.

Venus.

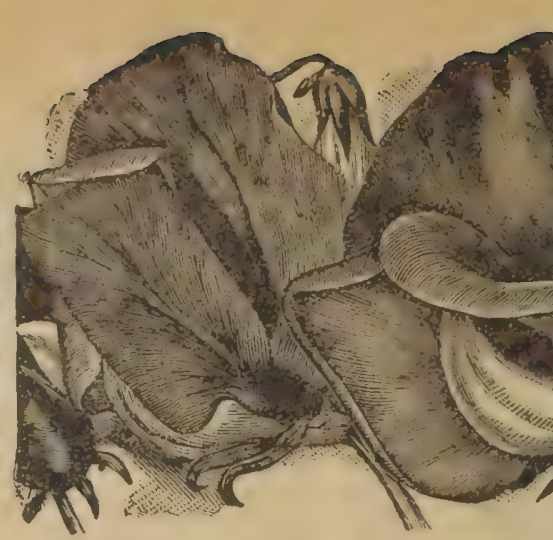

Rhodanthe. (Maculata.)

SWEET PEAS.

support by stakes.
Alneer's Prize Giant Flowering.

Alneer's Prize Giant Flowering. Very fine. Pkt. 5c; oz
$10 \mathrm{c} ; 1 / / 4$ ib. 25c.

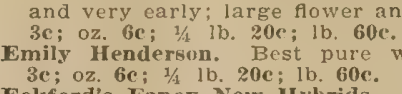

Eckford's Faney New Hybrids.

$1 / 4$ lb. 20c; $1 / 2$ b. $35 \mathrm{c} ; 1 \mathrm{~b} .60 \mathrm{c}$

Finest Mixed Colors. Pkt. 2c; oz. 6c; 1/4 1b. 20c

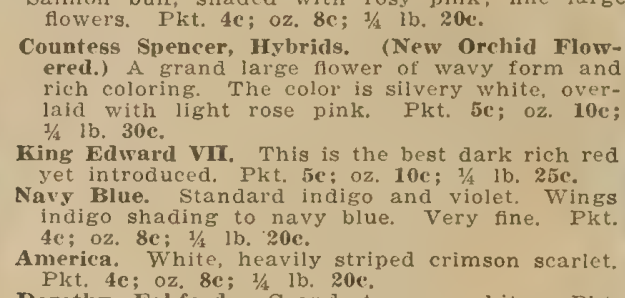

Dorothy Eekford.

New Double sweet Peas.

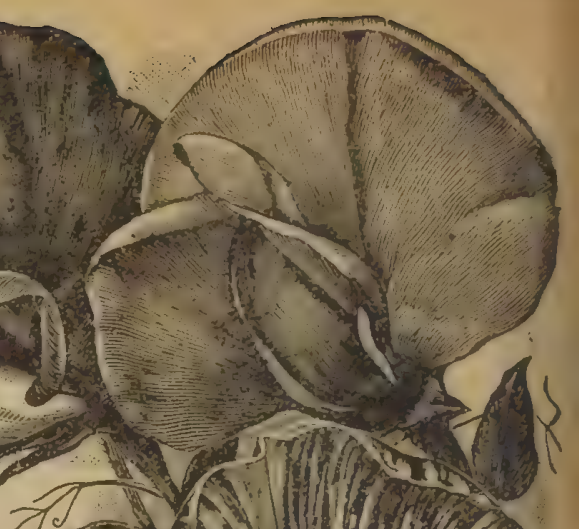

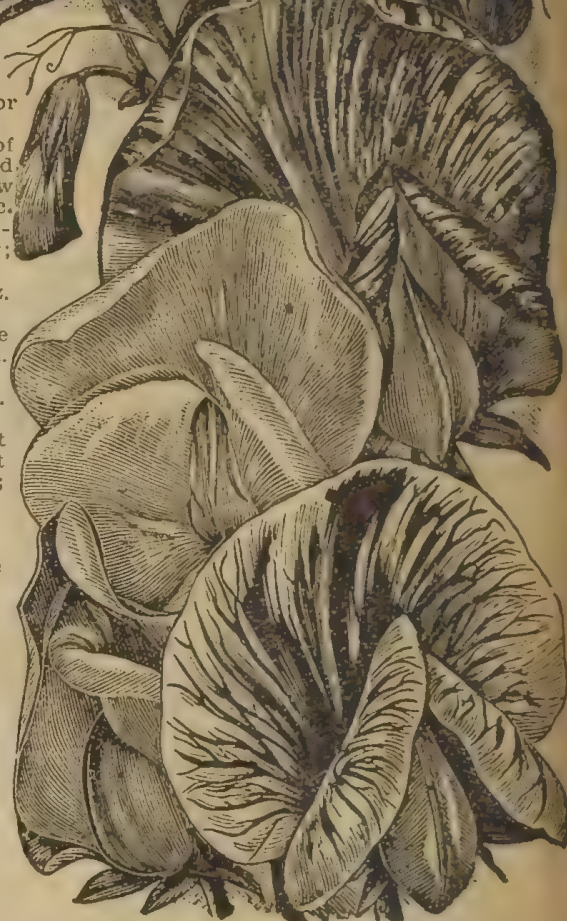

Eckford's Fancy Sweet Peas Mixed. annuals in cultivation; fotvers double as

sunny place. Sow , light soll, in warm Double Rose Flowered. Mixed. Pkt. 5c.
Single Mixed. Pkt. 3c.

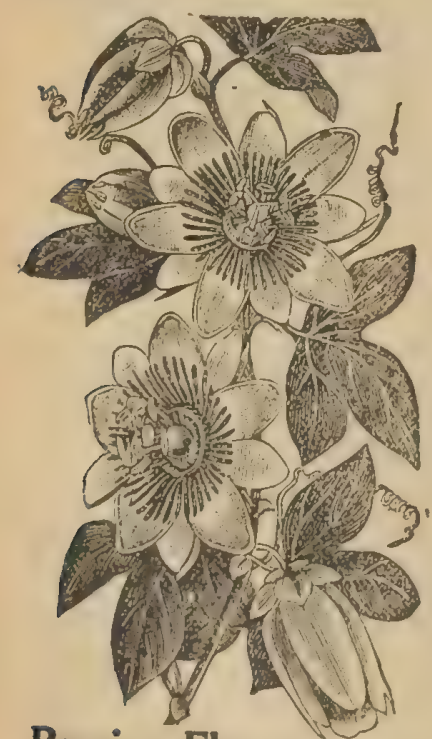

Passion Flower

Passiffora or Passion Flower.

ing singularly

Mixed, pkt, бc.
Salvia. (Flowering Sage.) Fine

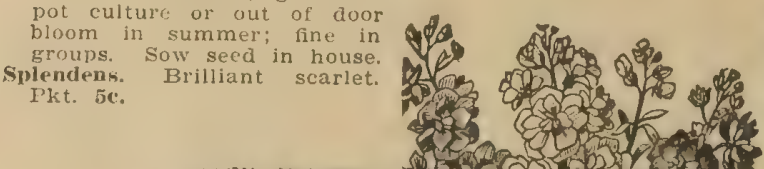

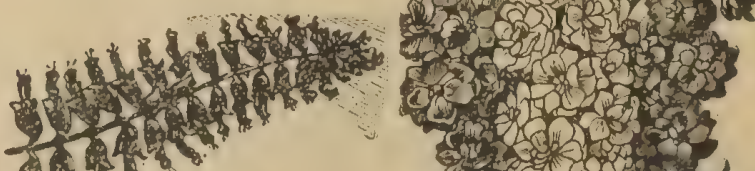
\& 3425

or 13

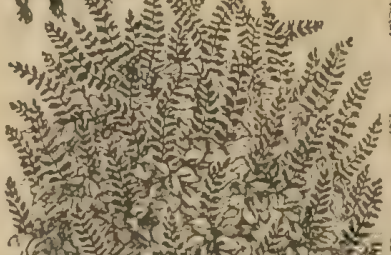

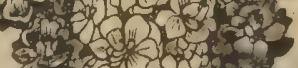

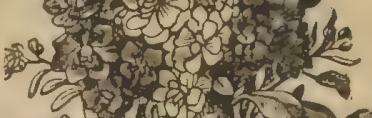

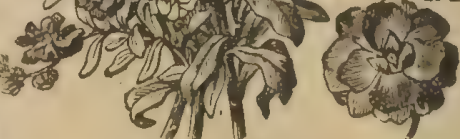

German Ten Weeks Stocks.

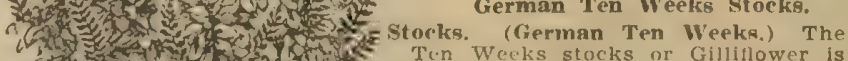

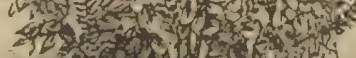

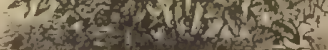

Salvia Splendetis set out in open ground.

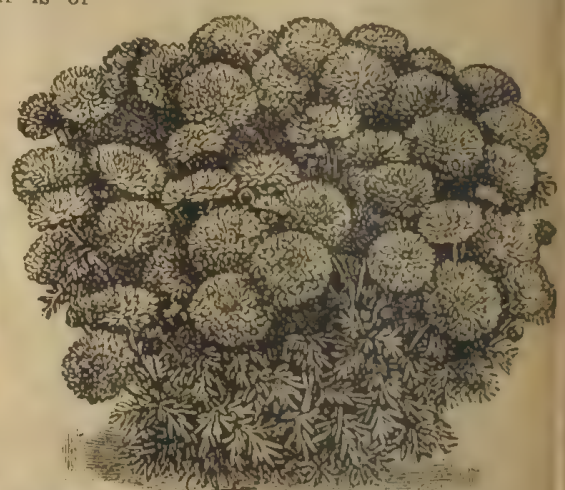

N I W BA B Y GOLDEN GLOW.

Stokesia Cyanea. Valuable hale hardy perennfal two feet high. blossoms. Also called Cornflow across. Culture easy. Plst. 10e. Rudbeckia Baby Golden Glow. Golden Queen. A most charming annual growing about 15 to 18 inches high,
bearing scores of bright yellow double flowers. The plants begin to bloom almost as soon as set in thr open ground, affording an almosi $10 \mathrm{c}$ 



\section{Flowering Bulbs and Tubers}

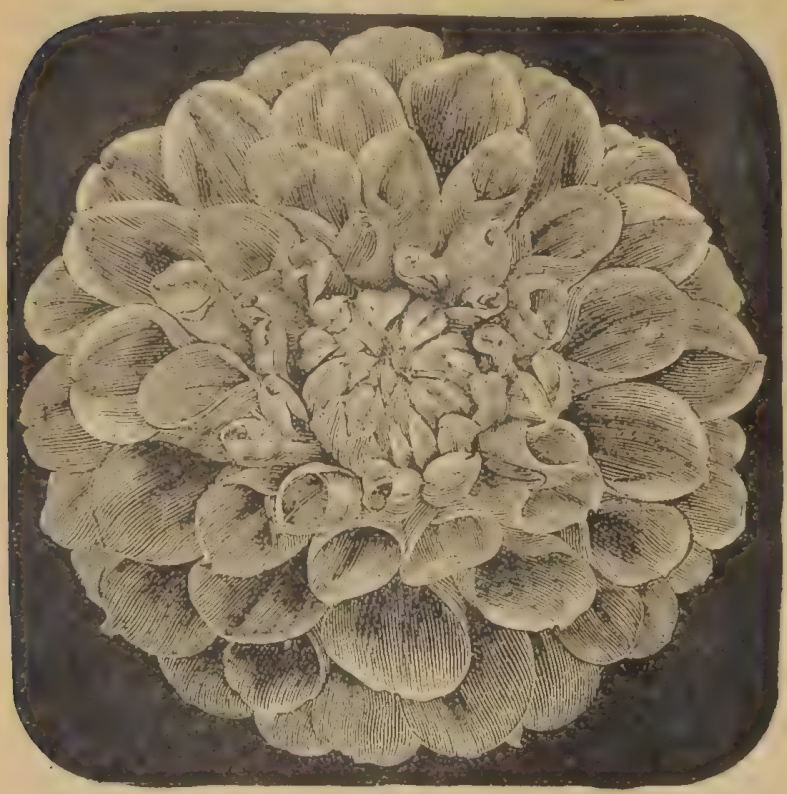

GIANT FLOWERING DAHLIA.

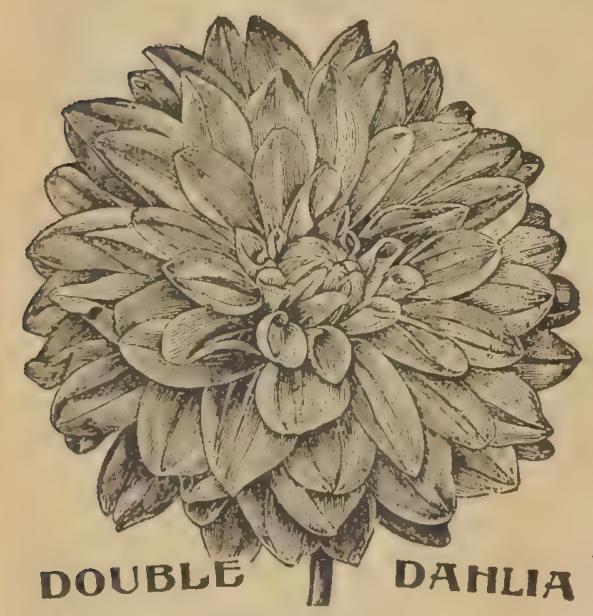

DOUBLE DAHLIA.

Dahlias,

Dahlias. Finest

with $60 \mathrm{e}$

DIELYTRA or DICENTRA (IBleeding Heart)

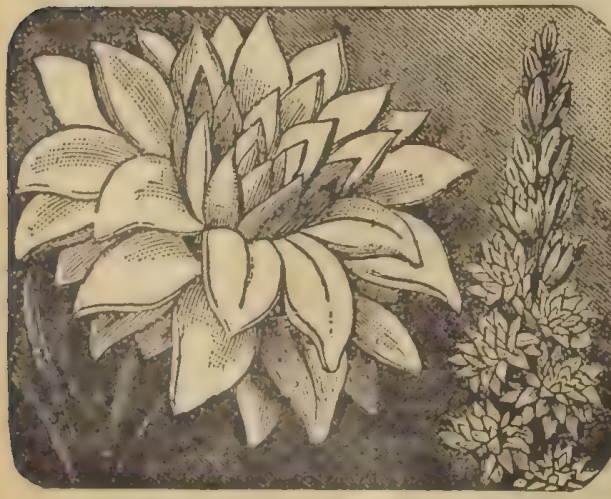

EXCELSIOR DOLBLE PEARL TCBEROSE.

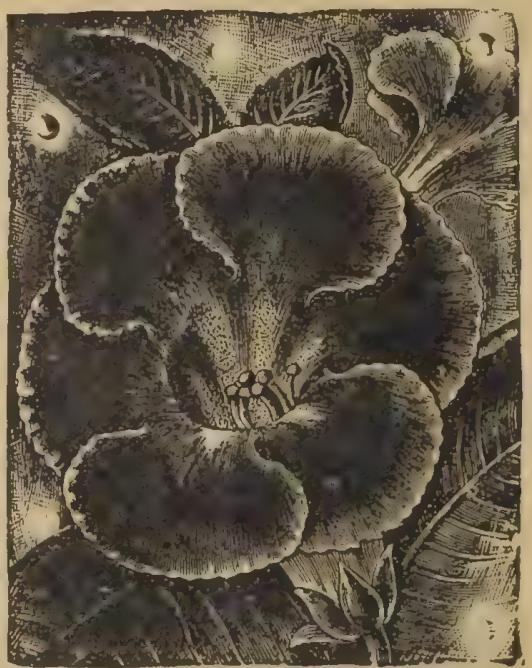

GLOXINTA.

Gloxinia Bulbs.

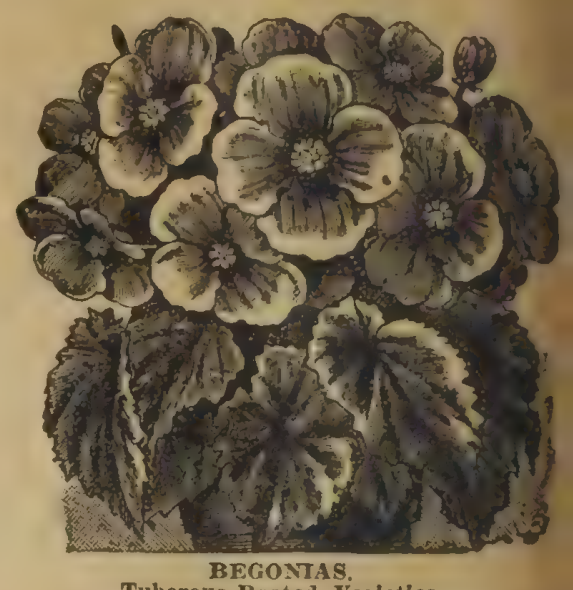

BEGONTAS,
Tuberous-Rooted Varleties.

Single Tuberous-Rooted Begonias.

Among the brightest bedding plants and well White, Rose, Scarlet, Yellow. Mixed Double Tuberous-Rooted Begonias. As avalable as the single-flowering sorts for White, Rose, Scarlet, Yellow.

$12 \mathrm{c}$ each, 4 for $45 \mathrm{c}, \$ 1,25$ per doz postpaio Mixed. All colors. $\$ 1,00$ per doz. postpaid.

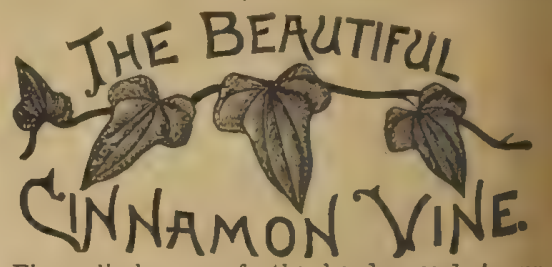

\section{Che}

duced from tubers which will make from 10 t white flowers, sending forth a deliclous cInna
mon odor. Large tubers Ge each, 6 for $30 \mathrm{c}$ post pald.
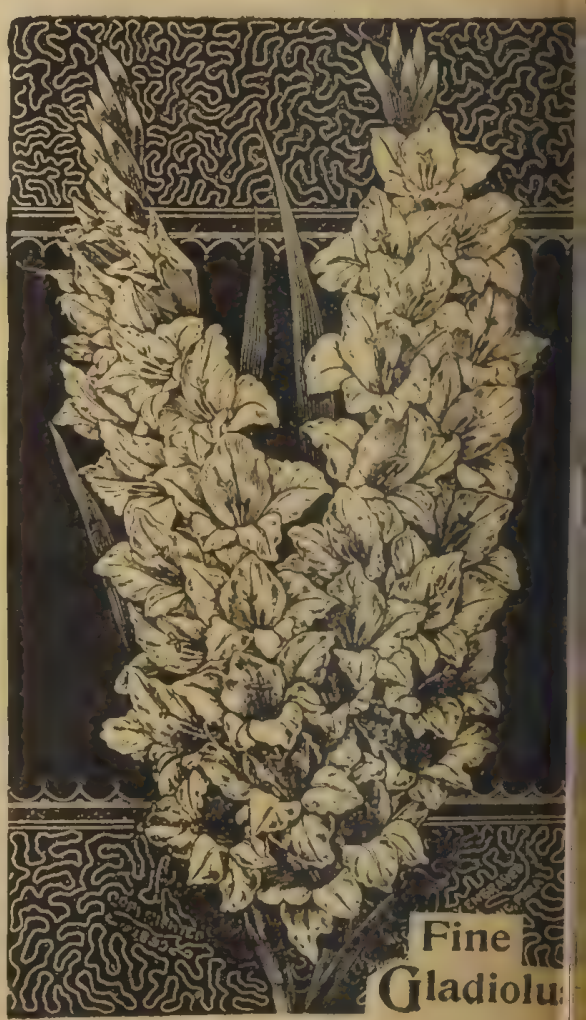


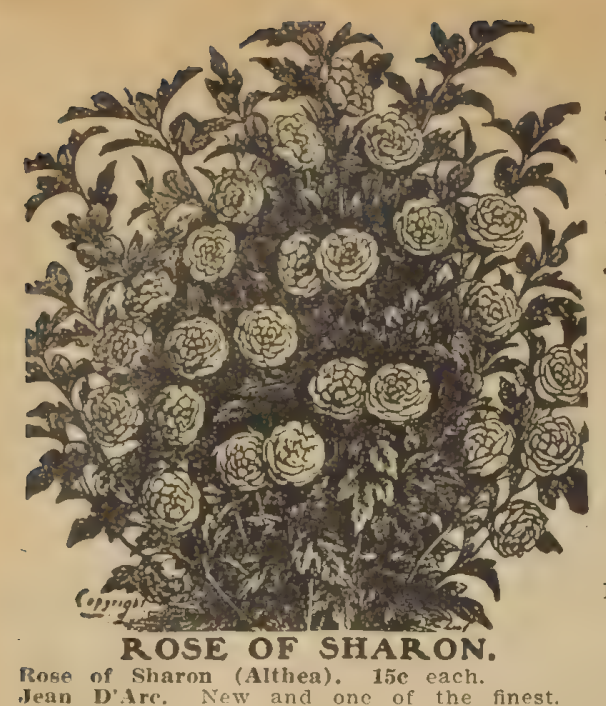

Jean D'ire.

Double Red.

Double Variegated.

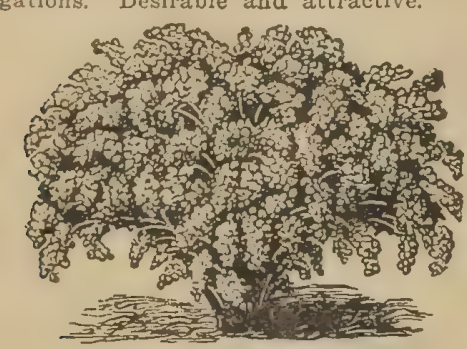

Spiræa (Bridal Wreath). STIREAS.

Anthony Waterer. The pink spirea. Forms

round compact bush 18 inches high.

Van Houttei.

and borne

Flowers white and double like little roses,

Any of the above, $25 \mathrm{se}$, each, 3 for $60 \mathrm{c}$.

\section{HARDY CLEMATIS}

The most popular climbing plant of the day, and is constantly growing in popularity-and why should it not?-as it is hardy, standing most severe winters with hut slight prowapidy and blooms freely durine Jackmanit.

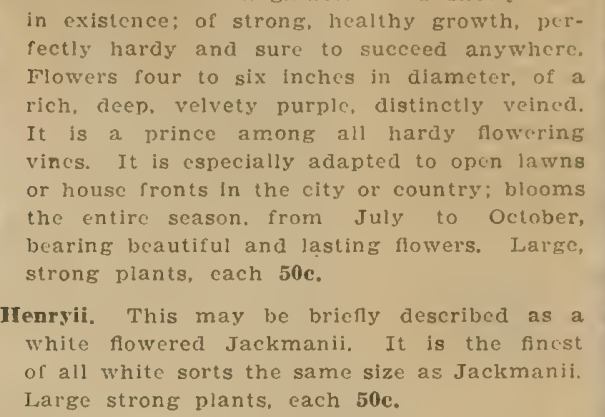

Mad Edouard Andre. An entirely distinct and proach to bright red ever sent out. Has the same vigorous growth, hardiness and freedom
of bloom as the above, while the color is a
pleasing carmine red. Large, strong plant, paniculata. This small-flowered varicty of Clcmatis is one of our most beautiful, hardy, pure snow-white, are produced in immense
clusters, farly covering the plant with a
mass of fleecy white. They have a dclicious
fragrance, The plant is of extreme rapidity
of growth. Large extra strong plants, 30c. Rudbeckia. The beautiful Golden Glow. Finest strong plants, bloom first season, 15 c each, for $25 \mathrm{c}$.

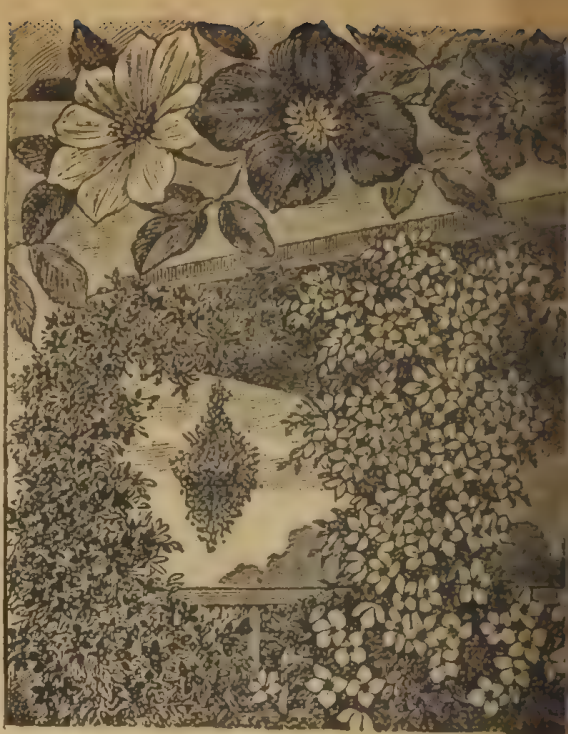

Clematio.

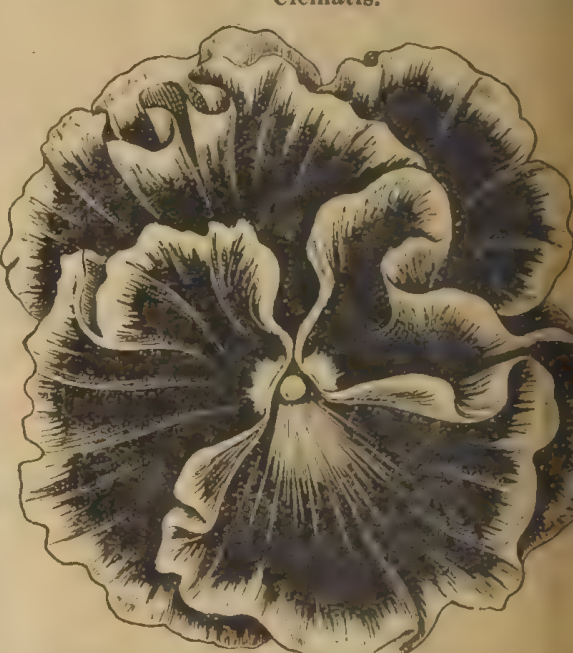

PANSY PLANTS, 20c DOZEN.

\section{Bulbs for Fall Planting}

Send in your order today so we can reserve choice stocks for you. We ship September 1 st to December 1st

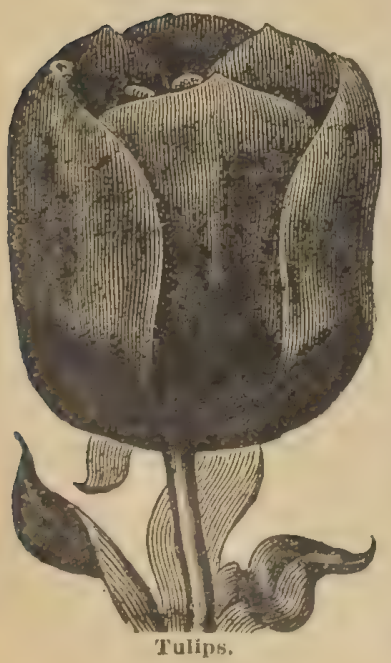

STNGLE TULIPS.

Duchesse de Parma, orange-red, with yella Reine, white, rose shaded.
I'ink lseauty, cxquisite deep pink, flushed. Yellow Prince, golden, yellow.

Crimson King, crimson scarlet.

Price, single tulips, 3e each, 30e dozen. DOCBLE TULIPS.

La Candeur, pure white.

Le Blason, rose and white.

Titian deep

Dur von Thol, scarlet.

Purple Crown, dark purnlish red color

Crown of Gold, yellow, shaced 35 dozen.

CHOICE CROCCS.

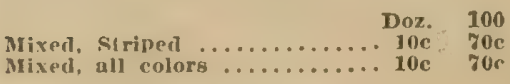

\section{JONQUTLS.}

Double, yeliow, sweet scented....3e Dach Doz. single, yellow, sweet scented....2 $17 \mathrm{c}$
Large stronf plants from choicest named sorts, among th

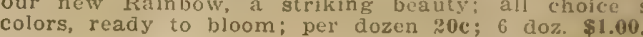

Chinese Sacred Lily. Water Falry Flower. Joss Flower. Put in a bowl filled with pebbles, setting the bulb so that it will be held firmly in place, then fill with water and place in a warm sunny window where it will grow rapidly, and proauce an abundance of deliciously fragrant white blossoms with a yclfrom time of plarting. Fach lase.

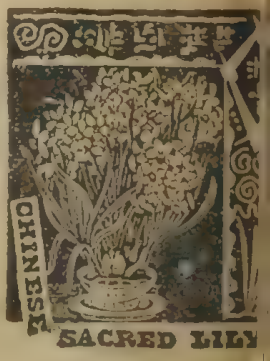

SINGIE IIYICINTHS.

Single Pure White

Single Red ..........

single Rose

Single IBlue

Single Yellow

Single, all colors, mixed.

\section{DOEHIE INACINTUS.}

Double I'ure Whito

Double Red

Double Rose

Double Rlue

Douile Yellow

Double, all colors, mixed

NARCISSIS OR DAFTODILS. SIr 3e each, 25e dozen. Double, 3e 


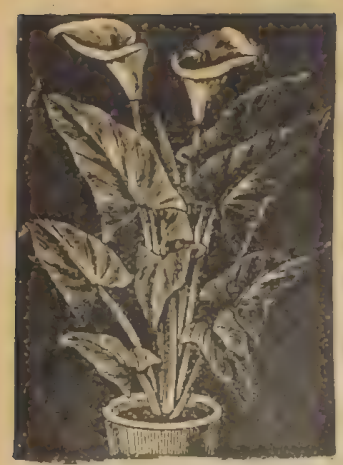

Carla limies. 10c Each.

\section{Calla Lily.}

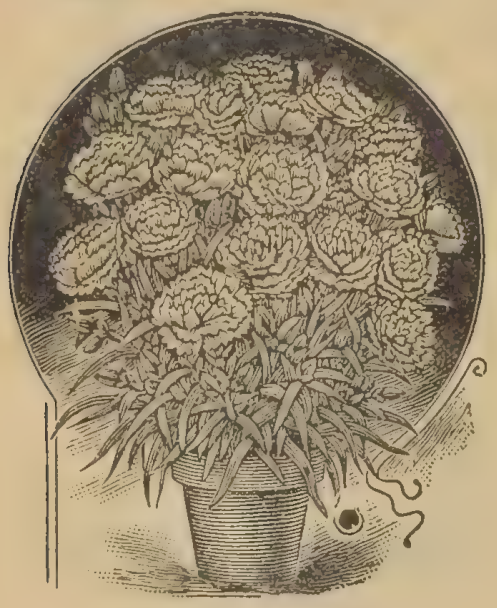

CARNATMONS 10c Each.

Very fragrant flowering plants, fine for bed

Mrs, Thomas Lawsen, pink.

Enchantress, shell plnk.

Estelle, bright scarlct.

Prosperity,

Mrs, Joost, bright shining pink.

Dorothy Whitney, deep golden yellow, light

o. P. Bassett, scarlet; rich and glowing.

White Enchantress,

White Perfection, best pure white.

CUPIIEA IPlatycentra, 8 e Fach.

either for ealled "Cigar Plant," Very fine

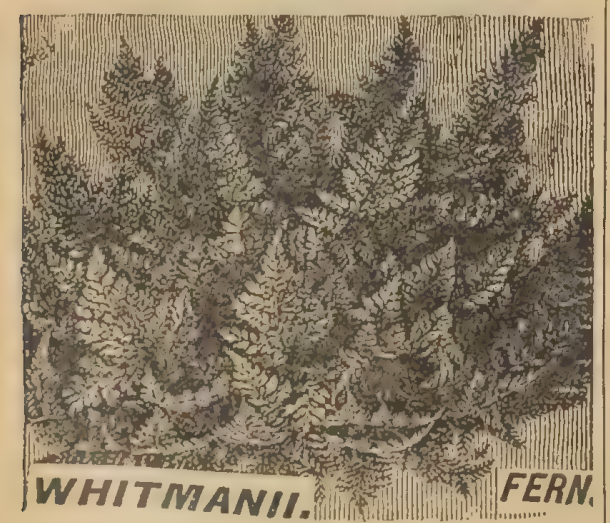

JERNS.

Whitmanii, or New Ostrich Plume.

Scotil, short bushy fine pot furn, $10 \mathrm{c}$.

Ihersonil, fringed, lisc

Boston or Sword, 10c.

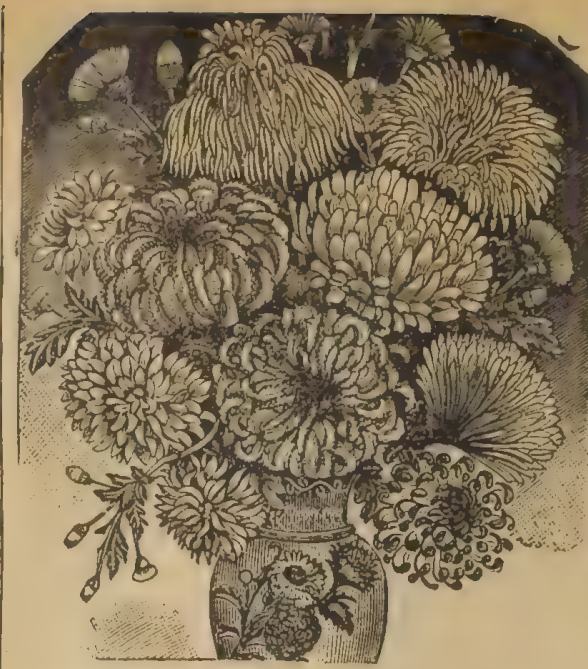

CHRISANTHEMUMS, 10c Each. 3 for 25c. 6 for $48 \mathrm{c}$.

The chrysanthemums, owing to thelr easy
culture, gorgeousness of color and free llowering

Iongolian Irince, bronze.

Harry Parr, early, large, yellow.

Maj. Bonnifon, late, large, yellow.

Iaud Dean, late, pink.

Silver Wedding, late, white.

Mrs. Henry Robinson, pure white.

Intensity, dec v velvety crimson.

Robert Halliday, early, yellow, large flower

Clementine Touset, early, large, white.

Child of Two Worlds, white Ostrich Plum

Mrs. Higinbotham, bright pink Ostrich Plum

Lavender Queen, immense solid flower,

petals erect, soft silvery lavender pink.

creamy white with long, drooping florets,

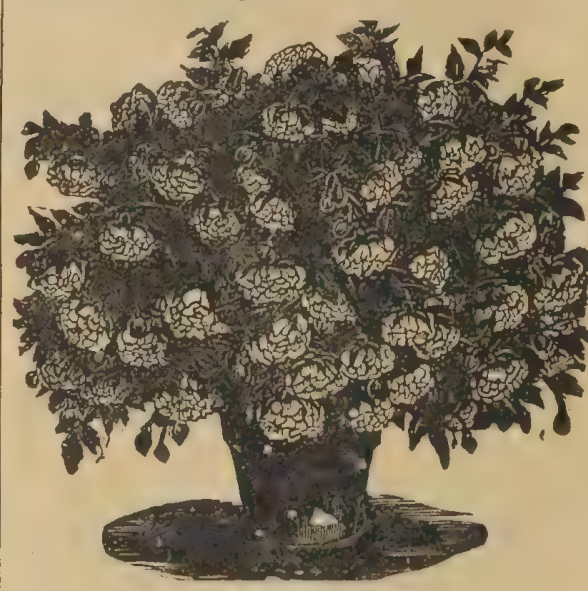

Storm King. A new superb Fuchsia of $\mathrm{ex}$ traordinary qualities. It is of somewhat drooping hablt with enormous double whit
flowers. For winter blooming it cannot b flowers. For winter blooming it cannot
surpassed. By mal!, 15c each, 4 for $50 \mathrm{c}$.

Double FCCISIAS, $10 \mathrm{c}$ Each, 3 for $25 \mathrm{c}$.

Mrs. I. G. Hill, sepals crimson, white corolla. Elm City, double purple,
Monatrona Superba, double white, large.

I'urple P'rince, biue corolla scpais scarlet.

lblack I'rince, corolla, a redalsh rose, sepals Plienomenal, thls is the larfest Fuchsla grown, red tube and sepais, Inmense bricht violet

Molesworth, free blooming whlte.

Single FuCISIA, 10c Each, 3 for 25c,

Elegant flowering, of hardy, rapld growth. islack Prince, corolla, a reddish rose, sepals Arabella, bright red and white,
GEIRINLMS.

We have improved our list of Geranlumg adding several new and valuable varletres that the llst we now offer fs as nesrly com plete as can be had.

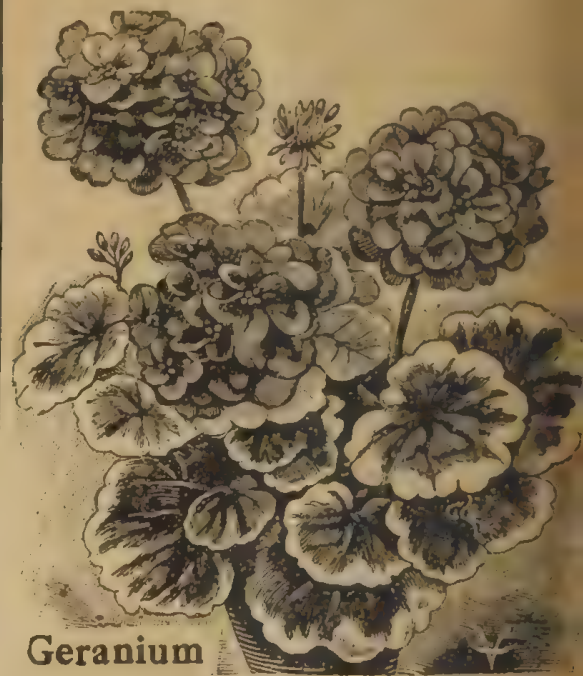

Double Geraniums, $10 \mathrm{c}$ Each, 3 for 25c, 6 for $48 \mathrm{c}$

L. Sollel, deep velvety red.

Lo Gaulois, delicate pink and white.

Jean Viaud, new rosy, with white center.

John Doyle, scarlet.

Marvel, dark red.

Madam Barney, rose.

La France, white.

Fiancee, dwarf white.

Queen of the Fuiries, salmon center, white

Frances Perkins, bright pink.

James Vick, salmon, very large.

S. A. Nut, very dark crimson.

Alphonse Ricard, brllliant orange red, flne bed Gilded Gold, deep golden orange.

Single Geraniums, 10c Fach, 3 for $25 \mathrm{c}$, 6 for 48 Star Spangled Banner, large truss, single fowe color red, white and blue, 10e each. Mar8, deep rose.

Athlete, brightest scarlet.

Madonna, pale pink, large truss.

Marguerite de Layre, the finest single pus white.

Beaute Poltevine, salmon

\section{SPECIAL OFFER}

15 PLANTS Geraniums, Double

Variegated GERANIUMS, 10c Each.

('rystal Palace fem, yellow and green.

Happy Thought, yellow center, green edg

Mrs. Pollock, varlegated.

Mountain of Snow, sllver edge.

Madam, Salleroi, bright green, sllver "dge. Scented GERANILMS, $10 \mathrm{c}$ Each. Skeleton, Rose Lear.

Ivy-Leaved GERANITMS, 10e Each. Gabilee, Hoht pink.

Eden irarchil, double, salmon color.

Chas. Monselet, flery red.

Jonn of Arc, double, pure white.

PELAIRGONICMS or Lady Washington Pan Geraniums, 13c Each.

Dorothy, rosy salmon with dark center.

Victor, flowers bright cherry red, with white base.

Caut. Ralkes, large brillant, crimson flowert. Kingston Beauty, large, pure white, with be tiful plum colored certer.
Mrs. R. Sandiford, large, double pure wh 
FETEREW, 8c Each.

ille Gem, double pure white. This is one of 120. most popular free flowering plants.

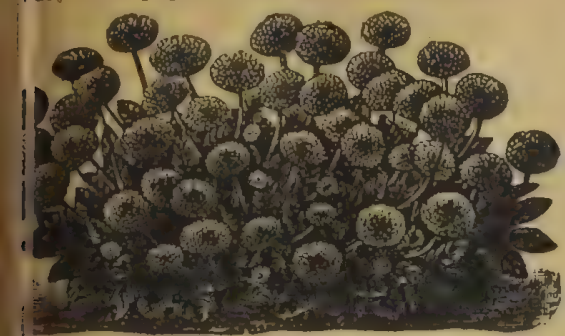

ble DAISIES, mixed colors, strong plants, 0 cents per dozen.

PARIS DAISY or Marguerite, 10c Each. dam Gailbert, white.

llle de Or, yellow.

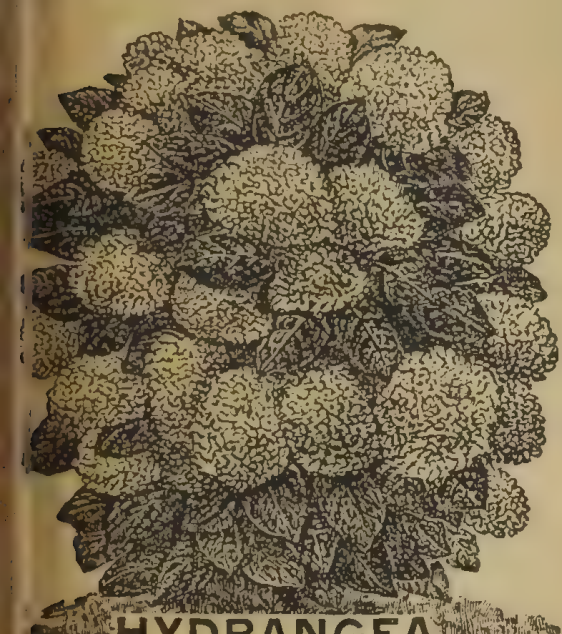

\section{HYDRANGEA, 15c Each.}

These are very desirable decorative plants; ioduce large heads of bloom in great profu-

I irtensis, produce large pink fowers. tomme pink white flowers, I aksa, deep rose pink.

Imiculata, Grandifora, hardy opening to full white and changing to deep red, $25 \mathrm{c}$, each.

HELIOTROPE, 10c Each; 3 for $25 \mathrm{c}$.

lac Queen, flowers lavender.

isg Nightingale, a lovely purple.

gdam Do Blonay, a beautiful, large white.

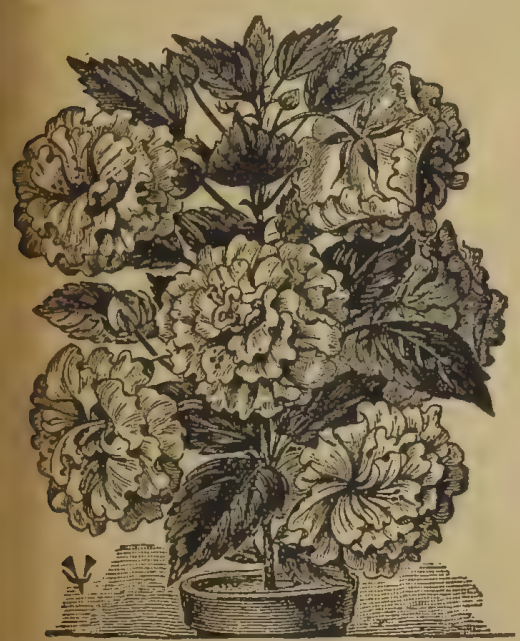

HIBISCUS, 15c Each.

Peach Blow. A rapla erect grower, immense uble flowers of a bright rich pink, with crimcenter, very fragrant. Leaves of a bright ant.

Vergicolor. Bright red, large single flowers, ntped with white; very striking.

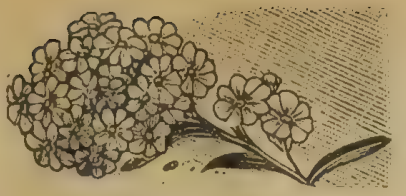

FORGE' ME-NOT.

IMPATIENS SULTANA, 10c Each.

Beautiful plants, elther as winter flowerin or summer bedding. Brilliant, rosy. scarlet flowers always in bloom.

\section{IVY, 10c. Each.}

English, plain.

German, a fast growing sort.

Boston, hardy, will cling to house and stone walls.

\section{JASMINE, 10c. Each.}

Cape Jessamine (Gardenia Florida).

A half hardy greenhouse shrub, highly valued for Its pure white rose-shaped fiowers of delicious sweetness. Its glossy ever-green foliage makes it a very decorative plant, even when not in bloom.

Maid of Orleans.-In this beautiful Jasmine there are combined some sterling qualities that place it a peer over existing sorts. Easy culture, fine grower, good bloomer, elegant fragrance, and double flowers of chaste and waxy-white appearance.

\section{JUSTICIA (Plume Plant) 15c.}

Justicia Velutina.-A new plant, adapted to pot culture or outdoor bedding. It blooms
when scarcely a few inches high. Flowers, feather and plume-like form. Color, rosy red.

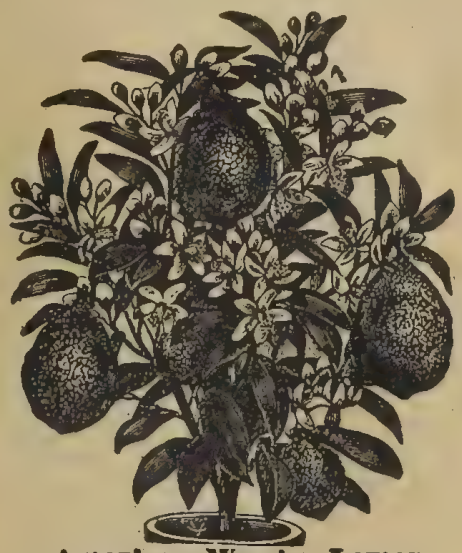

American Wonder Lomon.

AMERICAN WONDER LEMON

In this wonderful lemon we have the rich, glossy leaves like dwarf Orange. Its blos-
soms are waxy white, like a Tuberose, and as fragrant as Orange blossoms, producing fruit five times as large as the ordinary lemon. The Wonder Lemon must take a place in every good slze, each $20 \mathrm{c}$

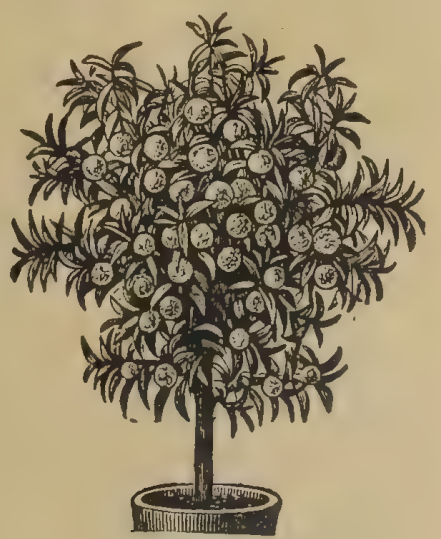

OTAHEITE ORANGE.

This is decldedly the best orange for house culture. It grows in dwart, bushy form, and Of supcrb decorative value, 20c each, postpaid.

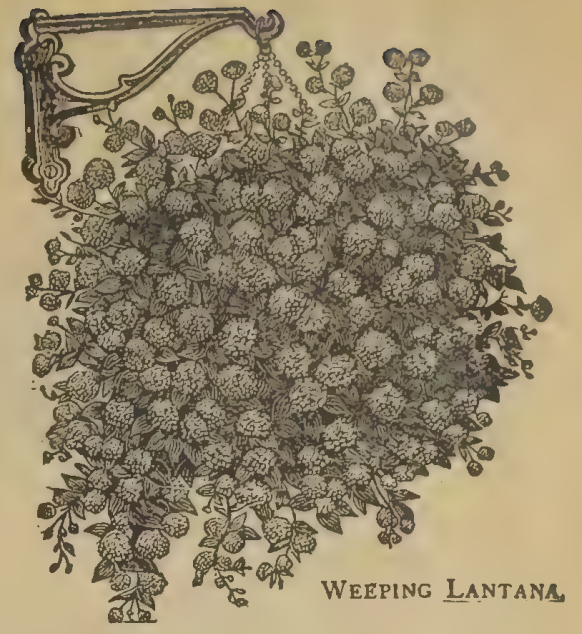

LANTANAS, 10e Each.

Weeping.-

vases, pots or open ground. Bears an

mense profusion of lovely clear pink flowers

from early summer until lat

Alba Perfecta, pure white.

La Pluto d'Or.

OLEANDERS, 10e Each.

Lillian, pure white double.

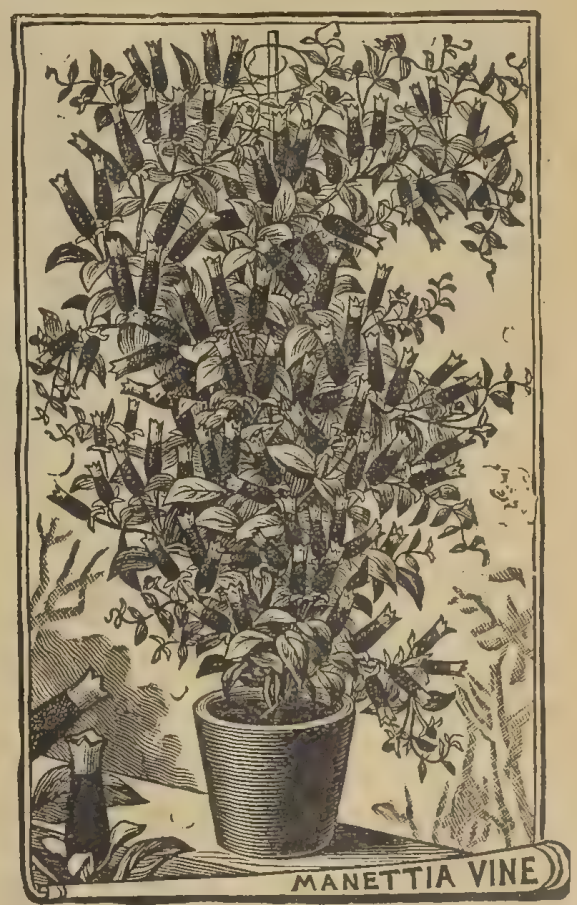

The Beautiful MANETTIA VINE.

This is the most magnificent fiowering 


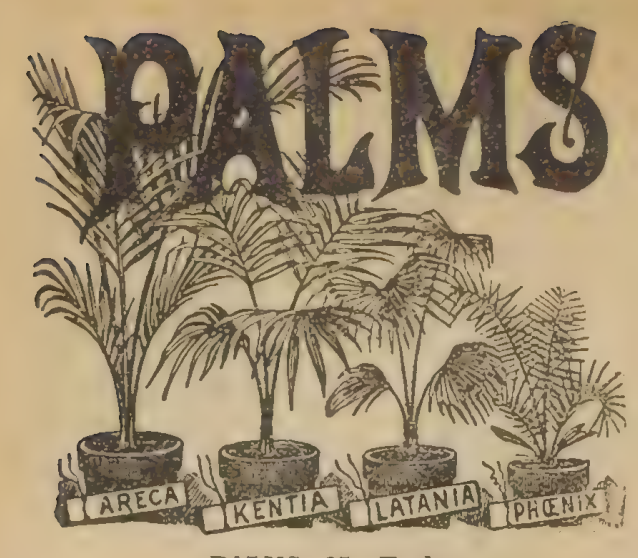

PALMS, 25c Each.

Areca Lutescens,-Glossy green leaves gracefull fully disposed.

Kentia Balmoreana.-This is, in our estimation, th that give more satisfaction all the year round.

Latania Borbonica (Fan Palm).-A beautiful Paim,

Phoenix Reclinata (Date Palm). -One of the hardiest growth, especially summer, as it stands sun and wind without damage.

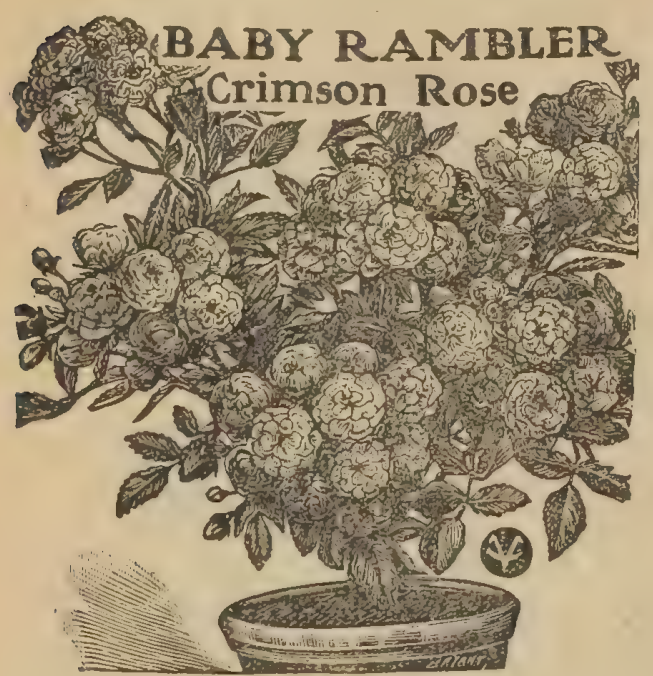

New Baby Rambler, 15e Each.

Dwarf Baby Crimson Rambler, greatest bedding and

The Four Climbing Ramblers, 15e Wach.

Pink Rambler. Yellow Rambler. Crimson liambler. White Rambler.

The four Rambiers for 50c.

Tea and Bedding ROSES, 10c Each.

Perle cles Jartion
Giolden Gate,

Nephetos,

Clothil

Bride. stan

Richs

H.MIDY ROSES, 10c Waeh.

ciafrano, yellow margin. shading to fawn.

Princess de sagan,

Hall of snow,

H.ARI) CLIMIVG ROSIES, $10 \mathrm{c}^{\circ}$ Each,

I.u Marrue,

Reine Marie Henrietta.

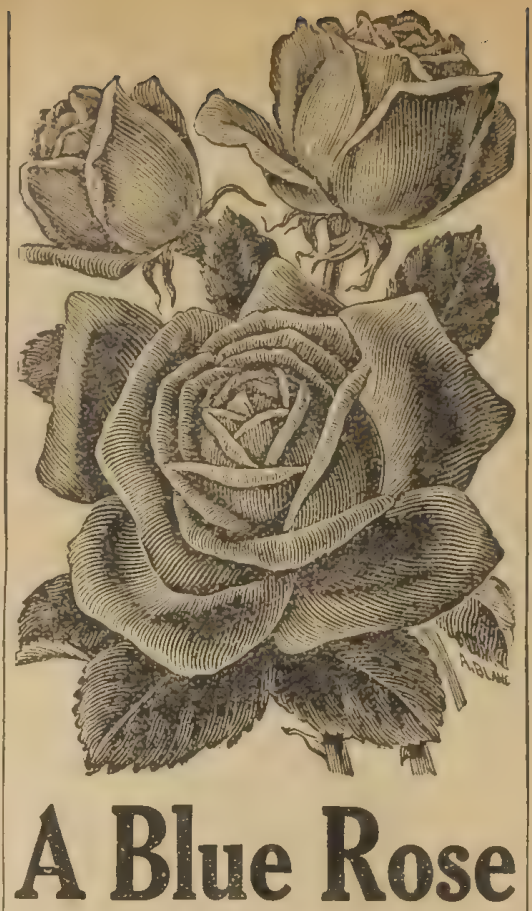

NEW BLUE RAMBLER.

Greatest Rose novelty of the century,

ner of a genuinely cornfower blue rose,
is a seedling of Crimson Rambler, very
vigorous and haray and free blooming.
Price 20c.

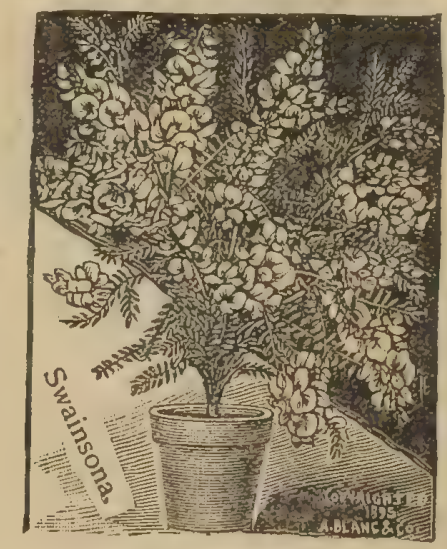

SWAINSONIA.

Galegifolia Alba. A popular house plant blooming in sprays or 10 to 20 flowers
shaped much like. Sivent Peas. A grand cverblooming plant, its pu white flowers are now used
in cut-llower work. 100 .
S.III.1X, 10c Each. A beautiful climber, largely used.

\section{S.1I.VI. 10c Each.}

A strong growlng, hardy plant, especlally fin: for bedding out, with long splkes of Bcarlel Hunfire Searlet, ver; fine.

Spleadens Scariet, flower large.

\section{VIOLETS, 10c Each.}

Marie Iouice, finegt double, lark bloe. Nwanley White, the finest double whlte.

I'rincesy of Wales, large, single, violet purp

VINCA, 10e Each.

Harisonni, green variegated

Major, white, variegated, a beautsful tralling piant.

LFMON VERBENA, 10 c Earh.

A well-known plant noted for ils dellghtful fragrance of lollage. No garden is complute without it.

VERBENA Plants, 20c Dozen.

Fine, large plants, from seed ready to bloom; mixea colors; dozen by mail, $20 \mathrm{c}$.

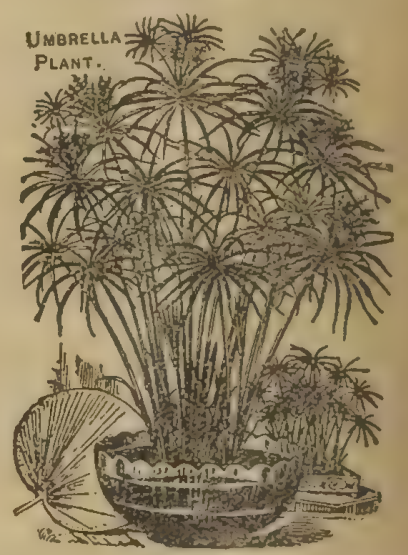

TMBRELLA PIANT (Cyperus Altenifolius) 10c. As handsome and graceful as a palm, ye of easier culture. It will grow and llourish in rooms that have only partial light.

\section{WANDERING JEW}

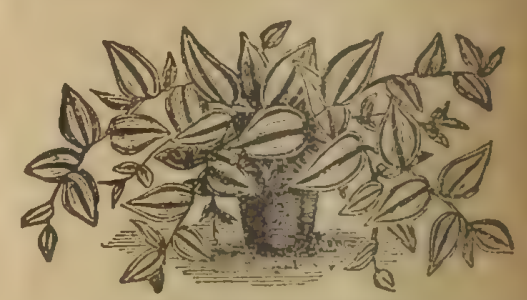

WANDERING JEW.

Tradeseantia Zelorina. Leaves highly colorec are of a grechn, variegaled with red and nurplic
Price, $8 \mathrm{e}$ cach.

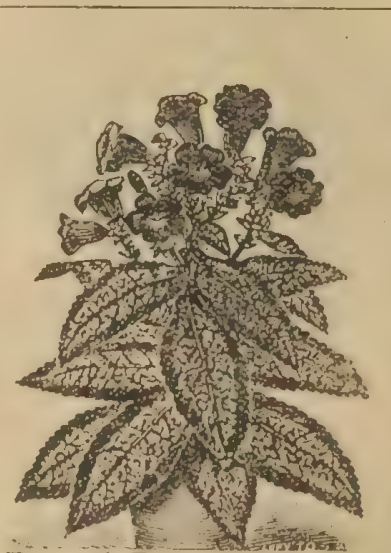

Royal Purple Plant (Strobilanthes Dyerianus)
Sirobilanthes Rosal

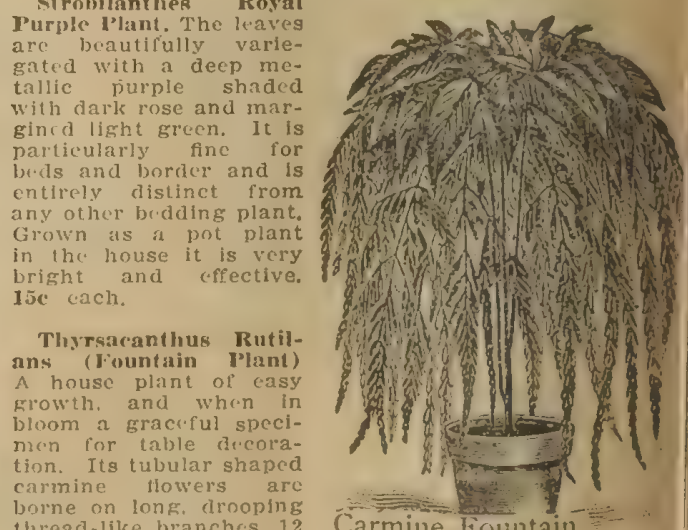

borne on long. drooping
thread-like branches, 12 to 16 inchrs in length. 


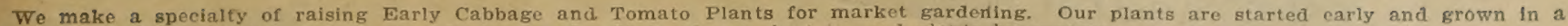

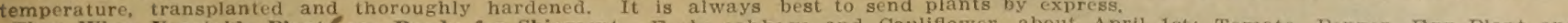
Time When Vegetable Plants are Ready for Shipment. Early cabbage and Cauliflower, about April 1

Plants quoted by Express or Freight are shipped at buyer's expense; by Mail are shipped by Post or Express paid.

\section{Early Cabbage.}

By mail-dozen, 15e, hundred roc By express, $100-1000$ I stra Sel. Jersey Wakefield, from our selected stock

larly Winningstadt

$.50 \mathrm{c} \$ 4.00$ $\begin{array}{rr}.50 \mathrm{c} & 4.00 \\ .50 \mathrm{c} & 4.00\end{array}$ Early Cauliflower.

By mall-dozen, 15e, hundred $80 \mathrm{c}$. J arly Snowball

Early Tomatoes,

By mall-dozen, 15e, hundred 70e ipark's Earliana

] ivingston's Beauty.

J warf Champion

inimson Kin

livingston's Favorite

$.65 \mathrm{c} \$ 6.00$

By mail-dozen 10c, hundred 60c.

Yellow Jersey ...................... c. \$4.00 $\quad \begin{aligned} & \text { Yellow Jersey } \\ & \text { Yellow Nansemond } \ldots \ldots \ldots \ldots \ldots \ldots \ldots \ldots \ldots \ldots \ldots \ldots \ldots \ldots\end{aligned}$ $50 \mathrm{c} 4.00$

$50 \mathrm{c} \quad 4.00$

$50 \mathrm{c} \quad 4.00$

$50 \mathrm{c} \quad 4.00$

By mail-dozen 10c, hundred 60c

Golden Self-Blanching By express, $100 \quad 1000$ White Plume Giant Pascal

By mall-dozen 15c, hundred $80 \mathrm{c}$.

Chinese Giant ..... By express, $100 \quad 1000$ ull Nose or Large Bell ......... z0e $\mathbf{6 . 0 0}$ (AIl preceding varieties transplanted

\section{Egg Plant. \\ By mall-dozen, 15e, hundred $90 \mathrm{c}$}

ew York Improved

\section{Late Cabbage. \\ Late Cabbage.}

By Express $25 \mathrm{c} \$ 2.00$

By mail-dozen, $10 \mathrm{c}$, hundred $60 \mathrm{c}$

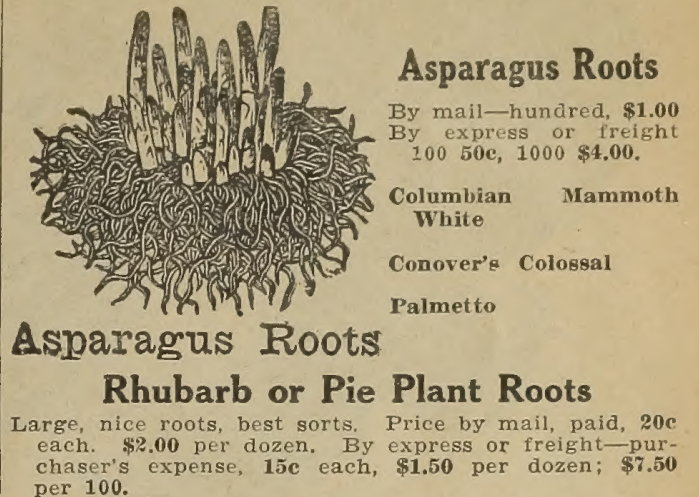

\section{SMALL FRUIT PLANTS}

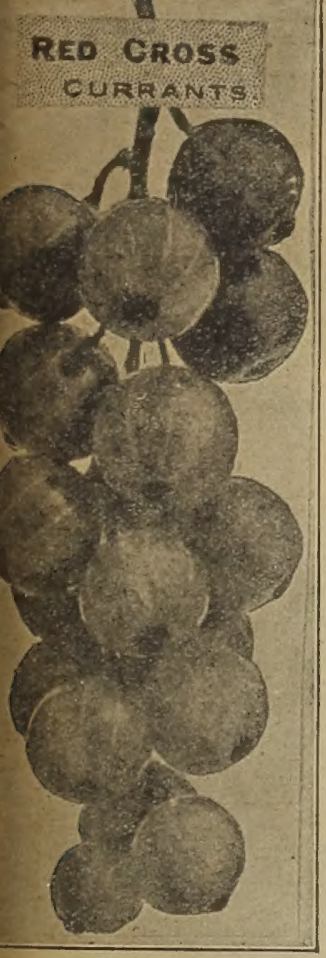

this list here

plants. Send in your order

all others are postpaid.

\section{GRAPES.}

Grapes will live and flourish dry soil, especially if made rich with barn-yard manure. vines should be trained on buildings or arbors.

Moore's Early. The bunches are large and compact, berries black. 15e each, is for $75 \mathrm{c}, 12$ for $\$ 1.25$.

Concord. One of the best old sorts; bunches and berries large, black $15 \mathrm{c}$ each, 6 for $75 \mathrm{c}, 12$ for $\$ 1.25$.

Campbell's Early. A new large, black grape: large compact bunches: pes finest quality. $20 \mathrm{c}$ each, 6 for $\$ \mathbf{\$ 1 . 0 0}$

Brighton, Color bright reddish bronze. 15c each, 6 for 75c.

Niagara. White grape of recent introduction; vine remarkably $15 \mathrm{c}$ each, 6 for $75 \mathrm{c}, 12$ for $\$ 1.25$.

\section{CURRANTS.}

Red Cross. Largest and best red sort

$15 \mathrm{c}$, dozen, $\$ 1.50$, postpaid.

Fay's Prolific. New, large, a vigorous grower; bunches very large. 15e each, 12 for $\$ 1.25$.

Victoria Red. A well known old sort; fine. $15 \mathrm{e}$ each, 12 for $\$ 1.25$. White Grape, A fine white variety. $15 \mathrm{c}$ each, 12 for $\$ 1.25$.

\section{GOOSEBERRIES.}

Indian Chief. Large, color bright red, of superior $\$ 1.50$

Downing. Hardy the standard sort,

Downing. Hardy, the standard sort, two years $95 \$ 1.00 \$ 6.00$

Houghton's Seedling. Enormously productive, isc

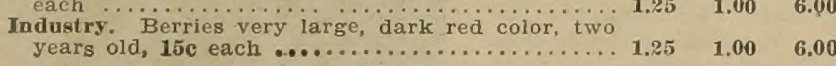
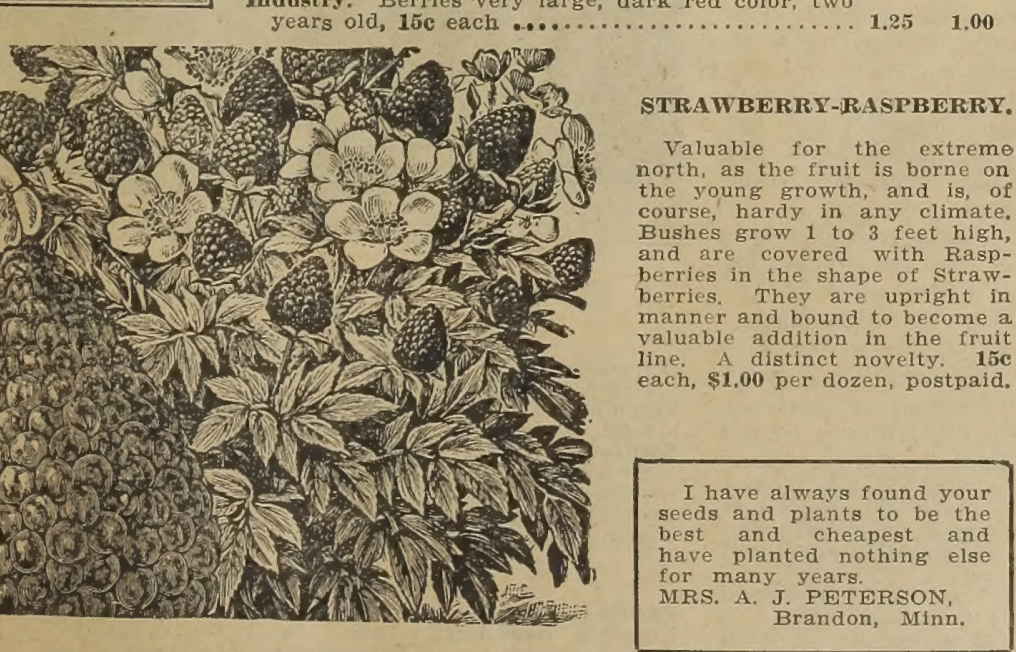

STRAWBERRY-RASPBERRY
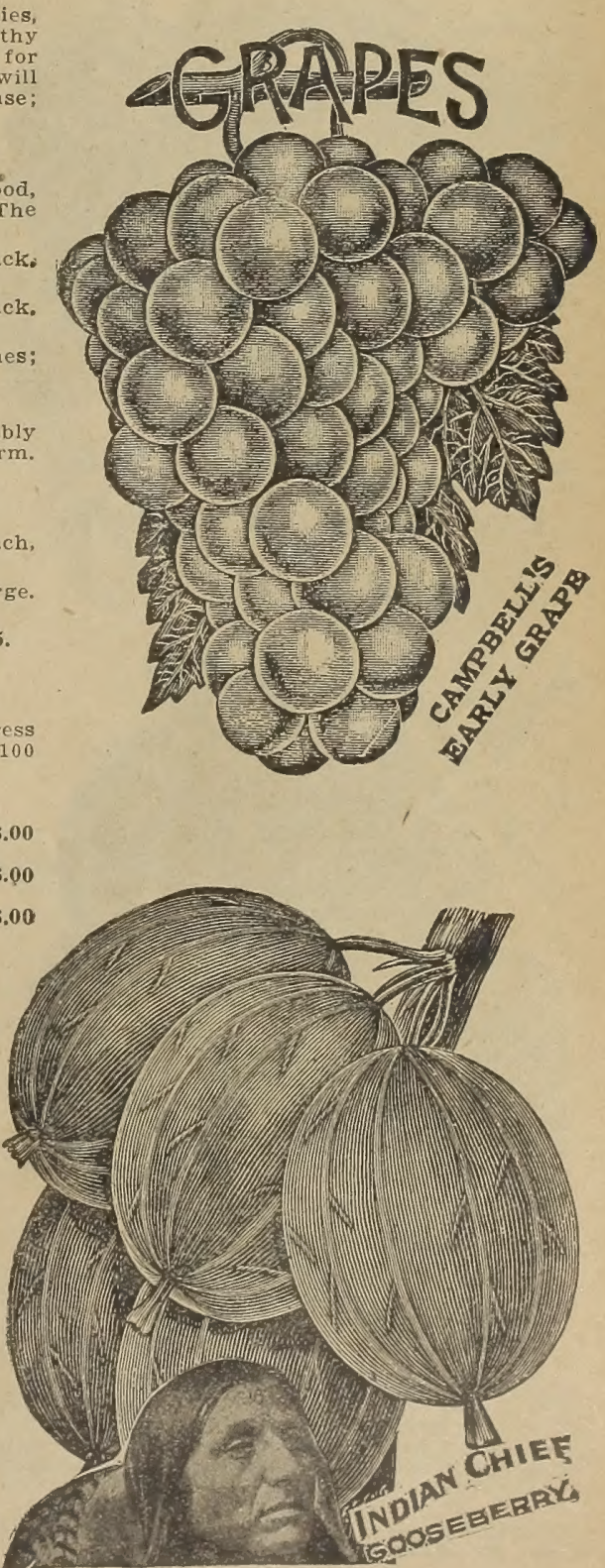


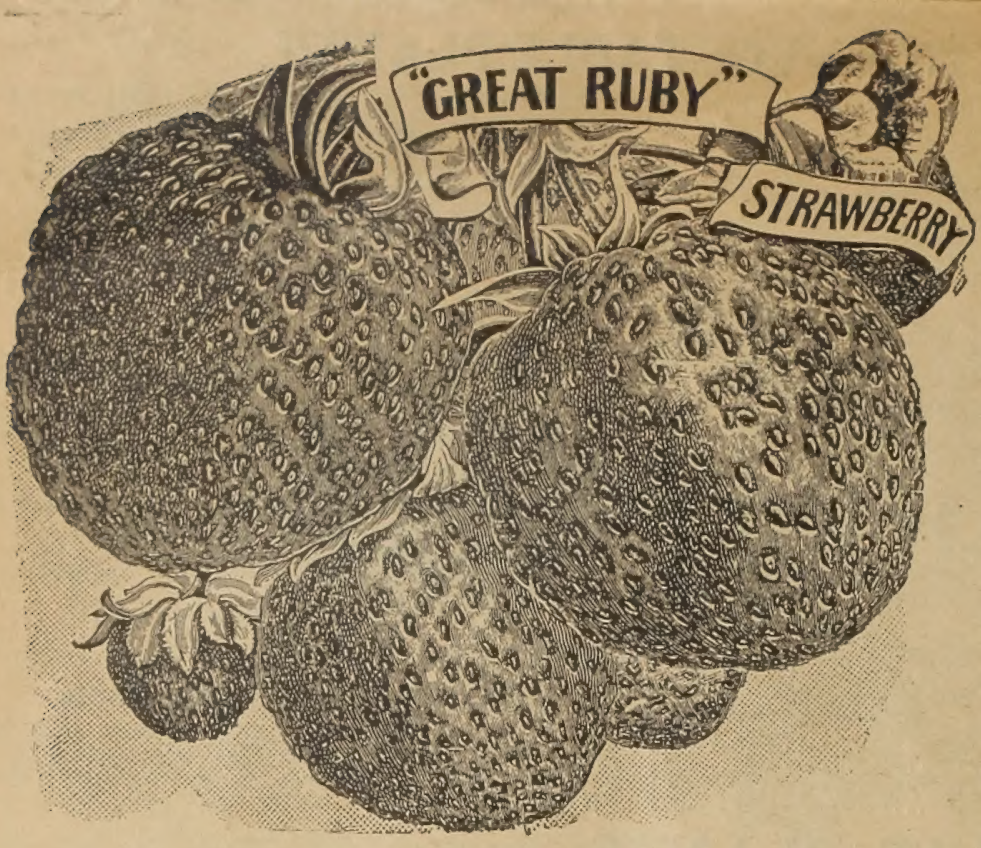

STRAWRERRTES.

Those marked (\$) are staminate or perfect blossoms, and will bear frult when set alone. Varleties marked (P) are plstlllate, and require to be ferts lized by setting every or sixth row with strong growing and perfect flowering variety.

Corsican, (S) A wonderful new sort. Vigorous grower, strong follage. Biggest and best colored berries of any sort. Great yielder. Is almost an everbearing sort. A perfect blossom sort. Price by mall, dozen 25c, 100 \$1.00. By express, buyer's expense, $10080 \mathrm{c}$

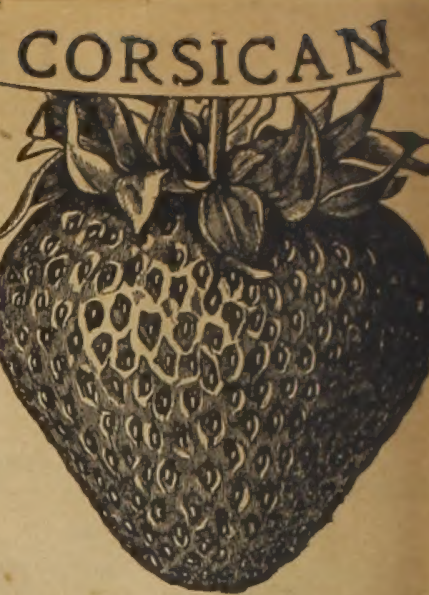

$\$ 5.00$.

Ruby, (P) This new Strawberry has proved to be on of the finest varieties ever introduced, uniformiy handsom and large, richly colored, delightfully flavored strawberry to immense size, handsome growth, remarkable productivenes son color, and, above all, the rim shape, deep lustrous crim with the and, above all, the rich luscious flavor, combine among strawberries. It commenceg to ripen kuby peeries early varleties, and bears until nearly ripen soon after th

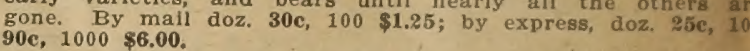
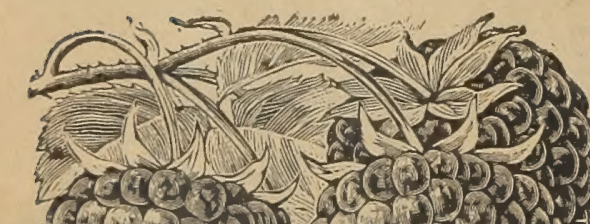

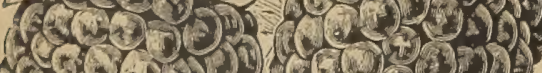
(C) $(1)-3)(10)(2)))^{3}$

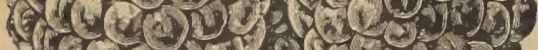

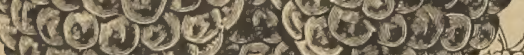

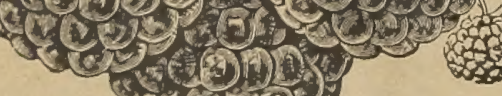
(c) $(5), 0)$

St. APnithey RED Everbearing Raspberry

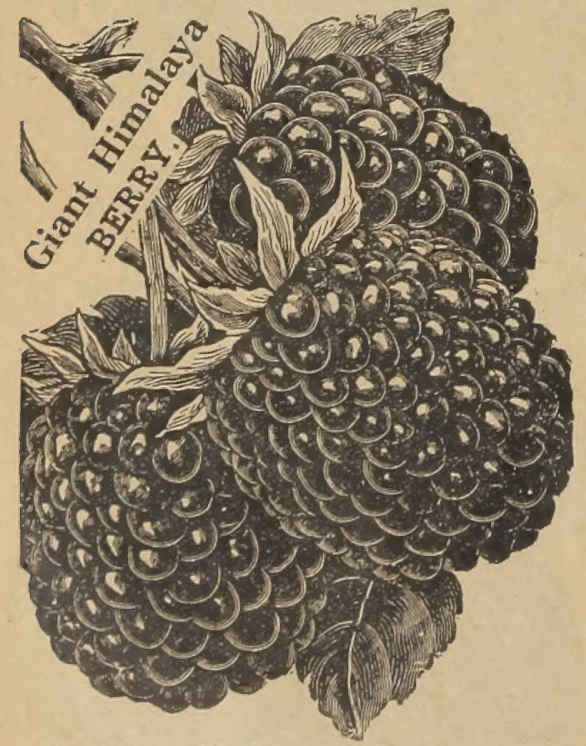

Giant Himalaya Berry Himalaya is a wonder and in a class by itself.

The Himalaya vine vine, the frult taste like a blackberry, still ure of a tree or a grape in that the wood does not die down every and blackberries but nues to bear fruit right along year after

Commencing to ripen as the Himalaya does about the first of August and continuing until October, you are sure to get a fancy price for no other berries on the market at that time.

The fruit lool's like a blackberry, being of the same shape, color and but when quallty is very good. When not quite ripe it is a little tar not infure it as it has withstood the coldest weather. growth by any means, for the crop of fruit that they will produce is 15́e, doz. \$1.30 postpaid.
Repeater Strawberry. Two erops in One Season. For several season past our attention has been called to a strawberry which made it appearance in market in September, while a bounteous crop hai been harvested from the same bed in June, same plants producin two crops in one season. The fruit is very large when well grown, glossy crimson, delicious flavor. It is a perfect blossomed sort, me dium to late. Price per dozen, 50c, postpaid.

\section{By Mall Postpaid, By Expres}

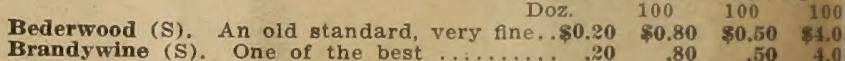

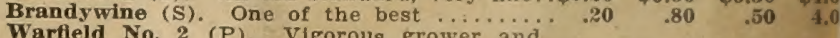
Warfield No. ${ }^{2}(P)$. Vlgorous grower and
large yielder; fine quality .................. Buster (P). Heavy cropper. New, large dark

red berry, fine quality $\ldots \ldots \ldots \ldots \ldots \ldots \ldots$
Sen

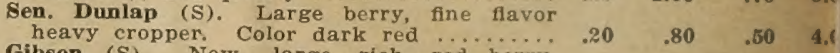

Gibson (S). New, large rich red berry,
Heavy cropper, Best shipper ........... .25 $1.00 \quad .70$

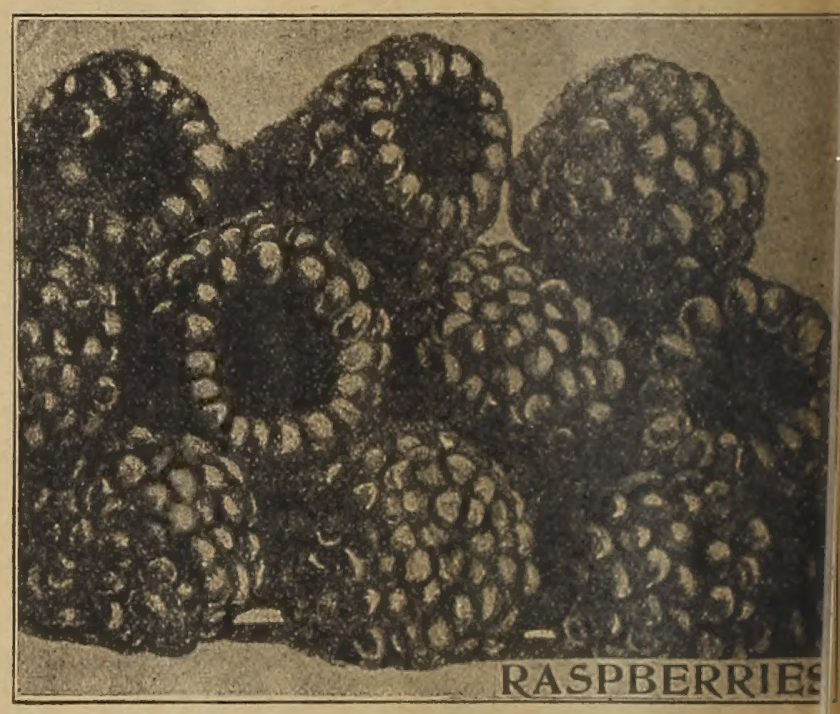

RASPBERTIES.

By Mall By Exp

Haymaker. Beautiful dark purplish-red; fruit of Doz. Doz. largest size. An enormous cropper of high quality\$0.70 \$0.60 $70 \quad 60$ Cuthbert. Large, very fine quality hardy, one of the best for famlly use, berry red ...................... Louden. A new red, extra fine sort. Large berries,

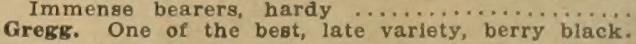
.60 $\quad .40$ $60 \quad 40$ $.600 \quad .40$ BLACKBERRTES.

Snyder. The old standard hardy, 4 for $25 c$. $.65 \quad .40$

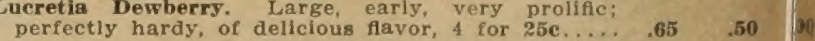


BOOKS---Horticultural

\section{POSTPAID}

Celery Culture. A practical guide fully lliustrated, 150 pages, by abbage, Cauliflower and Allied Veretables (Allen). Tells all about them, from seedtime to harvest

Cauliflowers and How to Grow them, By Brill. Paper Cover .30 Flowers, How to Grow Them (Rexford). A splendid book for beginners

jardening for Profit (Henderson). The standard work on market and family vegetable gardening

House Plants and How to Succeed with Them. A splendid book for ladies who grow plants in the house ...............00 Ifughrooms, How to Grow (Falconer). The most practical book on the subject ever written

Mushroom Culture (Robinson). An English work ...... 50

Onion Culture, the New (Grenier). Gives the latest ideas

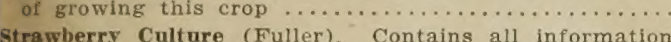
sary to enable anyone to grow their own strawberries

Successful Fruit Culture. A practical guide to the cultivation

Vegetable Gardening, the Principles of (Bailey) A highly in MONOGRAM GARDEN
CULTIVATOR.

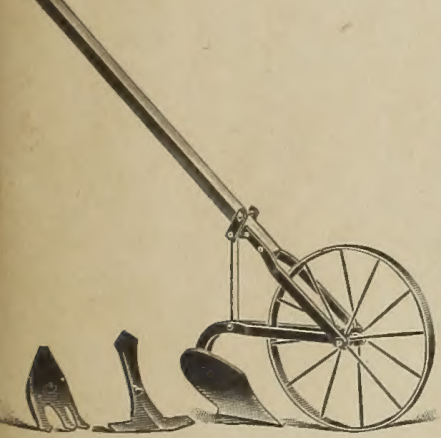

This Hand Cultivator weighs but 8 lbs. It com-

bines five tools

It is easily adjusted but slight propelling power.

Powder Bellows. Used for dustin plants with Slug Shot or like
material. By express, $\$ 1.25$.

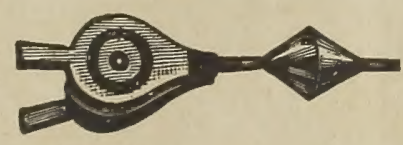

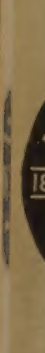

MONDS SLUG-

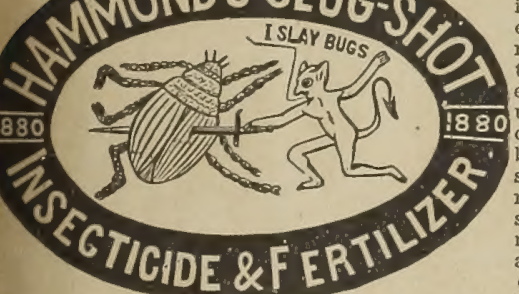

express, buyer's expense, 5 lbs. 30c; 10 lbs. 50c.

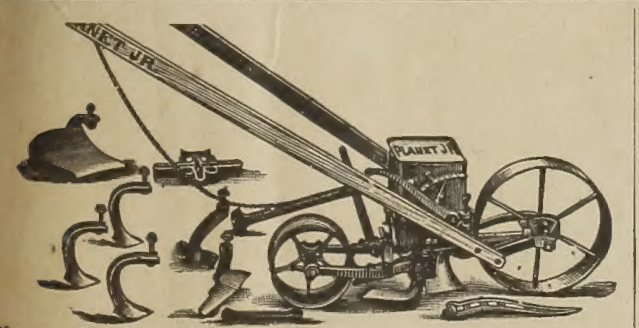

Planet Jr. No, 4. Combined Hill Dropping Drill Cultivator and Wheel Hoe, \$10.50. As a drill only, $\$ 8.50$.

Planet Jr. No. 1

Planet Jr. No, 2. Seed Drill, \$7.00.

Planet Jr. No. 8. Horse Hoe and Cultivator complete, $\$ \mathbf{8 . 5 0}$ complete, $\$ 9.00$

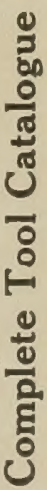

\begin{tabular}{|c|c|c|}
\hline II工IS & A Wonderful, & \\
\hline $\begin{array}{l}\text { Sulpho- } \\
\text { Tobacco } \\
\text { Soap }\end{array}$ & Inexpensive & 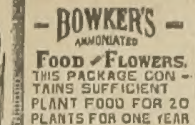 \\
\hline INSECTS & Insecticide & Q⿻ \\
\hline 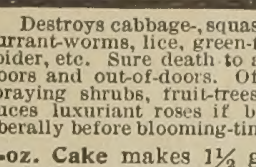 & 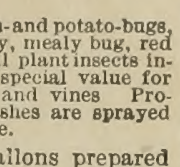 & 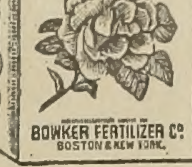 \\
\hline
\end{tabular}

owker's Foo d for Flowers,

A fertillzer made

plants grown in

house; clean,

ve odor and is

producing

solution. 10 cents. Masled, postpaid,

3=0z. Cake makes 4 gallons prepared solution. 20 cents. Mailed, postpaid, for 28 cents.

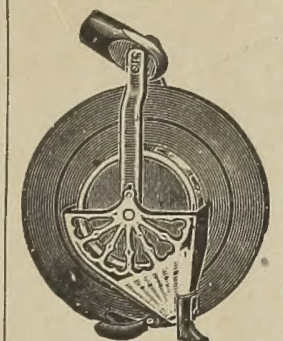

mandy

Kitchen

Bed seed How

sted in all

parts of the
United States.

\section{Plant}

40c; small pkg, postpaid, 20c.

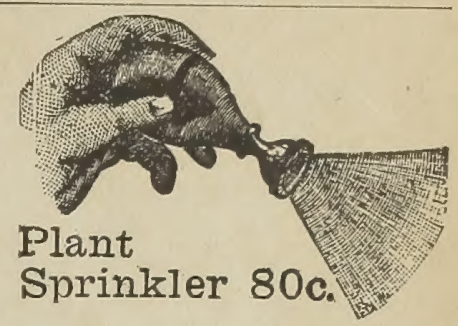

Price by ex
press, \$1.00; by

HAND

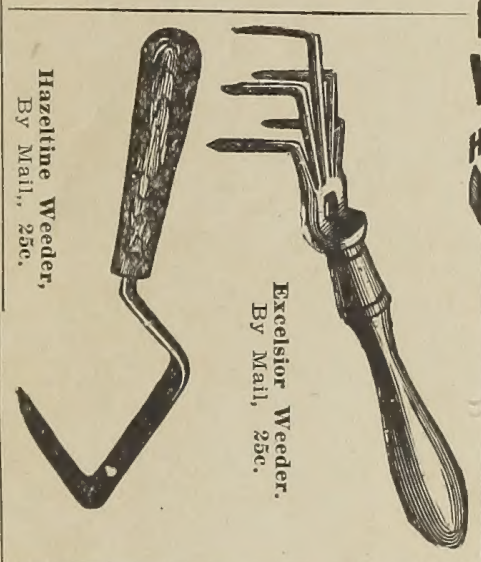

WEEDER

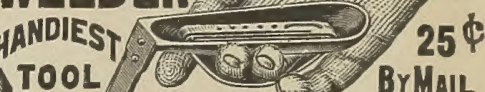

TOOL ONEARTH. PrEPAID

$25 \phi$
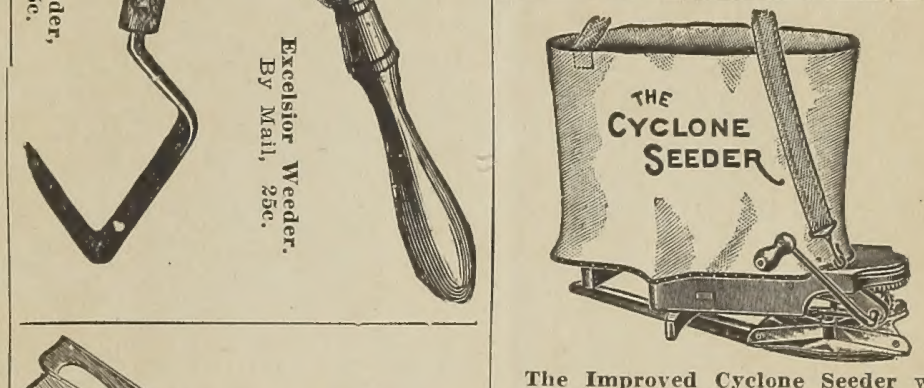

The Improved Crclone Seeder will
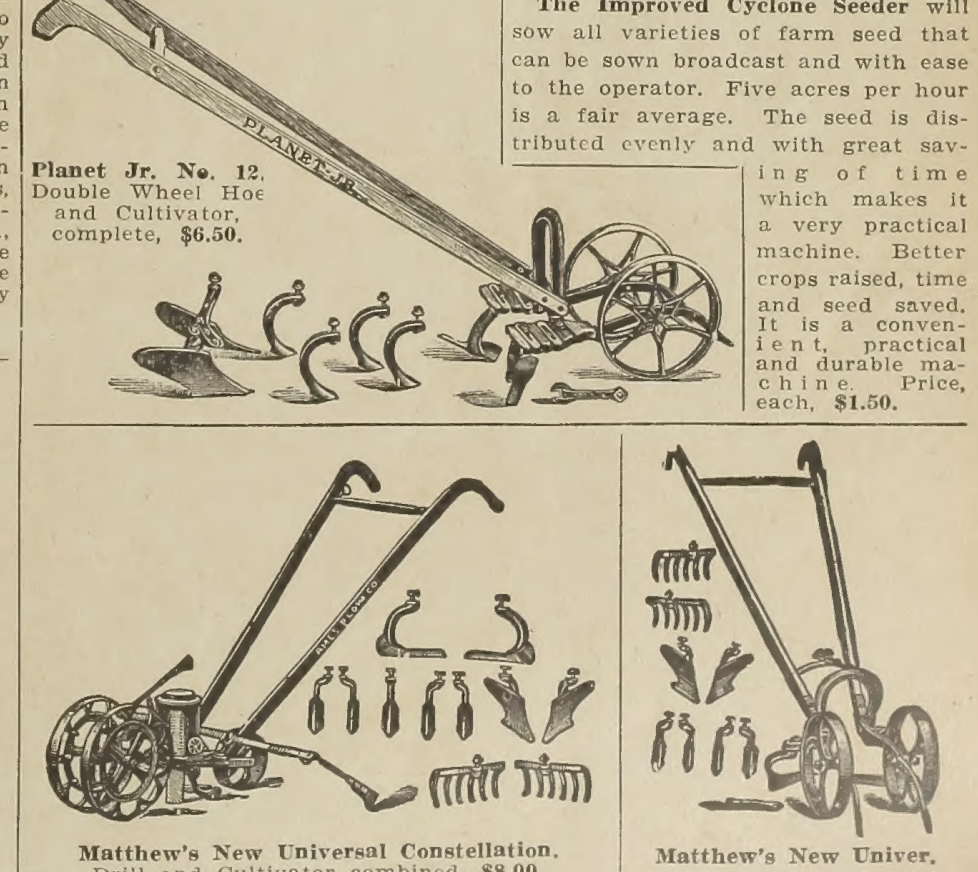

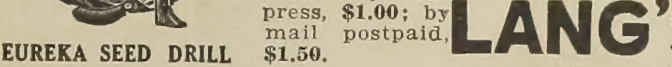




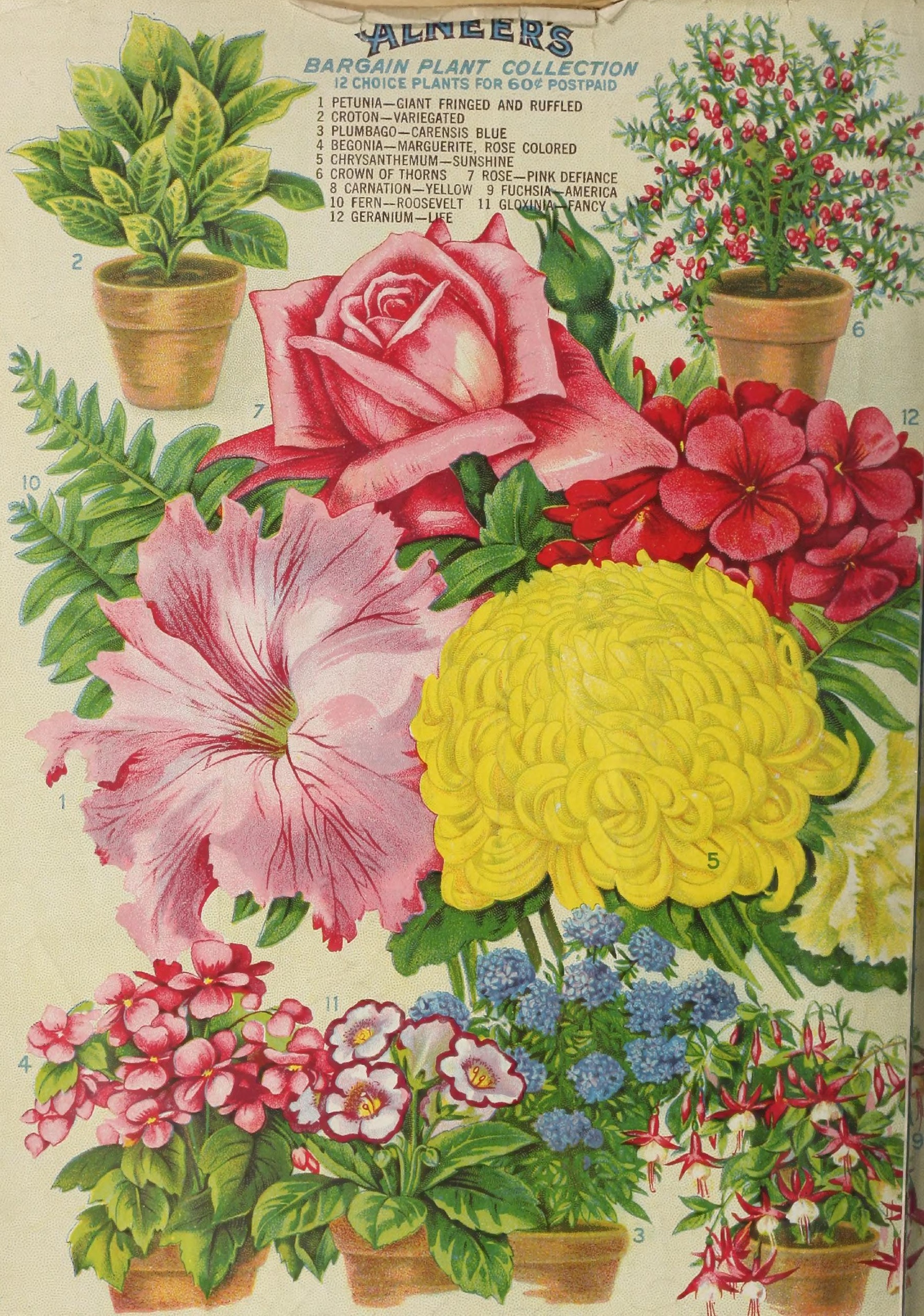

